
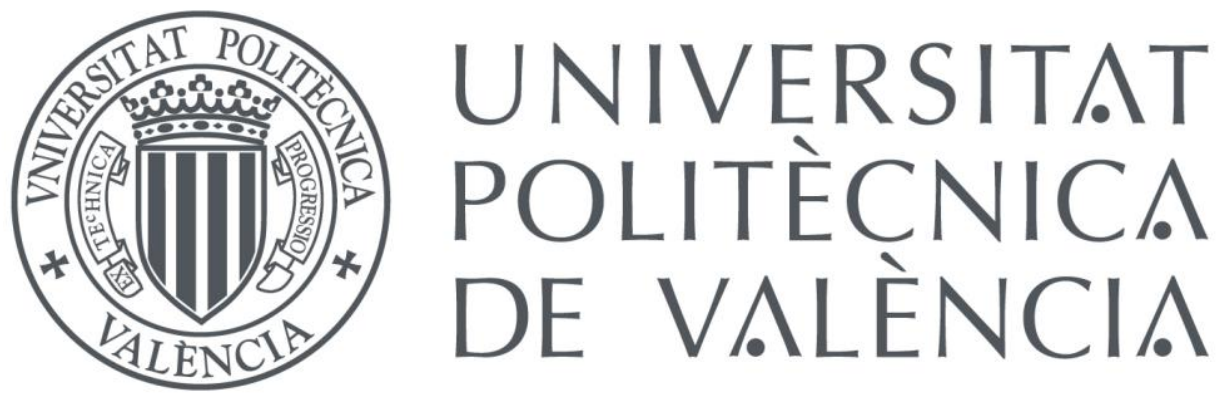

\title{
EMERGING PHOTOCHEMICAL PROCESSES INVOLVING IRON FOR WASTEWATER TREATMENT
}

Iván Matías Sciscenko

PhD Thesis

Supervisors:

Dr. Antonio Arques-Sanz

Dr. Isabel Oller-Alberola

Dr. Carlos Escudero-Oñate

September 2021
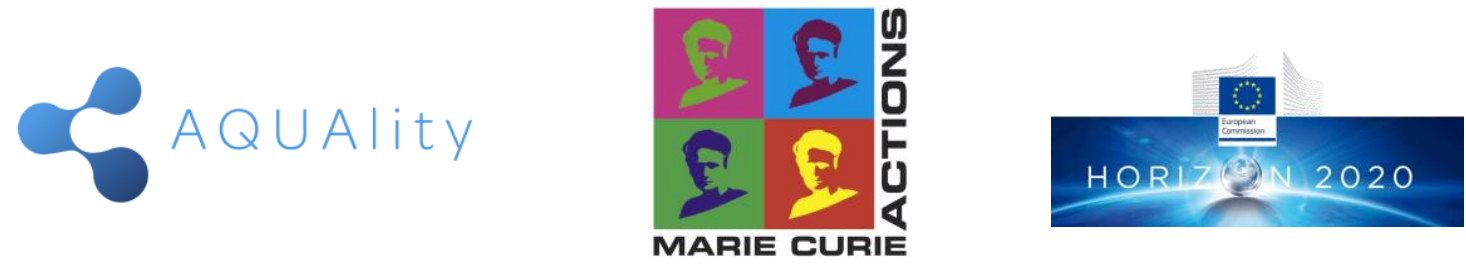



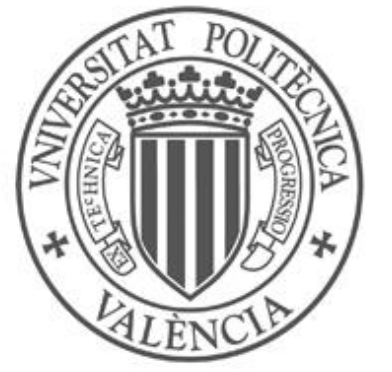

UNIVERSITAT POLITĖCNICA DE VALÈNCIA

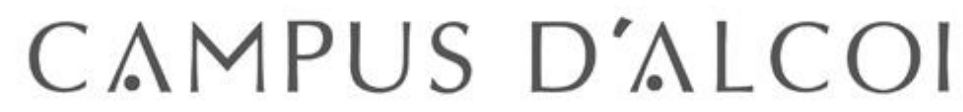

DEPARTAMENTO DE INGENIERIA TEXTIL Y PAPELERA (DITEXPA)

Emerging photochemical processes involving iron for wastewater treatment

\author{
Memory presented for the title of Doctor
}

Iván Sciscenko

PhD Thesis supervisors

Dr. Antonio Arques

Full Professor

Universitat Politècnica de València, Alcoy, Spain
Dr. Isabel Oller

Head of the Solar Treatment of Water Unit

CIEMAT-Plataforma Solar de Almería, Almería, Spain
Dr. Carlos EscuderoOñate Business Development Manager for EU Projects

Institute for Energy

Technology, Kjeller, Norway 

Sólo se pierde lo que realmente no se ha tenido ROBERTO ARLT 



\section{ACKNOWLEDGEMENTS/AGRADECIMIENTOS}

This $\mathrm{PhD}$ Thesis would not have been possible without the contributions provided, in one way or another, by many people. / Esta Tesis Doctoral no hubiera sido posible sin los aportes que prestaron, de una u otra manera, muchísimas personas.

En primer lugar, un agradecimiento eterno a mis tres directores, Antonio Arques (mi supervisor principal), Isabel Oller y Carlos Escudero-Oñate. Fue un placer haber trabajado con ustedes. Gracias por los consejos, apoyo y conocimientos transmitidos a lo largo de estos tres años. Además de ser excelentes profesionales, son también personas excepcionales.

This PhD Thesis would also not be here if not for the financing of the AQUAlity project (funded by the European Union under the Marie Skłodowska-Curie Actions - Innovative Training Networks, call: H2020-MSCA-ITN-2017, project $\mathrm{N}^{\mathrm{o}}$ 765860). Being part of it has accomplished one of the dreams of my life, performing high-quality research activities with other peers and scientists, within an interdisciplinary program, and attending to several conferences and secondments all-round the globe. Thank you to all the project members, especially to the other Early-Stage Researchers, with whom I had the good fortune of making strong bonds and share wonderful moments, particularly with Masho, Nuno, Cristina, Zsuzsanna, Dimitra, Alice, Davide, Ilaria and Dennis. Moreover, I would also like to dedicate this work to some of the many other friends made during this period: Fernando, Samira, Lucija, Morteza, Yara, Arezou, Panchi, Gulnara, Ana M., Massimo, Antonino, Irene, Alba, Ana R. and Melina.

Gracias a la Universitat Politècnica de València, donde he desarrollado la mayor parte de mi trabajo, por poner a mi disposición los laboratorios, reactivos y equipos necesarios para el correcto desarrollo de los distintos resultados aquí presentados. En particular, quiero expresar mi gratitud a las distintas personas que pertenecen a esta institución y que me han ayudado en distintas tareas, o compartido conmigo distintas experiencias: Ana Amat, Lucas Santos-Juanes, Sara García-Ballesteros, Paula García-Negueroles, Rafael Vicente, Margarita Mora, Iván Vallés, Rosa Vercher, José Bonastre, Francisco Cases, Fernanda López, Alicia Domenech, Manuel Zamorano, Inmaculada de Mora-Martí, María Ángeles Castillo y Consuelo Sabater.

An unquestionable acknowledgement to all the people who also conscientiously guided my activities during the different secondments: Francisco Valero and Javier Climent in FACSA, Gilles Mailhot and Marcello Brigante at the Université Clermont Auvergne, Sixto 
Malato and Sara Miralles-Cuevas in Plataforma Solar de Almería, and Laura Ferrando-Climent at the Institute for Energy Technology.

Por supuesto, tengo que agradecer también a la formación previa que me permitió llegar hasta aquí. Todo se lo debo a la educación de calidad, pública y gratuita, recibida tanto en la Escuela Técnica Raggio (ETR) como en la Facultad de Ciencias Exactas y Naturales (FCEN) de la bicentenaria Universidad de Buenos Aires. Gracias a todos los profesores que fueron parte de esta etapa tan determinante y con quienes estaré siempre en deuda. De todos ellos, aquel que definitivamente me marcó fue mi profesor de química en la ETR, Roberto Ojeda. Entre otras cosas, gracias por todo ese tiempo destinado a adolescentes, en horario extracurricular, preparándolos para competir en las distintas instancias de las Olimpíadas Argentinas de Química. Todo ese esfuerzo merece un reconocimiento, y lo más cercano a este es mencionarte aquí (claro ejemplo de la deuda impagable que decía anteriormente). Por supuesto, también debo agradecer a Graciela González, quien supervisó mis primeros pasos en investigación realizados en el INQUIMAE, y a todos los integrantes de la DQRA de la Comisión Nacional de Energía Atómica, sobre todo a Natalia Quici y Nahuel Montesinos, quienes fueron los primeros en introducirme en la química del hierro y sus múltiples usos para el tratamiento de aguas contaminadas.

A todos aquellos con quienes he compartido tiempo de estudio, sufrimiento y alegrías en la FCEN, especialmente a Eito, Facu, Gabo, Juli, Lauti y Lucas.

A los incorregibles de mis amigos de toda la vida, Fernando, Gari, Gastón, Machi y Nacho. Gracias por alentarme siempre en cualquier cosa que haga. Compañeros de aventuras que de ser redactadas — espero que eso nunca suceda—, superarían el largo de este trabajo.

Una mención especial se la quiero hacer llegar a Sol. Gracias por estar siempre presente para lo que sea, sin importar ni las condiciones ni la distancia. Sos una de las personas más increíbles que conocí. Es inevitable que se me dibuje una sonrisa cada vez que recuerdo alguno de los tantos momentos vividos juntos.

Nuevamente, pero con dedicación individual, a Paula y Sara (Sara y Paula). Imperdonable sería llamarlas “compañeras de laboratorio". Más que amigas, dos hermanas. Tanto ustedes como sus familias me han hecho sentir como en casa, incluso estando a miles de kilómetros de esta. No puedo expresarles, en estos pocos renglones, todo lo que llegaron a ser para mí. Gracias, porque ahora tengo un sinfín de carcajadas, viajes y anécdotas tatuadas para siempre. 
Por último, a mi familia toda, desde Buenos Aires hasta Melbourne; aunque absolutamente nada de lo que soy, ni los méritos conseguidos como este, hubieran sido posibles sin los seis integrantes principales que conformaron mis cimientos: mis tres abuelos, mi hermanito y mis padres. A la Nona y mis abuelos, Martha y Víctor, principalmente les agradezco la infancia que nos dieron (y la paciencia que nos tuvieron) a mí y a mi hermano, así como también la gran cantidad de recuerdos preciosos que me han regalado y que revivo de vez en cuando. Al mejor hermano que tengo, el Ing. Gastón Sciscenko, del cual estoy muy orgulloso - aunque jamás se lo vaya a decir a la cara-, amigo desde que tengo 2 años y contrincante predilecto en alguna que otra pelea. Y, finalmente, a mis viejos, Francisco y Viviana. Sin lugar a duda, los principales responsables de que hoy este aquí, escribiendo estas palabras en este trabajo. Gracias, entre muchas otras cosas, por enseñarme a ser exigente conmigo mismo y perseverante; por apoyarme siempre de manera incondicional, y por todo ese esfuerzo que constantemente hacen para convencerme de que puedo conseguir, dentro de lo lógico, cualquier cosa que me proponga. Los quiero y adoro muchísimo. Afortunadamente, jamás podré saldar cuentas con ustedes, porque todo lo que me dan nunca cesa. Simplemente les dedico esta Tesis Doctoral, de cuyos errores y aciertos son, claro está, inocentes. 



\section{ABSTRACT}

Being the world facing water scarcity as a global consequence of Climate Change and freshwater excessive use, smarter water management procedures (i.e. use of reclaimed water) are urgently demanded. Pharmaceuticals, pesticides, flame retardants and many other substances used in households, industries or farms, are present in urban wastewater in trace concentrations (ng $-\mu \mathrm{g} / \mathrm{L})$. These substances, denominated Contaminants of Emerging Concern (CECs) are generally non-biodegradable, exhibiting low or incomplete degradation against actual wastewater treatment plants (WWTP) technology (typically, activated sludge) ending up in the natural environment where effluents are discharged. The plausible issues associated with CECs are toxicological effects (acute and bioaccumulation) towards aquatic biota, ecosystem damage, proliferation of antibiotic-resistant bacteria, among others. In consequence, so-called Advanced Oxidation Processes (AOPs) are required to couple to WWTP to obtain the enough quality required for the future wastewater effluents directives. For this $\mathrm{PhD}$ Thesis, we have mainly focused on Fenton, (solar-)photo Fenton and zerovalent iron (ZVI) based Fenton.

Dark Fenton and photo-Fenton were employed to degrade Fluoroquinolones (FQs) (a class of synthetic antibiotics considered CEC) as model pollutants under different conditions: pH (3-8), pollutant concentration $(3-300 \mu \mathrm{M})$, number of present FQs (1, 3 and 5), and water matrix (ultra-pure, salty and simulated wastewater). Experiments were performed at bench and pilot plant scales, employing sunlight (simulated and real) and ultraviolet light irradiations. Obtained pollutant abatement rates with Fenton-related processes were compared with photolysis, heterogeneous photocatalysis and $\mathrm{H}_{2} \mathrm{O}_{2} / \mathrm{UV}$. At equal conditions, only through photo-Fenton process significant FQs mineralization were achieved. In those cases where total organic carbon had not exhibited a considerable decrease, the reason was attributed to the release of oxidation by-products.

Since FQs are fluorescent, we decided to employ fluorescence excitation-emission matrices (EEM) in combination with the chemometric tool, Parallel Factor Analysis (PARAFAC), to track their degradations. Although EEM-PARAFAC related studies are usually focused towards the characterization and monitoring of dissolved organic matter $(\mathrm{DOM})$ in natural waters and wastewater effluents (work also included in this PhD Thesis following the DOM along the different stages of a drinking water plant), it is barely the first 
time that it is used for the purposes we have here proposed. The objective is demonstrating that EEM-PARAFAC could be a feasible complementary methodology for the study of fluorescent CECs degradations, avoiding the use of expensive and sophisticated techniques (e.g mass spectrometry), not always available.

EEM-PARAFAC has demonstrated to be an economical, reagentless and non-timeconsuming way for simultaneously follow the removal of several fluorescent CECs degradation in a sample, in presence of non-calibrated interferences, and allowing to gain further insights into the by-products molecular structures. Results indicated that irradiation alone is not able to produce important changes in the FQs's core structure, in sharp contrast with (solar-photo-)Fenton, where decrease of the PARAFAC components scores associated to the FQ-like compounds were observed. Zone of inhibition assays employing E. coli showed that the antibiotic activity decreased in parallel with the overall decay of PARAFAC components related to parent pollutants and generated FQ-like by-products.

Iron is chelated by FQs, generating coordination complexes. For Enrofloxacin (ENR), one of the FQs most frequently used and detected in water bodies, it was observed that the complex with $\mathrm{Fe}^{3+}$, stoichiometry ENR: $\mathrm{Fe}^{3+}=3: 1$, was stable within a $\mathrm{pH}$ range from 3.0 to 7.5. Half-life time $\left(\mathrm{t}_{1 / 2}\right)$ of ENR alone under sun simulated conditions was around $22 \mathrm{~min}$, whereas iron complexation enhanced its photostability, leading to a $\mathrm{t}_{1 / 2}$ of $2.1 \mathrm{~h}$. Moreover, reactive oxygen species generation and formed photoproducts were also iron dependent. Noteworthy, in presence of $\mathrm{H}_{2} \mathrm{O}_{2}$, photo-Fenton takes place, being efficient even at neutral $\mathrm{pH}$, also able of enhancing the degradation of other present CECs. We have therefore confirmed that FQ-iron interaction, usually downplayed, should always be considered when performing related photo-Fenton studies. In addition, FQs photolytic rate constants were always higher at neutral $\mathrm{pH}$ for every tested compound since their zwitterionic form is the most photolabile one.

The other important aspect of the PhD Thesis was the use of ZVI-based Fenton processes. Some CECs such as nitroaromatic compounds, exhibit slow degradation rates even with AOPs. The development of new and more efficient ZVI treatment trains for pollutant degradation has been attracting great interest in the last few years. This approach consists of a first pre-treatment only with ZVI (i.e. reduction, dehalogenation), followed by a Fenton oxidation taking advantage of the released iron ions from the first step. In order to analyse the strategy's plausible advantages and potential drawbacks within wastewater treatment applications, reductive/oxidative treatment train based on commercial ZVI microparticles (mZVI) has been 
studied. The effect of the initial amount of $\mathrm{mZVI}, \mathrm{H}_{2} \mathrm{O}_{2}, \mathrm{pH}$, conductivity, anions, dissolved oxygen were analysed using p-nitrobenzoic acid (PNBA) as model pollutant. 83\% reduction of PNBA $6 \mu \mathrm{M}$ into p-aminobenzoic acid (PABA) was achieved in natural water at initial $\mathrm{pH} 3.0$ and $1.4 \mathrm{~g} / \mathrm{L}$ of mZVI under aerobic conditions in $2 \mathrm{~h}$. An evaluation of the convenience of removing mZVI after the reductive phase (before the Fenton oxidation one) was investigated together with mZVI reusability. The Fenton step against the more reactive PABA required 50 $\mathrm{mg} / \mathrm{L}$ of $\mathrm{H}_{2} \mathrm{O}_{2}$ to achieve more than $96 \%$ removal in 15 min at $\mathrm{pH} 7.5$ (final $\mathrm{pH}$ from the prereductive step). At least one complete reuse cycle (reduction/oxidation) was obtained with the separated mZVI. This approach might be interesting to treat wastewater containing pollutants initially resistant to hydroxyl radical $\left(\mathrm{HO}^{\bullet}\right)$, but easily reduced, being able to decrease its toxic load as well as increasing its reactivity for a subsequent oxidation step. 


\section{RESUMEN}

El mundo se enfrenta a la escasez de agua como consecuencia global del Cambio Climático y al uso excesivo de agua potable, por lo que se requieren, urgentemente, procedimientos de gestión de este recurso mucho más eficientes (por ej., el uso de agua recuperada). Los productos farmacéuticos, plaguicidas, retardantes de llama y muchas otras sustancias que se utilizan diariamente en hogares, industrias o granjas, están presentes en las aguas residuales urbanas en concentraciones mínimas (ng $-\mu \mathrm{g} / \mathrm{L}$ ). Estas sustancias, denominadas contaminantes de preocupación emergente (CEC), generalmente no son biodegradables, presentando una degradación baja o incompleta frente a la actual tecnología empleada en las plantas de tratamiento de aguas residuales (WWTP) (típicamente, fangos activados), y, por lo tanto, siendo luego introducidos en el medio ambiente durante la descarga de los efluentes. Los problemas asociados con los CEC pueden ser varios, como los efectos toxicológicos (agudos y de bioacumulación) hacia la biota acuática, daño al ecosistema, proliferación de bacterias resistentes a los antibióticos, entre otros. En consecuencia, los denominados Procesos de Oxidación Avanzada (AOP) deben de acoplarse a las WWTP para que el efluente tenga la calidad suficiente requerida en vistas de las futuras directivas de aguas residuales. Para este trabajo, nos hemos centrado, principalmente, en procesos Fenton, fotoFenton(-solar) y Fenton basado en hierro cero-valente (ZVI).

Los procesos (foto-)Fenton fueron empleados para degradar fluoroquinolonas (FQ) (una clase de antibióticos sintéticos considerados CEC) como contaminantes modelo en diferentes condiciones: $\mathrm{pH}(3-8)$, concentración de contaminante $(3-300 \mu \mathrm{M})$, número de FQ presentes (1, 3 y 5), y matrices de agua (agua ultrapura, salina y de WWTP simulada). Los experimentos se realizaron a escala banco y planta piloto, empleando luz solar (simulada y real) e irradiaciones con luz ultravioleta. Las velocidades de degradación de los contaminantes obtenidas con procesos tipo-Fenton se compararon con las análogas de fotólisis, fotocatálisis heterogénea y $\mathrm{H}_{2} \mathrm{O}_{2} / \mathrm{UV}$. En igualdad de condiciones, solo a través del proceso foto-Fenton se logró una mineralización significativa de las FQs. En aquellos casos en los que el carbono orgánico total no mostró una disminución considerable, la razón se atribuye a la liberación de subproductos de oxidación.

Dado que las FQ son fluorescentes, decidimos emplear matrices de excitación-emisión de fluorescencia (EEM) en combinación con la herramienta quimiométrica, análisis paralelo 
de factores (PARAFAC) para estudiar sus degradaciones. Si bien la metodología EEMPARAFAC es utilizada mayoritariamente dentro de la caracterización y seguimiento de materia orgánica disuelta (DOM) en aguas naturales y efluentes (trabajo también incluido dentro de la Tesis Doctoral para el seguimiento de la DOM en las distintas etapas de una planta de agua potable), es apenas la primera vez que es utilizada para los fines que hemos aquí propuesto. El objetivo es demostrar que EEM-PARAFAC podría ser una metodología complementaria factible para el estudio de degradaciones de CECs fluorescentes, evitando así el uso de técnicas costosas y sofisticadas (por ejemplo, espectrometría de masas), no siempre disponibles.

EEM-PARAFAC ha demostrado ser una técnica económica, veloz y que no requiere del uso de reactivos, para seguir simultáneamente la eliminación de la degradación de hasta 5 FQs fluorescentes presentes en una misma muestra, en presencia de interferencias sin calibrar, y obtener información sobre las posibles estructuras moleculares de los intermediarios de reacción. Los resultados indicaron que la fotólisis por sí sola no es capaz de producir cambios importantes en la estructura de las FQs, mientras que con (foto-)Fenton sí que se observó una notable disminución de los scores de los componentes PARAFAC asociados con los compuestos del tipo FQ. Los ensayos de zona de inhibición empleando E. coli mostraron que la actividad antibiótica disminuyó en paralelo con la desintegración de todos los componentes PARAFAC relacionados con las FQs y subproductos similares a estas.

El hierro interacciona con las FQ formando complejos de coordinación. Para la enrofloxacina (ENR), una de las FQ más utilizadas y frecuentes en aguas, se observó que se forma un complejo estable en un rango de $\mathrm{pH}$ desde 3.0 a 7.5 con $\mathrm{Fe}^{3+}$, con estequiometría ENR: $\mathrm{Fe}^{3+}=3: 1$. El tiempo de vida media $\left(\mathrm{t}_{1 / 2}\right)$ de ENR sola bajo irradiación solar simulada, fue de alrededor de $22 \mathrm{~min}$, y al estar coordinando al hierro, su fotoestabilidad aumentó, lo que llevó a un $\mathrm{t}_{1 / 2}$ de 2,1 h. Además, la generación de especies oxígeno reactivo y los intermediarios de reacción formados también fueron dependientes del hierro. En presencia de $\mathrm{H}_{2} \mathrm{O}_{2}$, ocurre el proceso foto-Fenton, el cual fue eficaz incluso a $\mathrm{pH}$ neutro, y capaz también de potenciar la degradación de otros CEC presentes. Por lo tanto, hemos confirmado que la interacción FQhierro, generalmente ignorada, siempre debe considerarse al realizar estudios de foto-Fenton relacionados con estos antibióticos y análogos. Además, las constantes cinéticas de fotólisis fueron siempre mayores a pH neutro para cada FQ estudiada ya que su forma zwitteriónica es la más fotolábil de todas. 
El otro aspecto importante de la tesis fue el uso de procesos Fenton basados en ZVI. Algunos CEC, como los compuestos nitroaromáticos, exhiben tasas de degradación lentas incluso cuando son degradadas por una AOP. El desarrollo de trenes de tratamiento ZVI para la degradación de contaminantes ha despertado un gran interés en los últimos años. Este enfoque consiste en un primer pretratamiento solo con ZVI (es decir, reducción, deshalogenación), seguido del proceso Fenton aprovechando los iones de hierro liberados en el primer paso. Con el fin de analizar las posibles ventajas e inconvenientes de esta estrategia en las aplicaciones de tratamiento de aguas residuales, se ha estudiado este enfoque empleando micropartículas de ZVI (mZVI) comerciales utilizando ácido p-nitrobenzoico (PNBA) como contaminante modelo. Se analizó el efecto de la cantidad inicial de mZVI, $\mathrm{H}_{2} \mathrm{O}_{2}, \mathrm{pH}$, conductividad, aniones y oxígeno disuelto. Utilizando agua natural en condiciones aeróbicas, pH inicial 3,0, y adicionando 1,4 g/L de mZVI, se consiguió en 2 h una reducción del $83 \%$ de PNBA $6 \mu \mathrm{M}$ en ácido p-aminobenzoico (PABA). Se investigó también la conveniencia de separar las mZVI después de la fase reductora (antes de la etapa Fenton) así como la reutilización de las mZVI. El paso de Fenton contra el PABA, más reactivo que PNBA, requirió $50 \mathrm{mg} / \mathrm{L}$ de $\mathrm{H}_{2} \mathrm{O}_{2}$ para lograr una eliminación de más del 96\% en 15 min a pH 7,5 (pH final del pretratamiento reductivo). Las mZVI reutilizadas fueron efectivas por lo menos por un ciclo completo (reducción/oxidación). Este enfoque puede ser interesante para tratar aguas residuales que contienen contaminantes inicialmente resistentes al radical hidroxilo $\left(\mathrm{HO}^{\bullet}\right)$, pero fácilmente reducibles, pudiendo disminuir su carga tóxica y aumentar su reactividad para un paso de oxidación posterior. 


\section{RESUM}

El món s'enfronta a l'escassetat d'aigua com a conseqüència global del Canvi Climàtic i a l'ús excessiu d'aigua potable, per la qual cosa es requereixen, urgentment, procediments de gestió d'aquest recurs molt més eficients (per ex., l'ús d'aigua recuperada). Els productes farmacèutics, plaguicides, retardants de flama i moltes altres substàncies que s'utilitzen diàriament en llars, indústries o granges, són presents en les aigües residuals urbanes en concentracions mínimes (ng $-\mu \mathrm{g} / \mathrm{L})$. Aquestes substàncies, denominades contaminants de preocupació emergent (CEC), generalment no són biodegradables, presentant una degradació baixa o incompleta enfront de l'actual tecnologia emprada en les plantes de tractament d'aigües residuals (WWTP) (típicament, fangs activats), i, per tant, sent després introduïts en el medi ambient durant la descàrrega dels efluents. Els problemes associats amb els CEC poden ser varis, com els efectes toxicològics (aguts i de bioacumulació) cap a la biota aquàtica, mal a l'ecosistema, proliferació de bacteris resistents als antibiòtics, entre altres. En consequiència, els denominats Processos Avançats d'Oxidació (AOP) han d'acoblar-se a les WWTP perquè l'efluent tinga la qualitat suficient requerida en vistes de les futures directives. Per a aquest treball, ens hem centrat, principalment, en processos Fenton, foto-Fenton(-solar) i Fenton basat en ferro zero-valent (ZVI).

Fenton i foto-Fenton van ser emprats per a degradar fluoroquinolones (FQ) (una classe d'antibiòtics sintètics considerats CEC) com a contaminants model en diferents condicions: $\mathrm{pH}$ $(3-8)$, concentració de contaminant $(3-300 \mu \mathrm{M})$, nombre de FQ presents $(1,3$ i 5$)$, i matriu d'aigua (aigua ultrapura, salada i de WWTP simulada). Els experiments es van realitzar a escala de laboratori i planta pilot, emprant llum solar (simulada i real) i irradiacions amb llum ultraviolada. Les velocitats de degradació de contaminants obtingudes amb processos tipusFenton es van comparar amb fotòlisi, fotocatàlisi heterogènia $\mathrm{i}_{2} \mathrm{O}_{2} / \mathrm{UV}$. En igualtat de condicions, només a través del procés foto-Fenton es va aconseguir una mineralització significativa de FQ. En aquells casos en els quals el carboni orgànic total no va mostrar una disminució considerable, la raó s'atribueix a l'alliberament de subproductes d'oxidació.

Tenint en compte que les FQ són fluorescents, decidim emprar matrius d'excitacióemissió de fluorescència (EEM) en combinació amb l'eina quimiométrica, anàlisi paral·lela de factors (PARAFAC) per a estudiar les seues degradacions. Si bé la metodologia EEMPARAFAC és utilitzada majoritàriament dins de la caracterització i monitoratge de matèria 
orgànica dissolta $(\mathrm{DOM})$ en aigües naturals i efluents (estudiat també en aquest treball per a estudiar els canvis del DOM en les diferents etapes d'una planta d'aigua potable), és pràcticament la primera vegada que és utilitzada per als fins que hem proposat en aquest treball. L'objectiu seria demostrar que EEM-PARAFAC és una metodologia complementària factible per a l'estudi de degradacions de CECs fluorescents, evitant l'ús de tècniques costoses i sofisticades (per exemple, espectrometria de masses), no sempre disponibles.

EEM-PARAFAC ha demostrat ser una tècnica econòmica, que no requereix de l'ús de reactius, i ràpida, per a seguir simultàniament l'eliminació de la degradació de fins a 5 FQ fluorescents presents en una mateixa mostra, en presència d'interferències sense calibrar, $\mathrm{i}$ obtindre informació sobre les possibles estructures moleculars dels intermediaris de reacció. Els resultats van indicar que la fotòlisi per si sola no és capaç de produir canvis importants en l'estructura de les FQ, mentre que amb (foto-)Fenton, sí que es va observar una notable disminució dels scores dels components PARAFAC associats amb el nucli de FQ. Els assajos de zona d'inhibició que empren $E$. coli van mostrar que l'activitat antibiòtica va disminuir en paral-lel amb la desintegració de tots els components PARAFAC relacionats amb FQ i subproductes similars a FQ.

El ferro interacciona amb les FQ formant complexos de coordinació. Per a l'enrofloxacina (ENR), una de les FQ més utilitzades i freqüents en aigües, es va observar que es forma un complex estable amb $\mathrm{Fe}^{3+}$ en un rang de $\mathrm{pH}$ des de 3.0 a 7.5, d'estequiometria ENR: $\mathrm{Fe}^{3+}=3: 1$. El temps de vida mitjana $\left(\mathrm{t}_{1 / 2}\right)$ de l'ENR baix condicions simulades pel sol va ser d'al voltant de $22 \mathrm{~min}$, mentre que la coordinació amb el ferro va millorar la seua fotoestabilitat, la qual cosa va portar a un $\mathrm{t}_{1 / 2}$ de $2,1 \mathrm{~h}$. A més, la generació de espècies d'oxigen reactiu i els intermediaris de reacció formats també són dependents del ferro. No obstant això, en presència de $\mathrm{H}_{2} \mathrm{O}_{2}$, ocorre el procés foto-Fenton, sent eficaç fins $\mathrm{i}$ tot a $\mathrm{pH}$ neutre, capaç també de potenciar la degradació d'uns altres CEC presents. Per tant, hem confirmat que la interacció FQ-ferro, generalment obviada, sempre ha de considerar-se en realitzar estudis de foto-Fenton relacionats amb aquests antibiòtics i similars. Les constants de velocitat van ser més altes a pH neutre per a cada FQ estudiada, ja que la seua forma zwitteriònica és més fotolàbil de totes.

L'altre aspecte important de la tesi va ser l'ús de processos Fenton basats en ZVI. Alguns CEC, com els compostos nitroaromàtics, exhibeixen taxes de degradació lentes fins i tot quan són degradats per un AOP. El desenvolupament de trens de tractament basats en ZVI per a la 
degradació de contaminants ha despertat un gran interés en els últims anys. Aquesta aproximaciót consisteix en un primer pretractament amb ZVI (és a dir, reducció, deshalogenación), seguit del procés Fenton aprofitant els ions de ferro alliberats en el primer pas. Amb la finalitat d'analitzar els possibles avantatges i inconvenients d'aquesta estratègia en les aplicacions de tractament d'aigües residuals, s'han emprat micropartícules de ZVI (mZVI) comercials. Utilitzant àcid p-nitrobenzoic (PNBA) com a contaminant model, es va analitzar l'efecte de la quantitat inicial de mZVI, $\mathrm{H}_{2} \mathrm{O}_{2}, \mathrm{pH}$, conductivitat, anions i oxigen dissolt. Utilitzant aigua natural en condicions aeròbiques, $\mathrm{pH}$ inicial 3,0, i addicionant 1,4 $\mathrm{g} / \mathrm{L}$ de mZVI, es va aconseguir en $2 \mathrm{~h}$ una reducció del 83\% de PNBA $6 \mu \mathrm{M}$ a àcid p-aminobenzoic (PABA). Es va investigar també la conveniència d'eliminar les mZVI després de la fase reductora (abans de l'etapa Fenton) així com la reutilització de les mZVI. El pas de Fenton front el PABA, més reactiu que PNBA, va requerir $50 \mathrm{mg} / \mathrm{L}$ de $\mathrm{H}_{2} \mathrm{O}_{2}$ per a aconseguir una eliminació de més del 96\% en 15 min a $\mathrm{pH}$ 7,5 (pH final del pretractament reductiu). Les mZVI reutilitzades van ser efectives almenys amb un cicle complet (reducció/oxidació). Aquest enfocament pot ser interessant per a tractar aigües residuals que contenen contaminants inicialment resistents al $\mathrm{HO}^{\bullet}$, però que es redueixen fàcilment, podent disminuir la seua càrrega tòxica i augmentar la seua reactivitat per a un pas d'oxidació posterior. 


\section{CONTENTS}

1. INTRODUCTION

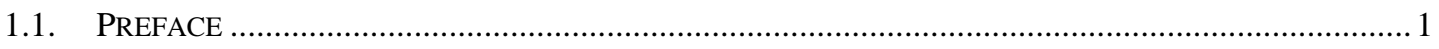

1.2. IS THE USE OF RECLAIMED WATER STILL OPTIONAL? ...................................................................

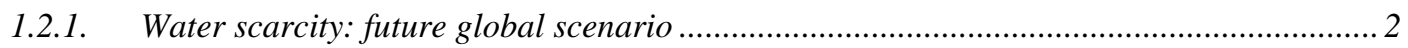

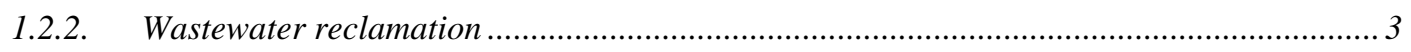

1.3. COMPOUNDS OF CONCERN TOWARDS WATER TREATMENT ……….......................................

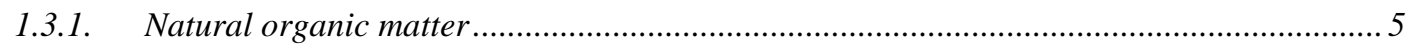

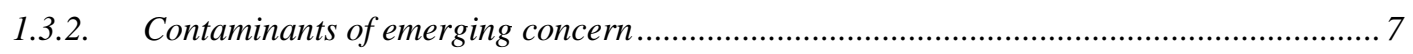

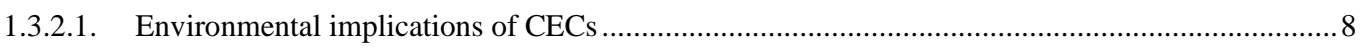

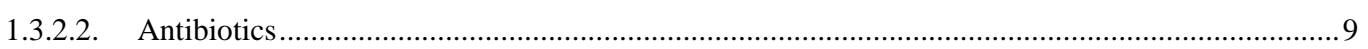

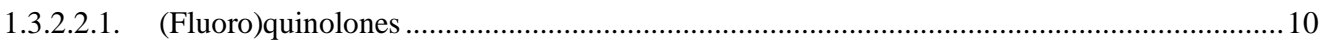

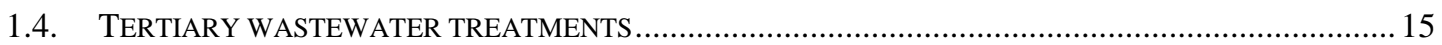

1.4.1. Advanced Oxidation Processes...................................................................................... 16

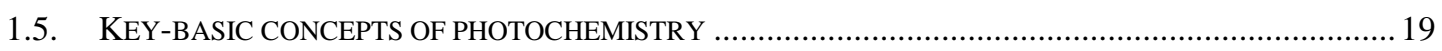

1.5.1. Electronic spectroscopy of transition-metal complexes.............................................. 21

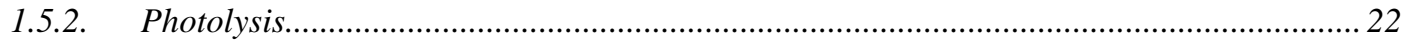

1.6. PROCESSES INVOLVING IRON FOR CONTAMINANTS ABATEMENT …………………….................. 23

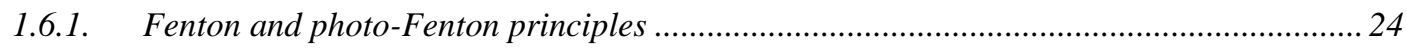

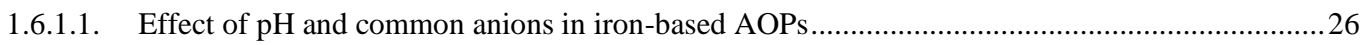

1.6.1.2. Enhancing the (photo)-Fenton process at circumneutral $\mathrm{pH}$...................................................2 27

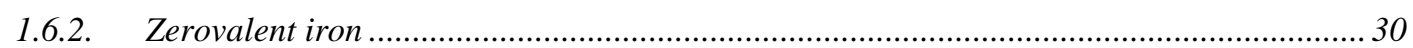

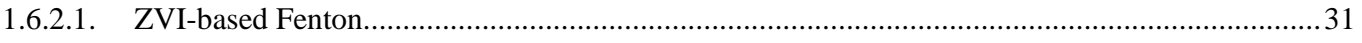

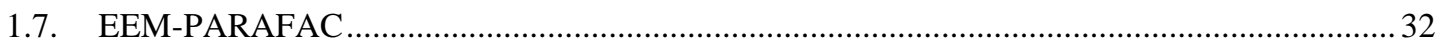

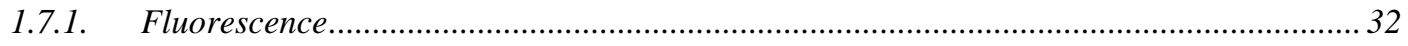

1.7.1.1. Fluorescence excitation-emission matrix (EEM) ...................................................................... 34

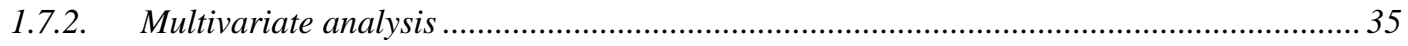

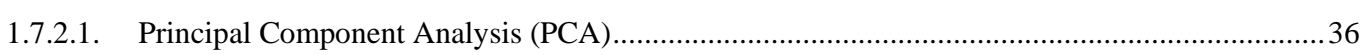

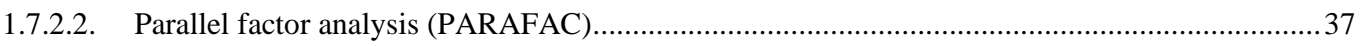

1.7.2.2.1. Examples of the EEM-PARAFAC use within the water treatment studies ..........................40

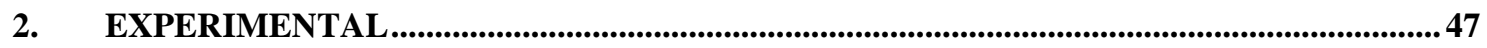

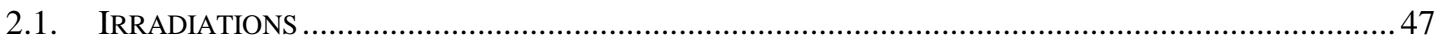

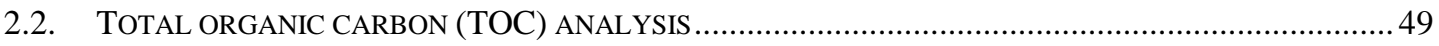

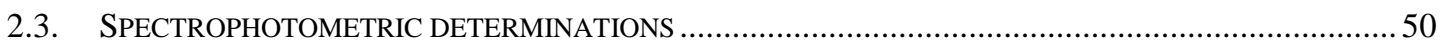

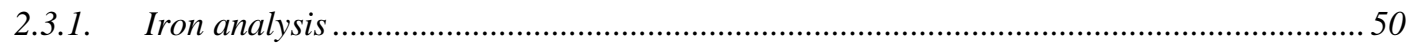

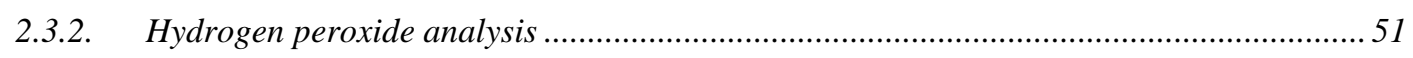

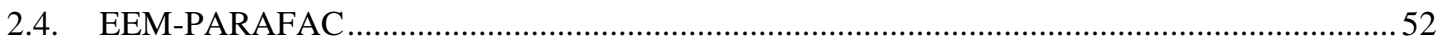

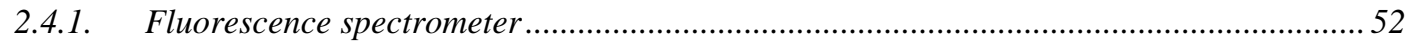




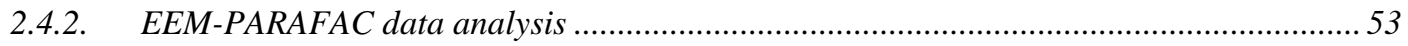

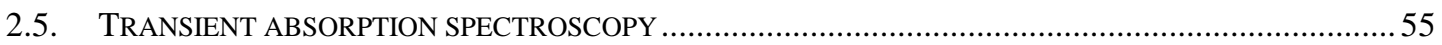

2.6. HIGH-PERFORMANCE LIQUID CHROMATOGRAPHY (HPLC) ....................................................5

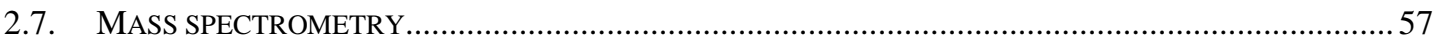

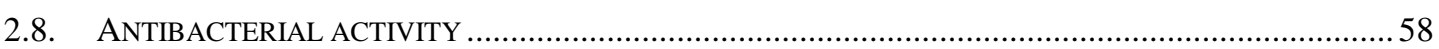

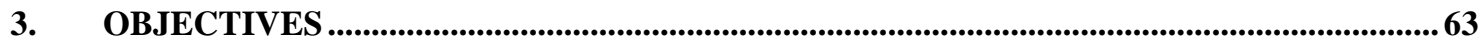

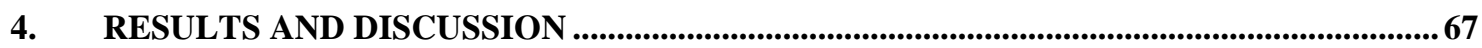

4.1. SIGNIFICANT ROLE OF IRON ON THE FATE AND PHOTODEGRADATION OF ENROFLOXACIN ............67

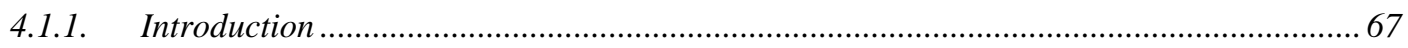

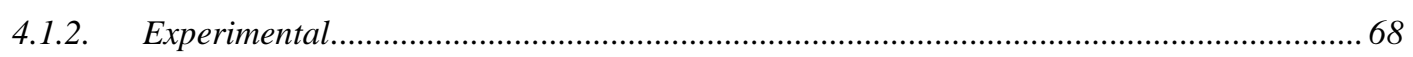

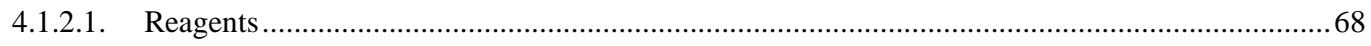

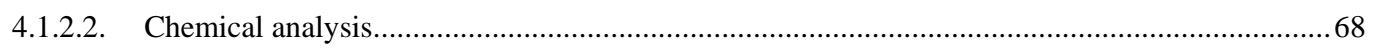

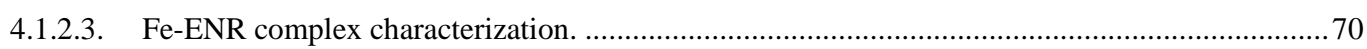

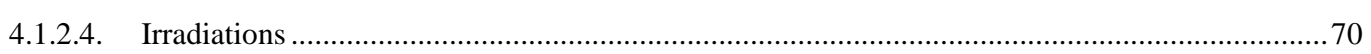

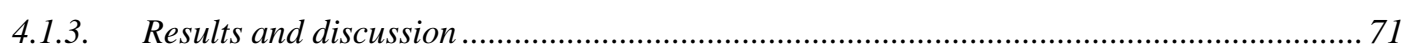

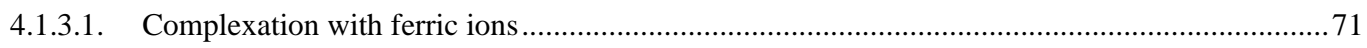

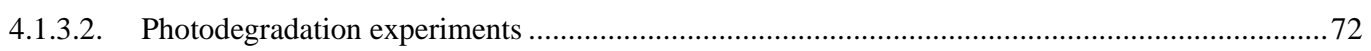

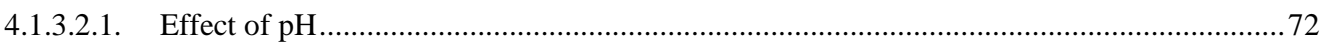

4.1.3.2.2. ROS generation and effect of dissolved oxygen ................................................................. 75

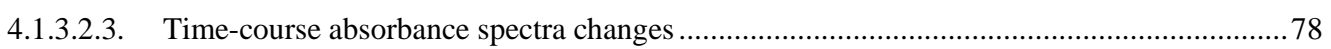

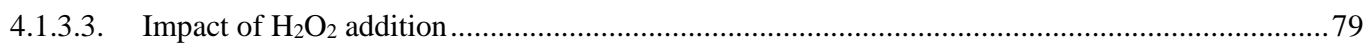

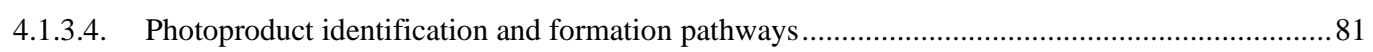

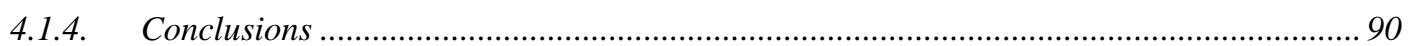

4.2. Magnetic Photocatalyst For Wastewater Tertiary Treatment at Pilot Plant

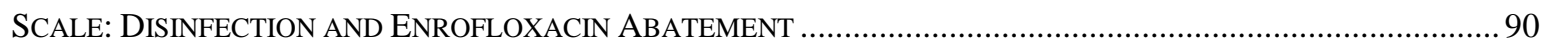

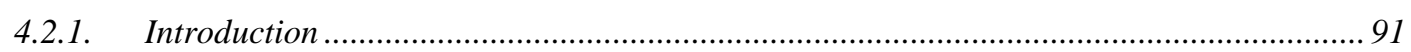

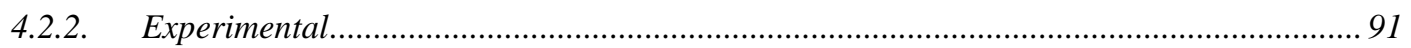

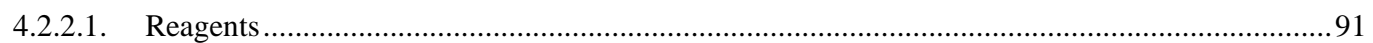

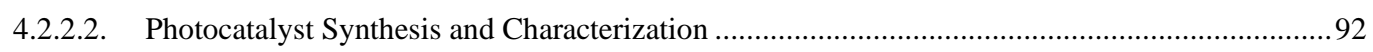

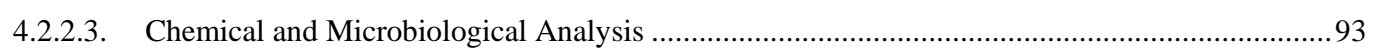

4.2.2.4. Experimental Procedures and Set-Up at Pilot Plant Scale ..........................................................94

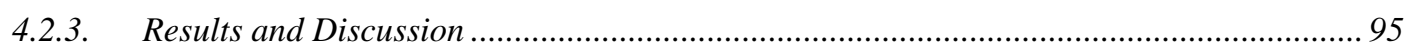

4.2.3.1. Study of the Operational Parameters ........................................................................................ 95

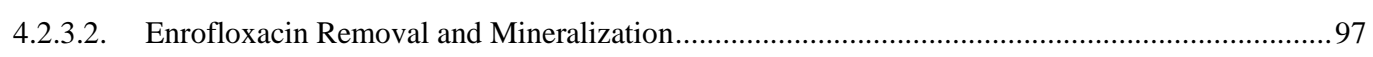

4.2.3.3. Magnox/UVC Influence on MWWTP Water........................................................................... 98

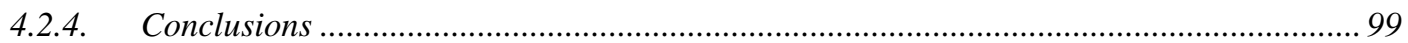

4.3. MONITORING PHOTOLYSIS AND (SOLAR PHOTO)-FENTON OF ENROFLOXACIN BY A METHODOLOGY INVOLVING EEM-PARAFAC AND BIOASSAYS: ROLE OF PH AND WATER MATRIX..................................... 100

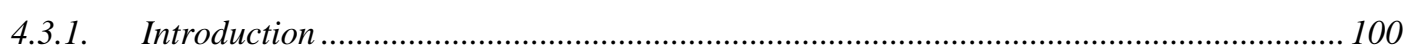

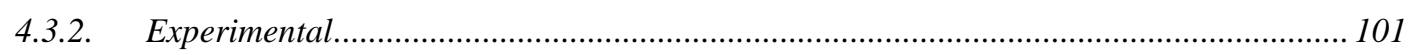

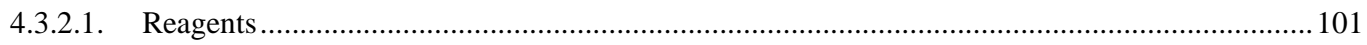




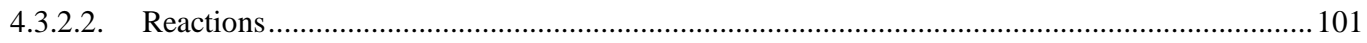

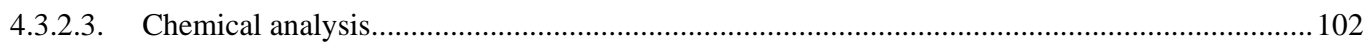

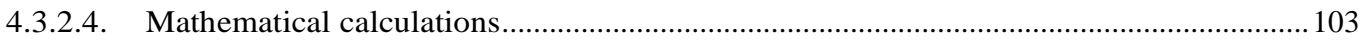

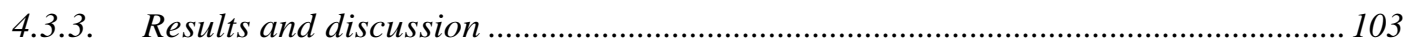

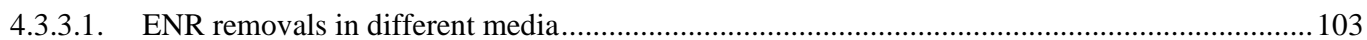

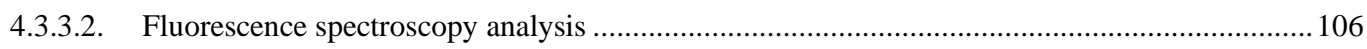

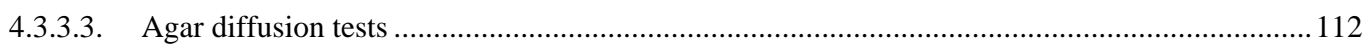

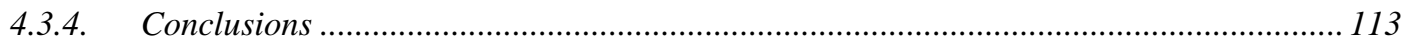

4.4. FLuORESCENCE SPECTROSCOPY AND CHEMOMETRICS: A SiMPLE AND EASY WAY FOR THE

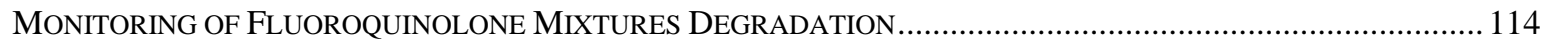

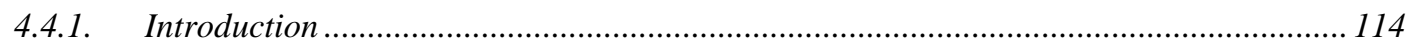

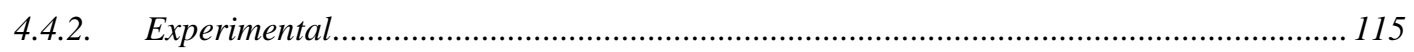

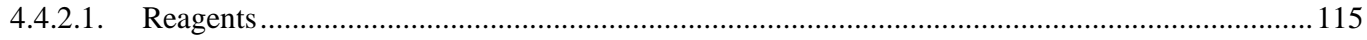

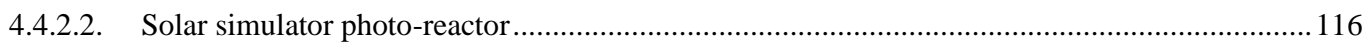

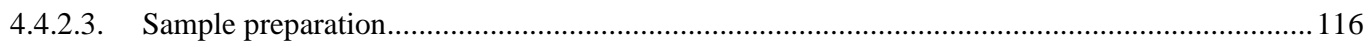

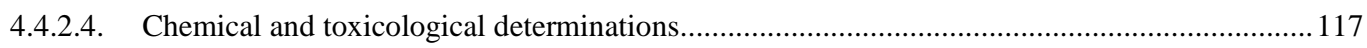

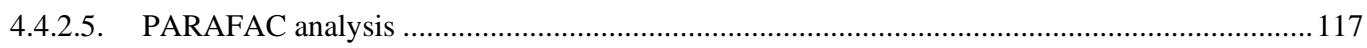

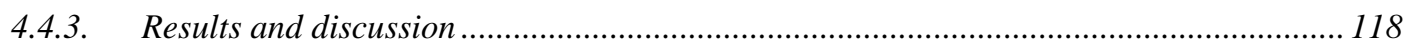

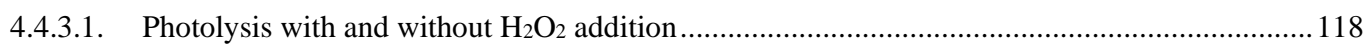

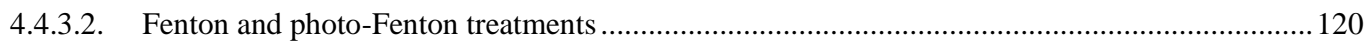

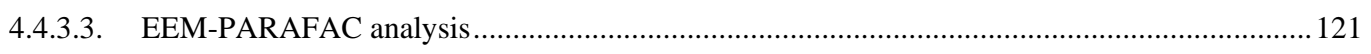

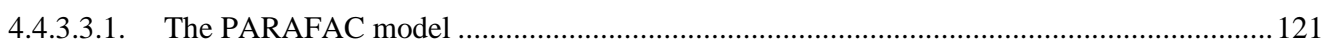

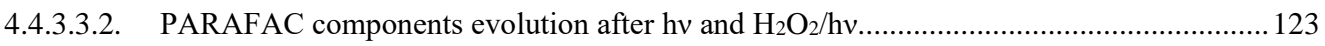

4.4.3.3.3. PARAFAC components evolution after Fenton and photo-Fenton treatments .................... 124

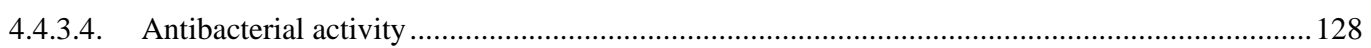

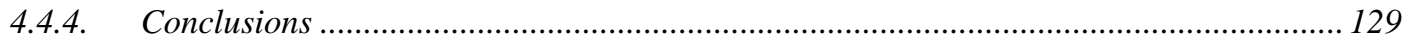

4.5. DEGRADATION OF A MIXTURE OF (FLUORO)QUINOLONES ANTIBIOTICS WITH SOLAR-PHOTOFENTON WITH A CPC PILOT PLANT: EEM-PARAFAC USE............................................................... 129

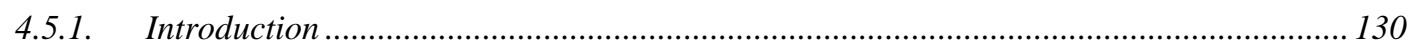

4.5.2. Experimental...................................................................................................... 130

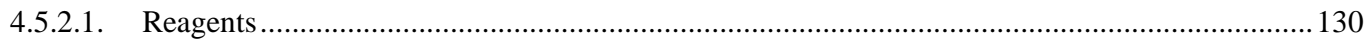

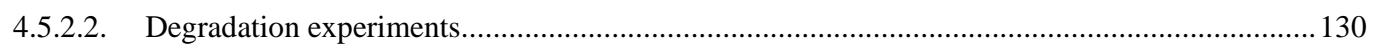

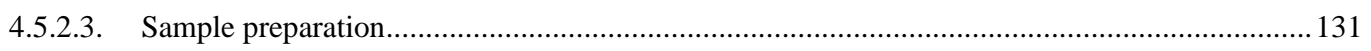

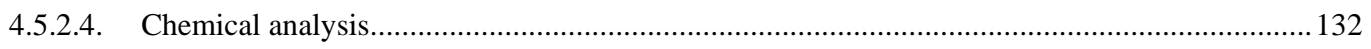

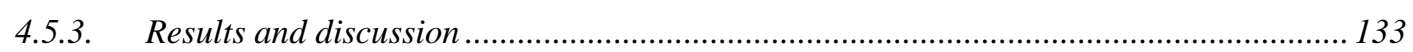

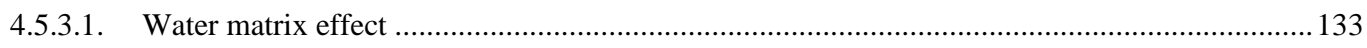

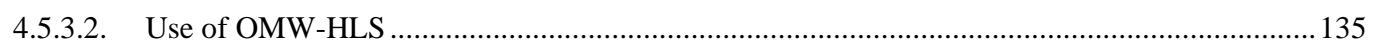

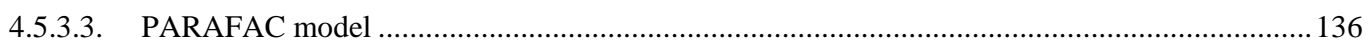

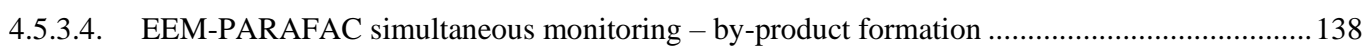

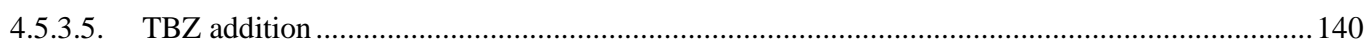

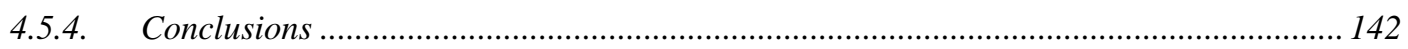

4.6. DISSOLVED ORGANIC MATTER MONITORING AMONG THE TURIN DRINKING WATER PLANTS 


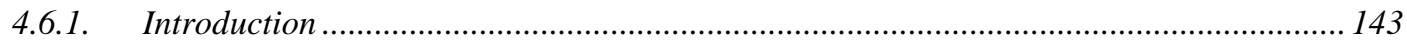

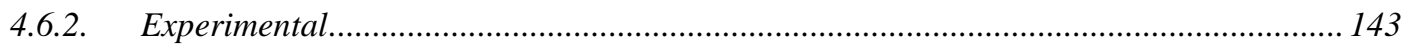

4.6.2.1. Description of the working environment: the DWTP of Turin................................................. 143

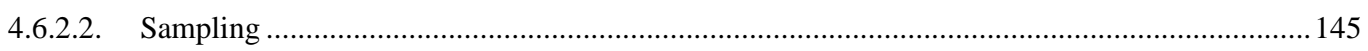

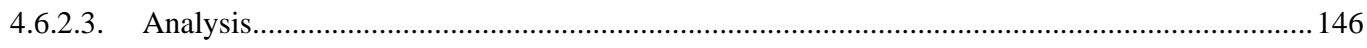

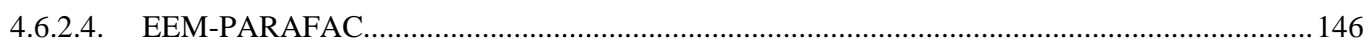

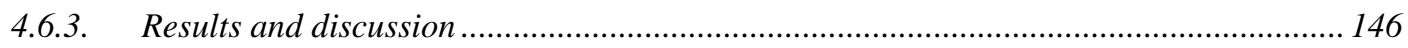

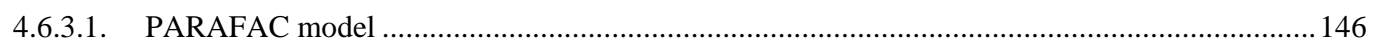

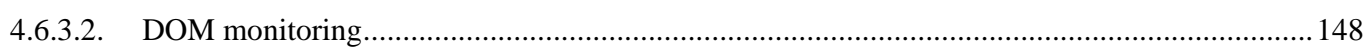

4.6.3.2.1. Characterization of the inlet effluents of the DWTP (sites A to E) .................................... 149

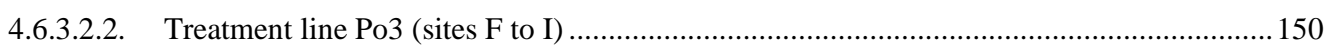

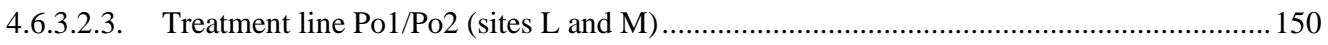

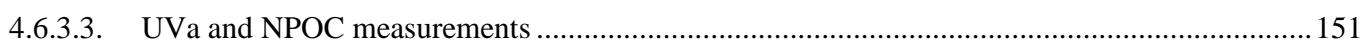

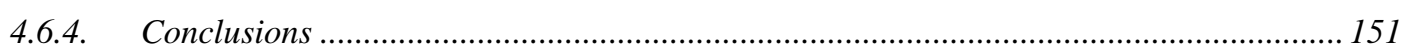

4.7. A RATIONAL ANALYSIS ON KEY PARAMETERS RULING ZEROVALENT IRON-BASED TREATMENT TRAIN: TOWARDS THE SEPARATION OF REDUCTIVE FROM OXIDATIVE PHASES ............................................. 152

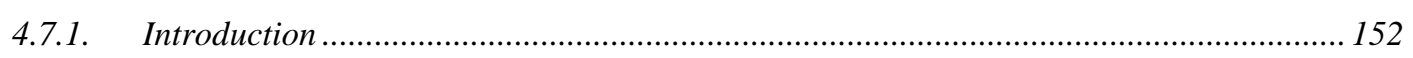

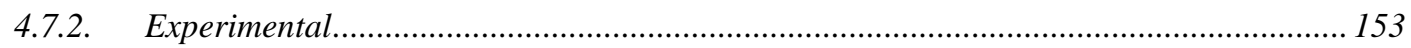

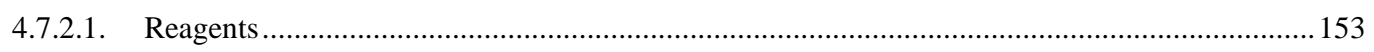

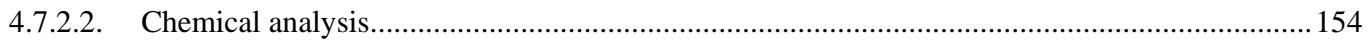

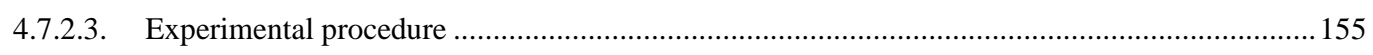

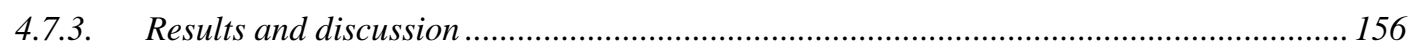

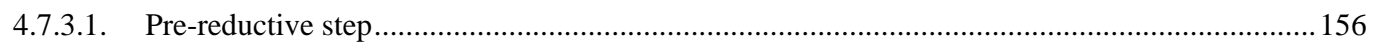

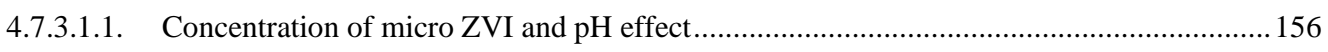

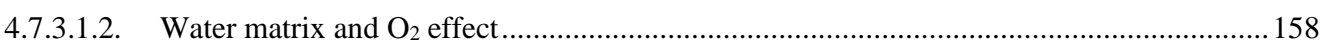

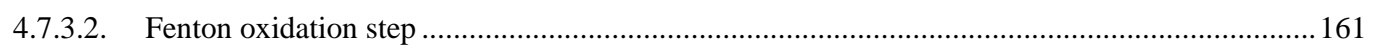

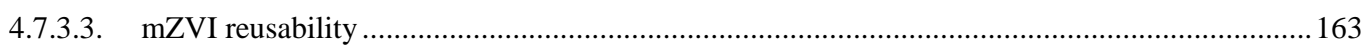

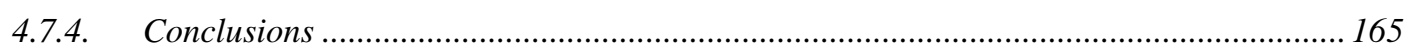

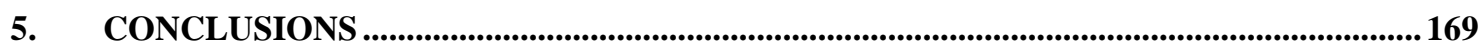

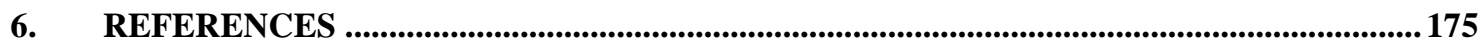

\section{LIST OF FIGURES}

FIGURE 1.1. RENEWABLE FRESHWATER RESOURCES PER YEAR FOR BRAZIL, EU AND MIDDLE EAST. DATA OBTAINED FROM OUR WORLD IN DATA ACCESSED ON NOVEMBER 2020 [4] ....................................... 3

FIGURE 1.2. CLASSIFICATION OF THE DIFFERENT TYPES OF DOM BASED ON THE REVIEW PUBLISHED BY LEENHEER

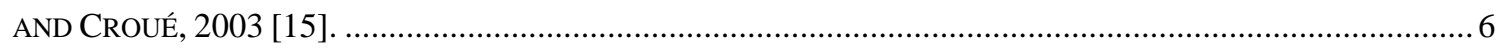

FIGURE 1.3. SCHEMATIC MAIN IMPROVEMENTS AMONG FLUOROQUINOLONES DEVELOPMENT............................ 10 FIGURE 1.4. FQ INTERACTION MODEL DURING INHIBITION OF DNA GYRASE ENZYME. ADAPTED FROM FIGURES OF ROSEN ET AL., 1989 [37]. 11 


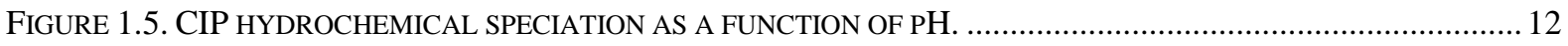

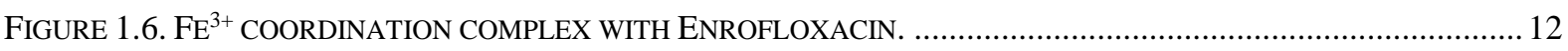

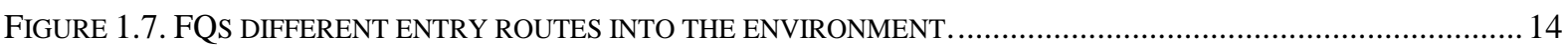

FIGURE 1.8. NUMBER OF PUBLICATIONS FOR AOP RELATED WORKS (SOURCE: HTTP://WWW.SCOPUS.COM, FEBRUARY 2021, SEARCHED TERM: “ADVANCED OXIDATION PROCESS”). 18

FIGURE 1.9. JABLONSKI DIAGRAM FOR A GENERIC MOLECULE WITH SINGLET GROUND STATE ( $\left.{ }^{1} \mathrm{X}\right)$. ARROW'S COLORS INDICATE THE DIFFERENT PHOTOCHEMICAL PROCESSES: EXCITATION $(\rightarrow)$; INTERNAL CONVERSION $(\rightarrow)$; FLUORESCENCE $(\rightarrow)$; INTERSYSTEM CROSSING $(\rightarrow)$; PHOSPHORESCENCE $(\rightarrow)$; VIBRATIONAL $\operatorname{RELAXATION~}(\rightarrow)$; A TYPE OF QUENCHING $(\rightarrow)$.

FIGURE 1.10. ELECTRONIC TRANSITIONS FOR OCTAHEDRAL COORDINATION COMPLEXES: LIGAND TO METAL CHARGE TRANSFER $($ LMCT) $(\rightarrow)$, LIGAND TO LIGAND CHARGE TRANSFER $(\rightarrow)$, METAL TO LIGAND CHARGE TRANSFER $(\rightarrow)$ AND D-D $(\rightarrow)$.

FIGURE 1.11. FE $^{3+}$ HYDROLYSIS: A) MOLAR ABSORPTIVITY COEFFICIENT FOR THE DIFFERENT FE ${ }^{3+}$ AQUOCOMPLEXES; B) SPECIATION PLOT. FIGURES WERE TAKEN FROM STEFÁNSSON, 2007 [76].

FIGURE 1.12. A) STOKES SHIFT. RED AND BLUE TRIANGLES SYMBOLIZE THE FLUOROPHORE AND SOLVENT DIPOLE MOMENTS, RESPECTIVELY; B) FRANK-CONDON PRINCIPLE FOR AN EXCITATION (BLUE) AND FLUORESCENCE (GREEN) TRANSITIONS BETWEEN GROUND AND EXCITED STATES ( $\mathrm{S}_{0}$ AND $\mathrm{S}_{1}$, RESPECTIVELY) [112]........... 33

FIGURE 1.13. ENR 1.4 MM FLUORESCENCE AT PH 4.0 IN ULTRA-PURE WATER: A) NORMALIZED EXCITATION $\left(\Lambda_{\mathrm{EM}}=445 \mathrm{NM}\right.$, FULL LINE) AND EMISSION ( $\Lambda_{\mathrm{EX}}=270 \mathrm{NM}$, DOTTED LINE) SPECTRUMS; B) EEM; C) BIDIMENSIONAL EEM.

FIGURE 1.14. 2-WAY PCA SCHEME FOR A GENERIC SYSTEM INITIALLY ANALYSED BY VARIABLES $X_{1}$ AND $X_{2}$. PRINCIPAL COMPONENTS, $C_{l}$ AND $C_{2}$, ARE SHOWN IN RED LINES.

FIGURE 1.15. PARAFAC COMPONENTS MODEL WITHOUT CHEMICAL CONSISTENCY. INSERTED NUMBERS INDICATE THE FOLLOWING INCONSISTENCIES: (1) EXCITATION AND EMISSION SPECTRUMS SIGNIFICANT OVERLAPPING; (2) MULTIPLE DISTINCT EMISSION PEAKS, (3) EXCITATION EXTINGUISH; (4) ABRUPT SPECTRAL CHANGES OVER SHORT WAVELENGTH DISTANCES. THE LIGHT AND DARK CURVES REPRESENT EXCITATION AND EMISSION SPECTRA, RESPECTIVELY [117].

FIGURE 1.16. PARAFAC USED FOR FLUORESCENT SIGNAL DECONVOLUTION FOR AN EEM DATASET. A MODEL OF 7 COMPONENTS AND THEIR SCORES FROM EACH OF THE DATASET'S SAMPLES (TIME INTERVALS) IS THE FINAL RESULT.

FIGURE 1.17. EXAMPLE OF EEMLAB GUI EMPLOYING DREEM TOOLBOX [122] ON MATLAB TO RUN PARAFAC IN AN EASIER WAY WITHOUT THE NEED OF HAVING PROGRAMMING KNOWLEDGE.

FIGURE 1.18. TYPICAL FLUORESCENT DOM EEM MAXIMUMS (ALSO CONSIDERING SECOND EXCITATION MAXIMUMS) REGIONS [125].

FIGURE 2.1. NORMALIZED EMISSION SPECTRUMS (MEASURED WITH A CHARGE-COUPLED DEVICE SPECTROPHOTOMETER, OCEAN OPTICS USD 2000CUV-VIS) FOR SUNLIGHT AND DIFFERENT LAMPS: UVB, UVA AND XE

FIGURE 2.2. A) SCHEME OF AN ORIEL INSTRUMENT SOLAR SIMULATOR COMPONENTS; B) FRONTAL PICTURE...... 48 FIGURE 2.3. CPC REACTOR: A) RADIATION COLLECTION SCHEME, TAKEN FROM S. MALATO ET AL., 2009 [57]; B) PICTURE OF THE EMPLOYED 5 L PILOT PLANT SOLARDETOX ACADUS-2001. 
FIGURE 2.4. CALIBRATION CURVES FOR IRON SPECTROPHOTOMETRIC DETERMINATION EMPLOYING METHOD: A) 1, 10-PHENANTHROLINE, B) FERROZINE. . .51

FIGURE 2.5. CALIBRATION CURVES FOR HYDROGEN PEROXIDE SPECTROPHOTOMETRIC DETERMINATION EMPLOYING METHOD: A) $\mathrm{NH}_{4} \mathrm{VO}_{3}$, B) $\mathrm{TIOSO}_{4}$. 52

FIGURE 2.6. SPECTROFLUOROMETER OF TWO MONOCHROMATORS: A) SCHEME; B) PICTURE.................................53

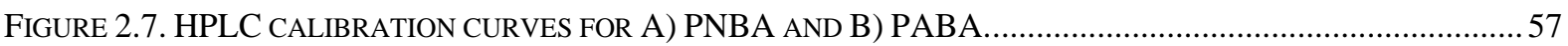

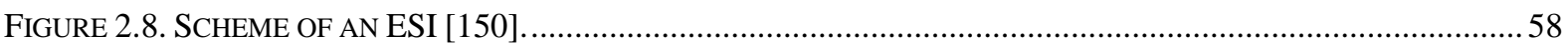

FIGURE 2.9. ANTIBACTERIAL ACTIVITY EXAMPLE FOR ENR 25 MG/L. IN ALL CASES, IN THE WELL X CONTROL

SAMPLE (WATER ALONE) WAS ADDED, WHEREAS IN A, B, C AND D WELLS THE DEGRADATION TIMES 0, 15,

30 AND 60 MINUTES FOR: A) PHOTOLYSIS; B) PHOTO-FENTON.

FigURE 4.1. (A) ABSORPTION SPECTRA FOR ENR, FE(III) AND FE ${ }^{\text {III }}$-ENR 3 AT PH 3.0; (B) METHOD OF

CONTINUOUS VARIATION FOR A FIXED AMOUNT OF FE(III) $100 \mu \mathrm{M}$ AND VARIATING ENR CONCENTRATION FROM 100 TO $600 \mu \mathrm{M}$. INSERT REPRESENT THE UV-VIS SPECTRA OF DIFFERENT ENR/FE(III) RATIO SOLUTIONS AT PH 3.0. (C) FE(III) CONCENTRATION FROM $100 \mu \mathrm{M} \mathrm{FE}^{\text {III-ENR }}{ }_{3}$ COMPLEX AT DIFFERENT PH VALUES MEASURED 24 H AFTER PREPARATION. PTFE FILTERS $0.45 \mu \mathrm{M}$ WERE USED TO FILTER SOLUTIONS. VALUES REPRESENT THE AVERAGE OF TWO MEASUREMENTS, AND THE ERROR BAR GIVES THE ASSOCIATED UNCERTAINTY [118].

FigURE 4.2. PhOTOLYTIC RATE CONSTANTS FOR ENR $300 \mu \mathrm{M}$ AND FE ${ }^{\mathrm{III}}$-ENR $3100 \mu \mathrm{M}$ AT ALL TESTED CONDITIONS (ERROR BARS WERE CALCULATED FROM THE DEVIATION FROM LINEAR FIT AND EXPERIMENTAL DATA) [118]

FIGURE 4.3. ENR PKA DETERMINATION ([ENR] $=15 \mu \mathrm{M})$. A) DIFFERENT SPECTRA AS FUNCTION OF PH (PH 2.5 TO 10.5), B) MOLAR ABSORPTION COEFFiCIENT ( $\varepsilon$ ) AT 275 NM AS FUNCTION OF PH [118]. .74

FIGURE 4.4. EFFECT OF ROS SCAVENGER ADDITION (IPA 5 MM AND FFA $300 \mu \mathrm{M}$ ) AT AERATED CONDITIONS.

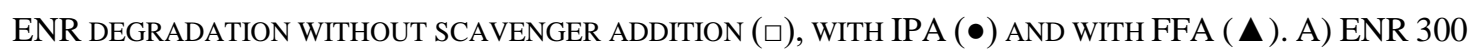
$\mu \mathrm{M}$ PH 3.0; B) FE ${ }^{\mathrm{III}}$-ENR $3100 \mu \mathrm{M}$ PH 3.0; C) ENR $300 \mu \mathrm{M}$ PH 7.0; D) FE ${ }^{\text {III-ENR }} 3100 \mu \mathrm{M}$ PH 7.0 [118].... 74

FIGURE 4.5. FFA $300 \mu \mathrm{M}$ REMOVAL BY ${ }^{1} \mathrm{O}_{2}$ GENERATION AT DIFFERENT TESTED CONDITIONS: ENR $300 \mu \mathrm{M}$ PH 3.0 (口), FEIII-ENR3 $100 \mu \mathrm{M}$ PH $3.0(\bullet)$, ENR $300 \mu \mathrm{M}$ PH $7.0(\triangle)$, FEIII-ENR3 $100 \mu \mathrm{M}$ PH 7.0 ( $(\Delta)$ ). CONTROL: FFA PHOTODEGRADATION ALONE AT BOTH STUDIED PH WAS NEGLIGIBLE (1-3\% IN 120 MIN) [118]..........76 FIGURE 4.6 ENR $280 \mu \mathrm{M}$ LASER FLASH PHOTOLYSIS MEASUREMENTS: A) AND B) ${ }^{3}$ ENR* RELAXATION KINETICS AT PH 3.0 AND 7.0, RESPECTIVELY, AT DE-AERATED, AERATED AND OXYGEN SATURATED CONDITIONS, WITH ${ }^{3} \mathrm{O}_{2}$ QUENCHING KINETIC RATE CONSTANT DETERMINATION (INSERTED GRAPH); C) ${ }^{3}$ ENR* ABSORBANCE SPECTRA AT BOTH STUDIED PH (MEASURED AT $0.09 \mu$ S) [118]

FIGURE 4.7. FE(II) FORMATION FROM FE ${ }^{\mathrm{III}}$-ENR $\left.\mathrm{E}_{3}\left([\mathrm{FE}(\mathrm{IIII})]_{0}=100 \mu \mathrm{M} \text {, [ENR }\right]_{0}=300 \mu \mathrm{M}\right)$ AT PH 3.0 UNDER IRRADIATIONS IN DE-AERATED $(\bullet)$, AERATED $(\bullet)$ AND OXYGEN SATURATED CONDITIONS ( $(\boldsymbol{\Delta})$ [118].......... 77

FIGURE 4.8. TIME-COURSE ABSORBANCE SPECTRA CHANGES DURING IRRADIATION EXPERIMENTS AT PH 3.0 AND PH 7.0. FULL SPECTRA WERE RECORDED BY 20 TIMES DILUTION OF THE ORIGINAL SAMPLE (IN THE INSERT). (A) ENR $300 \mu \mathrm{M}$ PH 3.0; (B) FE ${ }^{\mathrm{III}}$-ENR $3100 \mu \mathrm{M}$ PH 3.0; (C) ENR $300 \mu \mathrm{M}$ PH 7.0; (D) FE ${ }^{\mathrm{III}}$-ENR $3100 \mu \mathrm{M}$ PH 7.0 [118]...........

FIGURE 4.9. DEGRADATION PERCENTAGES AFTER 60 MIN AT BOTH STUDIED PH IN AERATED CONDITIONS, UNDER SUNLIGHT IRRADIATION (HN), WITH $\mathrm{H}_{2} \mathrm{O}_{2} 200 \mu \mathrm{M}$ WITHOUT IRRADIATION (DARK CONTROL), AND THE 
COMBINATION OF BOTH, HN+H $\mathrm{O}_{2} 200 \mu \mathrm{M}$, FOR $300 \mu \mathrm{M}$ OF ENR AND $100 \mu \mathrm{M}$ OF FE III-ENR $_{3}$. ERROR BARS WERE CALCULATED AS THE ASSOCIATED STANDARD DEVIATION BETWEEN RESPECTIVE DUPLICATES [118].

FIGURE 4.10. SUMMARY OF THE STUDIED REACTIONS AND PHOTOPRODUCT FORMATION MECHANISM PROPOSAL. UNDERLINED PHOTOPRODUCTS WERE FOUND FOR THE FIRST TIME IN THIS WORK. REACTIONS INCLUDE DEFLUORINATION (-F), DECARBOXYLATION (-COOH), HYDROXYLATION (+OH), PIPERAZINE CLEAVAGE AND OXIDATION (-PIP AND PIP-OX, RESPECTIVELY), AND ETHYL MOIETY CLEAVAGE AND OXIDATION (-ET AND ET-OX, RESPECTIVELY) [118].....

FIGURE 4.11. ALL DETECTED PHOTOPRODUCTS FOR ENR $300 \mu$ M (BLUE) AND FE ${ }^{\text {III-ENR }} 100 \mu$ M (ORANGE) AFTER 120 MIN OF: A) HN PH 3.0; B) $\mathrm{H}_{2} \mathrm{O}_{2}+\mathrm{HN}$ PH 3.0; C) HN + IPA PH 3.0; D) $\mathrm{HN}+\mathrm{H}_{2} \mathrm{O}_{2}$ + IPA PH 3.0; E) $\mathrm{HN}$ PH 7.0; F) $\mathrm{H}_{2} \mathrm{O}_{2}+\mathrm{HN}$ PH 7.0 [118]

FIGURE 4.12. OBTAINED PHOTOPRODUCTS FORMATION AFTER 120 MIN FOR ENR $300 \mu \mathrm{M}$ AND FE ${ }^{\mathrm{III}}$-ENR $3100 \mu \mathrm{M}$, PH 3.0 AND 7.0. ABOVE WITH ONLY LIGHT IRRADIATION (HN), AND BELOW WITH HN $+\mathrm{H}_{2} \mathrm{O}_{2} 200 \mu \mathrm{M}$ [118].

Figure 4.13. PHOTOPRODUCT FORMATION KINETICS WHEN $\mathrm{H}_{2} \mathrm{O}_{2} 200 \mu \mathrm{M}$ WAS ADDED AT PH 3.0 TO: A) ENR 300 $\mu \mathrm{M}, \mathrm{B}) \mathrm{FE}^{\mathrm{III}}-\mathrm{ENR}_{3} 100 \mu \mathrm{M}[118]$.

FigURE 4.14. SEM IMAGES FROM MAGNOX PHOTOCATALYST: (A) GENERAL VIEW OF THE PARTICLES; (B) SECTIONED AND POLISHED PARTICLE SHOWING THE SILICA (DARK LAYER SURROUNDING THE CENTRAL PORE), MAGNETITE (BRIGHTEST POINTS INSIDE SILICA LAYER), AND TITANIUM OXIDE (THE GREY LAYER

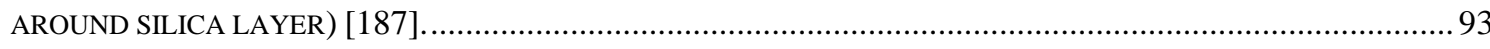

FIGURE 4.15. EMPLOYED PILOT PLANT: (A) SCHEME AND (B) PICTURE [187]....

Figure 4.16. DYE DECOLORIZATION (RHODAMINE-B (RB), 5 MG/L) BY MAGNOX/UltRAVIOLET LiGHT (UVC) WITHIN DIFFERENT TESTED OPERATIONAL CONDITIONS: DARK CONTROLS (ADSORPTION) WITH FIXED AIR FLOW OF 30 L/MIN, FOR 0.5 (O) AND 5 G/L (•) OF PHOTOCATALYST; AIR FLOW VARIATION WITH FIXED 0.5 G/L OF PHOTOCATALYST, 1.5 (汤) AND 30 L/MIN ( $\star$ ); AIR FLOW VARIATION WITH FIXED 5 G/L OF PHOTOCATALYST, 1.5 () AND 30 L/Min (ם); UVC ALONE (X) WITH 30 L/MIN AIR FLOW [187].

FIGURE 4.17. DYE DECOLORIZATION (RB 5 MG/L) PROFILES WITH THE DIFFERENT STUDIED ADVANCED OXIDATION PROCESSES (AOPS) WITH AIR FLOW OF 30 L/MIN AT (A) NATURAL PH AND (B) PH 2.8. STUDIED

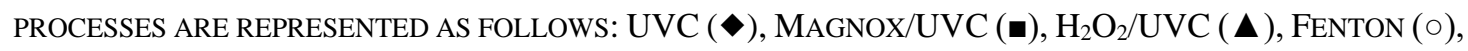
AND PHOTO-FENTON $(\bullet)[187]$

FIGURE 4.18. ENROFLOXACIN (ENR) 25 MG/L REMOVALS AT PH 2.8 WITH AIR FLOW OF 30 L/MIN. (A): UVC ( $)$ ),

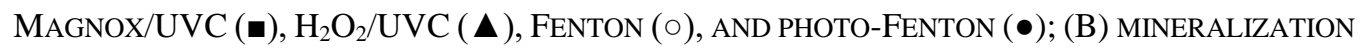
PERCENTAGES [187].

FIGURE 4.19. ENR DEGRADATION PROFILES IN MILLI-Q WATER: PHOTOLYSIS AT PH = 5 (ם); PHOTOLYSIS AT PH = $2.8(\square)$; FENTON AT PH $=5(\diamond)$; FENTON AT PH $=2.8(\diamond)$, PHOTO-FENTON AT PH $=5(\bullet)$ AND PHOTOFENTON AT PH $=2.8(\circ)[137]$. 105

FIGURE 4.20. ENR REMOVAL IN DIFFERENT AQUEOUS MEDIA FOR A) FENTON, B) SOLAR PHOTO-FENTON. SW AT $\mathrm{PH}=5(\diamond) ; \mathrm{SW}$ AT PH $=2.8(\diamond) ; \mathrm{TW}$ AT PH $=5(\triangle)$; TW AT PH $=2.8(\boldsymbol{\Delta}) ; \mathrm{MQ}$ AT PH $=5(\bullet)$ AND MQ AT

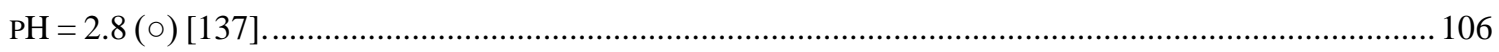


FIGURE 4.21. $\mathrm{H}_{2} \mathrm{O}_{2}$ CONSUMPTION FOR THE SOLAR PHOTO-FENTON PROCESS IN THE DIFFERENT STUDIED WATER MATRICES. SW AT PH $=5(\diamond)$; SW AT PH $=2.8(\diamond)$; TW AT PH $=5(\boldsymbol{\Delta})$; TW AT PH = $2.8(\triangle)$; MQ AT PH = 5 (О) AND MQ AT PH = $2.8(\circ)[137]$. 106

FIGURE 4.22. NORMALIZED FLUORESCENCE EXCITATION-EMISSION MATRICES OBTAINED AT DIFFERENT STAGES OF ENR DEGRADATION IN MQ AT INITIAL PH=2.8 (0, 5, 15, 30, 60 AND 120MIN) BY: A) FENTON, B) SOLAR PHOTO-FENTON AND C) DIRECT PHOTOLYSIS [137].

FIGURE 4.23. OBTAINED CORE CONSISTENCY DIAGNOSTIC VALUES (EXPRESSED AS PERCENTAGE) FOR THE DIFFERENT TESTED MODELS [137].

FIGURE 4.24. FINGERPRINTS OF THE 5 COMPONENTS OBTAINED AFTER THE MATHEMATICAL TREATMENT BY PARAFAC OF A SET OF 110 EEMS OBTAINED ALONG PHOTOLYSIS, FENTON AND SOLAR PHOTO-FENTON IN ALL THREE WATER MATRICES AND AT PH 2.8 AND 5.0 [137].....

FIGURE 4.25. PLOT OF THE FLOUROQUINOLONIC COMPONENTS OBTAINED IN THE EEM-PARAFAC MODEL (C1 AND C2) VS. TIME IN MQ WATER. PHOtOLYSIS AT PH = 5 (ם); PHOTOLYSIS AT PH = 2.8 ( $\square$ ); FENTON AT PH $=5(\diamond)$; FENTON AT PH $=2.8(\diamond)$, PHOTO-FENTON AT PH $=5(\bullet)$ AND PHOTO-FENTON AT PH $=2.8(\circ)$ [137].

FIGURE 4.26. ELIMINATION OF FLOUROQUINOLONIC COMPONENTS (C1 AND C2) OBTAINED IN THE EEMPARAFAC MODEL VS TIME WITH SOLAR PHOTO-FENTON AT DIFFERENT WATER MATRICES. SW AT PH = 5 $(\diamond)$; SW AT PH $=2.8(\diamond)$; TW AT PH $=5(\boldsymbol{\Delta})$; TW AT PH $=2.8(\triangle)$; MQ AT PH $=5(\bullet)$ AND MQ AT PH $=$ $2.8(0)[137]$.

FIGURE 4.27. ANTIBACTERIAL ACTIVITY BEHAVIOUR OBTAINED WITH E. COLI FOR THE DIFFERENT TESTED PROCESSES IN MQ AT BOTH STUDIED PHS. PHOTOLYSIS AT PH = 5 (ם); PHOTOLYSIS AT PH = 2.8 ( $\square$ ); FENTON AT PH $=5(\diamond)$; FENTON AT PH $=2.8(\diamond)$, PHOTO-FENTON AT PH $=5(\bullet)$ AND PHOTO-FENTON AT $\mathrm{PH}=2.8(\circ)[137]$.

FIGURE 4.28. ANTIBACTERIAL ACTIVITY BEHAVIOUR OBTAINED WITH SOLAR PHOTO-FENTON WITHIN THE DIFFERENT TESTED WATER MATRICES. SW AT PH $=5(\diamond)$; SW AT PH $=2.8(\diamond)$; TW AT PH $=5(\boldsymbol{\Delta})$; TW AT $\mathrm{PH}=2.8(\triangle)$; MQ AT PH $=5(\bigcirc)$ AND MQ AT PH $=2.8(\circ)[137]$. 113

FIGURE 4.29. DEGRADATION KINETICS OF THE THREE STUDIED FQS ( 8 MG/L EACH) UNDER SIMULATED SUNLIGHT IRRADIATION (HN) AND ALSO WITH THE ADDITION OF $\mathrm{H}_{2} \mathrm{O}_{2} 125 \mathrm{MG} / \mathrm{L}\left(\mathrm{H}_{2} \mathrm{O}_{2} / \mathrm{HN}\right)$ AT INITIAL PH: A) 2.8, B)

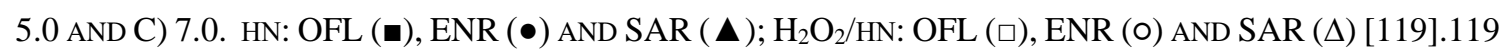
FIGURE 4.30. (PHOTO)-FENTON DEGRADATION KINETICS FOR THE THREE STUDIED FQS (8 MG/L EACH) AT INITIAL

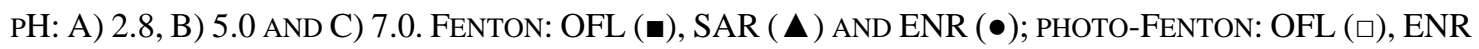
(0) $\operatorname{AND} \operatorname{SAR}(\Delta)[119]$ 121

FIGURE 4.31. MINERALIZATION PERCENTAGES FOR THE DIFFERENT STUDIED AOPS OVER THE FQ MIXTURE, OFL, ENR AND SAR (8 MG/L EACH) AT INITIAL PH VALUES 2.8, 5.0 AND 7.0. WHERE INDICATED, $\left[\mathrm{H}_{2} \mathrm{O}_{2}\right]_{0}=125$ $\mathrm{MG} / \mathrm{L}$ AND $[\mathrm{FE}(\mathrm{II})]_{0}=5 \mathrm{MG} / \mathrm{L}[119]$.

FIGURE 4.32. A) NORMALIZED EEMS AFTER THEIR PREPROCESSING WITH EEMLAB, AND B) 5-COMPONENT FINGERPRINTS FROM THE EEM-PARAFAC ANALYSIS [119].

FIGURE 4.33. OFL, ENR AND SAR (8 MG/L EACH) DEGRADATION WITH LIGHT IRRADIATION FOLLOWED WITH EEM-PARAFAC (5-COMPONENT MODEL) METHODOLOGY AT PH A) 2.8, B) 5.0 AND C) 7.0, AND WITH 
$\mathrm{H}_{2} \mathrm{O}_{2} 125 \mathrm{MG} / \mathrm{L}$ ADDITION AT PH D) 2.8, E) 5.0 AND F) 7.0. PARAFAC COMPONENT REPRESENTATION: C1

$(\boldsymbol{\bullet}), \mathrm{C} 2(\bullet), \mathrm{C} 3(\boldsymbol{\Delta}), \mathrm{C} 4(\diamond)$ AND C5 $(\triangleright)[119]$. 124

FIGURE 4.34. OFL, ENR AND SAR (8 MG/L EACH) DEGRADATION FOLLOWED WITH EEM-PARAFAC (5COMPONENT MODEL) METHODOLOGY WITH FENTON PROCESS AT PH A) 2.8, B) 5.0 AND C) 7.0, PHOTOFENTON AT PH D) 2.8, E) 5.0 AND F) 7.0. IN ALL CASES $\left[\mathrm{H}_{2} \mathrm{O}_{2}\right]_{0}=125 \mathrm{MG} / \mathrm{L}, \mathrm{AND}[\mathrm{FE}(\mathrm{II})]_{0}=5 \mathrm{MG} / \mathrm{L}$.

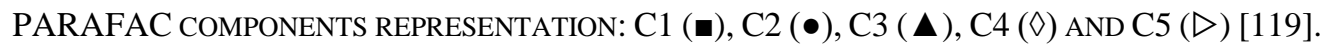
126

Figure 4.35. EFFECT OF Fe(II) (ADDED AS FESO $)_{4}$ AND FE(III) (ADDED AS FE(NO 3$)_{3}$ ), BOTH 1 MG/L, IN THE A) ABSORBANCE, AND B) FLUORESCENCE, SPECTRA OF ENR 1 MG/L CONTAINING ALSO $\mathrm{H}_{2} \mathrm{SO}_{4} 5$ MM AND $\mathrm{CH}_{3} \mathrm{OH}$ 0.25 M IN ALL CASES [119].

FIGURE 4.36. FLUORESCENCE QUENCHING PRODUCED BY FE(III) (FROM FE(NO $\left.\left.{ }_{3}\right)_{3}\right)$ TOWARDS FQs $(1.5 \mu \mathrm{M}$ EACH). THE EMPLOYED EXCITATION AND EMISSION WAVELENGTHS FOR EACH FQ WAS: EX. 270 NM, EM. 450 NM (ENR); EX. 290, EM. 507.5 NM (OFL); EX. 275 NM, EM. 460 NM (SAR). QUENCHING PRODUCED BY $\mathrm{NO}_{3}{ }^{-} 45$ MM (ADDED AS $\mathrm{KNO}_{3}$ ) WAS NEGLIGIBLE IN ALL CASES [119].

FIGURE 4.37. INFLUENCE OF IRON TOWARDS PARAFAC TIME-COURSE COMPONENTS SCORE VALUES. DARK-

FENTON PROCESS AT PH $=7.0$ : A) NORMAL MEASUREMENT, B) WITH IRON ELIMINATION [119]. 128

FIGURE 4.38. ANTIBACTERIAL ACTIVITY DECAY BY E. COLI NORMALIZED INHIBITION HALO DETERMINATIONS AND, AS INSERTED PLOT, THE SUMMATION OF COMPONENT SCORE VALUES $(\mathrm{C} 1+\ldots+\mathrm{C} 5)$ DECAY, ALSO NORMALIZED, OF THE FQS MIXTURE (8 MG/L EACH) AT PH 2.8 TREATED WITH LIGHT IRRADIATION ( 4 ), FENTON (ઐ) AND PHOTO-FENTON ( $\star$ ), IN THIS LAST TWO, $\left[\mathrm{H}_{2} \mathrm{O}_{2}\right]_{0}=125 \mathrm{MG} / \mathrm{L}$, AND $[\mathrm{FE}(\mathrm{II})]_{0}=5 \mathrm{MG} / \mathrm{L}$ [119].

FIGURE 4.39. (F)QS, 3 MM EACH, REMOVALS WITH SOLAR PHOTO-FENTON ([FE $\left.{ }^{2+}\right]_{0}=5$ MG/L AND ADDITIONS OF $\left.\left[\mathrm{H}_{2} \mathrm{O}_{2}\right]=5 \mathrm{MG} / \mathrm{L} \mathrm{EVERY} \mathrm{T}_{30 \mathrm{~W}}=12.5 \mathrm{MIN}\right)$ : A) MQ PH 5.0; B) SW PH 5.0; C) SWW PH 5.0; D) SWW NATURAL PH (CA. 7.5)

FIGURE 4.40. (F)QS, 3 MM EACH, REMOVALS WITH SOLAR PHOTO-FENTON ([FE $\left.{ }^{2+}\right]_{0}=5$ MG/L AND ADDITIONS OF $\left[\mathrm{H}_{2} \mathrm{O}_{2}\right]=5 \mathrm{MG} / \mathrm{L}$ EVERY T30W $=12.5 \mathrm{MIN}$ ) WITH ADDITION OF $20 \mathrm{MG} / \mathrm{L}$ OF OMW-HLS: A) MQ PH 5.0; B) SW PH 5.0; C) SWW PH 5.0; D) SWW NATURAL PH (CA. 7.5).

FIGURE 4.41. MEASURED EEM FOR THE DIFFERENT (F)QS (FIRST LINE) AND FROM THEIR MIXTURE AFTER DIFFERENT REACTION TIME INTERVALS AND WATER MATRICES: A) T30w $=0$ MIN IN MQ, B) MQ T30W $=14.2$ MIN, C) SW T30W $=58$ MIN, D) SWW T30W $=54$ MIN, AND E) SWW NATURAL PH T $30 \mathrm{~W}=58 \mathrm{MIN}$. 137

FIGURE 4.42. EEM-PARAFAC 6-COMPONENT MODEL FINGERPRINTS. 138

FIGURE 4.43. (F)QS, 3 MM EACH, REMOVALS WITH SOLAR PHOTO-FENTON ( $\left[\mathrm{FE}^{2+}\right]_{0}=5 \mathrm{MG} / \mathrm{L}$ AND ADDITIONS OF $\left[\mathrm{H}_{2} \mathrm{O}_{2}\right]=5 \mathrm{MG} / \mathrm{L}$ EVERY T T3w $=12.5 \mathrm{MIN}$ ) MONITORED WITH EEM-PARAFAC: A) MQ PH 5.0; B) SW PH 5.0; C) SWW PH 5.0; D) SWW NATURAL PH (CA. 7.5).

FIGURE 4.44. EEM-PARAFAC SCORES FROM NON-CALIBRATED FOUND COMPONENTS IN THE DIFFERENT STUDIED WATER MATRICES, A) X1 AND B) X2. 140

FIGURE 4.45. TBZ 3 MM FENTON DEGRADATION IN MQ AT PH 5.0, EMPLOYING 15 MM OF FE ${ }^{2+}$ AND 5 MG/L EACH 25 MIN DOSAGE OF $\mathrm{H}_{2} \mathrm{O}_{2}$, IN ABSENCE AND PRESENCE OF THE (F)QS MIXTURE, OFL, CIP, ENR, OA AND FLU, EACH IN CONCENTRATION 3 MM. 141

FIGURE 4.46. EEM-PARAFAC MODEL CONTAINING FENTON DEGRADATION OF TBZ 3 MM AND THE TESTED (F)QS: A) 7-COMPONENT MODEL; B) SCORES BEHAVIOUR FOR EACH COMPONENT...... 142 
FIGURE 4.47. SAMPLING SITES FROM SMAT DWTP, A) SCHEME, B) AIR PICTURE. 145

FIGURE 4.48. FINGERPRINTS FROM THE 3-COMPONENT PARAFAC MODEL. EACH COMPONENT, C1, C2 AND C3, CAN BE CORRELATED WITH HA-L, TRY-L AND TYR-L SUBSTANCES, RESPECTIVELY. 148

FIGURE 4.49. PARAFAC COMPONENTS EVOLUTION ALONG THE DWTP, WHITE COLUMNS FOR HA-L COMPONENTS (C1), BLUE FOR TRY-L (C2) AND BLACK FOR TYR-L (C3). AS INSERT BELOW, THE CHANGE OF PARAFAC SCORE VALUES (NORMALIZED), TAKING THE VALUES FROM SITE E AS INITIAL. HA-L REPRESENTED BY WHITE SQUARES ( $\square$ ) AND TRY-L BY BLUE SQUARES ( $\bullet$ ). TYR-L WERE NOT REPRESENTED IN THE LATTER. ERROR BARS WERE CALCULATED AS THE STANDARD DEVIATION BETWEEN REPLICATES.. 149 FIGURE 4.50. OBTAINED VALUES IN EACH SAMPLING POINT FOR: A) UVA; B) NPOC. VALUES REPRESENT THE AVERAGE OF CONSECUTIVE MEASUREMENTS, AND ERROR BARS THE ASSOCIATED UNCERTAINTY..... 151

FIGURE 4.51. SUMMARY OF THE STUDIED PROCESSES IN THIS WORK. 155

FigURE 4.52. PNBA REDUCTION (A) AND GENERATED PABA (B) IN NW AT PH 3.0 WITH DIFFERENT AMOUNTS OF MZVI (G/L): $0.056(\bullet), 0.56(\triangle), 1.4(\bullet), 2.8(\nabla)$ AND $4.2(\bullet)$

FIGURE 4.53. DisSOLVED OXYGEN CONCENTRATION DURING PNBA 6 MM REDUCTION IN NW WITH 1.4 G/L OF MZVI AT INITIAL PH 3.0.

FIGURE 4.54. THREE CONSECUTIVE REDUCTIONS OF PNBA $6 \mu \mathrm{M}$ (ADDITIONS EACH 120 MIN) IN NW WITH 1.4 G/L OF MZVI AND INITIAL PH 3.0. 158

FIGURE 4.55. PNBA $6 \mu \mathrm{M}$ REDUCTION AT INITIAL PH 3.0 WITH $1.4 \mathrm{G} / \mathrm{L}$ MZVI IN DIFFERENT WATER MATRICES AT 180 MIN: A) RELEASED FE (MEASURED AS TOTAL AND FILTERED) B) PH. 159

FIGURE 4.56. WATER MATRIX EFFECT. PNBA $6 \mu$ M REDUCTION WITH MZVI 1.4 G/L AT INITIAL PH 3.0 IN DW, A) PNBA AND B) PABA KINETICS, RESPECTIVELY. SYMBOLS ARE REPRESENTED BY: DW ALONE ( $\square)$, $\mathrm{DW}+\mathrm{CL}^{-} 212 \mathrm{MG} / \mathrm{L}(\bullet), \mathrm{DW}+\mathrm{SO}_{4}{ }^{2-} 270 \mathrm{MG} / \mathrm{L}(\boldsymbol{\bullet}), \mathrm{DW}+\mathrm{TIC} 34 \mathrm{MG} / \mathrm{L}(\boldsymbol{\Delta}), \mathrm{AND}$ DW+N 2 PURGING (沦). 160

FIGURE 4.57. KINETIC FORMATION OF TWO UNKNOWN COMPOUNDS, CALLED X1 AND X2, OBSERVED IN THE CHROMATOGRAMS DURING PNBA $6 \mu$ M REDUCTION WITH 1.4 G/L MZVI AT INITIAL PH 3.0 IN DW UNDER AEROBIC ( $\square$ AND • FOR X1 AND X2, RESPECTIVELY) AND ANAEROBIC ( $\square$ AND $\circ$ FOR X1 AND X2, RESPECTIVELY) CONDITIONS. 160

FIGURE 4.58. $\mathrm{H}_{2} \mathrm{O}_{2}$ CONSUMPTION DURING FENTON OXIDATION EXPERIMENTS, SEPARATING THE MZVI PREVIOUS DIFFERENT $\mathrm{H}_{2} \mathrm{O}_{2}$ CONCENTRATIONS, $10 \mathrm{MG} / \mathrm{L}(\circ), 25 \mathrm{MG} / \mathrm{L}(\triangle)$ AND $50 \mathrm{MG} / \mathrm{L}(\diamond)$, AS WELL AS THE ONE CONTAINING THE MZVI $1.4 \mathrm{G} / \mathrm{L}$ WITH $\mathrm{H}_{2} \mathrm{O}_{2} 50 \mathrm{MG} / \mathrm{L}(\oplus)$

FiguRE 4.59. REDUCTION OF PNBA 60 MM IN NW AT INITIAL PH 3.0 WITH 1.4 G/L OF MZVI, FOLLOWED BY THE DIFFERENT TESTED FENTON OXIDATIONS. WHEN NEEDED, 10 MIN FOR MZVI SEPARATION TOOK PLACE. . 162 FIGURE 4.60. FENTON OXIDATION OF THE SUPERNATANT ([PABA] $\left.=50 \mathrm{MM},\left[\mathrm{FE}_{\mathrm{TOTAL}}\right]=55 \mathrm{MG} / \mathrm{L}, \mathrm{PH}=7.3\right) \mathrm{WITH}$ $50 \mathrm{MG} / \mathrm{L} \mathrm{OF} \mathrm{H}_{2} \mathrm{O}_{2}$, AND $50 \mathrm{MM}$ OF PNBA (ADDED). THEORICAL PNBA DEGRADATION RATE[62] HAS BEEN ALSO INSERTED IN THE GRAPH. SYMBOL REPRESENTATION HAS BEEN GIVEN BY: • (PABA), • (PNBA) AND

$\Delta$ (THEORICAL PNBA DEGRADATION RATE). 163

FIGURE 4.61. MZVI REUSE FOR NEW PNBA $60 \mu \mathrm{M}$ SOLUTIONS PREPARED IN NW WITH INITIAL PH 3.0 AND 7.0. 10 MIN FOR MZVI SEPARATION PREVIOUS H2O2 50 MG/L ADDITION IN THE SUBSEQUENT FENTON STEP: A) PNBA DECAY AND PABA FORMATION; B) TOTAL DISSOLVED IRON AND PH ARE ALSO SHOWN. 164 
FIGURE 4.62. FiRST PNBA 60 MM REDUCTION AT PH 3.0 WITH 1.4 G/L OF MZVI IN NW, AND ITS SUBSEQUENT REUSES AT PH 7.0. 10 MIN BETWEEN EACH CYCLE WAS REQUIRED FOR MZVI DECANTATION AND SUPERNATANT SEPARATION.

\section{LIST OF TABLES}

TABLE 1.1. MOLECULAR STRUCTURE AND REPORTED PKA VALUES [43,56] FOR INVESTIGATED (FLUORO)QUINOLONES IN THIS PHD THESIS.

TABLE 1.2. KINETIC RATE CONSTANTS OF HO ${ }^{\bullet}$ WITH TYPICAL WATER CONSTITUENTS AT $25^{\circ} \mathrm{C}$ AND PH 6-8 $[62,65]$ .19

TABLE 1.3. MOLECULAR STRUCTURES OF MENTIONED CHELATING AGENTS.

TABLE 2.1. $\mathrm{FE}^{2+}$ SPECTROPHOTOMETRIC DETERMINATION, CHELATING AGENTS' MOLECULAR STRUCTURES. ........51 TABLE 4.1. ELUCIDATED MAJOR PHOTOPRODUCTS IN BOTH SYSTEMS ENR AND FE ${ }^{\text {III-ENR }} 3$ AND AT BOTH STUDIED PHS. * INDICATED FOR THOSE WHO WERE NOT FOUND IN BIBLIOGRAPHY [118] .......................................... 82

TABLE 4.2. UVC AND MAGNOX/UVC TERTIARY TREATMENT COMPARISON [187]. . .99

TABLE 4.3. CORE CONSISTENCY DIAGNOSTIC (CORCONDIA) VALUES FOR THE DIFFERENT TESTED PARAFAC MODELS [119]. 118

TABLE 4.4. MODEL RESIDUALS DISTRIBUTION [119]. 118

TABLE 4.5. TOTAL IRON AND PH VALUES CHANGES AFTER PHOTO-FENTON PROCESSES [119]. 120

TABLE 4.6. SWW CONSTITUENTS 131

TABLE 4.7. CALIBRATION CURVES LINEAR REGRESSIONS (ONLY THREE STANDARDS EACH: 0.5, 1.5 AND 3 MM IN MQ) EMPLOYING THE OBTAINED 6-COMPONENT MODEL FITTING THE INDIVIDUAL EEM OF EACH COMPOUND. 138

TABLE 4.8. CORCONDIA OBTAINED RESULTS FOR EACH TESTED PARAFAC MODEL. 146

TABLE 4.9. MEASURED, MODELLED AND RESIDUALS FROM SOME EXAMPLE SAMPLING POINTS OBTAINED FOR THE

3-COMPONENT PARAFAC MODEL. 147

TABLE 4.10. NATURAL WATER CHARACTERIZATION. 154 


\section{ABBREVIATIONS}

\begin{tabular}{|c|c|}
\hline $\operatorname{AOP}(\mathbf{s})$ & Advanced Oxidation Process(es) \\
\hline CEC(s) & Contaminant(s) of emerging concern \\
\hline CFU & Colony-forming unit \\
\hline CIP & Ciprofloxacin \\
\hline COD & Chemical oxygen demand \\
\hline CPC & Compound Parabolic Collector \\
\hline DBP & Disinfection by-products \\
\hline DOC & Dissolved organic carbon \\
\hline DOM & Dissolved organic matter \\
\hline DW & Demineralised water \\
\hline DWTP & Drinking water treament plant \\
\hline EDDS & Ethylenediamine-N,N'-disuccinic acid \\
\hline EDTA & Ethylenediaminetetraacetic acid \\
\hline EEM & Fluorescence excitation-emission matrix \\
\hline ENR & Enrofloxacin \\
\hline EPA & United States Environmental Protection Agency \\
\hline ESI & Electrospray ionization \\
\hline $\mathbf{E U}$ & European Union \\
\hline FACSA & Sociedad de Fomento Agrícola Castellonense S.A. \\
\hline FAO & Food and Agriculture Organization of the United Nations \\
\hline FLU & Flumequine \\
\hline $\mathbf{F Q}(\mathbf{s})$ & Fluoroquinolone(s) \\
\hline GUI & Graphical user interface \\
\hline HA-L & Humic acid-like substances \\
\hline HLS & Humic-like substances \\
\hline HPLC & High performance liquid chromatography \\
\hline IFE & Institute for Energy Technology \\
\hline IUPAC & International Union of Pure and Applied Chemistry \\
\hline JRC & Joint Research Center \\
\hline LMCT & Ligand to metal charge transfer \\
\hline MQ & Ultrapure water \\
\hline
\end{tabular}




\begin{tabular}{|c|c|}
\hline MS & Mass spectrometry \\
\hline NOM & Natural organic matter \\
\hline NPOC & Non-purgable organic carbon \\
\hline NTA & Nitrilotriacetic acid \\
\hline NW & Natural water \\
\hline $\mathbf{O A}$ & Oxolinic acid \\
\hline OFL & Ofloxacin \\
\hline OMW & Olive mill wastes \\
\hline PABA & p-aminobenzoic acid \\
\hline PARAFAC & Parallel factor analysis \\
\hline PCA & Principal component analysis \\
\hline PNBA & p-nitrobenzoic acid \\
\hline PSA & Plataforma Solar de Almería \\
\hline ROS & Reactive oxygen species \\
\hline SAR & Sarafloxacin \\
\hline SMAT & Società Metropolitana Acque Torino S.p.A. \\
\hline SW & Salty water \\
\hline SWW & Simulated wastewater \\
\hline TBZ & Thiabendazole \\
\hline TIC & Total inorganic carbon \\
\hline TOC & Total organic carbon \\
\hline Try-L & Tryptophan-like substances \\
\hline TW & Tap water \\
\hline Tyr-L & Tyrosine-like substances \\
\hline UCA & Université Clermont Auvergne \\
\hline UNESCO & United Nations Educational, Scientific and Cultural Organization \\
\hline UPV & Universitat Politècnica de València \\
\hline UV & Ultraviolet light \\
\hline UVa & Ultraviolet light absorbance $254 \mathrm{~nm}$ \\
\hline WHO & World Health Organization \\
\hline (M)WWTP & (Municipal) wastewater treatment plant \\
\hline$(\mathbf{m}) Z V I$ & Zerovalent iron (microparticles) \\
\hline
\end{tabular}




\section{CHAPTER 1}

INTRODUCTION 



\section{Introduction}

\section{1. $\quad$ Preface}

This $\mathrm{PhD}$ is part of project AQUAlity, a multidisciplinary, interdisciplinary, and crosssectoral European Training Network, devoted to the study of contaminants of emerging concern removal from water. This project has received funding from the European Union's Horizon 2020 research and innovation programme under the Marie Skłodowska-Curie (MSCA) - Innovative Training Network (Call: H2020-MSCA-ITN-2017) grant agreement $\mathrm{N}^{\circ}$ 765860 .

The research tasks shown in this $\mathrm{PhD}$ Thesis were developed in four institutions/companies, being Universitat Politècnica de València (UPV) - Alcoy campus (Alcoy, Spain) the host institution where most of the works were conceptualized, organized and performed. The other three institutions were: Sociedad de Fomento Agrícola Castellonense S.A. (FACSA) (Alhama de Murcia, Spain), Université Clermont Auvergne (UCA) (ClermontFerrand, France) and CIEMAT-Plataforma Solar de Almería (PSA) (Almería, Spain). From the beginning to the end, the whole activities were always supervised by Dr. Antonio Arques (UPV) as well as by Dr. Isabel Oller (PSA) and Dr. Carlos Escudero-Oñate (Institute for Energy Technology, IFE) (Kjeller, Norway).

The $\mathrm{PhD}$ Thesis has been organized into six chapters: Introduction, Experimental, Objectives, Results and Discussion, Conclusions and References. In the first chapter, the main relevant concepts are presented. On one hand, the issues associated with water reclamation, the legal framework of contaminants of emerging concern (CECs) and a summary on existing water treatment technologies with focus on advanced oxidation processes (AOPs), particularly photo-Fenton, are presented. On the other hand, the chapter ends with the concepts related to fluorescence spectroscopy and parallel factor analysis (PARAFAC). Chapter 2 intends to briefly describe the fundamentals behind the employed instruments and the basis of the analytical methodologies applied, Chapter 3 briefly summarizes the main objectives pursued, and Chapter 4 shows all the published, sent, and recently finished research works. For those who have been previously published in peer-review journals, co-authors and journal's names are specified. Finally, Chapters 5 and 6 show the overall conclusions and employed references, respectively. 
As stated by the AQUAlity project, results reflect only the authors' view, and the Agency is not responsible for any use that may be made of the information it contains.

\subsection{Is the use of reclaimed water still optional?}

\subsubsection{Water scarcity: future global scenario}

Despite the fact that annual global population growth is in decreasing trend, with an actual $1.04 \%$ [1], todays' water demand will not satisfy future needs. The World Bank reported - twenty years ago already - that within the next century, the quantity of available water must increase between $25-60 \%$ [2], becoming water stress more common in the upcoming years.

According to the UNESCO World Water Report (2019), worldwide water use has been rising at a steady $1 \%$ per year since the 1980 s, mainly attributed to the increasing water demand from developing countries (which is still utterly below from the one from developed countries), the global consumption patterns growth, and the global population increment. The aforementioned global water demand is expected to remain constant, at least, until 2050, which means that the amount of water used will be a $20-30 \%$ greater than the one of today. As a consequence, estimations for 2050 indicate that $45 \%$ of the global gross domestic product and $40 \%$ of the global grain production will be at risk, there will be a likelihood increment of potential armed conflicts, and, therefore, an overall exacerbation of already rising global inequalities [3].

Based on Figure 1.1, when analysing the renewable water sources flows per capita (estimated from rivers and groundwater sources), the European Union (EU) has consumed the $15 \%$ of them from 1962 to 2014 . This number might seem low if we compare it to the one of Brazil (the country with the highest renewable water sources flows of the world), which had a dramatic $62 \%$ decrease in the same period. However, nowadays this country still counts with ca. $3 \times 10^{4} \mathrm{~m}^{3} /$ capita, whereas for the whole EU is approximately one order of magnitude lower, $3 \times 10^{3} \mathrm{~m}^{3} /$ capita. Evidently, water scarcity represents a more drastic concern for arid regions, such as the Middle East, which, besides the economic water scarcity (lack of water management infrastructure), up to date counts with ca. $5 \times 10^{2} \mathrm{~m}^{3} /$ capita [4]. 


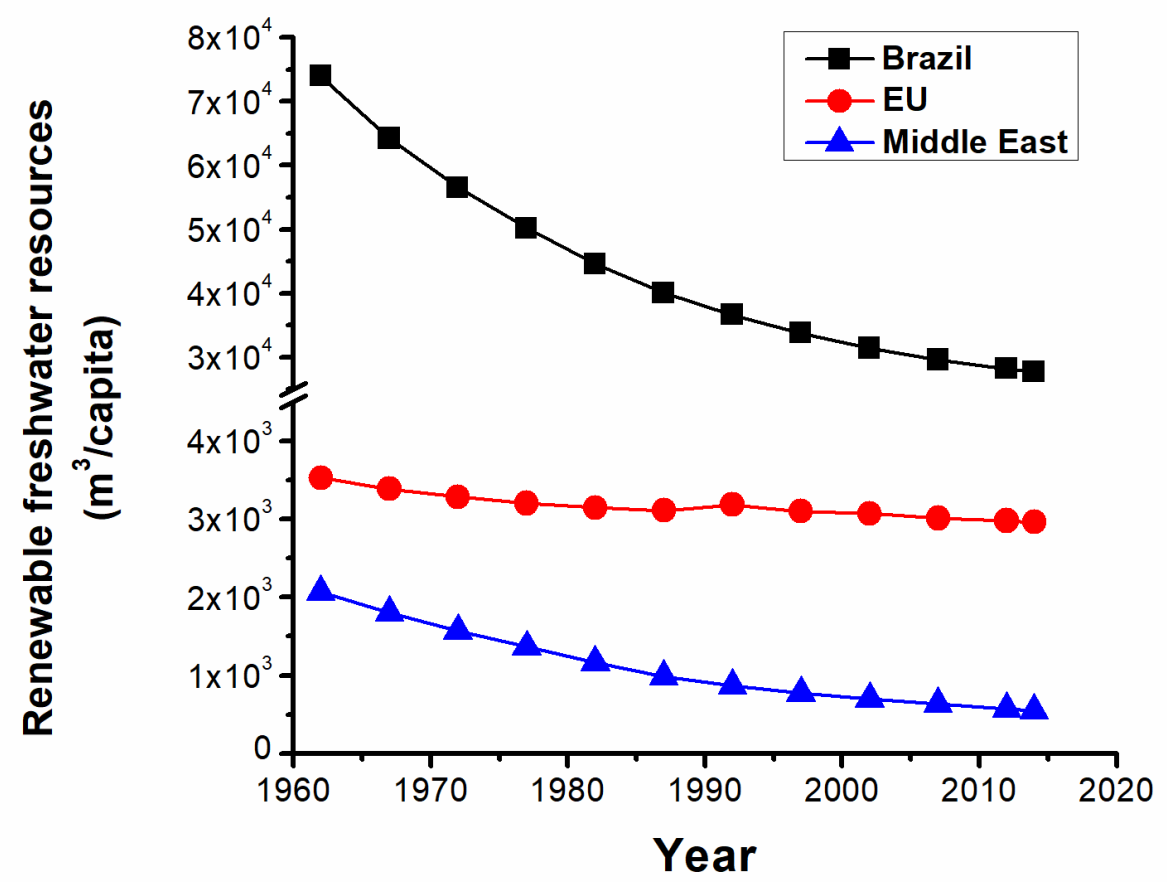

Figure 1.1. Renewable freshwater resources per year for Brazil, EU and Middle East. Data obtained from Our World in Data accessed on November 2020 [4].

In line with the above mentioned statements, it was not surprising when, at the beginning of December 2020, it was announced - for the first time in history - that water as such was going to be traded in the New York Stock Exchange [5]. This idea is, however, mainly behind California's water market. Although this territory leads the list of the top driest states in United States, it is one of the biggest productive agricultural regions on Earth, being also the most populous state in the country; hence, water is an already extremely valuable resource for the area. Nevertheless, differently from other commodities such as oil or coal, water has the advantage of having reuse potential, opening the door to circular economy-related business models.

\subsubsection{Wastewater reclamation}

In the EU, up to date only $3 \%$ of the total tap water production is used for drinking. The remaining $97 \%$ is employed for flushing the toilets, dish and car washing, or irrigation purposes [6]. These are just a few examples of operations where non-potable water could be easily tolerable, aiming to control the quantity and quality of the supplied water according to its application, hence, prioritizing its use [7]. Therefore, smarter and holistic water management tools are urgently required to efficiently manage this precious resource.

Water coming from urban uses and the rain, prior to discharge in the natural environment, is delivered to facilities called wastewater treatment plants (WWTPs). These facilities consist 
of three key steps: i) pre-treatment, where the heavier solids, such as sand, tree branches or paper, are separated, ii) primary treatment, based on a decantation tank where compounds with higher density than water precipitate, whereas the ones with lower density (i.e. fats) are skimmed off in the surface, and iii) secondary treatment, being the most common the one based on activated sludge (a mixture of bacteria and protozoa) biological reactors, where biodegradable urban wastes, such as sugars, soap or food wastes are degraded [6]. The separated primary and secondary sludge is generally delivered to an anaerobic digestion process, where methane is released and valorized for energy-related purposes. The final effluent can be either discharged or reused as reclaimed water.

Reclaimed water finds an excellent niche for reuse in agriculture, an activity that nowadays consumes water quantities as high as $70 \%$ of global freshwater withdrawals worldwide $[4,8]$. Comparable to the case of California named in the previous section, Spain's southeast region has agriculture as one of the most important economic activities. Due to the arid environment, crop irrigation becomes threatened by prolonged drought episodes that make water an expensive and scarce critical resource. The need for water leads to overexploitation of groundwater sources, which have as result the aquifer salinization [9]. This problem also becomes relevant for water-intensive crops, such as avocado or olives, whose water footprints levels are among the highest of all crops [10,11].

According to the U.S. Environmental Protection Agency (EPA), Guidelines for Water Reuse (2012) [12], top-five worldwide ranking within reclaimed water use capacity are, United States, China, Saudi Arabia, Australia and Spain, being the main worldwide reclaimed water applications agricultural irrigation (32\%), landscape irrigation (20\%) and industrial uses $(19 \%)$. Furthermore, the main horizon will be to restore wastewater with enough quality standards to be potable. In this regard, as an interesting example, it can be mentioned the case of the International Space Station, where astronauts have been drinking urine-recycled water since 2009 [6].

However, there are still several obstacles to overcome, such as associated costs, since reclaimed water is not cheaper than freshwater. In fact, it is often subsidized to be priced just below the one of drinking water because it is required to promote its use [12]. On the other hand, using a more attractive language during outreach activities becomes also important; replacing terminology such as "wastewater reuse" for "recycled water" or "new water", as well as developing specific certifications for products that have employed reclaimed water along 
their production can favour their consumption against those employing conventional freshwater (analogous to "organic", "vegan" or "animal welfare" certificates that are being used nowadays in some merchandising). One must bear in mind that in this regard, the food industry exhibits large water footprints, being the meat industry (mainly beef) the one with the highest water withdrawal from all [12].

Finally, from the chemical point of view, setting minimum water quality standards is also required, thus implicating significant efforts, and a huge amount of research to efficiently decontaminate water that today can actually be considered as clean [13]. In this regard, there are two main water constituents to explain: natural organic matter and contaminants of emerging concern.

\subsection{Compounds of concern towards water treatment}

\subsubsection{Natural organic matter}

The presence of natural organic matter (NOM) in water is a key parameter to be considered when evaluating treatment technologies efficiency, and it is defined as the mixture of complex macromolecules coming from the decomposition and excretion from algae, plants and animals.

NOM is present in various environments, such as soil, groundwater, rivers and oceans, playing vital roles as carbon sink between vegetation and atmosphere and exerts a large influence in aqueous ecosystems, e.g. affecting the regulation of nutrients' cycle or the microbial loop [14]. Its composition is highly variable, depending on countless factors, such as its origin (allochthonous or autochthonous), agglomeration, $\mathrm{pH}$, temperature, presence of microbial and/or photolytic degradation processes, or even anthropogenic activity (e.g. cropping, afforestation or interaction with inorganic and organic pollutants) [15]. Nevertheless, it basically consists of a complex mixture of derivatives of humic and fulvic acids (ca. $50 \%$ of total NOM), carbohydrates, proteins, low molecular weight organic acids and other compound classes. Therefore, NOM molecular weight can range from $100-2000 \mathrm{Da}$, to even $1 \times 10^{5} \mathrm{Da}$ (colloidal size range).

NOM can be classified as particulate organic matter and dissolved organic matter (DOM) depending on if it is retained or not in $0.45 \mu \mathrm{m}$ pore size filters, respectively. The proportion of each fraction, dissolved and particulate, is usually linked to the effluent flow, seasonal variations or algal blooms. Moreover, NOM can be also classified as biodegradable and non- 
biodegradable [15]. Towards water treatment analysis implications, the most relevant NOM fraction to focus on is the dissolved one.

DOM monitoring within water treatment is essential due to its many detrimental associated issues. For example, at drinking water treatment plants (DWTPs), we can cite the generation of genotoxic and carcinogenic disinfection by-products (e.g. trihalomethanes or haloacetic acids) occurring after oxidation by chlorine-based reagents [16], microorganism proliferation [17], or even enhancement of membrane fouling [18], all of which result in an overall increase of water production costs. Besides, due to the hydroxyl, carboxyl and, sometimes, amino groups present in DOM, they can interact with pollutants, modifying their mobility, hence, being a plausible risk of re-dissolution of, for example, heavy metals [14].

Despite the paramount environmental relevance of DOM, up to date, its characterization is still challenging. The main techniques employed nowadays involve: i) absorbance and fluorescence spectroscopy to rapidly know in which type of DOM the sample is enriched in, ii) size-exclusion chromatography, dialysis and/or ion exchange resins, to isolate the different types of DOM, and iii) Fourier-transformed infrared spectroscopy, nuclear magnetic resonance (mainly ${ }^{13} \mathrm{C}$ ), pyrolysis and mass spectrometry, to elucidate plausible functional groups from the isolated DOM's fractions [19]. The scheme from Figure 1.2 briefly summarizes a classification of DOM types according to their size, polarity and charge.

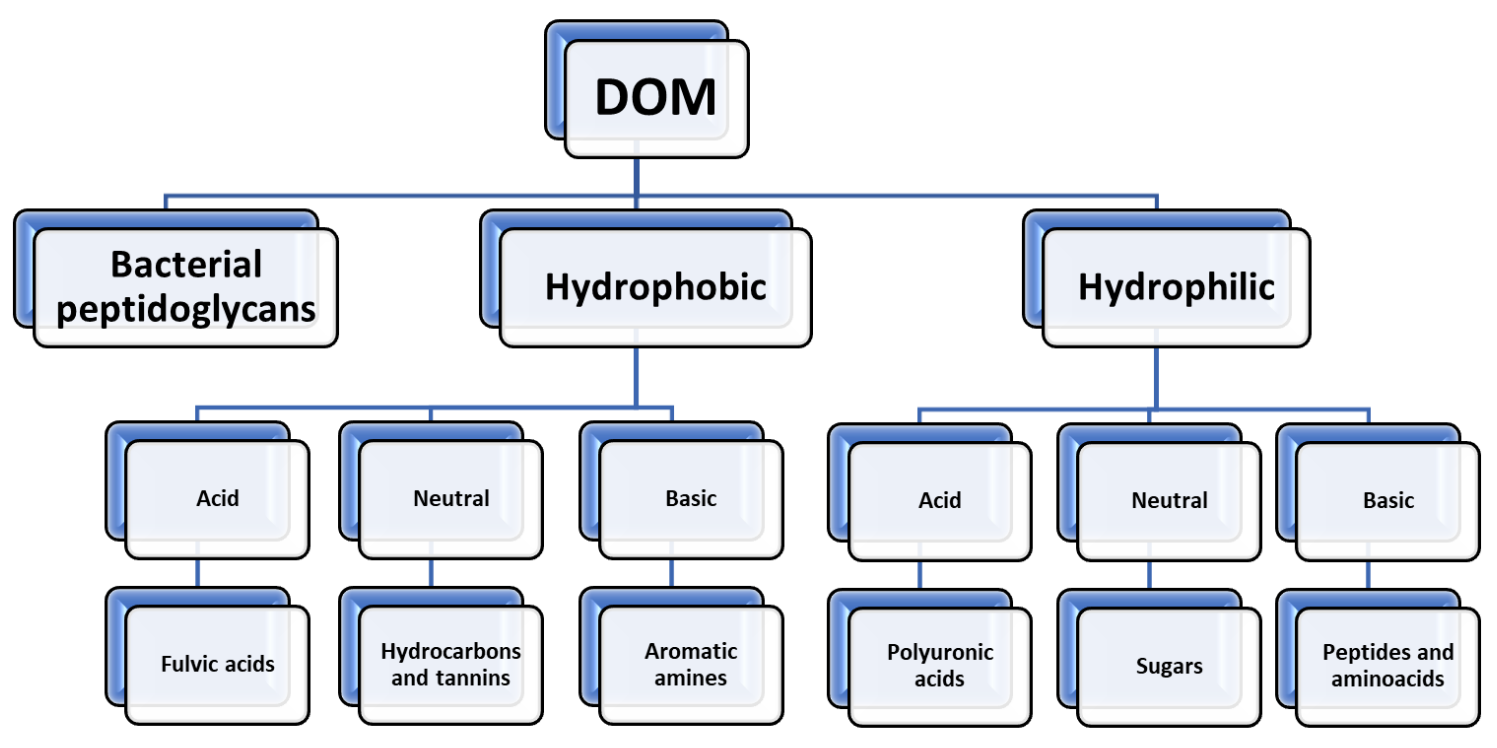

Figure 1.2. Classification of the different types of DOM based on the review published by Leenheer and Croué, 2003 [15]. 
Due to the presence of condensed aromatic moieties, DOM exhibits a rich, complex and wide photochemistry. Ultraviolet absorbance at $254 \mathrm{~nm}$ is one of the main methods to quantify DOM spectroscopically, as well as fluorescence excitation-emission matrices (see later section 1.7.2.2.1). Due to its variety and complexity, DOM presents a wide range of plausible absorption and fluorescence maximums. On the other hand, DOM is also known to act as photosensitizer (see later section 1.5.2), a substance that after being irradiated can generate reactive oxygen species (ROS), which, as the name suggests, are powerful oxidant agents able to degrade other substances in water as well as the own DOM. In addition, it also works as UV filter for microorganisms, enhancing their growth [14].

Besides DOM, natural water such as river, oceans and lakes, and mainly urban wastewaters, have also the presence of other chemical substances only originated from human activity, the so-called contaminants of emerging concern.

\subsubsection{Contaminants of emerging concern}

The influent of urban WWTPs reflects the social consumption patterns. As shown in the review of Petrie et al., 2015, antihistamines concentration rises during the spring season, whereas nasal decongestants (i.e. pseudoephedrine) do it in the winter season. Something similar happens with antibiotics, showing concentration peaks within 7 - 9 AM, in agreement with the first-morning urine [20]. Even illegal drugs, such as cocaine or MDMA (ecstasy), exhibited maximum concentrations right after-curiously-music festivals as well as on Friday and Saturday. Moreover, due to the recent COVID-19 pandemic, it can be anticipated that quaternary ammonium compounds from surface disinfectant products will notably increase their loads in urban wastewater compared to past years [21].

Personal care products, pharmaceuticals, food additives, pesticides, insecticides, flame retardants, among others, are just partially degraded in WWTP, and hence, they enter into the environment. In this regard, a large number of scientific papers have pointed out the presence of these substances in lakes, rivers and oceans all over the globe, in concentrations that vary from $\mathrm{ng}-\mu \mathrm{g} / \mathrm{L}$, reaching in some extreme cases, the level of $\mathrm{mg} / \mathrm{L}$ [20]. The ecological damage the continuous release of these chemicals have into the environment is still unknown, although many of them proved to be hazardous even at low concentrations [22]. Due to these reasons, these compounds have been received the name of contaminants of emerging concern (CECs).

In the EU, CECs' water policy legislation started with the first prioritization substances list in 2001, containing 33 compounds (mainly heavy metals and pesticides), reviewed again 
in 2008, and amended in 2013 [23]. The latter water directive includes now 45 chemical substances, with an additional statement indicating that the EU Commission must include a watch list containing a maximum of 10 relevant CECs for their Union-wide monitoring [24]. In this regard, a thorough report has been recently reported by the Joint Research Centre (JRC), monitoring 10 potential substances (i.e. diclofenac, ibuprofen, ciprofloxacin) in raw and treated urban wastewater along EU [25].

In this regard, it just entered in force the revised EU directive 2020/2184 the $12^{\text {th }}$ January 2021 for drinking water, which stipulates the maximum tolerable amounts of some CECs, such as PFAS $(<0.5 \mu \mathrm{g} / \mathrm{L})$ or bisphenol A $(<2.5 \mu \mathrm{g} / \mathrm{L})$, and Members State will have two years to transpose it into their respective national legislation [26].

\subsubsection{Environmental implications of CECs}

Regardless CECs might seem harmless due to their presence in low concentrations, the associated hazardous issues are still under investigation and reported results are showing the opposite. For instance, when using reclaimed water for irrigation purposes, it was seen that CECs are uptaken and bioconcentrated, being celery, lettuce and spinach those with the highest potential uptake [27]. This is of particular concern with wastewater containing antibiotics, as they can enhance the proliferation of antibiotic-resistant bacteria.

On the other hand, regarding treated wastewater discharge in the natural environment, this might produce a different toxicological effect to the aquatic organisms, such as acute or chronic toxicity as well as (trophic) bioaccumulation. Unexpected aquatic-biota behaviour changes have also been reported. An interesting work published in Science by Brodin et al., 2013, showed that ca. $2 \mu \mathrm{g} / \mathrm{L}$ of benzodiazepine (anxiolytic), decreased fish feeding rate and made them more active and less "social" with other fishes from the same species [28]. In addition, it was also correlated with pollutant concentration, since higher benzodiazepine concentration (ca. $1 \mathrm{mg} / \mathrm{L}$ ) enhanced these observations, as well as made fish bolder, hence losing fear to explore new areas, increasing the risk of being eaten by possible predators. Similarly in another study employing sertraline (antidepressant) in a range from $0.1-300 \mu \mathrm{g} / \mathrm{L}$, altered fish feeding rates were observed [29]. Indeed, these results indicate that drastic changes within the predator-prey aquatic system might happen — or already be happening — due to CECs environmental presence in trace amounts, leading to likelihood damage of an entire ecosystem in the worst possible scenarios. 
Even though they can be removed to some extent at WWTP, this does not necessarily imply a toxicity reduction. CECs mineralization in WWTP is negligible, and the degradation by-products that arise from the treatments could exhibit even higher toxicity than the parent compound. In addition to this, the hazards of CECs are also dependent on a large and complex set of interactions with other CECs and/or compounds commonly found in water bodies, such as NOM, anions and metals [20,30]. In this sense, CECs frequently undergo adsorption on organic matter particles, representing a challenge to the analytical determination of these pollutants in water. If the effect of adsorption is not properly addressed, misinterpretations in the current load of CECs in the influent stream of the WWTP take place and therefore the reported degradation efficiency of CECs is biased towards overestimation [31]. Since the WWTP sludge can be used as fertilizer, there might be a transfer of CECs to soil and, consequently, to groundwater or crops, implicating analogous risks to the ones previously mentioned.

In natural effluents, CECs also undergo degradation through different routes. These substances can be degraded by microorganisms (biodegradation) or excreted by aquatic organisms (metabolization), as well as transformed through hydrolysis and photolysis. Again, in any case, CEC removal means a hazard decrease as partial degradation processes enhances the variety of chemicals present in water, hence, producing serious difficulties towards policymaking.

Tackling the aforementioned challenges would involve a set of different actions such as: I) promoting education to the public about the cycle and risks of CECs, II) developing biodegradable chemicals, and III) use of advanced effluent treatments to ensure safe reutilization or environmental discharge.

This $\mathrm{PhD}$ Thesis especially focuses on the degradation of fluoroquinolones, a class of synthetic antibiotics, described in the subsequent subsections with a previous general scenario of the concerns related to antibiotics.

\subsubsection{Antibiotics}

Households, hospitals, animal farms and aquaculture facilities are among the main sources of antibiotics released to the environment. As mentioned above, the main concern of antibiotics is not only their toxicological effects per se, but the likelihood of the development of antibiotic-resistant genes and bacteria within WWTPs, which can become a very serious threat to societies. Due to these reasons, research to address antibiotic environmental impact 
and the development of remediation strategies has been receiving a lot of attention in the last years.

Two characteristics of the WWTPs make this environment a perfect scenario for the development of antibiotic resistances: i) the final WWTP effluent has $10^{9}-10^{12} \mathrm{CFU}$ (Colony Forming Units) per day and per inhabitant equivalent, and ii) the exposure of the bacterial communities to sub-inhibitory concentrations of antibiotics. Therefore, it is estimated that ca. $1 \%$ of total CFU from the effluent will certainly exhibit antibiotic resistance [32].

Antibiotics are the pharmaceuticals with the highest detection frequency and concentration in receiving waters of the World, being Asia (mostly China and India) the continent with the highest detected antibiotic occurrence and concentration in natural waters, especially tetracyclines and fluoroquinolones [33].

\subsubsection{1. (Fluoro)quinolones}

Fluoroquinolones (FQs) are synthetic broad-spectrum antibiotics extensively used in animal farms, aquaculture facilities and human medicine. From their predecessors, the quinolones (e.g. Nalidixic acid or Oxolonic acid), several synthetic modifications have been made to enhance their therapeutic properties. For instance, the introduction of a fluoride atom in quinolones (only active against Gram-negative) made this antibiotic also active against Gram-positive bacteria (e.g. Flumequine). The other important modification which enhanced the efficiency of FQs as antibiotics was the piperazine moiety (Figure 1.3) (e.g. Ciprofloxacin or Ofloxacin). This ring made them efficient towards an even wider antibacterial spectrum, being defined as FQs second generation [34]. Due to the constant research to improve the features of these antibiotics, nowadays FQs are in the fourth generation, (i.e. Moxifloxacin and Gatifloxacin), making the whole quinolone and FQs antibiotics' family the third-largest group of antibiotics, accounting for $17 \%$ of the global market share [35].<smiles>CC(C)C1C(=O)C(C(=O)O)=CN(C2CC2)C1=O</smiles>

Figure 1.3. Schematic main improvements among fluoroquinolones development.

Their way of action is by inhibiting the DNA-gyrase enzyme, responsible for prokaryotes DNA replication and transcription [36]. As shown in Figure 1.4, they bind the gyrase-induced 
DNA via hydrogen bonds with the unpaired bases and also interact between FQs cores with $\pi$ $\pi$ interaction and hydrophobic bonds through the opposed piperazines rings [37].

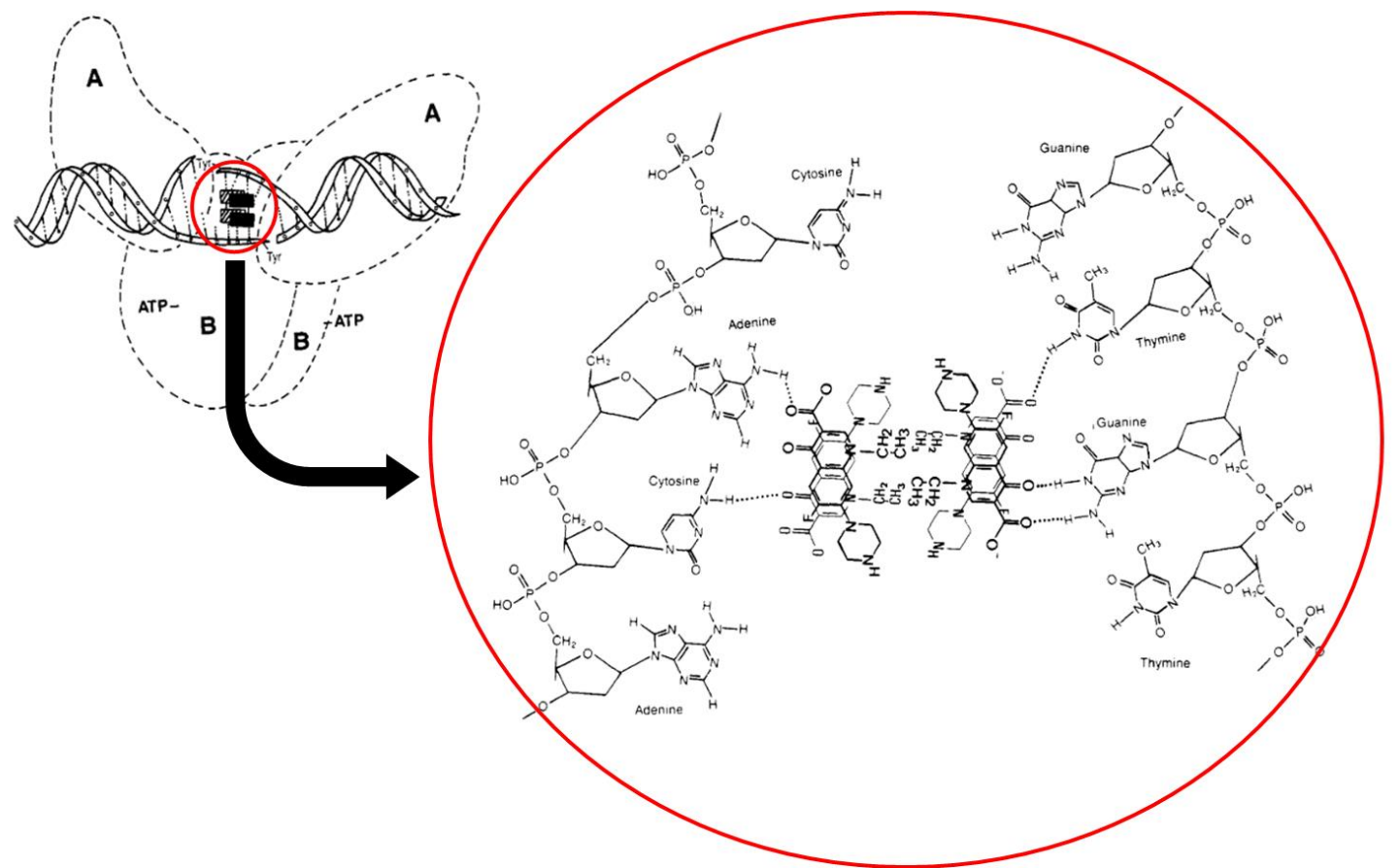

Figure 1.4. FQ interaction model during inhibition of DNA gyrase enzyme. Adapted from figures of Rosen et al., 1989 [37].

Together with cephalosporins and macrolides, quinolones and FQs (together denoted as (F)Qs) are catalogued as "highest priority" within the World Health Organization (WHO) "Critically Important Antimicrobials for Human Medicine" list [38], since they can easily lead to the development of antibiotic-resistant bacteria in animals, eventually reaching the humans as food or through the environment, besides their non-prudent and high consumption all over the globe.

From the chemical point of view, these compounds exhibit zwitterionic behaviour (Figure 1.5), and a very rich variety of plausible interactions with soil [39] and water constituents, like DOM [40], other CECs or metals [41]. In fact, FQs show remarkable complexing properties, for instance, with $\mathrm{Fe}^{3+}$ (Figure 1.6). FQs can act as mono or bidentate ligands, as well as bridging ligand, being the most common coordination mode the one that makes use of carbonyl and carboxyl groups in adjacent positions [42]. To date, however, there is a lack of information about the environmental behaviour of FQ-metal complexes, despite the fact that FQs are very likely to be present complexed with metals rather than as free molecules. FQs as coordination compounds ligands will exhibit different chemical properties than their non-interacting one, changing their mobility between water and soil, become more toxic, or having a higher potentiality to lead the development of resistant bacteria [41]. 

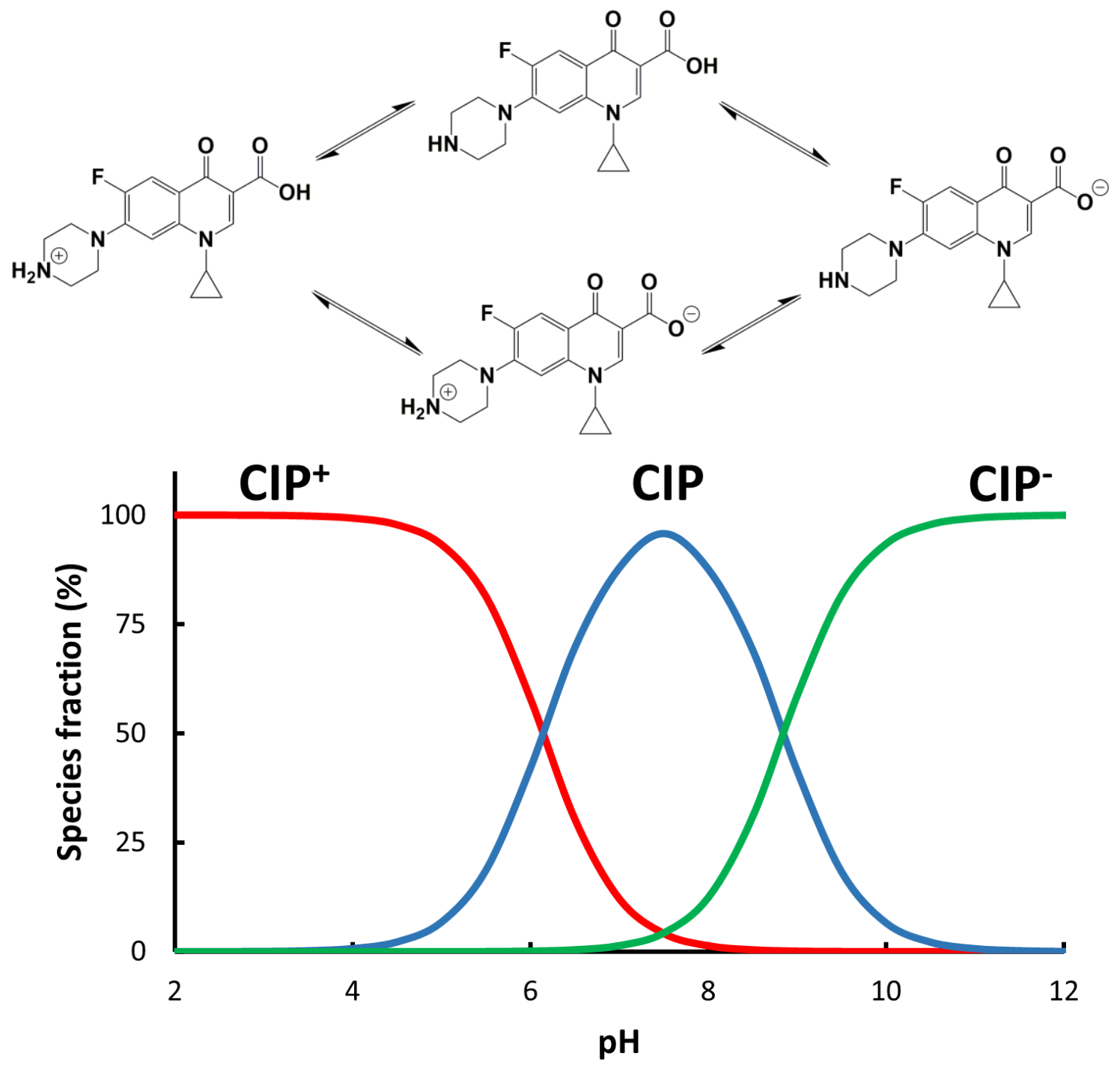

Figure 1.5. CIP hydrochemical speciation as a function of $\mathrm{pH}$.

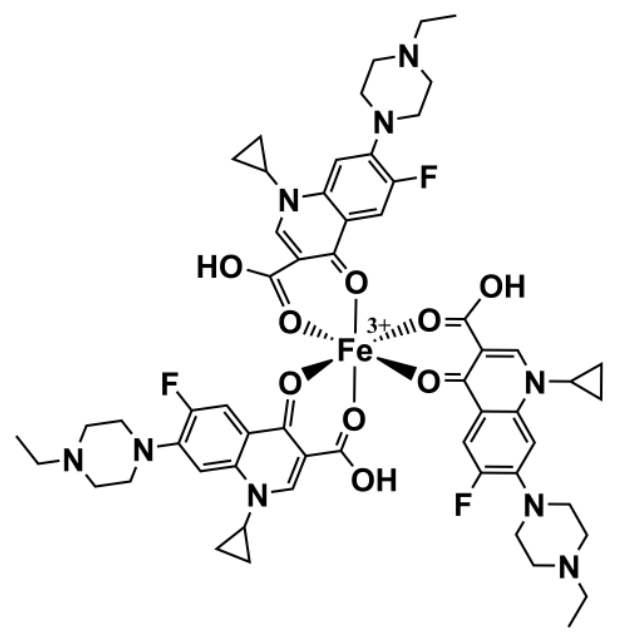

Figure 1.6. $\mathrm{Fe}^{3+}$ coordination complex with Enrofloxacin. 
Moreover, FQs are stable compounds. They are resistant to acid and alkaline hydrolysis, as well as thermal or biological decomposition [43]. Under light irradiation, however, they are easily photolysed, being a significant non-biotic degradation pathway. In this regard, several papers analysing FQs photochemistry had been published already [44,45]. It is demonstrated that even though they are photolabile, they suffer slight molecular changes [46,47]. In fact, they might even transform to another commercial FQ, as is the case of Ciprofloxacin, photolytic intermediate from Enrofloxacin (ENR), generally used for veterinary uses [48]. In fact, due to its complex and wide photochemistry, their phototoxic associated issues within medicine research has been exhaustively studied, being the FQs family one of the drugs that exhibit undesired cutaneous photoreactions as a particular side effect [49]. As would be thoroughly described in the Results and Discussion Chapter, FQs' photochemistry is particularly $\mathrm{pH}$-dependent. The protonation or deprotonation of these molecules produce changes within their electronic structure, which is reflected in modifications of their excited to ground state relaxation mechanisms, for instance, observing an enhancement, or inhibition, of their photolytic rate constants, or changes in their fluorescence intensity and excitationemission maximums wavelengths [44].

Because of their stability, multiple interactions and spread usage, these antibiotics reach the environment in many different ways (briefly summarized in Figure 1.7). Manure disposal in crops as fertilizer and aquaculture activities are major sources of FQs environmental pollution, but also discharge through WWTP effluents and sludge. For the latter, FQs are mainly separated from the effluent through sorption on the sludge in primary and secondary treatments [50]. The pollutant amount remaining in the water fraction has low degradation as they are poorly biodegradable, eventually being discharged on surface water bodies. In fact, FQs behaviour in WWTP is considered a major EU concern according to JRC 2019 report [25], where it is estimated that Ciprofloxacin environmental loadings' reduction will be negligible even after new water directive enforcement, which is mainly attributed to the aforementioned FQs high affinity to sludge, used afterwards as fertilizer.

Therefore, it is not surprising to see that FQs are ubiquitous in surface and groundwater worldwide $[31,43,51,52]$. As a particular example, it must be highlighted the case of India, where extreme concentrations in the range of $\mathrm{mg} / \mathrm{L}$ have been found in WWTP effluents due to their uncontrolled use and discharge near drug manufacturer plants $[53,54]$. In fact, $164 \mu \mathrm{g} / \mathrm{L}$ have been reported as the median global value for Ciprofloxacin, a concentration $2-4$ orders 
of magnitude higher than for most pharmaceuticals, mainly due to the discharges from Asiatic countries [33].

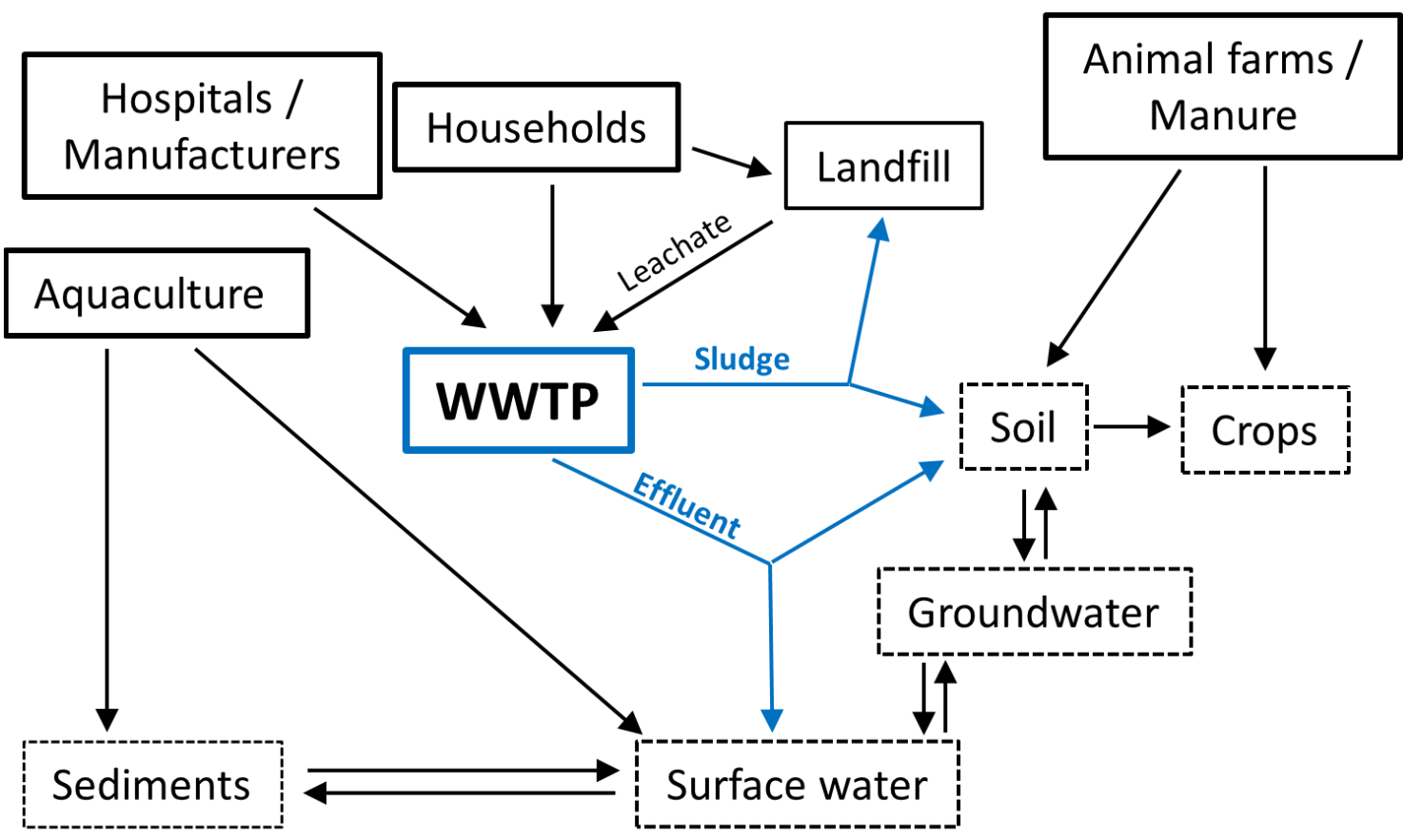

Figure 1.7. FQs different entry routes into the environment.

Along this PhD Thesis, it has been investigated the quinolone, Oxolinic acid (OA), and 5 FQs: Ciprofloxacin (CIP), Enrofloxacin (ENR), Flumequine (FLU), Ofloxacin (OFL) and Sarafloxacin (SAR), all listed in Table 1.1. Only CIP and OFL are used in human medicine, whereas the other ones are intended for veterinary use [43]. In particular, OA and FLU are the most widely employed in aquaculture (fish and shrimps), either added in the feed or applied in bathing dosages [55].

Table 1.1. Molecular structure and reported pKa values $[43,56]$ for investigated (fluoro)quinolones in this PhD Thesis.

\begin{tabular}{|llll|}
\hline (Fluoro)quinolone & Structure & $\mathbf{p K a}_{2}$ \\
\hline Enrofloxacin (ENR) & & \\
\hline
\end{tabular}




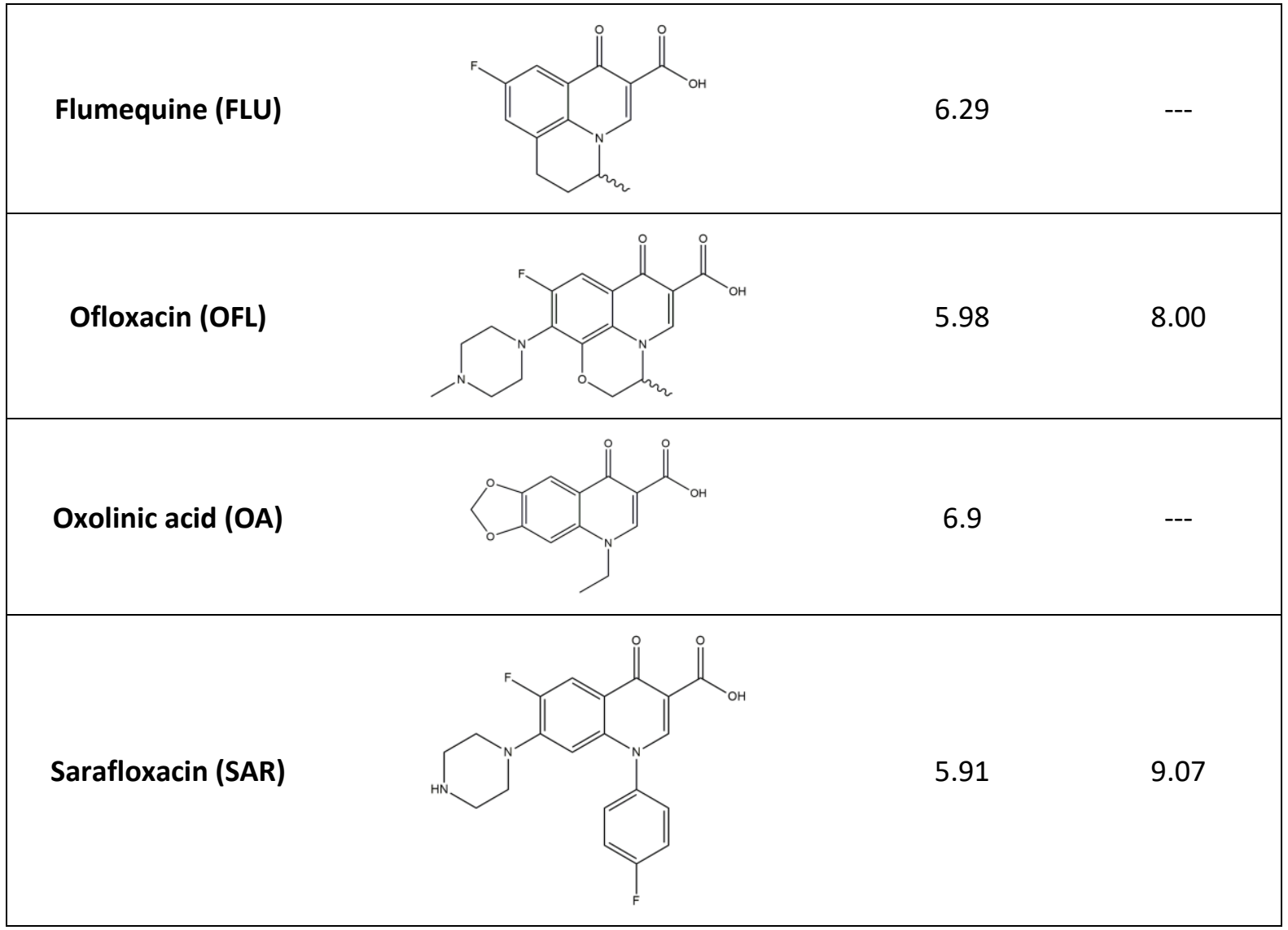

Having explained DOM and CECs, and their associated issues within DWTP and, particularly, WWTP, especial attention must be paid to explore available and innovative technologies for their abatement, mentioning their advantages, but also plausible lacks.

\subsection{Tertiary wastewater treatments}

Although CEC discharge could be decreased with more sensible consumer habits, it is recognized that these substances are commodities of the vital need for human health; hence, their excretion is unlikely to stop in the future. According to the issues discussed in previous sections, a performance improvement in the WWTP is required to achieve satisfactory CECs and microbiological content abatement. In this regard, tertiary treatment arises as a remarkable alternative to enhance the quality of the effluent and ensure safe disposal. Advanced tertiary treatments might be split into three main categories: I) filtration (i.e. micro-filtration and reverse osmosis), II) chemical oxidation (i.e. chlorination and ozonation) and III) advanced oxidation processes (AOPs) (i.e. $\mathrm{O}_{3} / \mathrm{H}_{2} \mathrm{O}_{2}$ and $\mathrm{H}_{2} \mathrm{O}_{2} / \mathrm{UV}$ ), each one exhibiting their drawbacks and advantages.

Current wastewater reuse systems employ microfiltration followed by reverse osmosis or activated carbon to deal with the high amounts of suspended, colloidal and dissolved solids. 
However, this is not a water treatment itself, specifically being a separation of pollutants instead. One must afterwards deal with the generated concentrate stream, which requires further treatment. Besides, filtration processes have high energy consumption, suffer from constant fouling, and not all the pollutants are retained.

For item II, chemical oxidation, although they might be quite effective towards CECs' degradation, they exhibit drawbacks very challenging to overcome. First of all, they are expensive (high reagent and energy demand, as well as complex infrastructure requirements), and they also lead to the formation of genotoxic and carcinogenic compounds, such as haloacetic acids, trihalomethanes or N-nitrosamines (usually known as disinfection byproducts, DBP), due to their reaction with NOM [16].

On the other hand, AOPs (further explained in the next subsection), arise as an environmentally friendly option compared to the classical chemical treatments described above, capable of efficiently dealing with bio-recalcitrant organic pollutants as well as with bacterial content, with fewer issues than the latter. Particularly interesting is the employment of AOPs in industrial wastewater treatment schemes (i.e., paper-mill, textile or olive-mill industries). However, to target full CEC and bacteria abatement, AOPs become also expensive, requiring high initial investments, which is the main obstacle towards their commercial application. To solve this issue, several expense-saving approaches have been developed. So far, promising results have been achieved through: i) the use of AOP as a secondary pretreatment stage, to make CECs more biodegradable for the subsequent activated sludge reactor; ii) combination of filtration and AOP train systems, and iii) replacement of UV irradiation by sunlight $[57,58]$.

\subsubsection{Advanced Oxidation Processes}

The pioneers, W. Glaze, J. Kang and H. Douglas (1987), defined AOPs as "those which involve the generation of hydroxyl radicals in sufficient quantity to affect water purification" [59]. Since then, AOPs have shown an exponentially growing trend within the scientific community (Figure 1.8) and have found niches not only in water treatment but also as key tools for air and soil decontamination schemes.

Indeed, AOP are technologies where the extremely reactive hydroxyl radical $\left(\mathrm{HO}^{\bullet}\right)$, and also others such as sulfate radical $\left(\mathrm{SO}_{4}{ }^{\bullet-}\right)$, are employed to oxidize bio-recalcitrant organic pollutants. The involved processes are thermodynamic and kinetically favoured; these radicals can oxidize, in a short period, practically every organic substance. Shortly after $\mathrm{F}_{2}, \mathrm{HO}^{\bullet}$ is the 
most powerful oxidant, with a standard reduction potential $\left(\mathrm{E}^{0}\right)$ of $2.80 \mathrm{~V}$, and yields kinetic rate constant for most CECs in aqueous solution for $10^{6}-10^{11} \mathrm{M}^{-1} \mathrm{~s}^{-1}$, which are $6-12$ orders of magnitude higher than the ones reached with $\mathrm{O}_{3}[60]$.

Reaction of CEC with $\mathrm{HO}^{\bullet}$ occurs mainly in three different ways: I) hydrogen subtraction from C-H, N-H, or O-H (R 1.1), II) alkene addition (R 1.2), and III) aromatic addition (R 1.3, this one reversible) [61]. It is also well known that $\mathrm{HO}^{\bullet}$ exhibits a slightly electrophilic behaviour, evidenced, for instance, by the lower efficiency of AOPs towards halogenated compounds or nitroaromatics (see section 4.7). Eventually, the formed by-products continue reacting with $\mathrm{HO}^{\bullet}$ until their total mineralization, yielding $\mathrm{CO}_{2}$ and $\mathrm{H}_{2} \mathrm{O}$, together with inorganic anions in the case of halogenated compounds (such as $\mathrm{X}^{-}$, being $\mathrm{X}=\mathrm{F}, \mathrm{Cl}, \mathrm{Br}$ or $\mathrm{I}$ ), nitrogen (leading to $\mathrm{NO}_{3}{ }^{-}$) or sulfur (leading to $\mathrm{SO}_{4}{ }^{2-}$ ) heteroatoms.

$$
\begin{aligned}
& \mathrm{RH}+\mathrm{HO}^{\bullet} \rightarrow \mathrm{R}^{\bullet}+\mathrm{H}_{2} \mathrm{O} \\
& -\mathrm{C}=\mathrm{C}-+\mathrm{HO}^{\bullet} \rightarrow \mathrm{HO}_{-}-\mathrm{C}^{\bullet}
\end{aligned}
$$

The effectiveness of pollution abatement through AOPs is usually enhanced in presence of dissolved oxygen, as radicals produced in reactions $\mathrm{R} 1.1-\mathrm{R} 1.3$ have fast reactions with it $\left(\approx 10^{9} \mathrm{M}^{-1} \mathrm{~s}^{-1}\right)$, and enhance the production of oxyl $\left(\mathrm{RO}^{\bullet}\right)$ and superoxide $\left(\mathrm{O}_{2}{ }^{\bullet-}\right)$ radicals $(\mathrm{R} 1.4$ and $\mathrm{R} 1.5$, respectively). Contrarily to $\mathrm{HO}^{\bullet}$, the formed $\mathrm{O}_{2}{ }^{\bullet-}$ is quite unreactive. However, its disproportionation reaction to produce $\mathrm{H}_{2} \mathrm{O}_{2}$ and $\mathrm{O}_{2}$ (R 1.6), has high reaction rates $\left(\approx 10^{6} \mathrm{M}^{-1}\right.$ $\mathrm{s}^{-1}$ ) [62]. Consequently, $\mathrm{H}_{2} \mathrm{O}_{2}$ is able to generate more $\mathrm{HO}^{\bullet}$ from several pathways depending on the employed AOP.

$$
\begin{array}{lr}
\mathrm{R}^{\bullet}+\mathrm{O}_{2} \rightarrow \mathrm{R}-\mathrm{OO} & \bullet \rightarrow \mathrm{R}-\mathrm{O}^{\bullet} \\
\mathrm{R}^{\bullet}+\mathrm{O}_{2} \rightarrow \rightarrow \mathrm{O}_{2}^{\bullet-}+\mathrm{R} & \mathrm{R} 1.4 \\
2 \mathrm{O}_{2}^{\bullet-}+2 \mathrm{H}^{+} \rightarrow 2 \mathrm{HO}_{2}^{\bullet} \rightarrow \mathrm{H}_{2} \mathrm{O}_{2}+\mathrm{O}_{2} & \mathrm{R} 1.5
\end{array}
$$




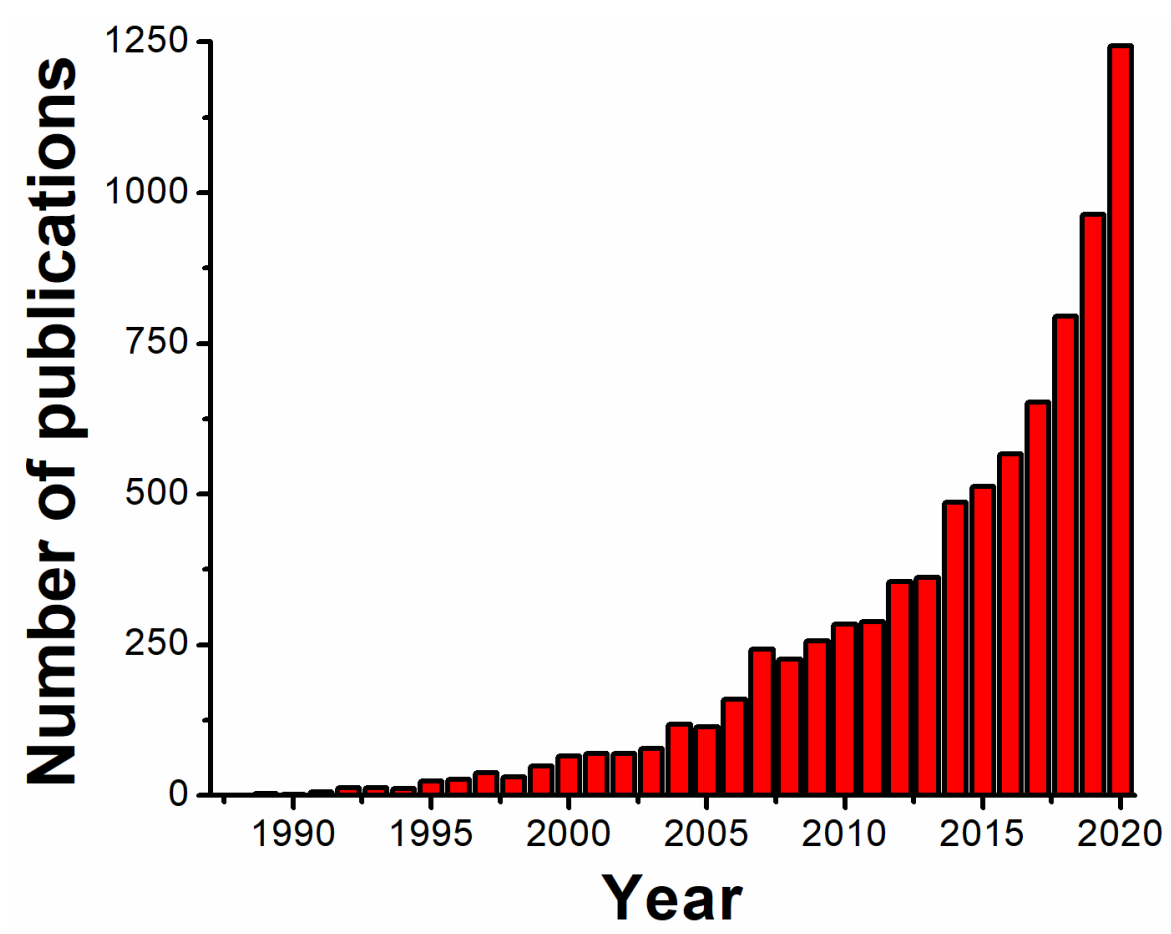

Figure 1.8. Number of publications for AOP related works (source: http://www.scopus.com, February 2021, searched term: "advanced oxidation process").

It is important to stress that production of these reactive radicals will depend not only on the AOP, but also on operational parameters, i.e., emission intensity and energy, reactor design and environment ( $\mathrm{pH}$, turbidity, presence of scavengers, etc.). Therefore, an efficient AOP will be the one with the highest $\mathrm{HO}^{\bullet}$ production favouring their exposure to CECs.

Table 1.2 shows $\mathrm{HO}^{\bullet}$ kinetic rate constants with the most relevant water constituents. These data reflect that for typical effluents, major $\mathrm{HO}^{\bullet}$ scavengers in water are bicarbonates $\left(\mathrm{HCO}_{3}{ }^{-}\right)$, carbonates $\left(\mathrm{CO}_{3}{ }^{2-}\right)$ and nitrites $\left(\mathrm{NO}_{2}{ }^{-}\right)$, the latter usually present in concentrations of $3-4$ orders of magnitude lower than the first ones. Of course, although DOM/NOM were not included in the table, they are also a well-known and relevant $\mathrm{HO}^{\bullet}$ scavengers in natural effluents. On the other hand, bromide $\left(\mathrm{Br}^{-}\right)$shows an alarming parallel reaction whose kinetic rate constant is even higher than that for $\mathrm{HCO}_{3}{ }^{-} / \mathrm{CO}_{3}{ }^{2-}$, with the additional inconvenience of the formed $\mathrm{Br}^{\bullet}$ leading to hypobromite $\left(\mathrm{HBrO}^{-} \mathrm{BrO}^{-}\right)$, which eventually is further oxidized until the formation of bromate $\left(\mathrm{BrO}_{3}{ }^{-}\right)$, a carcinogenic compound [63]. Although $\mathrm{Br}^{-}$is usually in negligible concentrations, for saline waters (such as seawater or hydraulic fracturing wastewater), halogen presence is considerable, and therefore, the formation of halogen-radicals must be bear in mind [64]. 
Table 1.2. Kinetic rate constants of $\mathrm{HO}^{\bullet}$ with typical water constituents at $25^{\circ} \mathrm{C}$ and $\mathrm{pH} 6-8$ [62,65].

\begin{tabular}{|c|c|c|c|}
\hline Ion & $k_{\text {HO० }}\left(M^{-1} s^{-1}\right)$ & $\begin{array}{l}\text { Concentration in } \\
\text { natural water* (mg/L) }\end{array}$ & $\begin{array}{c}\text { Concentration in } \\
\text { secondary effluent* } \\
\text { (mg/L) }\end{array}$ \\
\hline $\mathrm{Cl}^{-}$ & $1 \times 10^{3}$ & 50 & 500 \\
\hline $\mathrm{Br}^{-}$ & $1 \times 10^{9}$ & $<<0.1$ & $<<0.1$ \\
\hline $\mathrm{SO}_{4}{ }^{2-}$ & Not reported & 200 & 500 \\
\hline $\mathrm{NO}_{2}^{-}$ & $1 \times 10^{10}$ & $<0.5$ & 1 \\
\hline $\mathrm{NO}_{3}^{-}$ & Not reported & $<0.5$ & 1 \\
\hline $\mathrm{NH}_{4}{ }^{+}$ & Not reported & $<0.5$ & 5 \\
\hline $\mathrm{HCO}_{3}^{-}$ & $1 \times 10^{7}$ & \multirow{2}{*}{200} & \multirow{2}{*}{1000} \\
\hline $\mathrm{CO}_{3}{ }^{2-}$ & $4 \times 10^{8}$ & & \\
\hline $\mathrm{H}_{2} \mathrm{PO}_{4}^{-}$ & $2 \times 10^{4}$ & \multirow{2}{*}{$<0.5$} & \multirow{2}{*}{10} \\
\hline $\mathrm{HPO}_{4}{ }^{2-}$ & $1 \times 10^{5}$ & & \\
\hline
\end{tabular}

* Approximate values (standard deviation > 50\%).

Up to date, AOPs can be categorized, according to their application scale in: full-scale, pilot plant-scale and laboratory-scale. Complete and thorough developed processes in the fullscale application are: Fenton-(like) $\left(\mathrm{Fe}^{2+} / \mathrm{H}_{2} \mathrm{O}_{2}\right.$ or $\left.\mathrm{Fe}^{3+} / \mathrm{H}_{2} \mathrm{O}_{2}\right)$, photo-Fenton-(like) with UV or solar light irradiation, electrooxidation, ozone combinations, such as $\mathrm{O}_{3}$ at basic $\mathrm{pH}\left(\mathrm{O}_{3} / \mathrm{OH}^{-}\right)$, with hydrogen peroxide $\left(\mathrm{O}_{3} / \mathrm{H}_{2} \mathrm{O}_{2}\right)$ and ultraviolet light $\left(\mathrm{O}_{3} / \mathrm{UV}\right), \mathrm{H}_{2} \mathrm{O}_{2} / \mathrm{UV}$ and $\mathrm{Cl}_{2} / \mathrm{UV}$. Within pilot-plant scale, it can be mentioned heterogeneous photocatalysis (mainly $\mathrm{TiO}_{2} / \mathrm{UV}$ ), plasma and ultrasound. Finally, several AOPs are still being developed at laboratory scale, such as electron beam, microwave based technologies or the use of $\mathrm{TiO}_{2}$ electrodes [65]. Detailed information about these, and many other AOPs, can be found elsewhere [57,66,67]. In this $\mathrm{PhD}$ Thesis, we will focus mainly on Fenton-related processes. Noteworthy, since AOP require some basic concepts of photochemistry, we will first proceed to explain them in the section below.

\subsection{Key-basic concepts of photochemistry}

Electrons have four allowed spin orientations when occupying two different quantum states. One spin configuration $(\alpha, \beta)$ with zero net angular momentum $(S=0)$, out-of-phase, represented by Eq. 1.1, and three other possible configurations, represented by Eq. 1.2, which are in-phase, and the total angular momentum is one $(S=1)$. Due to these reasons, when the configuration is out-of-phase they are called singlet states $\left({ }^{l} X\right)$, whereas the in-phase ones are called triplet states $\left({ }^{3} X\right)$. Because of Hund's multiplicity rule - except for rare exceptions - the energy difference between the singlet and the triplet states is positive $[68,69]$. 


$$
\left.\begin{array}{l}
\frac{1}{\sqrt{2}}\left(\left(\alpha_{1} \beta_{2}\right)-\left(\beta_{1} \alpha_{2}\right)\right) \\
\frac{1}{\sqrt{2}}\left(\left(\alpha_{1} \beta_{2}\right)+\left(\beta_{1} \alpha_{2}\right)\right) \\
\alpha \alpha \\
\beta \beta
\end{array}\right]
$$

The absorption of UV-vis light is powerful enough to produce electronic transitions in some substances. A molecule, $X$, at the ground state goes to an excited one, $X^{*}$, or from an excited state to another one of higher energy. Typically for aromatic compounds, ground state is singlet, and the electronic transition occurs between $\pi$ and $\pi^{*}$ orbitals (bonding and antibonding, respectively). Due to electronic selection rules, the total spin of the molecule cannot change, hence, the excited state will be, in this case, also singlet.

Excited states will decay back to ground state with a first order kinetic, releasing the energy excess as vibrational energy to the solvent (non-radiative processes) and as light (radiative processes), summarized in the so-called Jablonski diagram of Figure 1.9.

Within non-radiative processes, internal conversion and intersystem crossing takes place, both with conservation of energy (horizontal transitions). For the first ones, the transition occurs between a vibrational level from the excited state ${ }^{1} X^{*}$, to a vibrational level from the ground state ${ }^{l} X$ with the same energy than the first one, which is followed by the fastest relaxation transitions from all, the vibrational ones $\left(\mathrm{k}_{\mathrm{vib}} \approx 10^{11} \mathrm{~s}^{-1}\right)$, that takes electron populations to lower vibrational levels (if we are working at room temperature, typically to the lowest vibrational level). In intersystem crossing, the horizontal transition is between ${ }^{l} X^{*}$ and ${ }^{3} X^{*}$. Although the latter is spin-forbidden, for aromatic compounds, it usually has faster kinetic rate constants than internal conversion [68]. On the other hand, the radiative processes (vertical transitions) include fluorescence emission, the relaxation way from ${ }^{l} X^{*}$ to ${ }^{l} X$, and, shortly after intersystem crossing, phosphorescence emission from ${ }^{3} X^{*}$ to ${ }^{1} X$.

An additional radiationless transition is through quenching with another molecule (denoted as Q, from quencher), usually with bimolecular kinetics. 


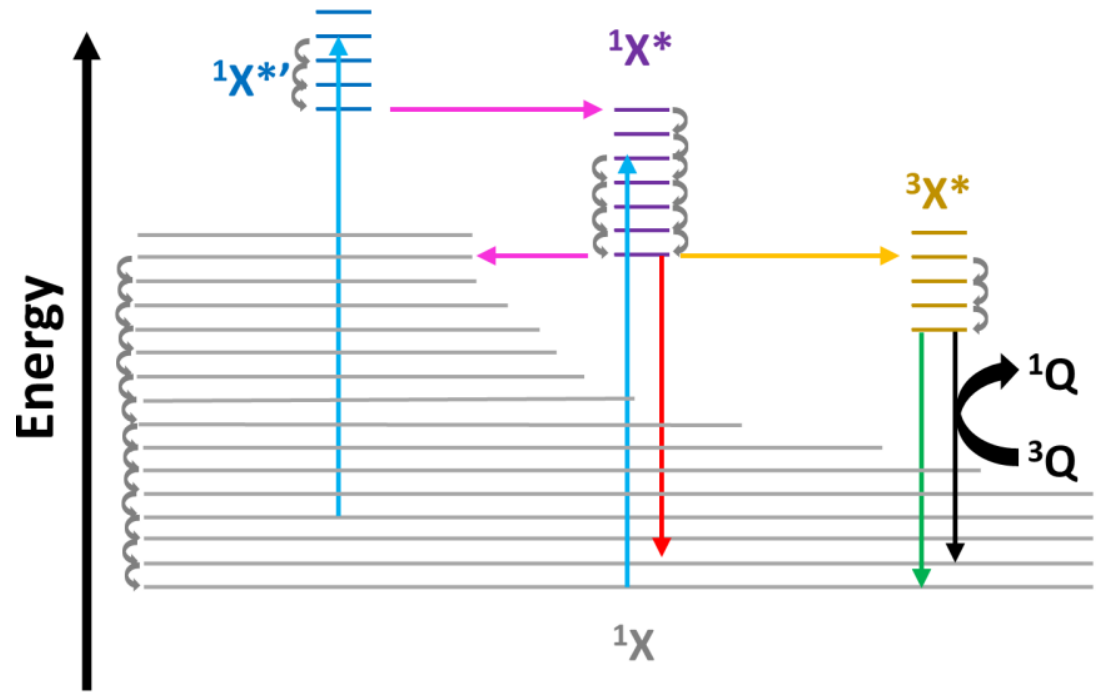

Figure 1.9. Jablonski diagram for a generic molecule with singlet ground state $\left({ }^{1} \mathbf{X}\right)$. Arrow's colors indicate the different photochemical processes: excitation $(\rightarrow)$; internal conversion $(\rightarrow)$; fluorescence $(\rightarrow)$; intersystem crossing $(\rightarrow)$; phosphorescence $(\rightarrow)$; vibrational relaxation $(\rightarrow)$; a type of quenching $(\rightarrow)$.

To measure the overall relevance of a particular photochemical pathway, defining quantum yield is needed. The quantum yield $(\varphi)$ of a particular photochemical process is the relationship between the rate of the considered transition above the total. Besides the temperature, $\varphi$ will also depend on the solvent, i.e., viscosity, polarity and/or $\mathrm{pH}$.

For example, being $\mathrm{k}_{\mathrm{F}}, \mathrm{k}_{\mathrm{ISC}}, \mathrm{k}_{\mathrm{IC}}$ and $\mathrm{k}_{\mathrm{Q}}[\mathrm{Q}]$, the rate constants for fluorescence, intersystem crossing, internal conversion and quenching (multiplied by the quencher's concentration), respectively, the fluorescence quantum yield, $\varphi_{F}$, will therefore be calculated as Eq. 1.3:

$$
\Phi_{F}=\frac{k_{F}}{k_{F}+k_{I S C}+k_{I C}+k_{Q}[Q]}
$$

\subsubsection{Electronic spectroscopy of transition-metal complexes}

As previously mentioned, transition metals, such as Fe, can form complexes with certain anions or organic ligands. These coordination complexes can have four types of electronic transitions: i) d-d, ii) metal to ligand, iii) ligand to metal, and iv) ligand to ligand. The molar absorptivity coefficient $(\varepsilon)$ is probabilistic-dependent, and hence, selection rules dependent. These transitions are summarized in Figure 1.10.

According to selection rules, $\mathrm{d}-\mathrm{d}$ transitions can be spin-forbidden and Laporte allowed $\left(\varepsilon \approx 10^{-3}-1 \mathrm{M}^{-1} \mathrm{~cm}^{-1}\right)$, or the opposite, Laporte forbidden and spin-allowed $\left(\varepsilon \approx 1-10 \mathrm{M}^{-1} \mathrm{~cm}^{-}\right.$

${ }^{1}$ ). The most intense absorption bands, however, are observed for ligand to metal charge transfer 
(LMCT), metal to ligand charge transfer and ligand to ligand charge transfer, which are spin and Laporte allowed transitions $\left(\varepsilon \approx 100-1 \times 10^{6} \mathrm{M}^{-1} \mathrm{~cm}^{-1}\right)[70]$.

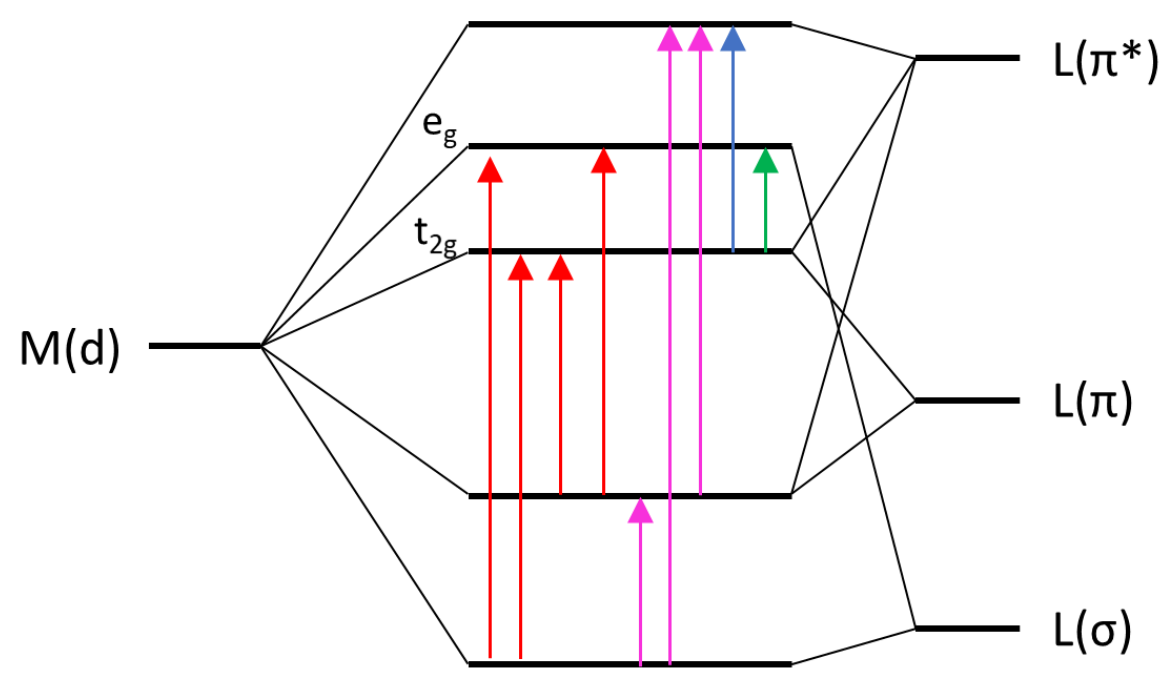

Figure 1.10. Electronic transitions for octahedral coordination complexes: ligand to metal charge transfer $($ LMCT) $(\rightarrow)$, ligand to ligand charge transfer $(\rightarrow)$, metal to ligand charge transfer $(\rightarrow)$ and d-d $(\rightarrow)$.

\subsection{2. $\underline{\text { Photolysis }}$}

There are two main photodegradation pathways, direct and indirect, which are not exclusive one from the other, thus being both possible at the same time. Direct photolysis is only observable for those CECs that are photolabile, or when the irradiation source is very energetic and intense, whereas indirect photodegradation undergoes in the presence of a photosensitizer ("substance that after absorbing light initiates a photochemical/photophysical alteration of another molecular entity without its own consumption", IUPAC definition). Photosensitizing role in urban and natural water is mainly played by NOM and DOM, and/or $\mathrm{NO}_{2}{ }^{-}$and $\mathrm{NO}_{3}{ }^{-}$when present. Some CECs can act as photosensitizers too [71,72].

When talking about direct photolysis, the reaction will be simplified as $\mathrm{R} 1.7$. The mechanisms of this reaction may vary. For example, one possibility is an internal conversion to a lower excited state which exhibit greater energy than the molecule's bond energy [68].

$$
\mathrm{X}^{*} \rightarrow \text { photoproducts }
$$

Another relevant way of direct photolysis occurs when the absorbed photon has greater energy than the molecule's bond energy. As an example, we can mention the AOP of $\mathrm{H}_{2} \mathrm{O}_{2}$ photodissociation with UV ( $\mathrm{R}$ 1.8). For $\mathrm{H}_{2} \mathrm{O}_{2} / \mathrm{UV}$, capital investment in reactor design is minimal, the reagent is stable and $\mathrm{H}_{2} \mathrm{O}_{2}$ has infinite solubility in water. However, one of the major drawbacks of this AOP is the $\mathrm{H}_{2} \mathrm{O}_{2}$ weak molar absorption coefficient, requiring high 
reagent concentrations and powerful lamps (short wavelength, $\lambda<250 \mathrm{~nm}$, with high photon emission rates). This is translated into high electrical consumption and an overall increase in water treatment costs. Besides, an excess of $\mathrm{H}_{2} \mathrm{O}_{2}$ leads to self-quenching reaction ( $\mathrm{R}$ 1.9), which is counterproductive. Noteworthy, at $\mathrm{pH} \geq \mathrm{pKa}\left(\mathrm{H}_{2} \mathrm{O}_{2}\right)=11.6, \mathrm{HO}^{\bullet}$ formation can be enhanced since $\mathrm{HO}_{2}{ }^{-}$has a greater molar absorptivity coefficient $\left(\varepsilon_{254}\left(\mathrm{H}_{2} \mathrm{O}_{2}\right)=18.6 \mathrm{M}^{-1} \mathrm{~cm}^{-1}\right.$ and $\left.\varepsilon_{254}\left(\mathrm{HO}_{2}^{-}\right)=240 \mathrm{M}^{-1} \mathrm{~cm}^{-1}\right)[73]$.

$$
\begin{aligned}
& \mathrm{H}_{2} \mathrm{O}_{2}+\mathrm{h} v \rightarrow 2 \mathrm{HO}^{\bullet} \\
& \mathrm{H}_{2} \mathrm{O}_{2}+\mathrm{HO}^{\bullet} \rightarrow \mathrm{HO}_{2}^{\bullet}+\mathrm{H}_{2} \mathrm{O}
\end{aligned}
$$

Finally, for the indirect photolytic degradation, typically CEC oxidation happens mainly through the reaction with ROS, generated by a photosensitizer, P, whose excited state (R 1.10) is quenched by water and dissolved oxygen ( $\mathrm{R} 1.11-\mathrm{R} 1.13)$, generating singlet oxygen $\left({ }^{1} \mathrm{O}_{2}\right)$, $\mathrm{HO}^{\bullet}$ and $\mathrm{O}_{2}{ }^{\bullet}$. However, photosensitizers such as DOM can also decrease the photodegradation rate of a determined pollutant by producing light screening effect, reacting with the selfphotogenerated ROS, or quenching the pollutant excited states.

$$
\begin{aligned}
& \mathrm{P}+\mathrm{h} v \rightarrow{ }^{1} \mathrm{P}^{*} \rightarrow{ }^{3} \mathrm{P}^{*} \\
& { }^{3} \mathrm{P}^{*}+\mathrm{O}_{2} \rightarrow \mathrm{P}+{ }^{1} \mathrm{O}_{2} \\
& { }^{3} \mathrm{P}^{*}+\mathrm{H}_{2} \mathrm{O} \rightarrow \mathrm{P}^{\bullet-}+\mathrm{H}^{+}+\mathrm{HO}^{\bullet} \\
& { }^{3} \mathrm{P}^{*}+\mathrm{O}_{2} \rightarrow \mathrm{P}^{\bullet+}+\mathrm{O}_{2}^{\bullet-}
\end{aligned}
$$

In the case of $\mathrm{NO}_{2}{ }^{-}$and $\mathrm{NO}_{3}{ }^{-}$, its photochemistry is quite different than the discussed photochemical reactions and, since it has not been studied, will not be discussed in this work. Involved photogenerated radicals, besides $\mathrm{HO}^{\bullet}$, include, $\mathrm{NO}^{\bullet}, \mathrm{NO}_{2}^{\bullet}$ and $\mathrm{ONOO}^{\bullet}$ [74].

\subsection{Processes involving iron for contaminants abatement}

Although iron is the fourth most abundant element in the Earth's crust, in natural waters it can be detected only in negligible amounts. Noteworthy, iron plays several environmentally relevant roles in aqueous systems, as it is critically involved in the regulation of phytoplankton and biomass amount in oceans and in several redox processes [75].

$\mathrm{Fe}^{2+}$ and $\mathrm{Fe}^{3+}$ are iron's most stable oxidation states at environmental conditions, being in surface water mostly present as $\mathrm{Fe}^{3+}$ due to the fast $\mathrm{Fe}^{2+}$ oxidation in presence of dissolved oxygen ( $\mathrm{R}$ 1.14). Moreover, due to their high charge/radius relation, $\mathrm{Fe}^{2+}$ and $\mathrm{Fe}^{3+}$ hydrolyze extremely easily at $\mathrm{pH}>1$ (R 1.15 and R 1.16 ). This hydrolysis capacity and the stability of 
Fe-O bond make iron a very insoluble metal at circumneutral pHs as iron (oxy)hydroxides, (i.e. $\mathrm{Fe}_{2} \mathrm{O}_{3}, \mathrm{Fe}_{3} \mathrm{O}_{4}, \mathrm{FeO}(\mathrm{OH})$ and $\left.\mathrm{Fe}(\mathrm{OH})_{3}\right)$ exhibit negligible water solubility. In Figure 1.11 the change in molar absorption coefficient of the different $\mathrm{Fe}^{3+}$-species and their abundance as a function of $\mathrm{pH}$ is shown.

$$
\begin{aligned}
& 4 \mathrm{Fe}^{2+}+4 \mathrm{H}^{+}+\mathrm{O}_{2} \rightarrow 4 \mathrm{Fe}^{3+}+2 \mathrm{H}_{2} \mathrm{O} \\
& {\left[\mathrm{Fe}\left(\mathrm{H}_{2} \mathrm{O}\right)_{6}\right]^{2+} \rightleftharpoons \mathrm{H}^{+}+\left[\mathrm{Fe}\left(\mathrm{H}_{2} \mathrm{O}\right)_{5}(\mathrm{OH})\right]^{+} \rightleftharpoons \mathrm{H}^{+}+\left[\mathrm{Fe}\left(\mathrm{H}_{2} \mathrm{O}\right)_{4}(\mathrm{OH})_{2}\right]} \\
& {\left[\mathrm{Fe}\left(\mathrm{H}_{2} \mathrm{O}\right)_{6}\right]^{3+} \rightleftharpoons \mathrm{H}^{+}+\left[\mathrm{Fe}\left(\mathrm{H}_{2} \mathrm{O}\right)_{5}(\mathrm{OH})\right]^{2+} \rightleftharpoons \mathrm{H}^{+}+\left[\mathrm{Fe}\left(\mathrm{H}_{2} \mathrm{O}\right)_{4}(\mathrm{OH})_{2}\right]^{+} \rightleftharpoons \ldots \rightleftharpoons} \\
& {\left[\mathrm{Fe}_{2}\left(\mathrm{H}_{2} \mathrm{O}\right)_{4}(\mathrm{OH})_{2}\right]^{4+}+\text { polynuclear species } \rightleftharpoons \ldots \rightleftharpoons \mathrm{Fe}_{2} \mathrm{O}_{3} \downarrow+\mathrm{FeO}(\mathrm{OH}) \downarrow+} \\
& \mathrm{Fe}(\mathrm{OH})_{3} \downarrow+\text { others }
\end{aligned}
$$
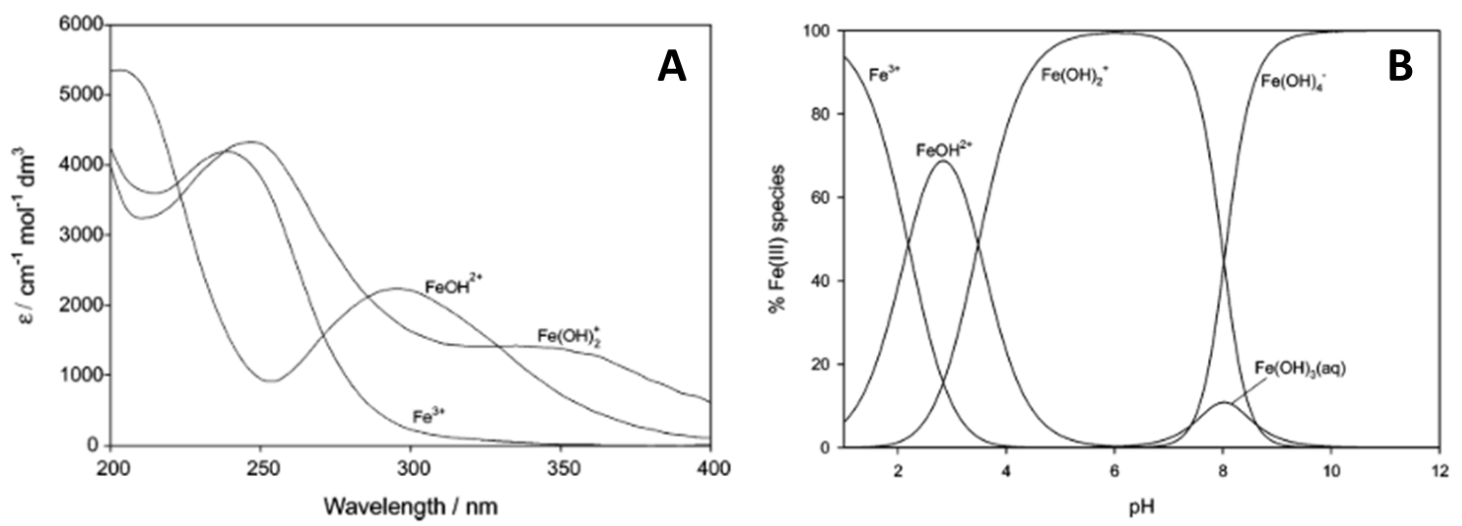

Figure 1.11. $\mathrm{Fe}^{3+}$ hydrolysis: A) molar absorptivity coefficient for the different $\mathrm{Fe}^{3+}$ aquo-complexes; B) speciation plot. Figures were taken from Stefánsson, 2007 [76].

Iron salts (chloride and sulfates) are widely employed also as flocculant agents in both DWTPs and WWTPs. NOM, pathogens and (in)organic pollutants can be easily separated from the water during flocculation (or coagulation) processes. The principles behind coagulation are based on the ability of iron (also of aluminium) to form multi-charged polynuclear complexes due to its hydrolysis, as previously shown in $\mathrm{R} \mathrm{1.16.} \mathrm{Parameters} \mathrm{such} \mathrm{as} \mathrm{mixing} \mathrm{speed,} \mathrm{pH}$ or flocculant dosage will favour hydrolysis species. These polynuclear complexes exhibit great adsorption capability, inducing the precipitation of colloidal or dissolved species, and so clarifying the water [77].

Iron is also one of the key reagents employed in AOPs such as Fenton processes (described below), where it can be used as salts, oxides or directly as metal. For the latter, zerovalent iron (ZVI) has been also demonstrated its capacity to remove heavy metals $[78,79]$.

\subsubsection{Fenton and photo-Fenton principles}


At the end of the XIX century, Henry J. H. Fenton observed that tartaric acid was oxidized in presence of $\mathrm{FeSO}_{4}$ and $\mathrm{H}_{2} \mathrm{O}_{2}$ (1894) [80]. Later on, it was determined that the main chemical species responsible for such a reaction was $\mathrm{HO}^{\bullet}$, formed in the chain mechanism of the homogeneous catalysis reaction ( $\mathrm{R} 1.17$ to $\mathrm{R} 1.23$ ). Such findings converted the $\mathrm{Fe}^{2+} / \mathrm{H}_{2} \mathrm{O}_{2}$ in the oldest AOPs, which is called the Fenton's reagent. When employing $\mathrm{Fe}^{3+} / \mathrm{H}_{2} \mathrm{O}_{2}$ or other transition metals, the reaction is named Fenton-like.

However, up to date the Fenton mechanism is still under revision. For instance, other accepted mechanisms different from the one written below involve the formation of highly oxidized iron species [61,81].

$$
\begin{aligned}
& \mathrm{Fe}^{2+}+\mathrm{H}_{2} \mathrm{O}_{2}+\mathrm{H}^{+} \rightarrow \mathrm{Fe}^{3+}+\mathrm{HO}^{\bullet}+\mathrm{H}_{2} \mathrm{O} \\
& \mathrm{Fe}^{3+}+\mathrm{H}_{2} \mathrm{O}_{2} \rightarrow \mathrm{Fe}^{2+}+\mathrm{HO}_{2}^{\bullet}+\mathrm{H}^{+} \\
& \mathrm{HO}+\mathrm{H}_{2} \mathrm{O}_{2} \rightarrow \mathrm{HO}_{2}^{\bullet}+\mathrm{H}_{2} \mathrm{O} \\
& \mathrm{HO}^{\bullet}+\mathrm{Fe}^{2+} \rightarrow \mathrm{Fe}^{3+}+\mathrm{OH}^{-} \\
& \mathrm{Fe}^{3+}+\mathrm{HO}_{2}^{\bullet} \rightarrow \mathrm{Fe}^{2+}+\mathrm{HO}_{2}^{+} \\
& \mathrm{Fe}^{2+}+\mathrm{HO}_{2}^{\bullet}+\mathrm{H}^{+} \rightarrow \mathrm{Fe}^{3+}+\mathrm{H}_{2} \mathrm{O}_{2} \\
& 2 \mathrm{HO}_{2}^{\bullet} \rightarrow \mathrm{H}_{2} \mathrm{O}_{2}+\mathrm{O}_{2}
\end{aligned}
$$

Since kinetic rate constant $\mathrm{R} 1.17$ is several orders of magnitude faster than the analogous one with $\mathrm{Fe}^{3+}(\mathrm{R} 1.18)$, being $76 \mathrm{M}^{-1} \mathrm{~s}^{-1}$ and $0.02 \mathrm{M}^{-1} \mathrm{~s}^{-1}$ [82], respectively, the latter becomes the rate-limiting step. Therefore, starting from ferrous or ferric salts, will lead to different CEC degradation rates. $\mathrm{Fe}^{2+}$ usually leads to very fast removals in the first minutes due to the rapid $\mathrm{HO}^{\bullet}$ production, observing typical pseudo-first order kinetics. Contrarily, with $\mathrm{Fe}^{3+}, \mathrm{HO}^{\bullet}$ formation will proceed with stationary state $\mathrm{Fe}^{2+}$, hence, degradations are slower within the first minutes, and observing a lag-period before an increment in the degradation rate, recognizing an inflection point between two curves [60].

The advantages of Fenton process are several: i) the reagents are cheap and benign; ii) allows the use of simple reactor designs; iii) as most AOPs, avoids DBP formation. Nevertheless, iron precipitation is the main drawback for this AOP to apply in real scenarios (circumneutral $\mathrm{pH}$ conditions).

Fenton process efficiency (by means of pollutant mineralization and $\mathrm{pH}$ range where the process is still effective) can be enhanced by irradiation (photo-Fenton process). $\mathrm{Fe}^{3+}$-aquo 
complexes significantly absorb within the UV and visible region $(200-400 \mathrm{~nm})$, being $\mathrm{Fe}(\mathrm{OH})^{2+}$ the one with the highest overall molar absorption coefficient within this region (Figure 1.11A). The reason is the generation of $\mathrm{HO}^{\bullet}$ and, most importantly, $\mathrm{Fe}^{2+}$ through LMCT transition of this coordination complex (R 1.24).

$$
\mathrm{Fe}(\mathrm{OH})^{2+}+\mathrm{h} v \rightarrow \mathrm{Fe}^{2+}+\mathrm{HO}^{\bullet}
$$

\subsubsection{Effect of $\mathrm{pH}$ and common anions in iron-based AOPs}

Due to iron chemistry in aqueous system, it could be considered that Fenton processes should be more efficient at $\mathrm{pH} \leq 1$ in order to keep all the iron dissolved. However, the optimal degradations are achieved at $2.5<\mathrm{pH}<3.5$. This is mainly attributed to four reasons: i) there is no $\mathrm{Fe}^{3+}$ precipitation, ii) greater presence of $\mathrm{Fe}(\mathrm{OH})_{2}$ than $\mathrm{Fe}^{2+}$, which is approximately 10 times more reactive for the Fenton reaction than the latter $\left(\mathrm{k}\left(\mathrm{Fe}^{2+}-\mathrm{H}_{2} \mathrm{O}_{2}\right) \approx 60 \mathrm{M}^{-1} \mathrm{~s}^{-1}\right.$ and $\left.\mathrm{k}\left(\mathrm{Fe}(\mathrm{OH})_{2}-\mathrm{H}_{2} \mathrm{O}_{2}\right) \approx 600 \mathrm{M}^{-1} \mathrm{~s}^{-1}\right)$, iii) total $\mathrm{Fe}^{3+}$ speciation form is mainly as $\mathrm{Fe}(\mathrm{OH})^{2+}$, which is the most photoactive one, and iv) the formation of $\mathrm{Fe}^{3+}$ and $\mathrm{H}_{2} \mathrm{O}_{2}$ coordination complexes, $\mathrm{Fe}\left(\mathrm{HO}_{2}\right)^{2+}$ and $\mathrm{Fe}(\mathrm{OH})\left(\mathrm{HO}_{2}\right)^{+}$, which are also $\mathrm{Fe}^{2+}$ sources ( $\mathrm{R} 1.25$ and $\mathrm{R} 1.26$, respectively) and photoactive (R 1.27 and/or R 1.28) $[61,83]$.

$$
\begin{aligned}
& \mathrm{Fe}^{3+}+\mathrm{H}_{2} \mathrm{O}_{2} \rightleftharpoons \mathrm{Fe}\left(\mathrm{HO}_{2}\right)^{2+}+\mathrm{H}^{+} \rightarrow \mathrm{Fe}^{2+}+\mathrm{HO}_{2}^{\bullet}+\mathrm{H}^{+} \\
& \mathrm{Fe}(\mathrm{OH})^{2+}+\mathrm{H}_{2} \mathrm{O}_{2} \rightleftharpoons \mathrm{Fe}(\mathrm{OH})\left(\mathrm{HO}_{2}\right)^{+}+\mathrm{H}^{+} \rightarrow \mathrm{Fe}^{2+}+\mathrm{HO}_{2}^{\bullet}+\mathrm{H}_{2} \mathrm{O} \\
& \mathrm{Fe}\left(\mathrm{HO}_{2}\right)^{2+}+\mathrm{h} \nu \rightarrow \mathrm{Fe}^{2+}+\mathrm{HO}_{2}^{\bullet} \\
& \mathrm{Fe}\left(\mathrm{HO}_{2}\right)^{2+}+\mathrm{h} \nu \rightarrow\left\{\mathrm{Fe}^{3+}-\mathrm{O}^{\bullet} \leftrightarrow \mathrm{Fe}^{+4}=\mathrm{O}\right\}+\mathrm{HO}^{\bullet}
\end{aligned}
$$

Noteworthy, when $\mathrm{pH} \geq 5, \mathrm{Fe}^{3+}$ precipitates, as well as plausible added $\mathrm{Fe}^{2+}$ is rapidly oxidized to $\mathrm{Fe}^{3+}$ with dissolved oxygen ( $\mathrm{R} 1.14$ ), losing the catalyst. Therefore, Fenton reaction is not only hindered but an iron-sludge is also formed, becoming an inconvenient to deal with towards technological applications.

On the other hand, to a higher or minor extent, every anion might cause an inhibitory effect on the photo-Fenton process. For equal concentrations, the inhibitory effect for the most common anions, in decreasing order, is: phosphates $>$ (bi)carbonates $>\mathrm{SO}_{4}{ }^{2-}>\mathrm{Cl}^{-}>\mathrm{NO}_{3}{ }^{-}$. Information in this regard can be found elsewhere $[61,84,85]$. However, for this $\mathrm{PhD}$ Thesis, the effect of chloride is worth to be briefly described. 
Although $\mathrm{Cl}^{-}$is a weak iron ligand and poor $\mathrm{HO}^{\bullet}$ scavenger (Table 1.2), in salty waters (>1 g/L of $\mathrm{NaCl}$ ), both issues become relevant. Reactions $\mathrm{R} 1.29$ to $\mathrm{R} 1.30$ describe the main reactions involved in a photo-Fenton system in these systems [86].

$$
\begin{array}{lr}
\mathrm{Fe}^{2+}+\mathrm{Cl}^{-} \rightleftharpoons \mathrm{FeCl}^{+} & \mathrm{R} 1.29 \\
\mathrm{FeCl}^{+}+\mathrm{H}_{2} \mathrm{O}_{2} \rightarrow \mathrm{Fe}^{3+}+\mathrm{HO}^{\bullet}+\mathrm{OH}+\mathrm{Cl}^{-} & \mathrm{R} 1.30 \\
2 \mathrm{Fe}^{3+}+3 \mathrm{Cl}^{-} \rightleftharpoons \mathrm{FeCl}_{2}^{+}+\mathrm{FeCl}^{2+} & \mathrm{R} 1.31 \\
\mathrm{FeCl}^{2+}+\mathrm{h} v \rightarrow \mathrm{Fe}^{2+}+\mathrm{Cl}^{\bullet} & \mathrm{R} 1.32 \\
\mathrm{Cl}^{\bullet}+\mathrm{Cl}^{-} \rightarrow \mathrm{Cl}_{2}^{\bullet-} & \mathrm{R} 1.33
\end{array}
$$

Regarding $\mathrm{FeCl}^{+}$formation, this does not affect the Fenton kinetic rates ( $\mathrm{R} \mathrm{1.30).} \mathrm{On} \mathrm{the}$ contrary, even though $\mathrm{Fe}^{3+}$-chlorocomplexes are photoactive ( $\mathrm{R} 1.32$ ), they are Fenton-like inactive, avoiding the re-generation of $\mathrm{Fe}^{2+}$ and so decreasing the reaction effectiveness.

On the other hand, despite the fact that $\mathrm{Cl}^{\bullet}$ and $\mathrm{Cl}_{2}{ }^{\bullet-}$ are thermodynamically strong oxidants $\left(\mathrm{E}^{\circ}\left(\mathrm{Cl}^{\bullet} / \mathrm{Cl}^{-}\right)=2.41 \mathrm{~V}\right.$ and $\left.\mathrm{E}^{\circ}\left(\mathrm{Cl}_{2}{ }^{\bullet} / 2 \mathrm{Cl}^{-}\right)=2.09 \mathrm{~V}\right)$ [87], they are less reactive and more selective than $\mathrm{HO}^{\bullet}$, and therefore, they will accumulate, eventually exhibiting a higher concentration than $\mathrm{HO}^{\bullet}$. It should be highlighted that chloride radicals (as well as $\mathrm{Br}^{\bullet}$ when present) can also lead to the formation of halogenated by-products [88,89], a matter of concern due to the potentially carcinogenic and the higher toxicity of this kind of compounds.

\subsubsection{Enhancing the (photo)-Fenton process at circumneutral $\mathrm{pH}$}

Although photo-Fenton can achieve greater mineralization percentages than dark (also known as thermal) Fenton, the treatment is still only efficient at $\mathrm{pH} \approx 3.0$. Solutions to this concern can be grouped in 4 categories: i) acidification; ii) consecutive iron dosages; iii) use of iron chelating agents; iv) use of zerovalent iron (ZVI) or iron oxides [90].

Acidifying could be simple and cheap if the user is dealing with ultra-pure water or demineralized water. However, in the real scenario, with wastewater or natural water, the amount of required acid increases drastically (more than one order of magnitude) due to the buffering effect of $\mathrm{HCO}_{3}{ }^{-} / \mathrm{CO}_{3}{ }^{2-}$. Besides, for the final effluent, operators will have to increase the $\mathrm{pH}$ back to neutral values with alkali dosages previous final discharge in order to accomplish with quality standards normative [91]. However, commonly used acids such as $\mathrm{H}_{2} \mathrm{SO}_{4}$, are not expensive reagents, and through the acidification process until $\mathrm{pH} \approx 3$, 
(bi)carbonates are mostly eliminated as $\mathrm{CO}_{2}$, hence, getting rid of the main $\mathrm{HO}^{\bullet}$ scavenger at the same time (Table 1.2).

Consecutive iron dosages have demonstrated to be more efficient at mild $\mathrm{pH}$ conditions than adding the same quantity all at once. The work of Carra et al., 2014 demonstrated that iron continuously added as an exponentially decreasing function removed acetamiprid (pesticide) at neutral $\mathrm{pH}$ as fast as in the system at $\mathrm{pH} 2.8$ [92]. Moreover, since the iron distribution inside the reactor was better with the mentioned method than administrating it with equally spaced sequenced additions, the way in how iron is being introduced into the reactor is also relevant. In this regard, it must be also taken into account the iron limit emissions according to the subsequent use of the treated water. Fenton process could get rid of all the present CECs, but the result could be also not accomplishing the discharge water directives due to the present levels of iron in the final effluent. For instance, in Andalucía (Spain), according to decree 109/2015, the maximum allowed iron levels emission is $2.2 \mathrm{mg} / \mathrm{L}$ for treated wastewater discharged into surface waters [84].

When using iron-chelating agents, besides extending the Fenton efficiency towards mild $\mathrm{pH}$ conditions, they usually exhibit greater LMCT quantum yields within UV-visible light than aquo complexes, enhancing the formation of $\mathrm{HO}^{\bullet}$ and $\mathrm{Fe}^{2+}(\mathrm{R} 1.34)$. Nevertheless, several drawbacks also arise with the introduction of this new reagent: an overall increment of the treatment's cost, a reduction of the catalytic effect of iron in Fenton and Fenton-like reactions, and $\mathrm{HO}^{\bullet}$ scavenging, thus also requiring higher $\mathrm{H}_{2} \mathrm{O}_{2}$ dosages as well as plausibly generating other reaction by-products (which could be also toxic).

$$
\mathrm{Fe}^{3+}-\mathrm{L}_{\mathrm{n}}+\mathrm{h} v \rightarrow \mathrm{Fe}^{2+}-\mathrm{L}_{\mathrm{n}-1}+\mathrm{L}^{\bullet}
$$

Or

$\mathrm{Fe}^{3+}-\mathrm{L}_{\mathrm{n}}+\mathrm{h} v \rightarrow \mathrm{Fe}^{2+}+(\mathrm{n}-1) \mathrm{L}+\mathrm{L}^{\bullet}$

In Table 1.3, it is shown the molecular structures of some iron chelating agents. Oxalic acid has been one of the first and most successful chelating agents. It is cheap, biodegradable, and its oxidation by-products are not relevant at all. Besides, photogenerated carboxylate radical anion $\left(\mathrm{CO}_{2}^{-\bullet}\right)$ is a strong reducing agent, leading to the formation of $\mathrm{O}_{2}^{-\bullet}$ or reducing $\mathrm{Fe}^{3+}$ into $\mathrm{Fe}^{2+}$ [61]. On the contrary, the well-known chelating agent, ethylenediaminetetraacetic acid (EDTA), applicability has been strongly discouraged due to its recalcitrant nature, poor biodegradability and likelihood of re-dissolution of heavy metals from 
sewage sludge and sediments. In sharp contrast, comparable compounds such as ethylenediamine-N,N'-succinic acid (EDDS) and nitrilotriacetic acid (NTA), represent an environmentally friendly solution to EDTA, and hence, its applicability is now gaining momentum within photo-Fenton process studies at neutral $\mathrm{pH}$ [93]. In all cases, the coordination mode occurs through carboxylic and/or amino moieties.

Finally, some types of DOM have also demonstrated Fe chelation activity. Humic acids are macromolecules that have a high number of coordination sites, hence, when being degraded into smaller fractions, they still have plenty of remaining moieties able to bind iron [90]. This alternative has impulse research towards the isolation of these types of substances from alternative sources such as urban or food industry wastes (i.e. olive oil and wine), enhancing the photo-Fenton process whilst providing value-added to wastes, as explored by A. Amat and A. Arques group in different works [94-96].

Table 1.3. Molecular structures of mentioned chelating agents.

Oxalic acid




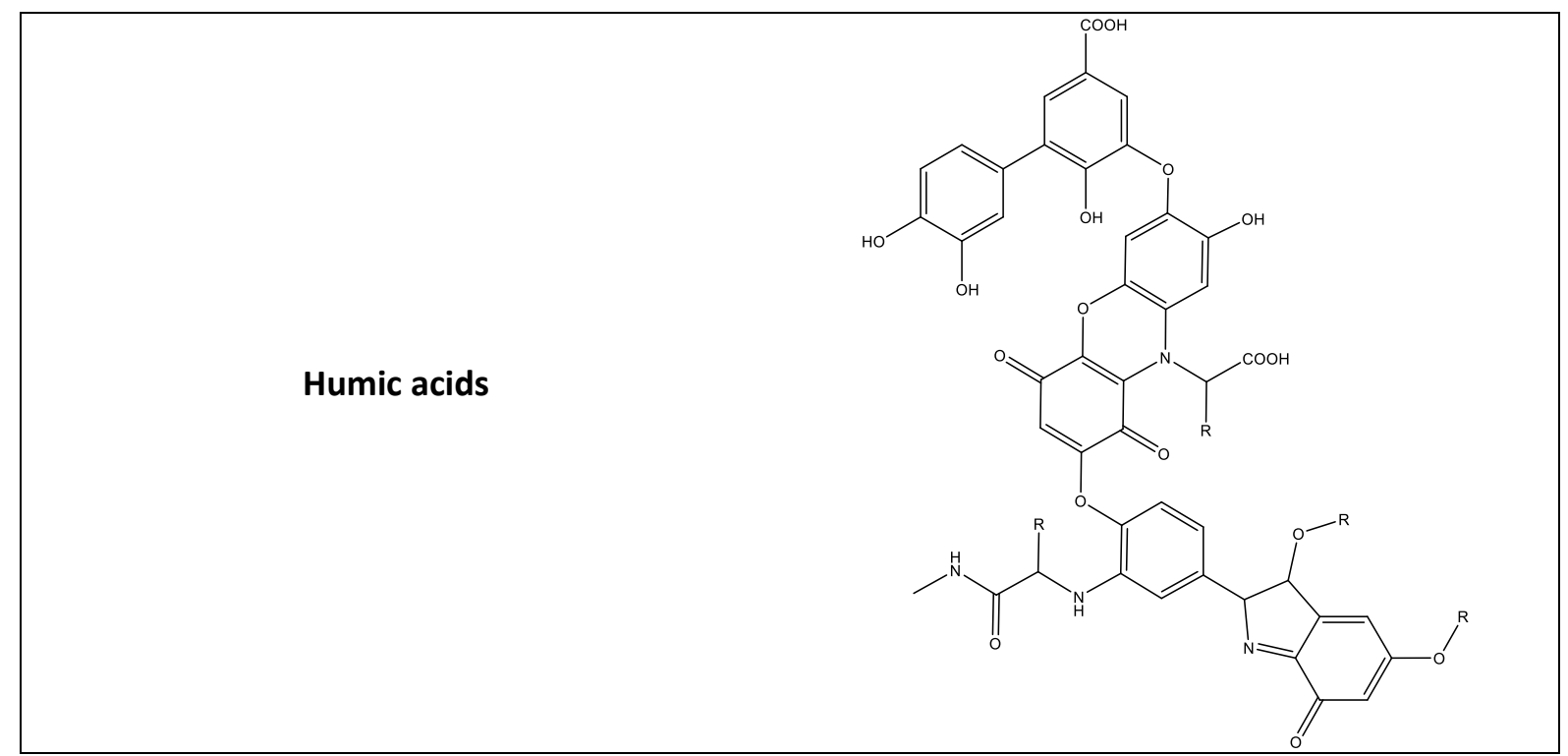

\subsubsection{Zerovalent iron}

Thorough research has been performed to test the capacity of zerovalent iron (ZVI) to remove pollutants from water and wastewater. Its low cost, environmental impact and toxicity, have propelled its study towards a wide array of target pollutants [97]. Several studies have reported promising results for ZVI in the removal of heavy metals, nitrates, azo dyes, and halogenated and nitro organic compounds [79,98,99].

ZVI in water is corroded into $\mathrm{Fe}^{2+}$ (mainly at acidic $\mathrm{pH}$ ), generate $\mathrm{H}_{2} \mathrm{O}_{2}$ in presence of dissolved oxygen, or comproportionate with $\mathrm{Fe}^{3+}$ into $\mathrm{Fe}^{2+}$ ( $\mathrm{R} 1.35-\mathrm{R} 1.38$, respectively) [100].

$$
\begin{aligned}
& \mathrm{Fe}^{0}+2 \mathrm{H}^{+} \rightarrow \mathrm{H}_{2} \uparrow+\mathrm{Fe}^{2+} \text { or } \mathrm{Fe}^{0}+2 \mathrm{H}_{2} \mathrm{O} \rightarrow \mathrm{Fe}^{2+}+\mathrm{H}_{2} \uparrow+2 \mathrm{OH}^{-} \\
& 2 \mathrm{Fe}^{0}+2 \mathrm{H}_{2} \mathrm{O}+\mathrm{O}_{2} \rightarrow 2 \mathrm{Fe}^{2+}+4 \mathrm{OH}^{-} \\
& \mathrm{Fe}^{0}+2 \mathrm{H}^{+}+\mathrm{O}_{2} \rightarrow \mathrm{Fe}^{2+}+\mathrm{H}_{2} \mathrm{O}_{2} \\
& \mathrm{Fe}^{0}+2 \mathrm{Fe}^{3+} \rightarrow 3 \mathrm{Fe}^{2+}
\end{aligned}
$$

The removal of the above mentioned pollutants takes place mainly through reduction by $\mathrm{Fe}^{0}, \mathrm{Fe}^{2+}$ or $\mathrm{H}_{2}$, or oxidation by generated $\mathrm{HO}^{\bullet}$ and $\mathrm{O}_{2}{ }^{\bullet-}[100]$. Moreover, some intermediates can undergo adsorption or co-precipitation on the generated iron (oxy)hydroxides, being afterwards separated from the water body, as it is the case, for example, of $\mathrm{Cr}$ (III) during $\mathrm{Cr}(\mathrm{VI})$ removal [101]. Therefore, ZVI should be always in contact with the pollutant in order to favour the electron exchange. In addition, ZVI is, in natural conditions, covered by a passivation film of its oxides. Although they prevent the bulk to oxidize, these layers also inhibit the mass 
transfer between $\mathrm{Fe}^{0}$-core and the pollutants. Therefore, promoting ZVI corrosion is detrimental for pollutants removal, becoming the main limitation of ZVI technology [78].

Due to the these statements, ZVI technology has proven to be truly successful towards pollutants removal only at acidic conditions. Its applicability at circumneutral conditions has been only enhanced with pre-treatments or synthesis modifications (e.g. bimetals). Examples of simple pre-treatments to activate the ZVI are based on acid-washing or the use of ultrasounds. Both activation techniques have clearly enhanced the effectiveness of the process at neutral $\mathrm{pH}$ [100]. However, even though this can partially solve the issue of ZVI inactivity, it does also notably increase the operational costs.

Since ZVI chemistry involves many complex reactions, there is still a discrepancy within the reported works of the effect of water constituents. For instance, it was reported that As(V) reduction rates decrease in presence of different anions, being this inhibition effect more important when having $\mathrm{HCO}_{3}^{-}$[102]. Similarly, trichloroethylene dehalogenation by ZVI nanoparticles was significantly reduced when anions were present [103]. On the other hand, Yin and co-workers observed that $\mathrm{Cl}^{-}$continuously favoured nitrobenzene reduction when gradually increasing its concentration from 0 to $1 \mathrm{~g} / \mathrm{L}$, whereas this only happened in a certain concentration range for $\mathrm{SO}_{4}{ }^{2-}$ and $\mathrm{HCO}_{3}{ }^{-}$.

\subsubsection{ZVI-based Fenton}

Most recently, increasing interest towards the use of ZVI replacing iron salts within the Fenton process has arisen due to its effectiveness for pollutant degradation in mild $\mathrm{pH}$ conditions and, therefore, its larger versatility. Such an approach exhibits the additional advantage of the ease of separation of the excess of ZVI after pollutant abatement [81]. ZVIFenton based treatments exhibit both, homogeneous and heterogeneous Fenton, the first one contributing more to the pollutant abatement, and the second one via the generated oxides with adsorbed $\mathrm{Fe}^{2+} / \mathrm{Fe}^{3+}$ species. Moreover, it can also activate some CEC, for instance, through dehalogenation, getting rid of electron withdrawing groups [104].

However, despite the results proposing that ZVI-based Fenton can be more effective at circumneutral $\mathrm{pH}$ conditions than the purely homogeneous one, due to the aforementioned ironoxide external layer, most works only show that ZVI technology is still only effective at acidic conditions or require a pre-treatment in order to be reactive at neutral conditions $[100,105,106]$. In addition, differently from the iron salts, ZVI consumes $\mathrm{H}_{2} \mathrm{O}_{2}$ (R 1.39), requiring higher concentrations of it than homogeneous Fenton. 


$$
\mathrm{Fe}^{0}+\mathrm{H}_{2} \mathrm{O}_{2} \rightarrow \mathrm{Fe}^{2+}+2 \mathrm{OH}^{-}
$$

Another alternative to the simultaneous use of $\mathrm{ZVI}$ with $\mathrm{H}_{2} \mathrm{O}_{2}$ is proceeding by splitting them into two individual steps, the first one with ZVI alone, followed by a Fenton process in a second step [107]. The main advantages of this arrangement could be: parent pollutant reactivity increment, lower $\mathrm{H}_{2} \mathrm{O}_{2}$ consumption and possible application of Fenton reaction in continuous mode, which can certainly facilitate the scaling up of the process [108]. In this regard, few works investigating this approach have been published. According to the bibliography, the first work employing coupling ZVI pre-treatment/Fenton process was performed by S. Oh et al. 2003, for the elimination of 2,4,6-trinitrotoluene and hexahydro1,3,5-trinitro-1,3,5-triazine within ammunition industry wastewater treatment [109]. Similarly, nitrobenzene removal with sequential ZVI-reduction/Fenton oxidation treatment has proven to significantly avoid the formation of the 30 times more toxic by-product, 1,3-dinitrobenzene, which was normally generated in the classical Fenton process [110]. In these two examples, after ZVI pre-treatment, the electron-withdrawing nitro group $\left(-\mathrm{NO}_{2}\right)$, was changed into the electron-donor one, amino $\left(-\mathrm{NH}_{2}\right)$, hence, increasing the kinetic rate constant of the original pollutant against $\mathrm{HO}^{\bullet}$, which for nitrobenzene represents about $3-4$ folds enhancement [62]. Interesting results can also be found for textile industry wastewater, pre-reducing the azo group $(-\mathrm{N}=\mathrm{N}-)$ to $-\mathrm{NH}_{2}$, thus producing the molecule cleavage, decolorizing the wastewater, as well as increasing the reactivity of the generated by-products shortly before the Fenton oxidation [111].

\subsection{EEM-PARAFAC}

\subsubsection{Fluorescence}

Due to fast internal conversion transitions between singlet excited states (Figure 1.9), fluorescence transition usually occurs between the fundamental vibrational level of the first excited state to a certain vibrational level from the ground state. As a consequence, fluorescence emission spectra exhibit a single maximum (in contrast with absorbance spectrums that might have more than one) and it appears at higher wavelengths than the excitation spectra (Stokes shift). Stokes shift has another relevant component, which is the role of the solvent. After an electronic transition, there is a dipole moment rearrangement from the fluorophore's molecules. As a result, shortly after this, a dipole moment rearrangement of the solvent molecules occurs. Therefore, the energy gap between excited and ground state is reduced, producing red-shifts (higher wavelengths) (Figure 1.12A). 
As well as with the excitation transition, the emission maximum wavelength will correspond to the energy difference between the two vibrational levels where the greatest wavefunction overlapping occurs (Figure 1.12B), hence, where the transition is most probable. Due to this reason, the emission spectrum is usually called in textbooks the "mirror image" of the excitation spectrum, besides from also being highly temperature-dependent (Boltzmann distribution) [68],
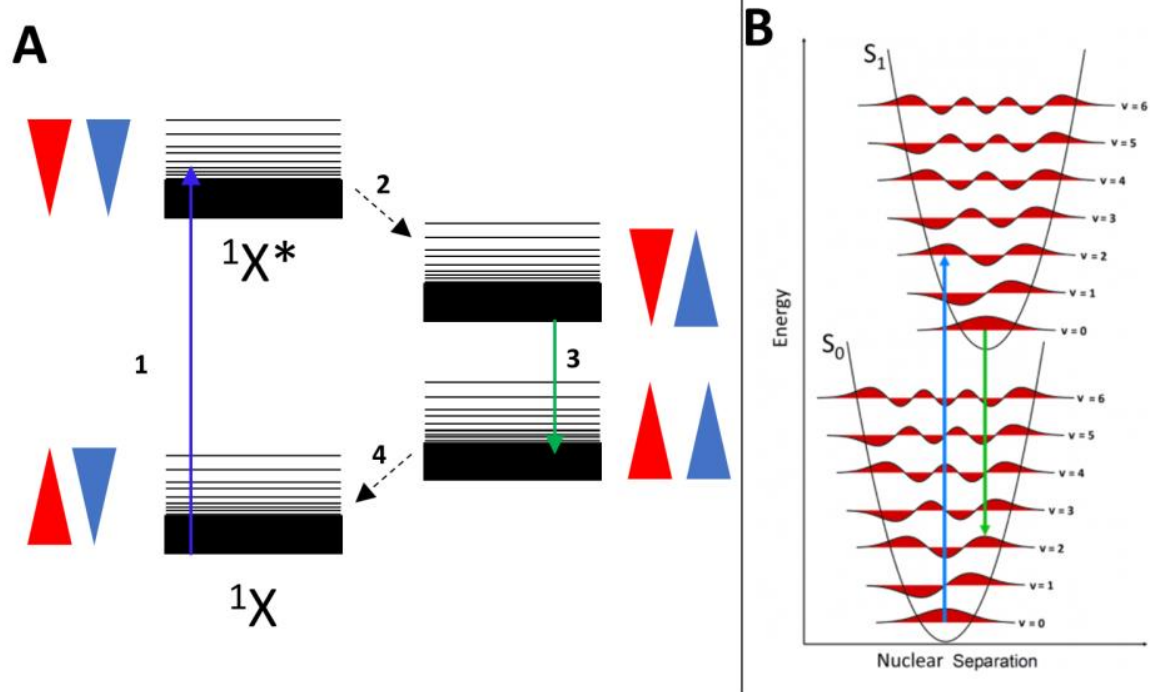

Figure 1.12. A) Stokes shift. Red and blue triangles symbolize the fluorophore and solvent dipole moments, respectively; B) Frank-Condon principle for an excitation (blue) and fluorescence (green) transitions between ground and excited states ( $S_{0}$ and $S_{1}$, respectively) [112].

Regarding the main interferences we can mention [113]:

- Light scattering: there are two types, Rayleigh and Raman, both with two observable orders and solvent-dependent. The first one is elastic and, therefore, with the same energy as the incident light, observing them when $\lambda_{\mathrm{ex}}=\lambda_{\mathrm{em}}$. On the contrary, Raman scattering is inelastic and their signals appear when $\lambda_{\mathrm{ex}}<\lambda_{\mathrm{em}}$. Rayleigh scattering is the most intense.

- Inner filter effect: the incident light is unavoidably absorbed by the analyte and/or other compounds. If the absorbance is high (>0.1), the incident light is mainly quenched within the first millimetres of the optical path, hence, reaching fewer photons to the cell centre.

- Self-quenching: concentrated samples will favour non-radiative relaxation transitions, diminishing fluorescence quantum yields. 
- Self-absorption: the emission spectra from one analyte overlaps with the excitation spectra of another one, diminishing the fluorescence intensity signal of the first.

- Interaction with other compounds: chemical interactions, such as strong intermolecular forces or metal chelation, can also affect the molecule's planarity and/or electronic delocalization, hence, modifying the fluorescence quantum yield or even excitation-emission maximum wavelengths.

\subsubsection{Fluorescence excitation-emission matrix (EEM)}

In Figure 1.13A, the excitation and emission spectra for ENR is shown. This example shows every aspect that has been mentioned above: the excitation spectrum and emission spectrum, do not overlap; excitation spectrum has more than one maximum (ca. 270, 310 and $330 \mathrm{~nm})$, whereas for the emission there is only one (445 nm); Rayleigh scattering at $550 \mathrm{~nm}$ and Raman scattering at ca. $300 \mathrm{~nm}$ (seen only in the emission spectrum).

When collecting the different excitation and emission spectrums together, a threedimensional plot called fluorescence Excitation-Emission Matrix (EEM) is obtained (Figure 1.13B). This kind of plots is usually analysed as two-dimensional topographic surface (see later section 1.7.2.2), as it is shown in Figure 1.13C. 


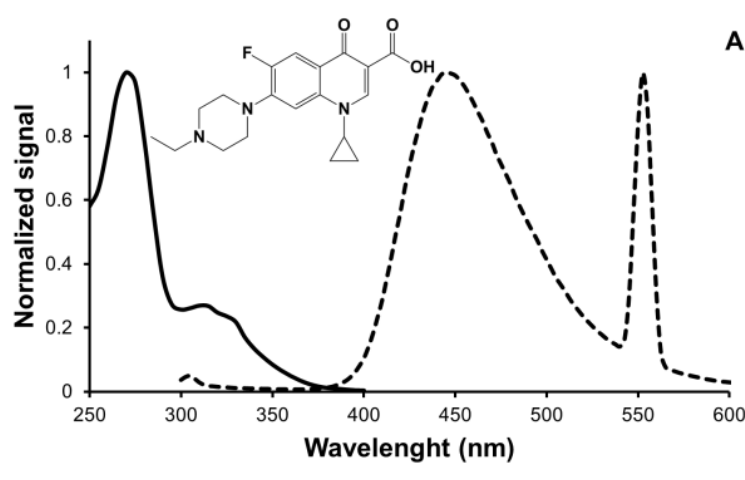

A
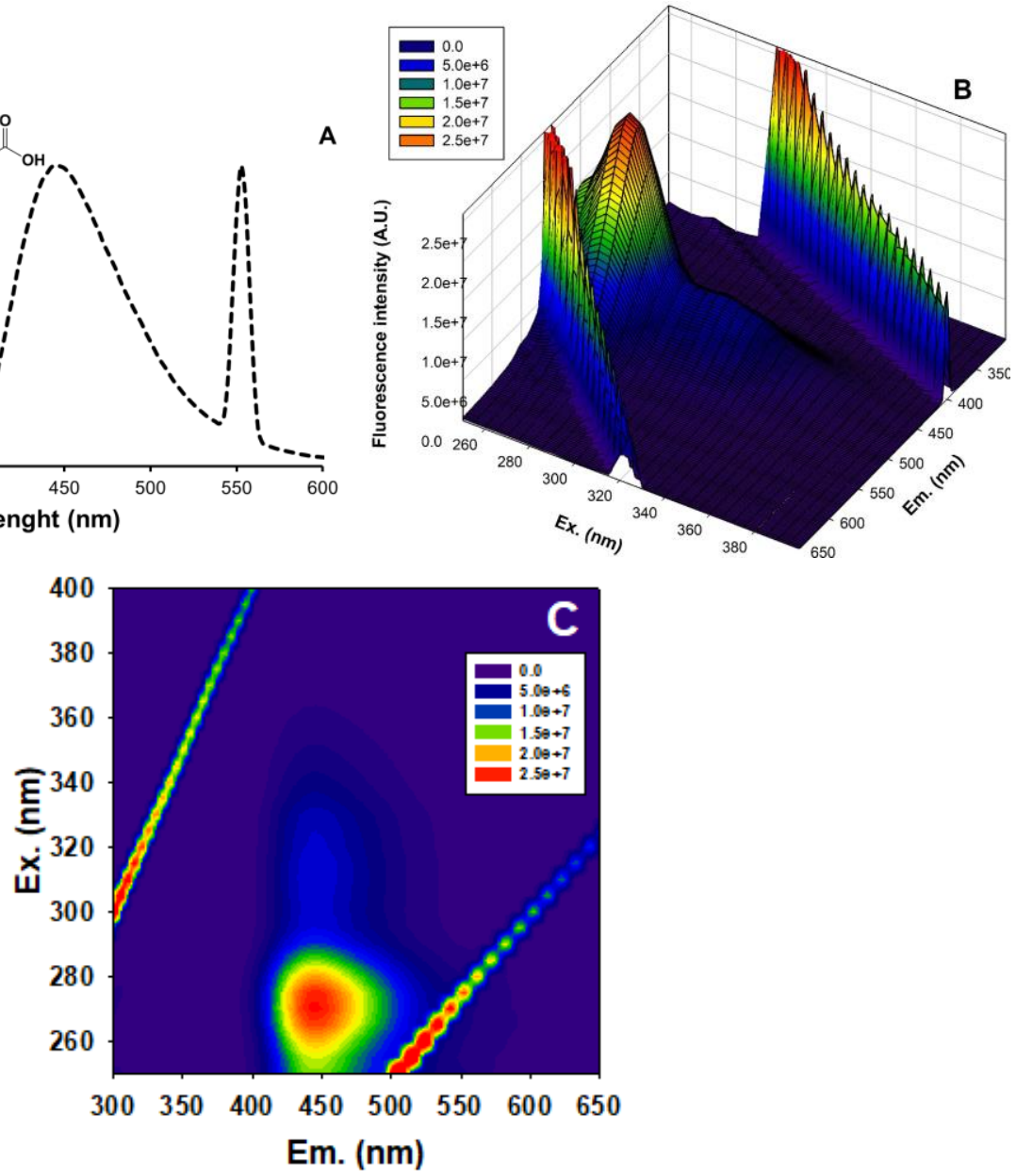

Figure 1.13. ENR $1.4 \mu \mathrm{M}$ fluorescence at $\mathrm{pH} 4.0$ in ultra-pure water: $\mathrm{A})$ normalized excitation $\left(\lambda_{\mathrm{em}}=445\right.$ $\mathrm{nm}$, full line) and emission ( $\lambda_{\mathrm{ex}}=270 \mathrm{~nm}$, dotted line) spectrums; B) EEM; C) bidimensional EEM.

\subsubsection{Multivariate analysis}

Complex sample analysis containing several chemical compounds constitutes one of the most important challenges in analytical chemistry. The difficulty scales up when the user tries to measure, in a cost-efficient way and simultaneously, all the analytes from a sample in low concentration and in presence of interferences.

The signal of a single compound at a given wavelength in ultra-pure water, this is in absence of unknown contribution or interferences to background noise, could be the best example for a univariate measurement. In these cases, the analytical information is extracted through an univariate regression. The instrument signal is, generally, selective and proportional to the analyte concentration. However, when this is not the case and/or more than one analyte or interferences are present, separation should be performed, which could be physical (e.g. chromatography) or chemical (e.g. chelating agents to mask the interference). In any case, single calibration curves for each one of the target analytes are required [114]. 
As an alternative, simultaneous analyte determination without separation method can be performed in some cases through chemometric tools, which use different types of multivariate analysis. Multivariate analysis exhibits the ability to extract information in presence of unknown interference signals, as well as allowing simultaneous measurement of more than one analyte without a previous separation method [115]. To do so, each multivariate analysis seeks the same objective, the reduction of the number of initial variables (dimensionality reduction).

Chemometrics tools can be coupled to many different analytical methods, being extremely useful in the analysis of complex information data sets. In this work, only two will be described, the principal component analysis (PCA) and, most importantly, the parallel factor analysis (PARAFAC)

\subsubsection{Principal Component Analysis (PCA)}

Briefly, the idea behind PCA is to generate new variables, $C_{1}, C_{2}, \ldots, C_{N}$, being linear combinations from the original variables (Eq. 1.4). Such a process allows achieving dimensionality reduction and therefore simplifies the data set analysis.

Each of the linear combination coefficients, $c_{i l}, \ldots, c_{i N}$, are called "loadings" and the projected data on $C_{l}, \ldots, C_{N}$, "scores". The linear combinations are made in a way where $C_{l}$ will be in the direction where the variance of the projected data is maximized, followed by $C_{2}$ (orthogonal to $C_{1}$ ), and so on. Therefore, there will be a certain number of the newly constructed variables which will accumulate the relevant information of the system in decreasing order, being the last linear combinations only describing the noise or interferences. The variables describing the system are called Principal Components. Mathematically, the Principal Components are the eigenvectors from the covariance matrix. To each eigenvector, the belonging eigenvalue provides the data-set variance amount from that particular principal component [116].

$$
C_{i}=c_{\mathrm{i} 1} X_{1}+c_{\mathrm{i} 2} X_{2}+\cdots+c_{i N} X_{N}
$$

To better understand PCA, an example of two generic variables, $X_{1}$ and $X_{2}$ is shown in Figure 1.15, indicating how the principal components, $C_{1}$ and $C_{2}$, could be constructed and placed. 


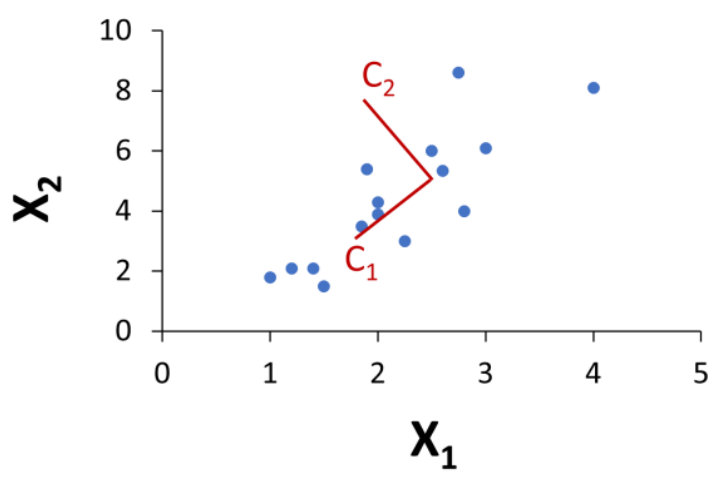

Figure 1.14. 2-way PCA scheme for a generic system initially analysed by variables $X_{1}$ and $X_{2}$. Principal components, $C_{1}$ and $C_{2}$, are shown in red lines.

\subsubsection{Parallel factor analysis (PARAFAC)}

Although it has had its origins within psychometrics, its uses have spread from fake news to geospatial analysis, being nowadays its principal applicability the component deconvolution from EEM datasets [117].

Parallel factor analysis (PARAFAC) is a $N$-way method, being $N$ the system's dimensionality. Differently from PCA, PARAFAC remains with its multivariate structure. For EEM analysis, data will be decomposed with three trilinear elements, $a_{i f}, b_{j f}$ and $c_{k f}$ as stated by Eq. 1.5. Therefore, the aforementioned scores will be related with the fluorescence intensity from each fluorophore present in the EEM dataset.

$$
x_{i j k}=\sum_{f=1}^{F} a_{i f} b_{j f} c_{k f}+e_{i j k}
$$

In Eq. 1.5, there will be a given number of $I$ total samples whose fluorescence was determined in a certain range of $J$ excitation and $K$ emission wavelengths. $x_{i j k}$ will be the data point corresponding to the $i^{\text {th }}$ sample, $j^{\text {th }}$ excitation and $k^{\text {th }}$ emission wavelengths, respectively, and with a variability not considered by the model, $e_{i j k}$. Therefore, if it is considered that dataset contains a number $F$ of fluorophores (called factors or components), $a_{i f}$ will be directly proportional to the concentration of the $f^{\text {th }}$ component in the $i^{\text {th }}$ sample, $b_{j f}$ an estimate of its emission spectrum, and $c_{k f}$ the estimate of its excitation spectrum, being $f=1, \ldots, F$ [117].

The major advantage of PARAFAC is its solution uniqueness, which is obtained through the Alternating Least Squares algorithm. According to the chosen number of components, this algorithm will give certain initial loadings to two of the three trilinear elements, calculating with least-squares the loadings for the remaining element. Therefore, the model is improved with each iteration until it is reached convergence in a global minimum [115]. 
On the other hand, the right number of factors to model the dataset can be chosen according to different possible criteria (main drawback of the method), being always mandatory to have chemical consistency (example in Figure 1.15). The two most accepted algorithms that can usually help choosing the correct number of factors are the split-half analysis method and core consistency diagnostic (CORCONDIA).
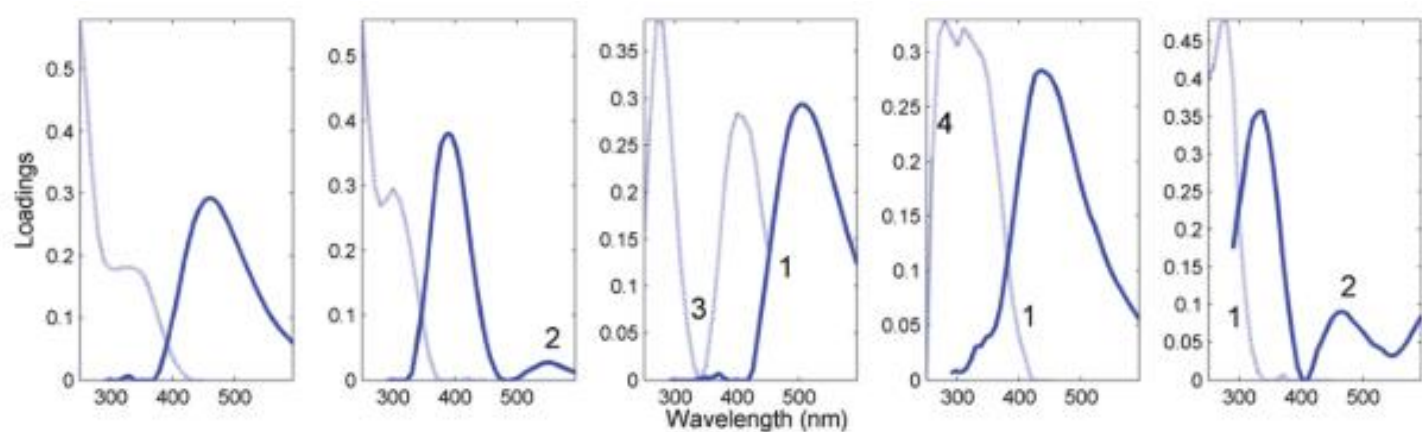

Figure 1.15. PARAFAC components model without chemical consistency. Inserted numbers indicate the following inconsistencies: (1) excitation and emission spectrums significant overlapping; (2) multiple distinct emission peaks, (3) excitation extinguish; (4) abrupt spectral changes over short wavelength distances. The light and dark curves represent excitation and emission spectra, respectively [117].

In Figure 1.16 a schematic example of PARAFAC applied to study the degradation of a mixture of different pollutants is shown. The best model explaining this dataset (taken from section 4.5) is one of 7 components, each of them belonging to a certain fluorophore present at least in one of the samples from the dataset, uploaded individually (case of parent pollutants which can be calibrated) or already contained in the mixture (interferences such as generated oxidation by-products or DOM from the water matrix). Afterwards, the scores (proportional to the fluorescence intensity) from each of the 7 components can be obtained for each sample, in this particular example, different time intervals. 


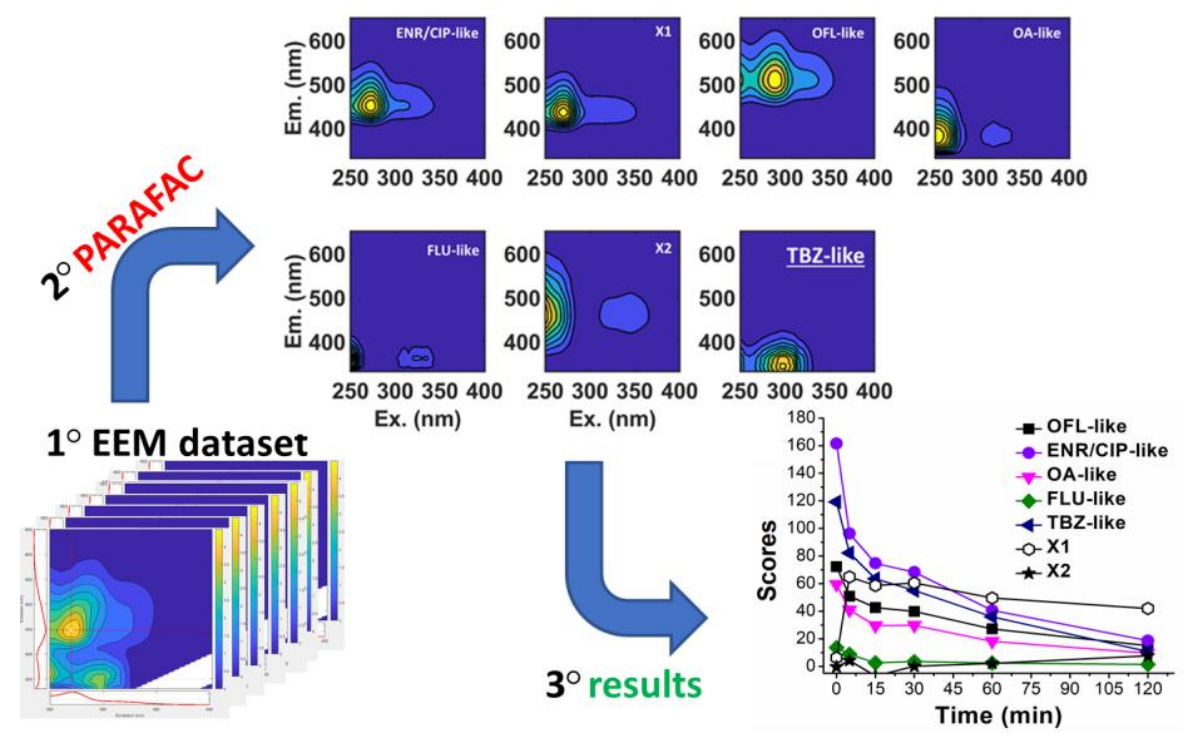

Figure 1.16. PARAFAC used for fluorescent signal deconvolution for an EEM dataset. A model of 7 components and their scores from each of the dataset's samples (time intervals) is the final result.

It is important to bear in mind that, since fluorescence intensity is dependent on its quantum yield, when comparing scores from different compounds, if one has higher score values than the other component, it does not necessarily mean that it is present in a higher concentration. Moreover, in case one or more compounds exhibit highly similar EEM to be deconvoluted, the scores of that particular PARAFAC component will be the result of the fluorescence contribution from all those compounds with similar EEM. This issue is relevant when analysing degradation experiments where oxidation by-products with slight structural differences to the parent pollutant (e.g. a hydroxylation) are formed.

Noteworthy, although fluorescence is very sensitive and easy to measure, we have to consider the unavoidable interferences previously mentioned (section 1.7.1) which might be reflected in the final analysis. Therefore, inner filter effect corrections or the separation/elimination of, for instance, metals, as well as the use of buffer solutions to analyse the whole dataset at fixed $\mathrm{pH}$, should always be evaluated. This is even more important when dealing with AOPs, such as Fenton processes, where abrupt $\mathrm{pH}$ changes occur and there is a significant amount of iron that can be chelated by the fluorophore(s) [118,119]. Further EEMPARAFAC data processing details are thoroughly described in section 2.4.2 from the Experimental chapter. 
1.7.2.2.1. Examples of the EEM-PARAFAC use within the water treatment studies

As introduced in section 1.3.1, despite the paramount importance of DOM analysis, the most commonly employed methods for their monitoring within DWTP and WWTP are based on non-specific measurements such as conductivity, total organic carbon (TOC) or ultraviolet absorbance at $254 \mathrm{~nm}$ (UVa), which provide just limited information on the behaviour of the organic matter. Therefore, implementing new analytical techniques able to provide deeper layers of information on the composition of DOM whilst being sensitive, fast and low cost becomes necessary.

Works proposing the use of fluorescence spectroscopy in combination with chemometric tools have been carried out for the last 15 years. As previously mentioned, EEM is a threedimensional plot of fluorescence intensity for each combination of excitation and emission wavelengths. This is an important advantage of EEM against, for instance, UVa when studying samples with DOM from different sources, since the latter is not able to differentiate between compounds with similar absorption spectra, while this might be possible if they differ in their EEM. Moreover, important interferences, such as high concentration of $\mathrm{NO}_{3}{ }^{-}$, which also have considerable absorption at $254 \mathrm{~nm}$, will give an uncertain idea of DOM amount when using only UVa [15].

Traditionally, the different types of DOM in a EEM were identified and quantified based on the visible peak-picking method [120]. However, when increasing the quantity of data in presence of overlapping spectrums, as well as other interferences, a more sophisticated analysis was required. In this sense, different methods have been tested for EEM signal deconvolution, such as PCA, Artificial Neural Networks and PARAFAC, being the latter the most commonly employed [121]. Due to the second-order advantage, these methods can mathematically deconvolute the true spectra of the compound(s) of interest (as well as distinguish unknown ones) in presence of uncalibrated spectral interferences. Noteworthy, they also require a solid programming background, a major drawback which, nevertheless, has been overcome with several published free-access graphical user interface (GUI) programs [122,123], allowing unexperienced users to run the complex equations managed by software such as MATLAB ${ }^{\odot}$, but with a user-friendly program (Figure 1.17). 


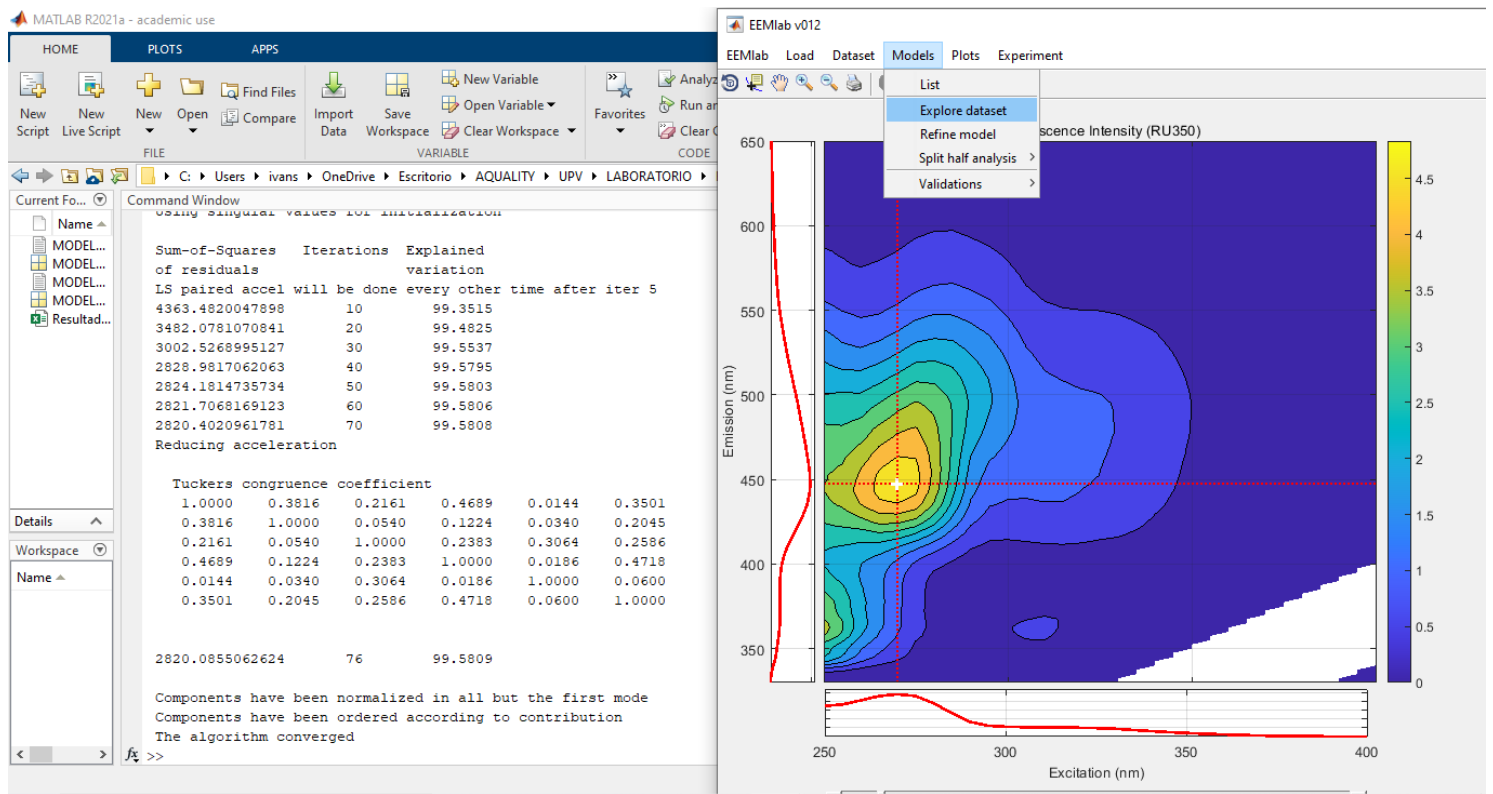

Figure 1.17. Example of EEMlab GUI employing drEEM toolbox [122] on MATLAB to run PARAFAC in an easier way without the need of having programming knowledge.

EEM-PARAFAC applicability covers mostly characterization and monitoring of fluorescent DOM in water bodies such as rivers, oceans, lakes, WWTP and DWTP. Detected components are within a variety of humic, fulvic, microbial and aminoacidic-like compounds, thus providing outstandingly useful qualitative and semi-quantitative insights on the chemical composition, as well as their changes, in complex water samples [124]. In Figure 1.18 a map from the different regions where the EEM maximums from the aforementioned types of DOM is shown.

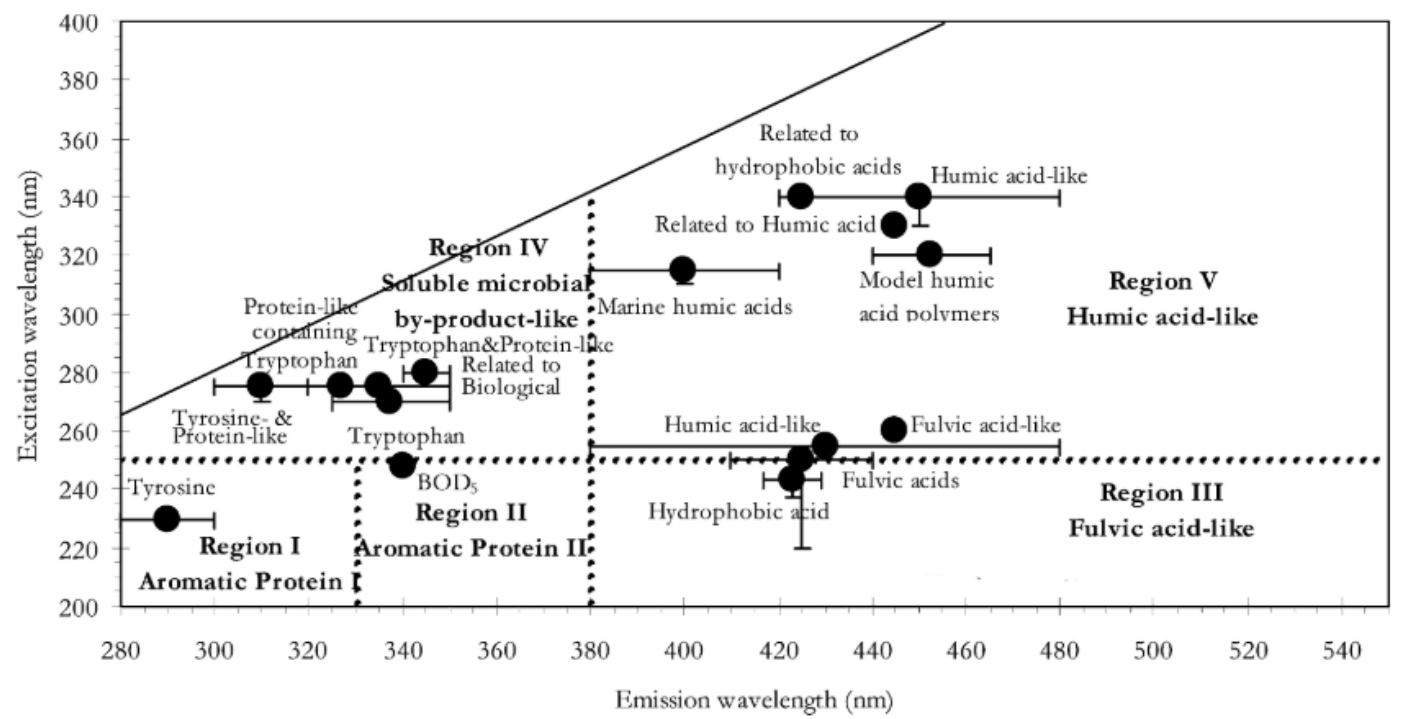

Figure 1.18. Typical fluorescent DOM EEM maximums (also considering second excitation maximums) regions [125].

The types of DOM that are usually found in WWTP significantly differ from the ones in DWTP. For the latter, water sources are natural aquatic environments, hence, DOM originated 
from terrestrial or plant material (humic-like substances, HLS) predominates, whereas WWTP are enriched by organic matter derived from microbial activity, mainly tryptophan-like (TryL). In fact, fluorescence intensity ratio between Try-L and HLS is a parameter to rapidly classify the water origin, being Try-L:HLS higher in the inlet of a WWTP, minor at the effluent, and much lower compared to the one of a river or potable water [126]. In line with these statements, biological oxygen demand is reported to exhibit strong correlations only with TryL among the different stages of WWTPs, whereas with HLS is poor or moderate. Moreover, Sorensen et al., 2018 proposed that Try-L fluorescence signal can be easily used as a fast and continuous indicative of drinking water faecal pollution or cross-connections between potable and reclaimed water systems, due to its correlation with thermotolerant coliforms (e.g. E. coli) [127]. However, according to authors, Try-L threshold seems to be still high, hence, further efforts towards sensitivity enhancement are needed.

EEM-PARAFAC has also shown a good correlation between DOM and CEC removal [128], as well as with generated DBP [124]. Moreover, this methodology is also able to detect changes in the composition of DOM associated with abrupt weather changes, such as rainy [129] or freezing periods [130].

This methodology can also be useful by analysing the individual behaviour of every DOM during the different water treatment steps. For instance, it was reported that the coagulation/flocculation process in DWTP significantly drops fluorescence signals from HLS but not from protein-like ones. On the contrary, on some occasions, it was observed that biological and chemical treatments reduce Try-L substances score values but with an increment of HLS ones [124]. This shall indicate that one type of DOM can be transformed into another and/or generate by-products that have similar EEM to another DOM, hence, increasing the scores of the other fluorophore due to impossible/poor signal deconvolution.

In line with the above mentioned statements, chemical oxidation and AOPs have not only shown fluorescence intensity decrease for some types of DOM, but also an enhancement. Due to the complex and varied molecular structures of DOM, as well as the multiple parallel reactions that might be occurring, there is still a great discrepancy between reported results.

Świetlik and Sikorska, 2004, studied the fluorescence changes of hydrophilic and hydrophobic $\mathrm{HLS}$ after the treatment with $\mathrm{O}_{3}$ and $\mathrm{ClO}_{2}$, and observed differences according to the type of HLS as well as the employed oxidant. After ozonation of hydrophobic HLS, the EEM maximum exhibited a marked red-shift, which they attributed to the addition of 
substituents such as hydroxyl, carbonyl and carboxyl $\left(-\mathrm{OH},-\mathrm{C}=\mathrm{O}\right.$ and $\left.-\mathrm{CO}_{2} \mathrm{H}\right)$, whereas for hydrophilic ones, even though it was slight, the shift was towards shorter wavelengths (blueshift). On the other hand, with $\mathrm{ClO}_{2}$ treatment, both HLS fractions, hydrophobic and hydrophilic, showed a marked blue-shift, which was attributed to their cleave into molecules with smaller molecular weight, as well as a decrease in the degree of electron delocalization of the $\pi$-electron system.

Ozonation alone, $\mathrm{O}_{3} / \mathrm{TiO}_{2} / \mathrm{UV}$ and $\mathrm{TiO}_{2} / \mathrm{UV}$ also exhibited differences in fluorescence signals of DOM. When applying $\mathrm{O}_{3}$ alone, an overall fluorescence reduction was observed. The same happened when using the combined treatment, $\mathrm{O}_{3} / \mathrm{TiO}_{2} / \mathrm{UV}$, observing even a faster reduction of the overall fluorescence. However, when using $\mathrm{TiO}_{2} / \mathrm{UV}$, there was a selective enhancement of certain substances [126]. Similarly, another study observed a reduction of PARAFAC score values of one component with the proportional increment of another one after oxidation with $\mathrm{TiO}_{2} / \mathrm{UV}[132]$.

EEM-PARAFAC is still in constant improvement, with its application with real-time continuous monitoring [133], machine learning [134], or even for laboratory-scale fluorescence of CECs simultaneous degradation analysis employing AOPs: from heavy polycyclic aromatic hydrocarbons [135], polyphenols [136] to FQs antibiotics [119,137], the latter shown in the Results and Discussion chapter. Therefore, besides from the simultaneous monitoring of the several parent pollutants that can be obtained in a simple, economical and fast way, it can also be elucidated the plausible molecular changes when observing new deconvoluted components corresponding to oxidation by-products. Correlation between PARAFAC score values and ROS formation could be another interesting application for fluorescent photosensitizers [138]. 



\section{CHAPTER 2 EXPERIMENTAL}





\section{Experimental}

Along this chapter, the fundamentals of the different main analytical techniques and equipment employed in the development of the $\mathrm{PhD}$ Thesis, are briefly described. The complete experimental specifications (whole employed reagents, their purposes, and the equipment's operational parameters and procedures) are described in the framework of the different articles included in Chapter 4.

\subsection{Irradiations}

Different lamps can be used. Ultraviolet lamps can be UVC, UVB and UVA, with maximum emission maximums at ca. 250, 300 and $365 \mathrm{~nm}$, respectively. On the other hand, for simulated sunlight, Xe lamps are employed, emitting light in the UV-visible region. As an example, in Figure 2.1, the emission spectrums for real sunlight and Xe, as well as UVB and UVA lamps is shown.

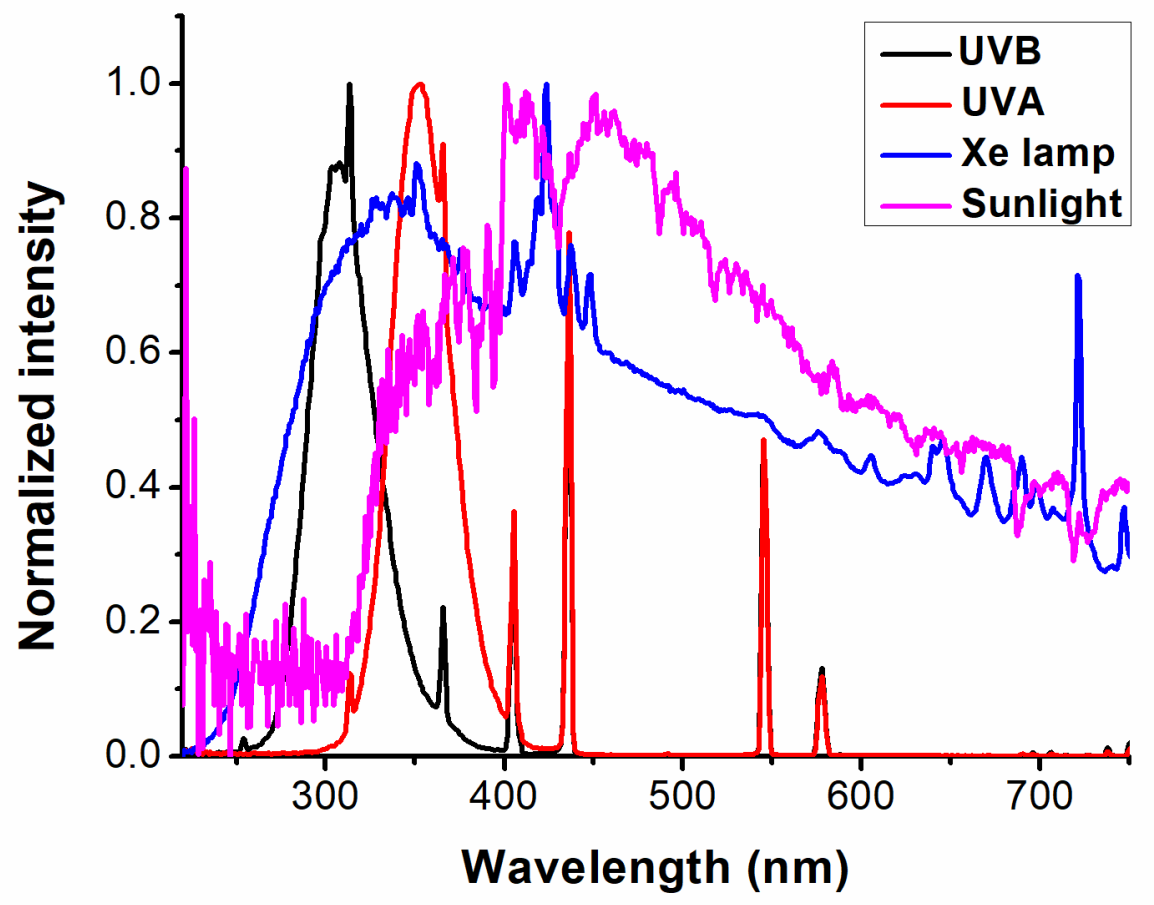

Figure 2.1. Normalized emission spectrums (measured with a charge-coupled device spectrophotometer, Ocean Optics USD 2000CUV-VIS) for sunlight and different lamps: UVB, UVA and Xe.

Approximating sunlight, a solar simulator is an equipment consisting of a lamp of Xe, lens, mirrors and filters (Figure 2.2A). Basically, these equipments have an ellipsoidal reflector able to collect ca. of $70 \%$ of the total lamp's radiation. This one is focalized with an optical integrator, producing a divergent beam, which afterwards is collected and focalized by lens in the working plane [139]. 
Two different solar simulators were used: Lot-Oriel LS0306 equipped with a highpressure Xe short arc lamp Ushio UXL-302-O (300 W intensity) (section 4.1), an Oriel Instrument (picture shown in Figure 2.2B) with the same lamp as the latter (section 4.3 and 4.4), and an Atlas Suntest XLS+ solarbox to perform a photo-Fenton during ZVI treatment trains (section 4.7).
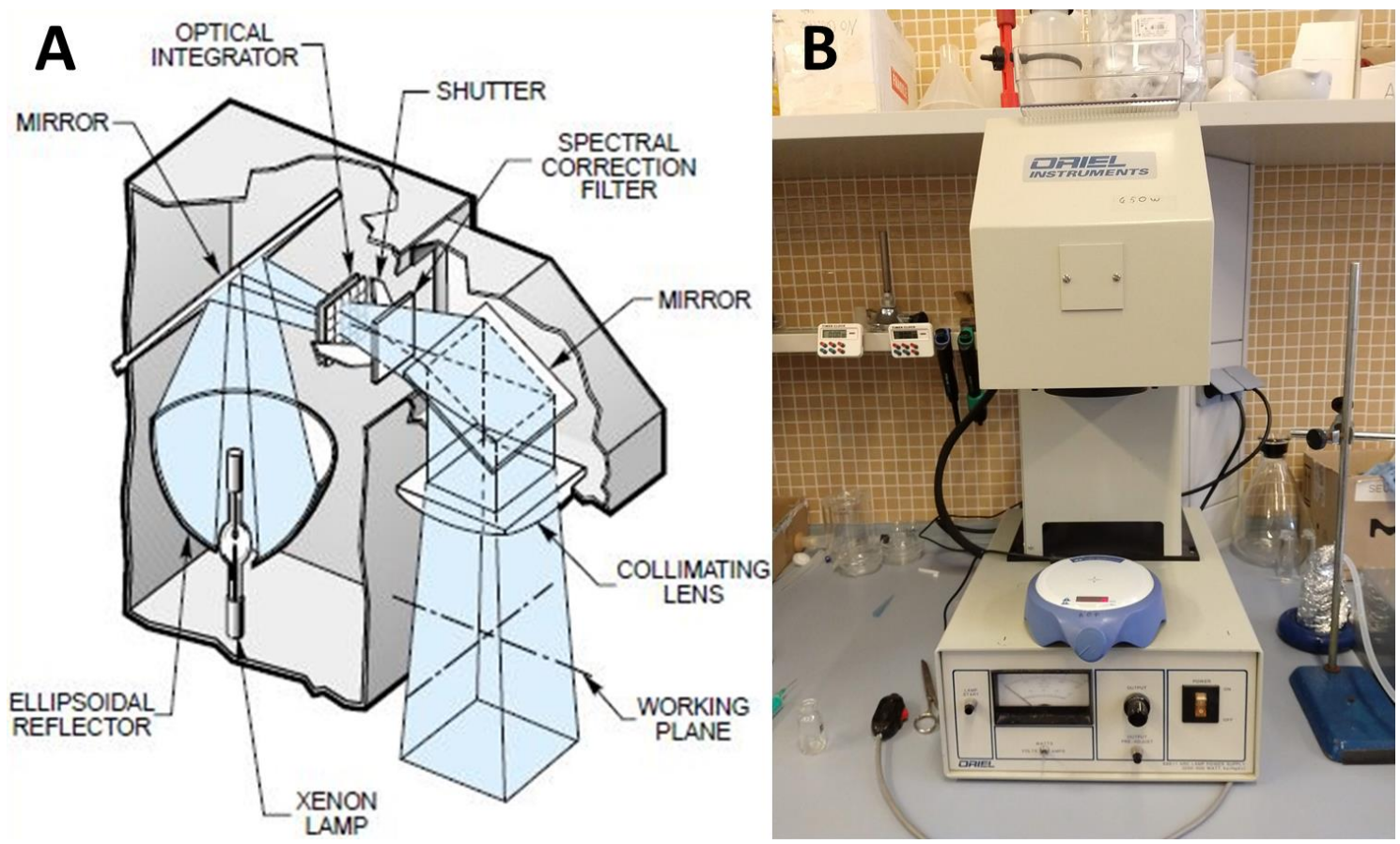

Figure 2.2. A) Scheme of an Oriel Instrument solar simulator components; B) frontal picture.

FQs irradiations performed at pilot plants were two: one of $45 \mathrm{~L}$ equipped with a $325 \mathrm{~W}$ low-pressure UVC lamp (ATG) (pilot plant details described in section 4.2), and the other was carried out in a reactor based on compound parabolic collectors (CPC) (Solardetox Acadus2001) used for the solar-photo-Fenton experiments shown in section 4.5. For the latter, solar radiation is reflected in a borosilicate glass tube, where the polluted water passes, placed on the focus of a double parabola reflector (concentration factor of 1), hence, illuminating the complete perimeter of the tube without solar tracking, and so, collecting the direct and diffuse radiation (Figure 2.3) [57,84]. 

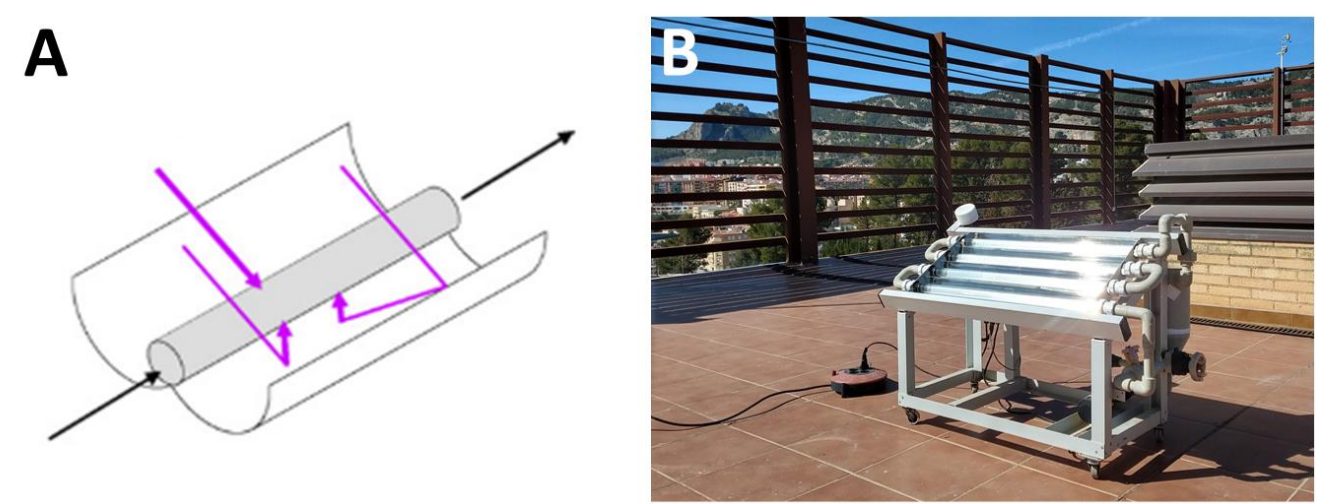

Figure 2.3. CPC reactor: A) radiation collection scheme, taken from S. Malato et al., 2009 [57]; B) picture of the employed $5 \mathrm{~L}$ pilot plant Solardetox Acadus-2001.

The mirrors of this device are made of anodized aluminium, a robust material resistant to harsh conditions and that possesses high UV reflectivity. The absorber tube is made of borosilicate glass, which exhibits a higher UV transmittance than normal glass. Moreover, due to the changing solar conditions, the irradiation time is usually measured as Eq. 2.1, where $L_{a c}$ is the accumulated irradiation (W min), $V_{i}$ the irradiated volume $\left(\mathrm{m}^{3}\right), S_{i}$ the irradiated surface $\left(\mathrm{m}^{2}\right)$ and $V_{T}$ the total volume $\left(\mathrm{m}^{3}\right)$. The accumulated light is therefore normalized by the solar average intensity, $L$, which is reported to be $30 \mathrm{~W} \mathrm{~m}^{-2}$ in Southern Spain [140,141].

$$
t_{30 W}=\frac{L_{a c} V_{i}}{L V_{T} S_{i}}
$$

\subsection{Total organic carbon (TOC) analysis}

The total amount of organic carbon, NOM, in a sample can be easily measured as the total amount of elemental carbon (defined as total organic carbon, TOC), they contribute with. In the case where the sample was previously filtered, the value shown by the instrument is called total dissolved organic carbon (DOC).

TOC value is obtained through the difference between total carbon (TC) and total inorganic carbon (TIC). In all cases, the equipment only measures $\mathrm{CO}_{2}$ with a non-dispersive infrared detector, which is afterwards translated into TC or TIC values.

Once the sample has been injected into the equipment, flows through an oven at $680^{\circ} \mathrm{C}$, transforming the $\mathrm{TC}$ in $\mathrm{CO}_{2}$, which is entrained in a high purity airflow up to the detector. On the other hand, for TIC determination, the sample is mixed with $\mathrm{H}_{3} \mathrm{PO}_{4} 25 \%$, hence, displacing the equilibrium from (bi)carbonates into $\mathrm{CO}_{2}$, purged by the airflow in the solution and afterwards analyzed in the detector [142]. 
In those samples in which the TIC content is quite high, TOC must be accurately obtained by measuring NPOC (non-purgeable organic carbon after acidifying and purging with air to eliminate inorganic carbon), where the solution is mixed with the $\mathrm{H}_{3} \mathrm{PO}_{4} 25 \%$ and afterwards directed in the oven.

In this work, TOC measurements were not only employed to measure the content of NOM in a water matrix (as in section 4.6, with a Shimadzu TOC- $\mathrm{V}_{\mathrm{CPH}}$ ), but mainly to determine the CECs' mineralization degree under a certain treatment and condition (sections 4.2, 4.3 and 4.4 employing Shimadzu TOC-V). TIC determinations were of particular importance mainly in section 4.7 (Shimadzu TOC-VCN) to understand the effect of (bi)carbonates during the reduction of p-nitrobenzoic acid by zerovalent iron microparticles.

\subsection{Spectrophotometric determinations}

Spectrophotometry was employed to measure changes during a certain reaction (e.g. absorbance changes with $\mathrm{pH}$ or with time under degradation processes), correct inner filter effects during EEM-PARAFAC pre-processing, and determine the concentration of iron and hydrogen peroxide.

Four different spectrophotometers were employed along this work: Varian Cary 3 (section 4.1), Hach-Lange (section 4.2), Hitachi-UH5300 (section 4.3 to 4.5) and Evolution 220 Thermo Scientific (section 4.7).

\subsubsection{Iron analysis}

Towards photo-Fenton processes, iron determinations are mandatory, hence, their measurements can be found in almost every section from the Results and Discussion Chapter. Dissolved and colloidal iron amounts are obtained when filtrating, and not, the solution through $0.45 \mu \mathrm{m}$ filters, respectively. Iron lixiviation from ZVI has also been studied (section 4.7). In particular, $\mathrm{Fe}^{3+}$ and $\mathrm{Fe}^{2+}$ individual measurements were relevant when analysing the LMCT transition of ENR-Fe ${ }^{3+}$ coordination complex (section 4.1).

$\mathrm{Fe}^{2+}$ can be determined spectrophotometrically by its complexation with specific chelating agents. The ones used in this PhD Thesis were 1,10-phenanthroline (ISO 6332:1988) and ferrozine (adapted from Viollier et al., 2000 [143]), absorbance maximums at 510 and 561 $\mathrm{nm}$, respectively. Their chemical structures are shown in Table 2.1, and in Figure 2.4 the typically obtained calibration curves examples for each case. 
$\mathrm{Fe}^{3+}$ measurement is obtained as the difference between total iron $\left(\mathrm{Fe}_{\text {total }}\right)$ and $\mathrm{Fe}^{2+}$ alone. Ascorbic acid is normally used as a reductive agent.

Table 2.1. $\mathrm{Fe}^{2+}$ spectrophotometric determination, chelating agents' molecular structures.

1,10-phenanthroline
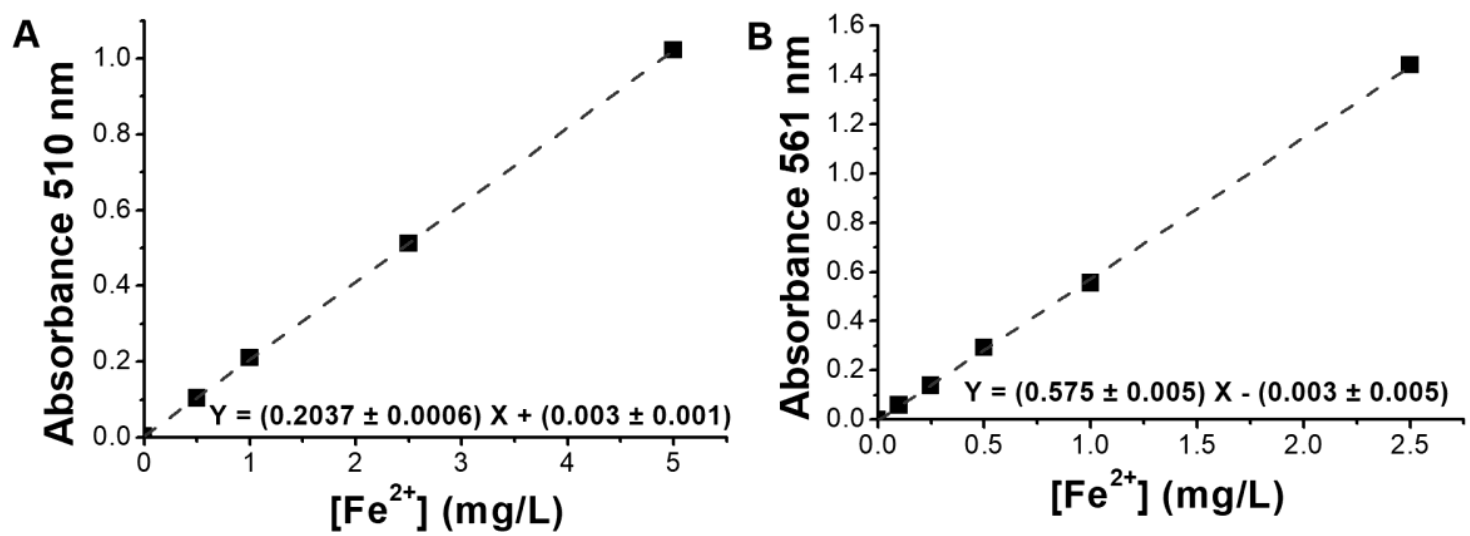

Figure 2.4. Calibration curves for iron spectrophotometric determination employing method: A) 1, 10phenanthroline, B) ferrozine.

\subsubsection{Hydrogen peroxide analysis}

As well as for iron, $\mathrm{H}_{2} \mathrm{O}_{2}$ determinations are relevant towards Fenton-related studies in order to measure the $\mathrm{H}_{2} \mathrm{O}_{2}$ consumption.

In the experimental work of this $\mathrm{PhD}$ Thesis, $\mathrm{H}_{2} \mathrm{O}_{2}$ concentration was determined by two different methods: one adapted from Nogueria et al., 2005 [144], employing ammonium metavanadate reagent $\left(\mathrm{NH}_{4} \mathrm{VO}_{3}\right)$, which is oxidized by $\mathrm{H}_{2} \mathrm{O}_{2}$ into $\mathrm{VO}_{2}{ }^{3+}(\mathrm{R} 2.1)$, the latter with an absorbance maximum at $450 \mathrm{~nm}$; the other way was performed according to the DIN 
$38402 \mathrm{H} 15$ method, employing titanium (IV) oxysulfate $\left(\mathrm{TiOSO}_{4}\right.$ ), that in presence of $\mathrm{H}_{2} \mathrm{O}_{2}$ forms a complex with an absorbance maximum at $410 \mathrm{~nm}(\mathrm{R} 2.2)$ [145].

$$
\begin{aligned}
& \mathrm{H}_{2} \mathrm{O}_{2}+\mathrm{VO}_{3}{ }^{-}+4 \mathrm{H}^{+} \rightarrow 3 \mathrm{H}_{2} \mathrm{O}+\mathrm{VO}_{2}{ }^{3+} \\
& \mathrm{TiO}^{2+}+\mathrm{H}_{2} \mathrm{O}_{2} \rightarrow \mathrm{TiO}_{2}{ }^{2+}+\mathrm{H}_{2} \mathrm{O}
\end{aligned}
$$

Calibration curves obtained with $\mathrm{NH}_{4} \mathrm{VO}_{3}$ and $\mathrm{TiOSO}_{4}$ reagents are shown in Figure 2.5A-B, respectively. The techniques are not sensitive enough to determine photogenerated $\mathrm{H}_{2} \mathrm{O}_{2}$ (due to a photosensitizer).
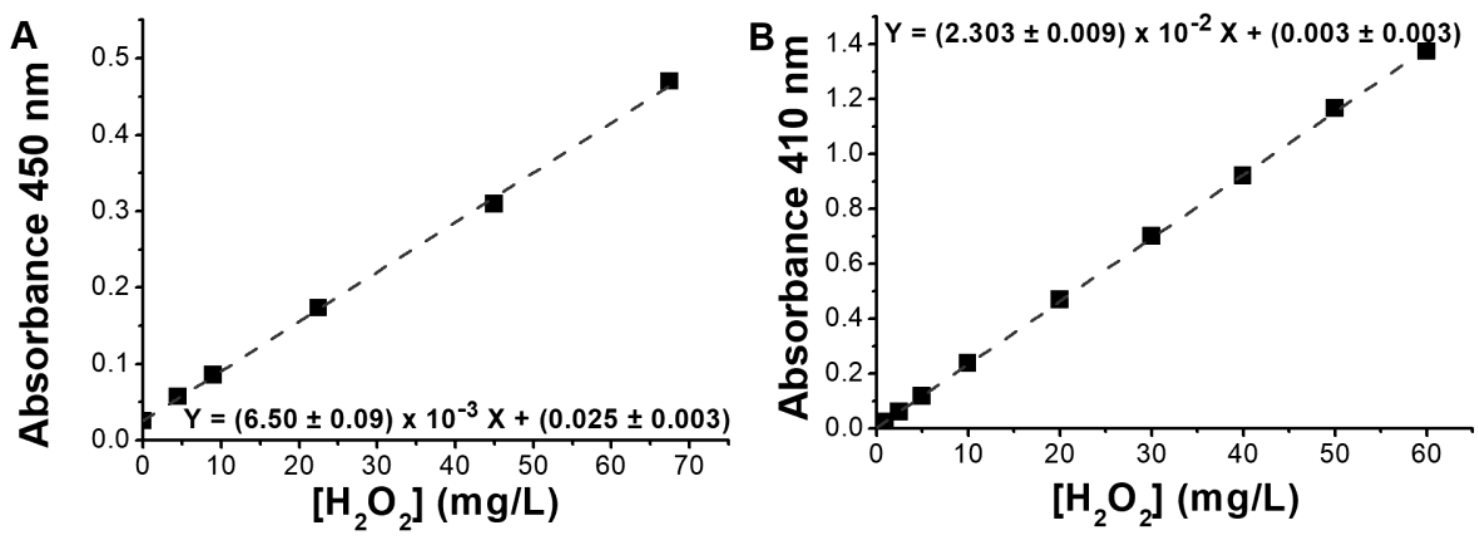

Figure 2.5. Calibration curves for hydrogen peroxide spectrophotometric determination employing method: A) $\mathrm{NH}_{4} \mathrm{VO}_{3}$, B) $\mathrm{TiOSO}_{4}$.

\subsection{EEM-PARAFAC}

This methodology was employed to characterize and track the changes of DOM along a DWTP (section 4.6), and to follow changes during FQs degradation studies (section 4.3 to 4.5). In all cases, a Horiba PTI Quanta Master 400 fluorescence spectrometer was employed to measure the EEM, and PARAFAC was carried out with MATLAB ${ }^{\mathrm{TM}}$ software through the GUI, EEMlab [122].

\subsubsection{Fluorescence spectrometer}

Conventional fluorescence spectrometers exhibit a light source, typically xenon (Xe), two monochromators and the detector. The first monochromator is placed between the Xe lamp and the sample (excitation monochromator) and the other between the sample and the detector (emission monochromator). The fluorescence emission is propagated in all directions, but the most convenient to observe is the one at $90^{\circ}$ from the incident light, as it reduces to the minimum the contributions from scattering and from the intense light source [113] (Figure 2.6). Therefore, by selecting one excitation wavelength (maximum absorbance) while rotating the second monochromator, one will obtain the fluorescence emission spectra, whereas in the 
opposite way, fixing one emission wavelength and rotating the excitation monochromator, the excitation spectra is obtained.
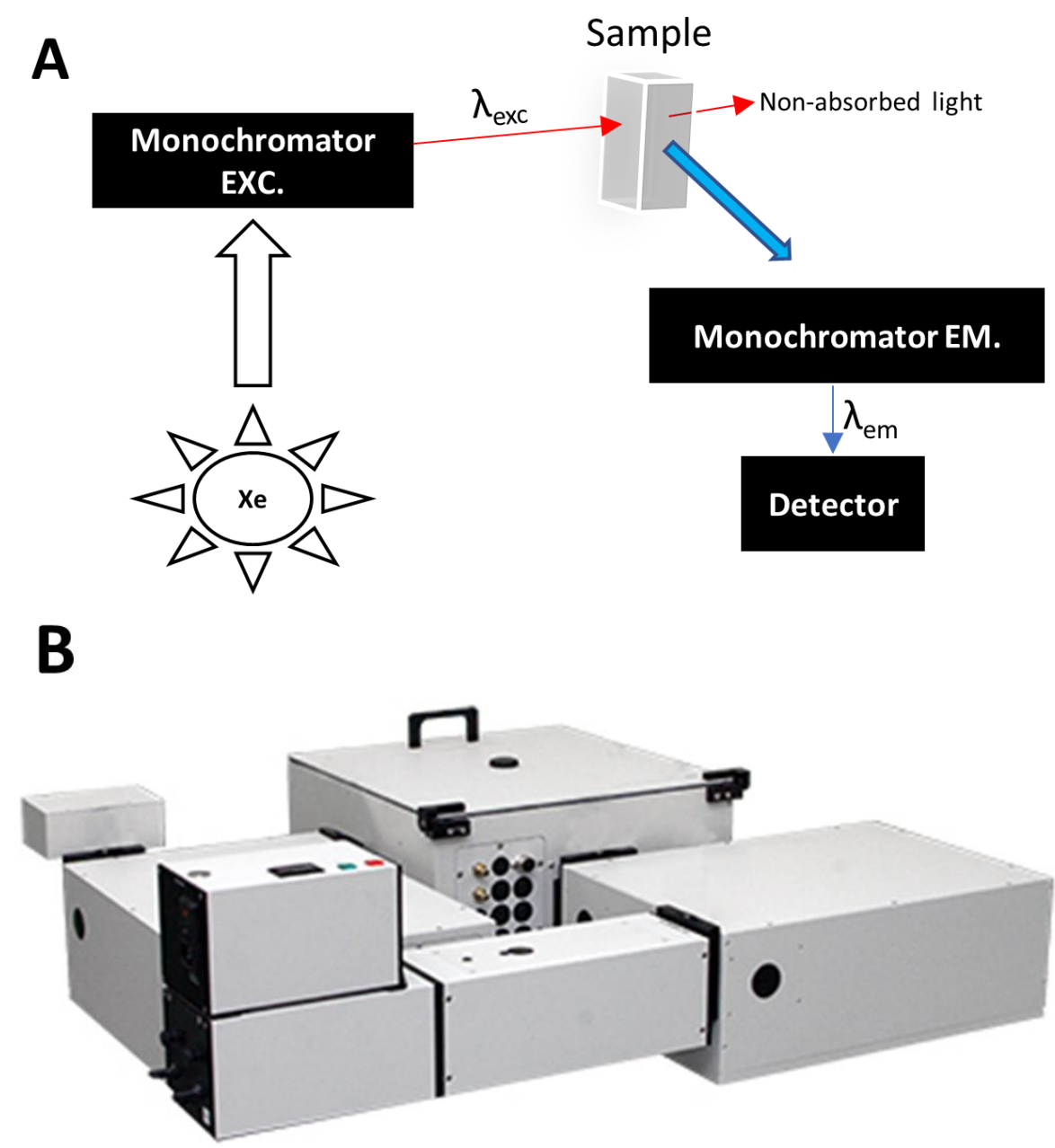

Figure 2.6. Spectrofluorometer of two monochromators: A) scheme; B) picture.

\subsubsection{EEM-PARAFAC data analysis}

As mentioned in section 1.7, there are several interferences in fluorescence, such as the inner filter effect or light scattering. Moreover, not all the fluorophores in the dataset might have the same fluorescence intensity due to quantum yield or concentration differences, reflected on a lower statistical weight when performing the PARAFAC analysis. Therefore, before running PARAFAC the user must detect all the weaknesses that shall not be considered or corrected. The issues to take into account are three:

1. Correct systematic biases.

2. Eliminate and correct non-trilinear data.

3. Normalize the fluorescence signals. 
The first issue, systematic biases, considers the errors associated with the imperfections in the equipment, for example, in the optical alignments, or due to light efficiency transmission changes through the monochromators. The EEM is therefore multiplied by a correction matrix, which some commercial fluorescence spectrometers do automatically. In addition, since the lamp's power is reduced over time, signals must be standardized every time, which could be performed with quinine emission signal or water Raman scatter peak at $350 \mathrm{~nm}$ [146]. Finally, another important issue to correct is the inner filter effect. To do so, the absorbance spectra from each sample, within the considered excitation and emission respective ranges, must be also uploaded into the dataset. For instance, if the EEM are measured in the range $250-400$ $\mathrm{nm}$ excitation axis and $300-600 \mathrm{~nm}$ emission axis, then the absorbance from each sample must be taken from 250 to $600 \mathrm{~nm}$.

The second step consists of correcting interferences due to the light scattering (Raman and Rayleigh). Primary Rayleigh does usually not overlap in the regions where there are fluorescence signals, and can be eliminated with missing values. On the contrary, secondary Rayleigh as well as both Raman bands, often overlap with fluorescence signals. In these cases, the correction can be more complex. Although data interpolation is usually the best choice, this manipulation can also eliminate fluorescence signals, or broaden them, causing mistakes by the time of modelling. A balance between using interpolation wavelength ranges and excision must always be considered.

Finally, shortly before starting the PARAFAC modelling, EEM must be normalized to their total signal. In this way, every fluorophore present in the dataset will exhibit the same leverage, allowing the model to focus on assessing to every component their particular EEM (their fingerprint) avoiding modelling mistakes due to low fluorescence signal intensity.

Once steps 1 to 3 have been carried out, the model itself can start with a first exploration, selecting the numbers of plausible components the dataset is suspected to contain. Within this preliminary modellings, outliers or preprocessing lacks can appear. One must therefore reverse the normalization, correct the possible interferences (usually due to Rayleigh and Raman poor corrections), and perform again the exploration modelling. This loop will be repeated until obtaining a convincing model, this is, when modelled fingerprints fits with the ones of the analytes/interferences, when the residuals error between the modelled EEM and the measured ones is low and randomly distributed, and there are no components with more than one emission maximum or any other chemical inconsistency. 
Once we have obtained the model we consider is suitable to explain all the dataset, it can be refined by performing a more restrictive PARAFAC run [122]. Finally, for choosing which one is the best option (for instance, between three possible models of 4,5 and 6 components that might be suitable after the refinement step) there are two main criteria that might help: CORCONDIA and the split-half analysis.

Besides the complex mathematical background behind CORCONDIA, it is mainly based on the concept that a model is only appropriate when adding additional components does not considerably improve the fit [147]. When plotting the CORCONDIA (expressed as a percentage) against the number of considered components for each of the tested and refined models, one will see two lines with negative slopes. The inflexion point between these two curves will be the correct number of components (see later Figure 4.23 or expressed as values in Table 4.3), being always CORCONDIA $=100 \%$ for the model with a single component. Although it is quite visual, for models with a big number of components (e.g., 5 or more) CORCONDIA might not always be reliable, as the model could be fitting and describing well the dataset but exhibiting low, or even negative, CORCONDIA's values. Therefore, it might be more useful in cases with under-fitting rather than with over-fitting.

The other method consists of dividing into halves the dataset in different ways. Each EEM is assigned to one of four splits. Afterwards, each of these splits can be combined with another one. For example, calling the splits A, B, C and D, we can make two types of combinations: $\mathrm{AB}$ vs. $\mathrm{CD}$ and $\mathrm{AD}$ vs. $\mathrm{BC}$, or all the possible ones, this is, $\mathrm{AB}$ vs. $\mathrm{CD}, \mathrm{AC}$ vs. $\mathrm{BD}$, and $\mathrm{AD}$ vs. BC. The test will create new PARAFAC models (using the number of components from the previous refined model we want to validate) for each of these subdatasets. Strictly, the refined PARAFAC model will be validated by the split-half analysis method only when the models from each sub-dataset for every combination are also valid. Micó et al., 2019, also propose the validation of split-half analysis in only one of the combinations (i.e. only in $\mathrm{AB}$ vs. $\mathrm{CD}$ but not in $\mathrm{AD}$ vs. $\mathrm{BC}$ ) under a certain threshold called Tucker's correlation coefficient [122].

All the necessary tools to perform every task described above, are contained in drEEM toolbox developed by K. R. Murphy and co-workers [117,148].

\subsection{Transient absorption spectroscopy}

Transient absorption spectroscopy, also known as flash photolysis, employs a short highenergy pulse with a LASER irradiation source, photoexciting the molecule to study. The latter 
is probed with pulses of lower intensities, thus monitoring the change in absorption (the excited state absorption minus the ground state one) for the probed wavelength range and for each time-delay between pulses, allowing temporal resolutions of $1 \times 10^{-8} \mathrm{~s}$. Negative bands indicate ground state absorption, whereas the positive excited state indicates absorption $[69,82]$.

In this $\mathrm{PhD}$ Thesis, transient absorption spectroscopy is employed in section 4.1 (Applied Photophysics-LKS60), to measure the quenching kinetic rate constants between the ENR's triplet excited states with dissolved oxygen $\left({ }^{3} \mathrm{O}_{2}\right)$.

\subsection{High-Performance Liquid Chromatography (HPLC)}

Chromatography collects an important and diverse number of methods which can facilitate the separation, identification and quantification of analytes. Briefly, the sample is dissolved in a so-called mobile phase (a liquid or a gas), which carries the compounds through a system (column, plate or capillary tube) containing a stationary phase.

For High-Performance Liquid Chromatography (HPLC), a continuous analyte mass transfer occurs between both phases, obtaining different median speeds for each compound in the sample, allowing their separation [113]. Once the different compounds constituting the injected sample reach the detector, it is finally obtained a chromatogram. Detectors can be several, all of them with different purposes, sensitivity and selectivity: UV/Vis absorbance, fluorescence emission, conductivity or coupled to mass spectrometry. In any case, the chromatogram's signals have a Gaussian distribution product of the different molecules' speed in the column. The media of the Gaussian signal corresponds to the retention time of that particular compound, and the area under the curve is proportional to the analytes' concentration [113].

HPLC-UV/Vis measurements were used to determine the removals of the FQs, analysing the individual area's signal decay. In section 4.1, a Shimadzu Nexera DGU-20A5R was employed, whereas in sections 4.2 to 4.5 , a Hitachi Chromaster. The p-nitrobenzoic acid (PNBA) and p-aminobenzoic (PABA) kinetics (section 4.7) were assessed with an Agilent 1100 series, and their respective calibration curves are shown in Figure 2.7. Ion chromatography Metrohm 850 Professional IC was employed to characterize the water matrices in section 4.7. As mentioned at the beginning of this Chapter, specifications (sample preparation, columns, modules and elution conditions) are described in each article included as sections in Chapter 4. 

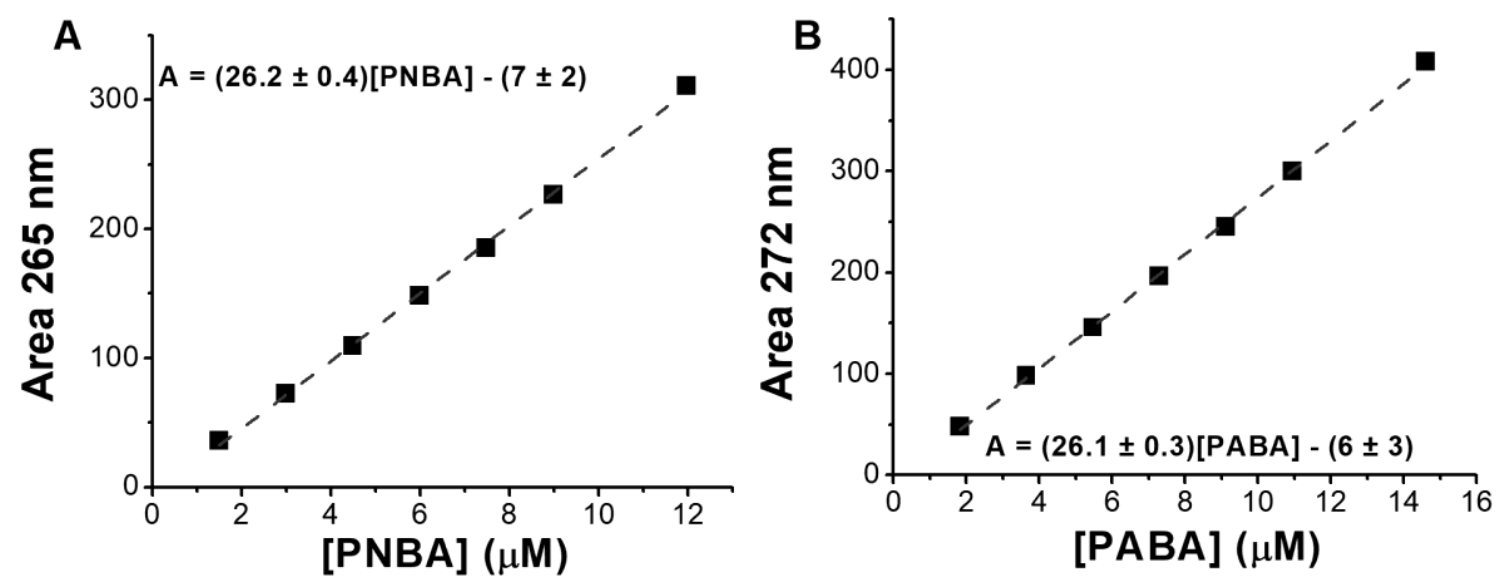

Figure 2.7. HPLC calibration curves for A) PNBA and B) PABA.

\section{7. $\quad$ Mass spectrometry}

Mass spectrometry (MS) is based on the fact that every substance can be volatilized. They can be coupled to an HPLC or gas chromatography, being very useful, not only because of its outstanding low detection limits $(\approx 0.5-10 \mathrm{ng} / \mathrm{L})$, but also since one could elucidatetentatively in case there is no standard - the molecular structure of unknown compounds present in the sample, such as degradation by-products or when it is employed for non-target analysis.

Basically, mass spectrometry is based on three steps: i) volatilization/ionization, ii) analysis, and iii) detection. The first one determines the type of compounds that can be analysed by the equipment, whereas the combination between analyzer and detector, the quality and reliability of the analysis.

As mentioned above, the volatilization/ionization step will depend on the substance, if it is thermolabile or thermostable, requiring soft (i.e. desorption) or strong (i.e. heat) methods, respectively. For this particular work, it is worthy to mention electrospray ionization (ESI). ESI is a soft volatilization method, extremely useful when coupling mass spectrometry with HPLC as the analytes carried by the mobile phase are directly ionized shortly before the analyzer. The liquid escapes from a capillary, which is also an electrode. The macro-drops spray enters in the electric field region between the capillary and the counter-electrode, suffering a contractionrepulsion explosion, which eventually leads to the desorption/volatilization of the analytes (Figure 2.8) [149]. At the same time, if the molecule is neutral, protonated or deprotonated, as well as if there is a relevant concentration of ions, such as $\mathrm{Na}^{+}$or $\mathrm{Cl}^{-}$, ionization could be on positive (i.e. $\mathrm{H}^{+}$or $\mathrm{Na}^{+}$adduct) or negative mode (i.e. $\mathrm{H}^{+}$loss or $\mathrm{Cl}^{-}$adduct). Examples for ionization in positive and negative modes are shown in R 2.3 and $\mathrm{R} 2.4$, respectively. 


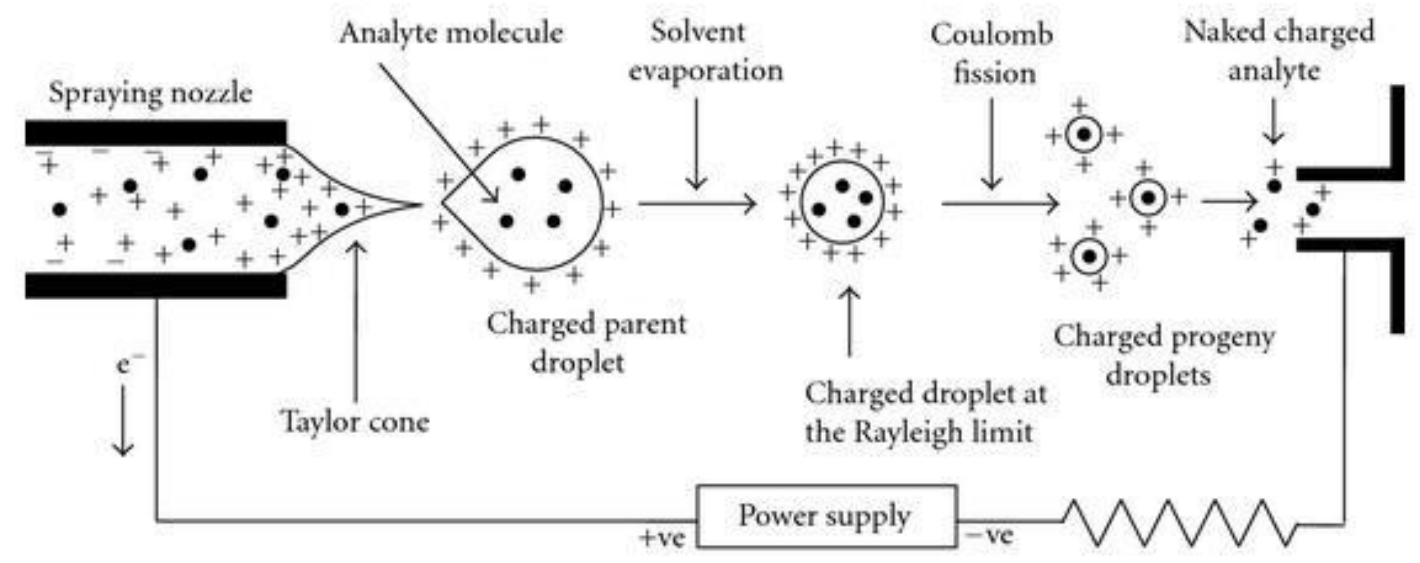

Figure 2.8. Scheme of an ESI [150].

$\mathrm{M}_{(\mathrm{aq})} \rightarrow \mathrm{M}_{(\mathrm{g})}+\mathrm{H}_{(\mathrm{g})}^{+} \rightarrow[\mathrm{M}-\mathrm{H}]^{+}(\mathrm{g})$

$\mathrm{M}-\mathrm{H}_{(\mathrm{aq})} \rightarrow \mathrm{M}-\mathrm{H}_{(\mathrm{g})} \rightarrow \mathrm{M}_{(\mathrm{g})}^{-}+\mathrm{H}^{+}(\mathrm{g})$

Analyzers could be several: quadrupole, time of flight, orbitrap, ion trap, etc. They can also be in tandem (MS/MS), measuring the compound's concentration as well as fragmenting it in order to elucidate its molecular structure (i.e. triple quadrupole or quadrupole-time of flight). The user will finally measure the analyte, and fragments, mass-charge ratio $(\mathrm{m} / \mathrm{z})$.

For this $\mathrm{PhD}$ Thesis, MS was employed to elucidate the structure of formed transformation products during the photolysis of ENR (results in section 4.1). The employed equipment was a Bruker SolarixXR Fourier Transform Ion Cyclotron Resonance (FT-ICR) 9.4 T. Measurements were performed by Dr. Zsuzsanna Varga, hence, its way of action and related information are not explained in this work.

\subsection{Antibacterial activity}

The zone of inhibition test, or Kirby-Bauer method, is a simple analysis to measure the microbiologic potency of a given antibiotic. In this $\mathrm{PhD}$ thesis, we have used it to determine the degradation degree of FQs with the different employed treatments (sections 4.3 and 4.4). The bacteria (e.g. Escherichia coli) is spread on an agar plate where wells are afterwards made. In each well, the testing solution is placed and, after an incubation period, the inhibition halo diameter (where the bacteria have not grown) is used as an indicator of the antibacterial activity of that particular sample.

In Figure 2.9 an example for ENR degradation with different processes is shown. It can be seen how the inhibition halo diameters are reduced in time differently with each water 
treatment, being negligible with photolysis (Figure 2.9A) but marked with photo-Fenton

(Figure 2.9B), indicating that the latter is more efficient towards antibiotic degradation.

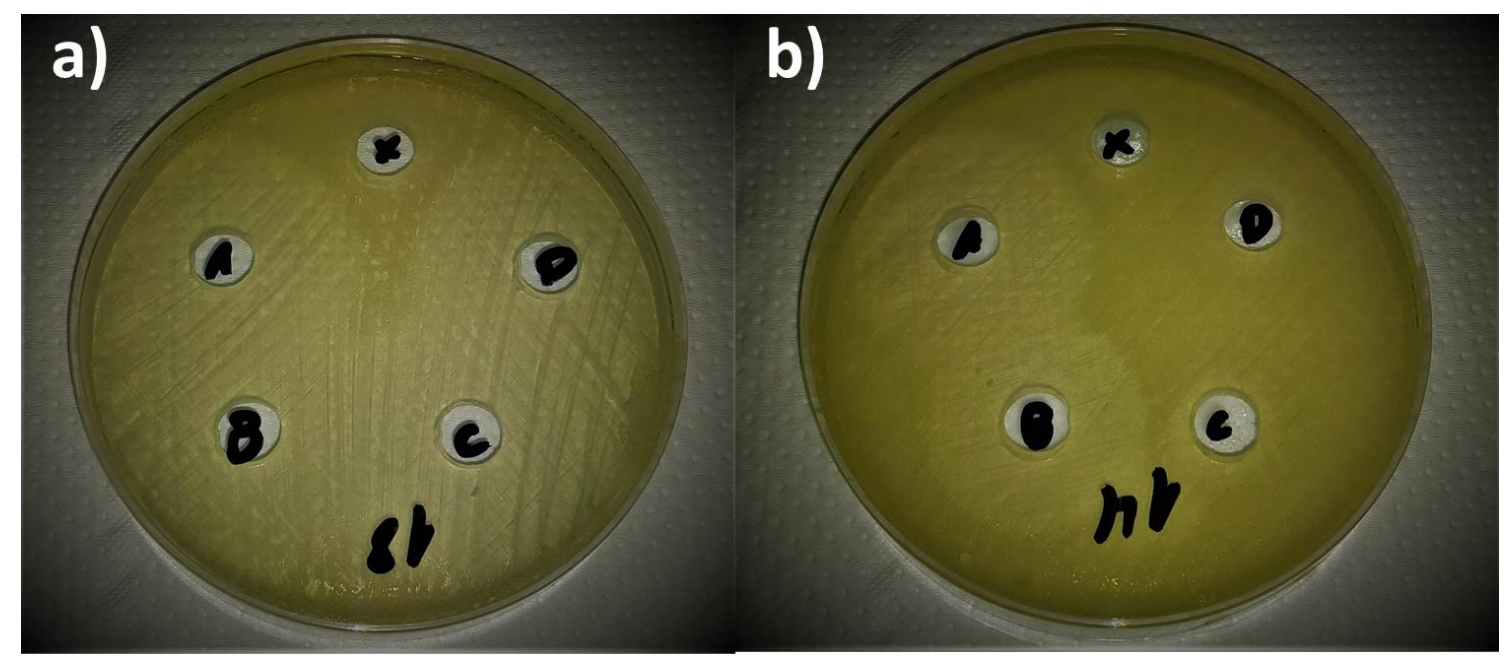

Figure 2.9. Antibacterial activity example for ENR $25 \mathrm{mg} / \mathrm{L}$. In all cases, in the well X control sample (water alone) was added, whereas in $A, B, C$ and $D$ wells the degradation times $0,15,30$ and 60 minutes for: a) photolysis; b) photo-Fenton. 



\section{CHAPTER 3}

OBJECTIVES 



\section{3. $\quad$ Objectives}

The main objective of this $\mathrm{PhD}$ Thesis is to study the use of AOPs employing iron to degrade CECs. The specific objectives can be described as following:

- Evaluating the effect of iron on a FQ towards its photolysis: compare the photolytic rates by simulated sunlight of a FQ (ENR) at different $\mathrm{pH}$ values, in the presence and absence of $\mathrm{Fe}^{3+}$, analysing in each case the plausible formation of ROS and the effect of $\mathrm{H}_{2} \mathrm{O}_{2}$ addition.

- Testing a new photocatalytic material consisting of a core of $\mathrm{SiO}_{2} / \mathrm{Fe}_{3} \mathrm{O}_{4}$ coated with $\mathrm{TiO}_{2}$ for tertiary wastewater treatment at pilot plant scale equipped with an UVC lamp against a FQ (ENR) as well as water disinfection (elimination of Escherichia coli and Clostridium perfringens). Study the different operational conditions, analysing the effects of photocatalyst quantity, $\mathrm{pH}$ and recirculation flow rates. Compare the results against: (i) irradiation alone, (ii) $\mathrm{H}_{2} \mathrm{O}_{2} / \mathrm{UVC}$, (iii) Fenton, and (iv) photo-Fenton process.

- Studying ZVI-based treatment trains for pollutant abatement (prereduction/Fenton oxidation) to degrade a recalcitrant pollutant (p-nitrobenzoic acid). Evaluate the different conditions governing each step, and the convenience of separating, or not, the ZVI after the pre-reductive process. Overall advantages and lacks this approach shall be assessed.

On the other hand, most efforts along this $\mathrm{PhD}$ Thesis were destined to the use of EEMPARAFAC towards the analysis of FQs degradation employing Fenton and (solar-)photoFenton processes in different water matrices, $\mathrm{pH}$, and number of present FQs as well as different concentrations. The use of this tool was studied following the next strategy:

- Comparing the fate of a single FQ (ENR) by direct photolysis, Fenton and photoFenton processes (employing simulated sunlight) in different water matrices (ultra-pure water, tap water and salty water) and $\mathrm{pH}$ values (2.8 and 5.0). Analyse the fluorescence trend of the EEM of the parent pollutant, as well as observe the EEM fingerprints and scores associated with the oxidation by-products appearing during each degradation process. Correlate EEM-PARAFAC with HPLCUV/vis, TOC and bioassays. 
- Studying the degradation of a mixture of 3 FQs (ENR, OFL and SAR) employing photolysis, $\mathrm{H}_{2} \mathrm{O}_{2} / \mathrm{h} v$, Fenton and photo-Fenton, using a solar simulator, in ultrapure water, and at three different $\mathrm{pH}$ values: 2.8, 5.0 and 7.0. Try to analyse, simultaneously, the decay of the fluorescence signals of the three parent pollutants plus the scores profile of generated by-products.

- Carrying out solar-photo-Fenton at pilot plant scale to degrade a mixture of $5 \mathrm{FQs}$ (ENR, CIP, OFL, FLU and OA) in different water matrices (ultra-pure, salty and simulated wastewater). Study the effect of adding humic-like substances isolated from olive mill wastes (HLS-OMW) as an iron-chelating agent. Evaluate the ability of PARAFAC to also deconvolute uncalibrated Thiabendazole (TBZ) fingerprint as a fluorescent interference.

- Employing the classical use of EEM-PARAFAC: characterize and track the changes of DOM fractions along the different stages of a DWTP. 


\section{CHAPTER 4}

RESULTS AND DISCUSSION 



\section{Results and discussion}

\subsection{Significant role of iron on the fate and photodegradation of Enrofloxacin}

This section contains information from the publication referenced as [118]: Sciscenko, Iván; Arques, Antonio; Varga, Zsuzsanna; Bouchonnet, Stephane; Monfort, Olivier; Brigante, Marcello; Mailhot, Gilles. Significant role of iron on the fate and photodegradation of Enrofloxacin.

Chemosphere

2021,

270 ,

129791.

https://doi.org/10.1016/j.chemosphere.2021.129791

The results of this section were obtained during the secondment carried out at UCA under the supervision of Dr. Gilles Mailhot, Dr. Marcello Brigante and Dr. Olivier Monfort. In particular, MS/MS measurements and its data analysis were performed in collaboration with an AQUAlity beneficiary, the École Polytechnique (Palaiseau, France) by Dr. Zsuzsanna Varga and Dr. Stephane Bouchonnet.

\subsubsection{Introduction}

Since metals can modulate the pharmacological and physicochemical properties of these compounds, synthesis and characterization of FQ-metal complexes has been thoroughly studied to obtain better antibiotics and expand FQs applicability [151-153]. Photochemical properties could also be affected, as shown by Cuquerella et al., 2010 with $\mathrm{Cu}$ (II) and rufloxacin complex.

Density Functional Theory (DFT) calculations have shown that the complex formed between one of the most frequently found in natural effluents, the enrofloxacin (ENR), with $\mathrm{Mg}^{2+}$, presented higher activation energies for the most direct photolysis pathways than ENR itself [155]. Similarly for ciprofloxacin, another highly consumed FQ, which is also the main photoproduct of ENR [156], in presence of $\mathrm{Cu}$ (II) exhibited a strong photolytic inhibition, only recovered in presence of EDTA [157]. On the contrary, $\mathrm{Cu}(\mathrm{II})$ increased by a factor of 2.4 the photolytic rate constant of moxifloxacin [158], thus indicating that FQ-metal photochemical behaviour could also be dependent on the antibiotic molecular structure.

During photo-Fenton studies, when the pollutant is photolabile, photolysis degradation contribution must be also considered. However, although many studies of FQs oxidation by photo-Fenton had been published [159], the individual effect of iron towards FQs' 
photochemical fate is practically unexplored. For instance, Qiu et al. 2019 [160], when treated two FQs and another type of antibiotic by UV/Fe(III), it can be seen that for the tested FQs its removal rate was much more sensitive to the iron concentration variation compared to the other non-FQ antibiotic. According to the above mentioned statements, this could had been most likely related to the downplayed FQ-iron interaction, not present in the case of the other compound. In this regard, FQs Fenton degradation has been reported as effective even at mild $\mathrm{pH}$ conditions due to iron chelation by the pollutant itself [137].

In this work, we decided to compare the photochemical fate of ENR under sun-simulated conditions alone and as Fe(III)-complex. First, spectroscopic characterization and stability of the complex between ENR and Fe(III) was assessed, secondly, photochemical degradation of ENR and its Fe(III)-complex was evaluated with and without addition of hydrogen peroxide. Finally, the main photoproducts were characterized, and a schematic degradation pathway was proposed. Besides the environmental aspect, we believe that these results will be useful to better comprehend the behaviour of FQs degradation by photo-Fenton and analogues processes.

\subsubsection{Experimental}

\subsubsection{Reagents}

High purity (> 99\%) enrofloxacin (ENR), $\mathrm{Fe}\left(\mathrm{ClO}_{4}\right)_{3} \cdot \mathrm{xH}_{2} \mathrm{O}, \mathrm{NaOH}$, ferrozine, ascorbic acid and furfuryl alcohol (FFA) were purchased from Sigma-Aldrich. Isopropyl alcohol (IPA), formic acid $98 \%, \mathrm{H}_{2} \mathrm{SO}_{4} 98 \%$, and HPLC grade, methanol and acetonitrile, were obtained from VWR Chemicals. When specified, filtration was performed employing Chromafil Xtra PTFE $0.45 \mu \mathrm{m}$ filters and no significant ENR retention (i.e. adsorption on the filter) was determined. All the solutions were prepared with ultra-pure water $(18.2 \mathrm{M} \Omega \mathrm{cm})$.

pH was adjusted with $\mathrm{H}_{2} \mathrm{SO}_{4} 0.05 \mathrm{M}$ or $\mathrm{NaOH} 0.1 \mathrm{M}$. Fe(III) $2 \mathrm{mM}$ stock solutions were prepared from $\mathrm{Fe}\left(\mathrm{ClO}_{4}\right)_{3} \cdot \mathrm{xH}_{2} \mathrm{O}$ solid each day. Stock solution of ENR was prepared in acidic water at $\mathrm{pH}$ 2.0. Iron-ENR solutions were prepared $10 \mathrm{~h}$ before each experiment. All the solutions were kept in dark conditions and final preparations were performed just before experiments.

\subsubsection{Chemical analysis}

ENR concentration was monitored by a Shimadzu Nexera DGU-20A5R high performance liquid chromatography (HPLC) coupled with a photodiode array (PDA) detector. 
A C18 Macherey-Nagel column Nucleodur $-\pi^{2} 5 \mu \mathrm{m}$ was used with a $0.25 \mathrm{~mL} \mathrm{~min}^{-1}$ isocratic flow of $85 \%$ formic acid $0.1 \mathrm{M}$ and $15 \%$ acetonitrile. The oven was set at $40^{\circ} \mathrm{C}$ and detection of ENR and FFA were performed at 278 and $227 \mathrm{~nm}$, respectively. ENR in presence or absence of $\mathrm{Fe}(\mathrm{III})$ has exhibited the same retention time in all cases.

Total iron and Fe(II) concentrations, were measured by Ferrozine method [143]. All UVvis spectra were acquired using a Varian Cary 3 UV-Visible spectrophotometer.

LC-MS and LC-MS/MS measurements were performed on a Bruker SolarixXR FT-ICR 9.4T ultra-high resolution mass spectrometer coupled to a Waters Acquity HPLC system. For the separation an Agilent Pursuit XRsULTRA C18 (length $50 \mathrm{~mm}$, diameter $2 \mathrm{~mm}$, particle size $2.8 \mu \mathrm{m}$ ) column was used with a flow of $0.2 \mathrm{~mL} \mathrm{~min}^{-1}$. Gradient elution was used starting with $95 \%$ of water with $0.1 \%$ formic acid and $5 \%$ of acetonitrile with $0.1 \%$ formic acid (95$5 \%$ ). This ratio was held up to 3 minutes, after that it was gradually changed to $50-50 \%$ up to 12 minutes, and altered to 5-95\% until 17 minutes of elution. Electrospray ionization source was used in positive mode, the capillary voltage was set at $4000 \mathrm{~V}$ and spray shield at $-500 \mathrm{~V}$. Nitrogen was used both as nebulizer gas at 1 bar, and drying gas at $8 \mathrm{~L} \mathrm{~min}^{-1}$ and $250^{\circ} \mathrm{C}$. The sample injection volumes were $2 \mu \mathrm{L}$ for LC-MS and $10 \mu \mathrm{L}$ for LC-MS/MS experiments. The $\mathrm{m} / \mathrm{z}$ detection range was between 57.7 and $1000 \mathrm{~m} / \mathrm{z}$. Data acquisition size was $4 \mathrm{Mpts}$ in broadband mode, with a data reduction of $97 \%$. For $\mathrm{MS}^{2}$ experiments the isolation was performed at $1 \mathrm{~m} / \mathrm{z}$ window and collision induced dissociation experiments were carried out with collision energies of 15 and $20 \mathrm{~V}$. The data were processed with Bruker Compass Data Analysis software. For the molecular ions sub-ppm accuracy was achieved, while for the collision induced dissociation experiments the detected fragment mass accuracy was below 10 ppm. Molecular structures were proposed based on the mass spectrometry fragmentation patterns, expected photochemical reactions and existing literature data.

Pseudo-first order apparent constant of ENR degradation ( $\mathrm{k}_{\mathrm{ENR}}$ ) was determined from the slope of $\ln \left(\mathrm{C}_{t} / \mathrm{C}_{0}\right)$ vs irradiation time $(\mathrm{t})$ where $\mathrm{C}_{0}$ was the initial ENR concentration and $\mathrm{C}_{\mathrm{t}}$ the remaining concentration at time t. $\mathrm{k}_{\mathrm{ENR}}$ were calculated from the fitting within 0-120 min, except in some cases where it was only considered with the first 30 min irradiation (ENR alone at $\mathrm{pH} 3.0$ aerated, $\mathrm{pH} 7.0$ aerated, $\mathrm{pH} 7.0$ de-aerated and $\mathrm{pH} 7.0$ oxygen saturated) due to deviation of the linear tendency at longer periods of time attributed to the competition effect of photogenerated products in solution. The emission spectrum of the lamp was recorded using a charge-coupled device (CCD) spectrophotometer (Ocean Optics USD 2000CUV-VIS) 
equipped with an optical fibre. Over the wavelength range of $260-600 \mathrm{~nm}$, a total photon flux of $157 \mathrm{~W} \mathrm{~m}^{-2}$ was determined.

The determination of the second-order rate constants between triplet ENR excited state $\left({ }^{3} \mathrm{ENR}^{*}\right)$ and ground state oxygen $\left({ }^{3} \mathrm{O}_{2}\right)$ was carried out with the nanosecond laser flash photolysis apparatus from Applied Photophysics-LKS60. The equipment and procedure employed for transition absorption experiments using laser flash photolysis system, has been previously described [161,162].

Error bars were calculated as the standard deviation between replicates, except for kinetic rate constant calculation, where they were obtained from the deviation from linear fit and experimental data (average between replicates).

\subsubsection{Fe-ENR complex characterization.}

The complex formation between $\mathrm{Fe}(\mathrm{III})$ and ENR was studied by analysing its stoichiometry and pH-stability. Fe-ENR stoichiometry was obtained by applying the method of continuous variation [163], acquiring the UV-vis spectra of fixed $100 \mu \mathrm{M} \mathrm{Fe}$ (III) solution at pH 3.0 with different ENR concentrations in the range 100 to $600 \mu \mathrm{M}$. For pH-stability analysis, the complex between ENR and Fe(III) was firstly prepared at $\mathrm{pH} 3.0$, and afterwards, $\mathrm{pH}$ was increased until the desired value and leaving each solution for $10 \mathrm{~h}$ in the dark with magnetic stirring.

\subsubsection{Irradiations}

Photochemical experiments were carried out in a thermostat cylindrical open glass reactor (total volume of $50 \mathrm{~mL}$ ) at $20^{\circ} \mathrm{C}$ loaded with $25 \mathrm{~mL}$ of the testing solution containing ENR $300 \mu \mathrm{M}$, with and without Fe(III) $100 \mu \mathrm{M}$. Irradiations were performed with a solar simulator (Lot-Oriel LS0306) equipped with a high-pressure Xe short arc lamp (Ushio UXL302-O) and a Pyrex filter to avoid wavelengths < $290 \mathrm{~nm}$. Iron-ENR complex solutions were always prepared and left with stirring for at least $10 \mathrm{~h}$ to assure full complexation prior to irradiation experiments. All assays were performed for $2 \mathrm{~h}$, withdrawing $1 \mathrm{~mL}$ of sample in time-intervals and filtered with PTFE $0.45 \mu \mathrm{m}$ Chromafil Xtra filters. When needed, $200 \mu \mathrm{M}$ $\mathrm{H}_{2} \mathrm{O}_{2}$ were employed as source of ${ }^{\bullet} \mathrm{OH}$. Two initial $\mathrm{pH}$ were studied, 3.0 where Fenton-(like) processes are optimal, and 7.0, relevant towards realistic natural/wastewater scenario. All samples $(1 \mathrm{~mL})$ were filtered with PTFE $0.45 \mu \mathrm{m}$ filters and mixed with $100 \mu \mathrm{L}$ of methanol in order to stop the reaction before analysis (i.e. to quench possible hydroxyl radical formation through Fenton reaction). Experiments were performed at least twice. 
The oxygen effect was studied by bubbling solution with pure $\mathrm{N}_{2}$ and $\mathrm{O}_{2}$ for $10 \mathrm{~min}$ before and during the photochemical experiment, thus assuring negligible and high $\mathrm{O}_{2}$ concentrations, respectively. Formation of reactive oxygen species (ROS) was studied employing isopropyl alcohol (IPA) $\left({ }^{\bullet} \mathrm{OH}\right.$ scavenger, $\left.\mathrm{k}^{\bullet} \mathrm{OH}=1.9 \times 10^{9} \mathrm{M}^{-1} \mathrm{~s}^{-1}\right)$ and furfuryl alcohol (FFA) $\left({ }^{\bullet} \mathrm{OH}\right.$ and ${ }^{1} \mathrm{O}_{2}$ scavenger, $\mathrm{k}^{\circ} \mathrm{OH}=1.5 \times 10^{10} \mathrm{M}^{-1} \mathrm{~s}^{-1}$ and $\mathrm{k}^{\prime} \mathrm{O}_{2}=1.2 \times 10^{8} \mathrm{M}^{-1} \mathrm{~s}^{-1}$, respectively) [62,164]. IPA was employed in a concentration of $5 \mathrm{mM}$ whereas FFA of 300 $\mu \mathrm{M}$. The chosen concentrations were based on other related works [45,165,166], ROS being able to react much faster with the probes than with ENR at $300 \mu \mathrm{M}$. It is important to highlight that FFA was chosen over $\mathrm{NaN}_{3}$ as ${ }^{1} \mathrm{O}_{2}$ probe since this last one is highly $\mathrm{pH}$ dependent $\left(\mathrm{k}^{1} \mathrm{O}_{2}\left(\mathrm{~N}_{3}{ }^{-}\right.\right.$ ) $=5 \times 10^{8} \mathrm{M}^{-1} \mathrm{~s}^{-1}$ and $\mathrm{k}^{1} \mathrm{O}_{2}\left(\mathrm{HN}_{3}\right) \approx 10^{6} \mathrm{M}^{-1} \mathrm{~s}^{-1}$, with $\mathrm{pKa}=4.6$, being also $\mathrm{HN}_{3}$ strongly partitioned to the gas phase) [167], whereas FFA is not [168], thus being better when comparing assays at $\mathrm{pH} 3.0$ with $\mathrm{pH} 7.0$.

\subsubsection{Results and discussion}

\subsubsection{Complexation with ferric ions}

When iron(III) perchlorate is added to an ENR solution (both colourless) at pH 3.0, the mixture changed into a yellow-colour solution. Indeed, an absorbance shoulder after $400 \mathrm{~nm}$ and up to $540 \mathrm{~nm}$ appears in the UV-vis spectrum of ENR-iron mixture (Figure 4.1A). Such absorption suggests that a charge-transfer transition between the ENR and Fe(III) occurs, corresponding to the formation of a coordination complex [152]. In Figure 4.1B, the absorbance at $430 \mathrm{~nm}$ as a function of different ENR/Fe(III) ratios is depicted. Absorbance increases from 0.23 to about 0.43 when $\mathrm{ENR} / \mathrm{Fe}$ (III) ratio grows up to 3, and then reaches a plateau at higher ratios. Such finding is in agreement with an octahedral complex employing the FQ carbonyl and carboxyl moieties to bind Fe(III) with a ratio 3:1, which has been previously reported [169]. Then, the ENR-iron complex $\left(\mathrm{Fe}^{\mathrm{III}}-\mathrm{ENR}_{3}\right)$ stability was investigated in the range of $\mathrm{pH} 3.0$ to 9.0 with measuring the total iron concentration in solution.

In addition, $\mathrm{Fe}^{\mathrm{III}}-\mathrm{ENR}_{3}$ solutions from $\mathrm{pH} 3.0$ to 7.5 proved to be stable at least for one month in the dark and at room temperature since Fe(III) remained in solution all time. In fact, the formation constant of $\mathrm{Fe}^{\mathrm{III}}-\mathrm{ENR}_{3}$ complex is reported to have its highest value at acidic $\mathrm{pH}$, $\log \mathrm{K}\left(\mathrm{Fe}^{\mathrm{III}}-\mathrm{ENR}_{3}\right) \approx 45$, and it decreases with increasing $\mathrm{pH}$, being equal to 25 at neutral conditions [169]. These values are comparable with other stable Fe(III)-organic ligand complexes such as ethylenediaminetetraacetic acid (EDTA) $\left(\operatorname{logK}\left(\mathrm{Fe}^{\mathrm{III}}\right.\right.$-EDTA $\left.) \approx 25\right)$ [170]. 
Preparation of analogous solutions containing Fe(II) instead of Fe(III) did not evidence the complex signal at $430 \mathrm{~nm}$, thus indicating that the ENR-ferrous complex is not formed [171].
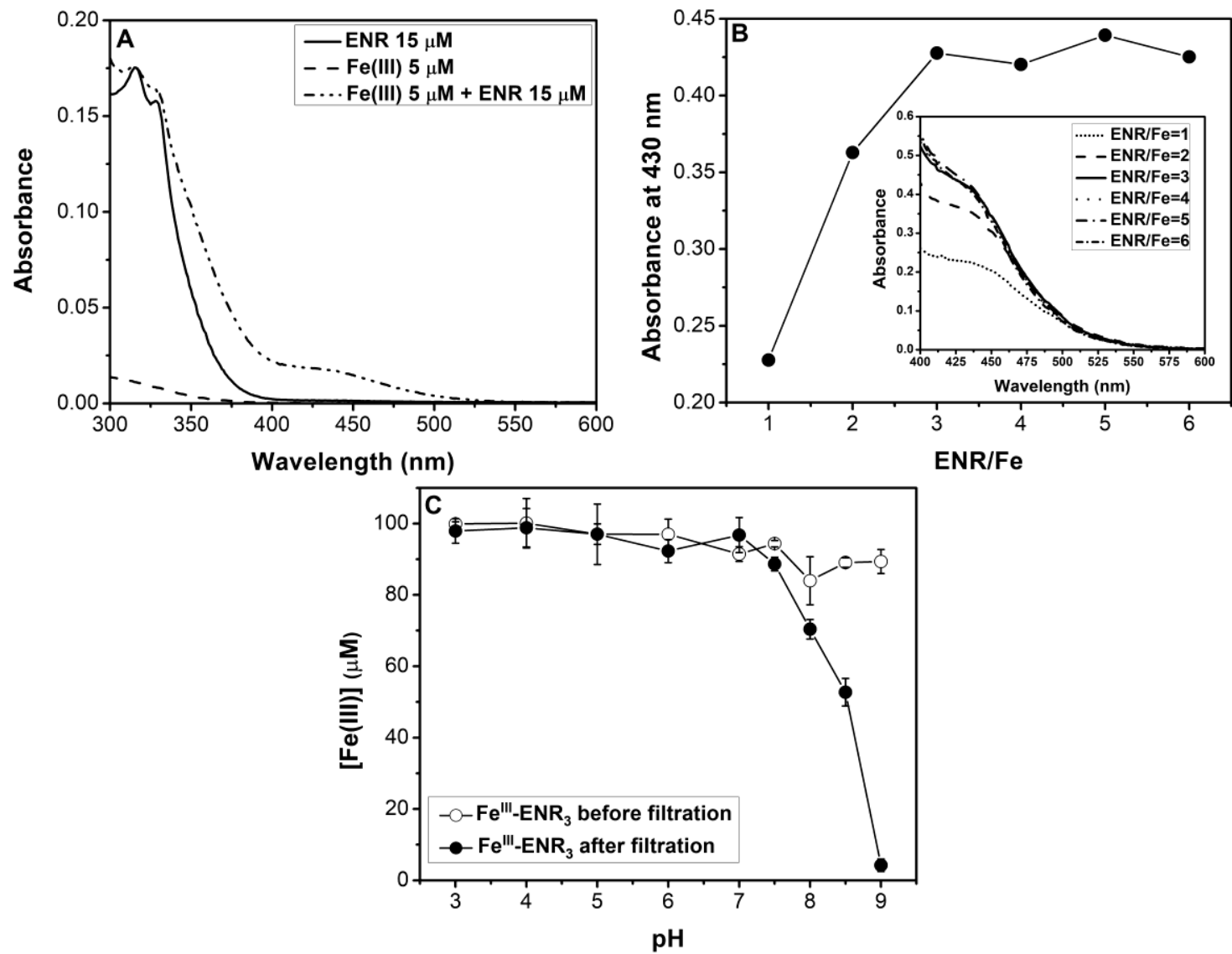

Figure 4.1. (A) Absorption spectra for ENR, Fe(III) and $\mathrm{Fe}^{\mathrm{III}}$-ENR 3 at $\mathrm{pH} \mathrm{3.0}$; (B) Method of continuous variation for a fixed amount of $\mathrm{Fe}(\mathrm{III}) 100 \mu \mathrm{M}$ and variating ENR concentration from 100 to $600 \mu \mathrm{M}$.

Insert represent the UV-vis spectra of different ENR/Fe(III) ratio solutions at pH 3.0. (C) Fe(III) concentration from $100 \mu \mathrm{M} \mathrm{Fe}^{\mathrm{III}}$-ENR 3 complex at different $\mathrm{pH}$ values measured $24 \mathrm{~h}$ after preparation. PTFE filters $0.45 \mu \mathrm{m}$ were used to filter solutions. Values represent the average of two measurements, and the error bar gives the associated uncertainty [118].

\subsubsection{Photodegradation experiments}

\subsection{Effect of $\mathrm{pH}$}

In order to investigate the degradation of the antibiotic, in free form or as iron-complex, the same concentration of ENR was considered for all the experiments $(300 \mu \mathrm{M}$ of ENR or 100 $\mu \mathrm{M}$ of $\mathrm{Fe}^{\mathrm{III}}-\mathrm{ENR}_{3}$ ) in acidic ( $\mathrm{pH}$ 3.0) and neutral ( $\mathrm{pH}$ 7.0) solutions. In this way, even though the pollutant concentration was higher than the environmental related levels, these allowed us to also study the $\mathrm{Fe}(\mathrm{III}) / \mathrm{Fe}$ (II) behaviour (see later Figure 4.7 and Figure 4.8B-D). In addition, the concentrations of the complex $\mathrm{Fe}^{\mathrm{III}}-\mathrm{ENR}_{3}$ between 1 and $100 \mathrm{mg} \mathrm{L}^{-1}$ has no effect on the photochemical process. Besides, some studies propose the use of photo-Fenton to treat the 
concentrate stream from membrane processes, hence, dealing with higher concentration of pollutants [172,173].

As shown in Figure 4.2, under irradiation at $\mathrm{pH}$ 3.0, the pseudo-first order photolysis rate constants of ENR and as iron-complex were $3.7 \times 10^{-3}$ and $2.0 \times 10^{-3} \mathrm{~min}^{-1}$, respectively. Therefore, even though $\mathrm{Fe}^{\mathrm{III}}-\mathrm{ENR}_{3}$ exhibited greater absorbance within the visible region, we can assume that this complex could present higher activation energy for most of the photodegradation pathways of ENR, hence, being more stable against light irradiation than the pollutant alone, as it has been reported for other FQ-metal complexes [155,157]. At pH 7.0, where the zwitterionic form of ENR becomes predominant $\left(\mathrm{pKa}_{1} \approx 6.0\right.$ and $\mathrm{pKa}_{2} \approx 8.5$, Figure 4.3), the photolysis rate constant was one order of magnitude higher than at acidic conditions $\left(\mathrm{k}_{\mathrm{ENR}}=3.1 \times 10^{-2} \mathrm{~min}^{-1}\right)$, which is in agreement with the higher photolysis quantum yields of FQs for zwitterionic forms associated to changes in functional groups reactivity with the ionic forms [174]. After $2 \mathrm{~h}$ of irradiation, the $\mathrm{pH}$ decreased to 6.0 in agreement with decarboxylation of the molecule as confirmed by mass spectrometry analysis (section 4.1.3.4). Interestingly, in the case of iron-complex, the photolysis enhancement was clearly less marked than for free antibiotic, being its kinetic rate constant $5.3 \times 10^{-3} \mathrm{~min}^{-1}$, only 2.7 times more than at $\mathrm{pH}$ 3.0.

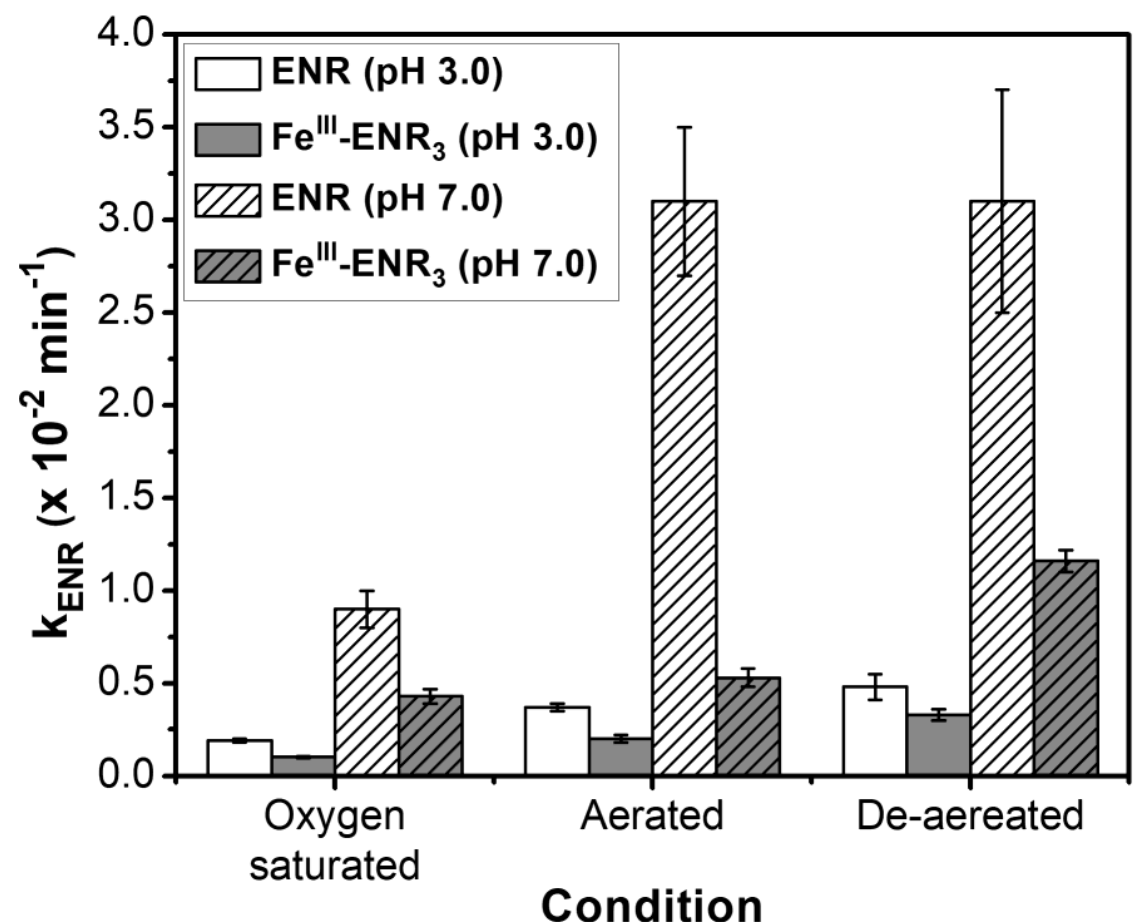

Figure 4.2. Photolytic rate constants for $\mathrm{ENR} 300 \mu \mathrm{M}$ and $\mathrm{Fe}^{\mathrm{III}}-\mathrm{ENR}_{3} 100 \mu \mathrm{M}$ at all tested conditions (error bars were calculated from the deviation from linear fit and experimental data) [118]. 
It is important to highlight that photolysis results at $\mathrm{pH} 3.0$ could had also been well explained by zero order fitting (see Figure 4.4A-B). However, this is opposed to the consensus of photolytic pseudo-first order kinetic fitting for FQs in all previously cited related works employing ca. $5 \mu \mathrm{M}$ [45], $120 \mu \mathrm{M}$ [71] or even $2.78 \times 10^{3} \mu \mathrm{M}$ [160].
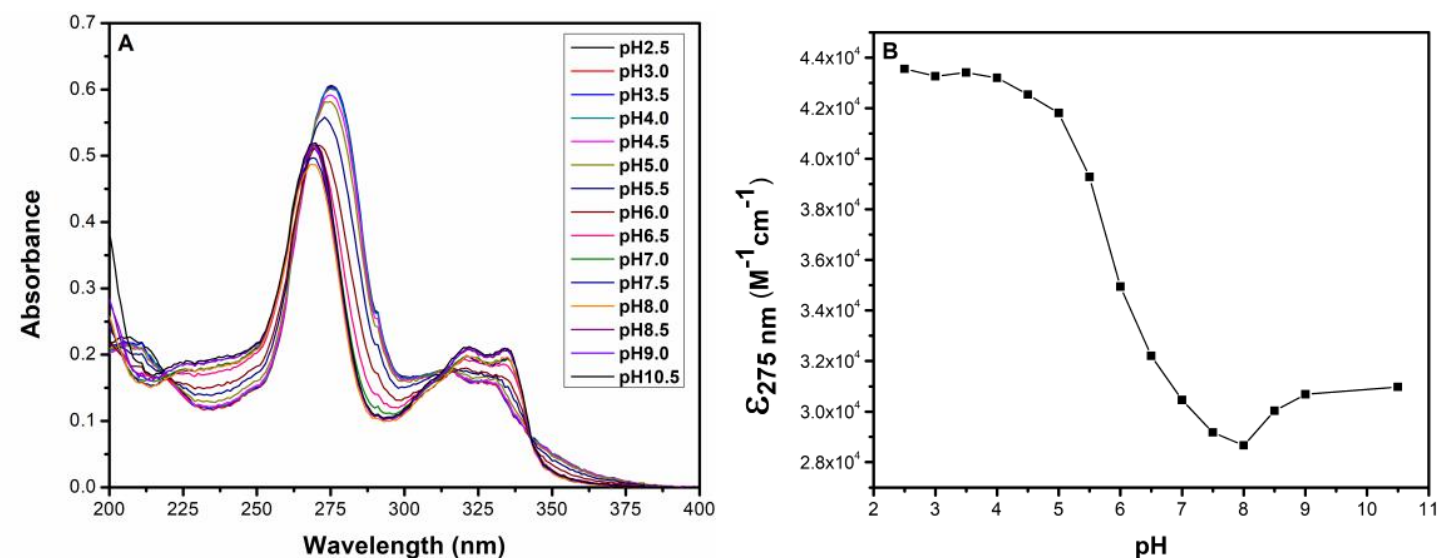

Figure 4.3. ENR pKa determination $([\mathrm{ENR}]=15 \mu \mathrm{M})$. A) Different spectra as function of $\mathrm{pH}(\mathrm{pH} 2.5$ to 10.5), B) Molar absorption coefficient ( $\varepsilon$ ) at $275 \mathrm{~nm}$ as function of $\mathrm{pH}$ [118].
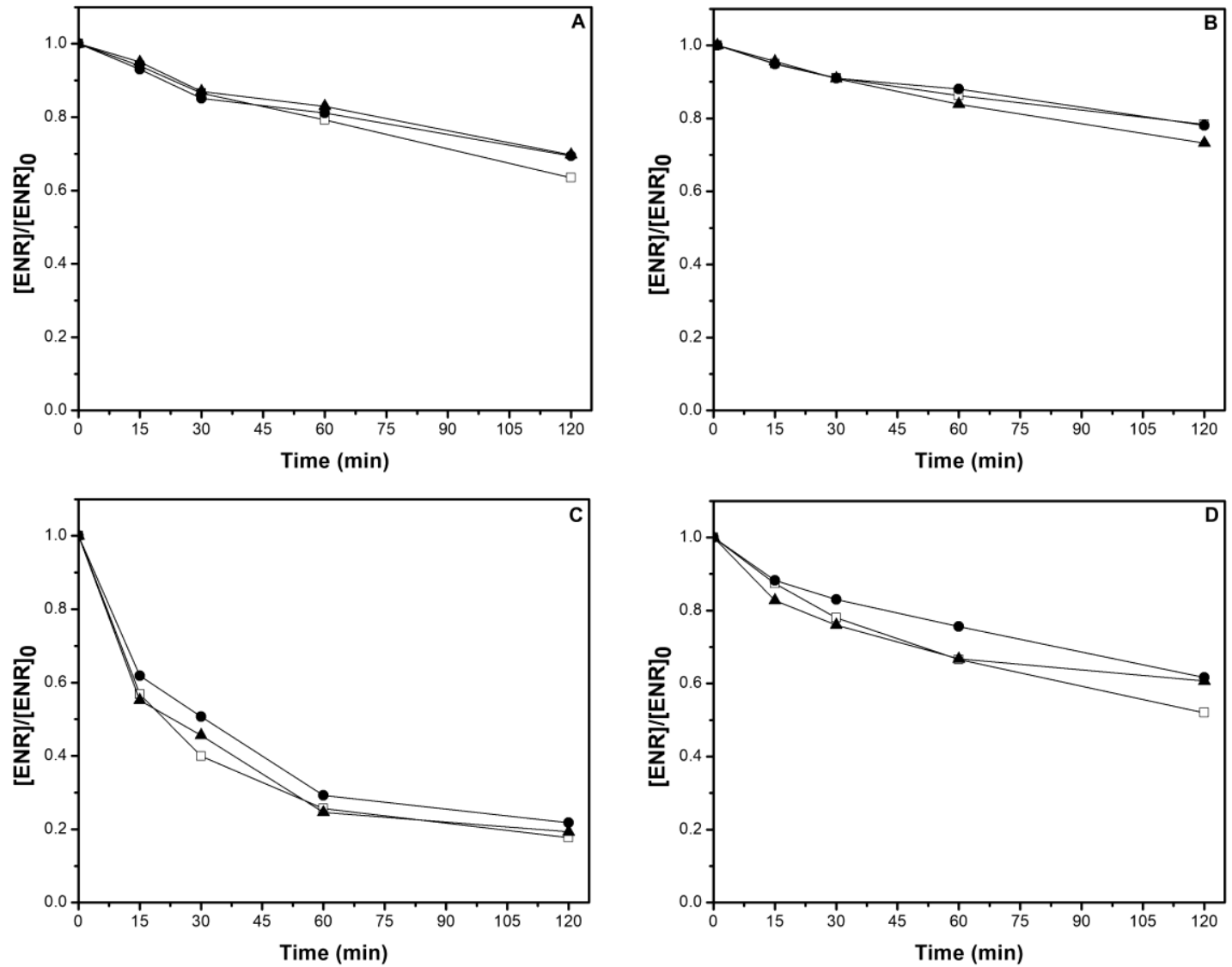

Figure 4.4. Effect of ROS scavenger addition (IPA $5 \mathrm{mM}$ and FFA $300 \mu \mathrm{M}$ ) at aerated conditions. ENR degradation without scavenger addition ( $\square$ ), with IPA $(\bullet)$ and with FFA $(\triangle)$ ). A) ENR $300 \mu M$ pH 3.0; B) $\mathrm{Fe}^{\mathrm{III}}$-ENR3 $100 \mu \mathrm{M}$ pH 3.0; C) ENR $300 \mu \mathrm{M}$ pH 7.0; D) Fe $\mathrm{III}^{\mathrm{III}} \mathrm{ENR} 3100 \mu \mathrm{M}$ pH 7.0 [118]. 


\subsection{ROS generation and effect of dissolved oxygen}

In order to understand the degradation mechanisms, different photochemical experiments were performed in the presence of ROS scavengers, such as IPA and FFA, or in oxygen saturated and de-aerated solutions. As shown in Figure 4.4, the presence of IPA (5 mM) and FFA $(300 \mu \mathrm{M})$ do not significantly modify the degradation of ENR or $\mathrm{Fe}^{\mathrm{III}}$-ENR $\mathrm{EN}_{3}$, indicating that generation of ${ }^{\bullet} \mathrm{OH}$ or ${ }^{1} \mathrm{O}_{2}$ by the self-sensitization process should not be relevant for ENR degradation in any of the studied cases. However, ${ }^{1} \mathrm{O}_{2}$ generation was confirmed when observing FFA degradation (Figure 4.5). At both studied pH, a 40\% FFA removal was obtained after 120 min with ENR, whereas for $\mathrm{Fe}^{\mathrm{III}}-\mathrm{ENR}_{3}, 10 \%$ and $25 \%$ was obtained at $\mathrm{pH}$ values 3.0 and 7.0, respectively. Therefore, ${ }^{1} \mathrm{O}_{2}$ formation should be reduced when ENR is chelating $\mathrm{Fe}(\mathrm{III})$, which is in agreement with other FQ-metal complexes that showed a decrease in singlet oxygen overall production [44]. Nevertheless, this could be also linked to the slower photolysis degradation in the case of the complex, resulting also in a lower singlet oxygen production. Therefore, we can conclude that Fe(III) complexation by ENR should affect more its direct photolysis pathways rather than its photosensitized ones.

Although singlet oxygen is formed through the interaction of dissolved oxygen $\left({ }^{3} \mathrm{O}_{2}\right)$ with the excited states of other molecules [175], ENR photodegradation was slower when increasing the amount of dissolved oxygen in the system. For instance, at $\mathrm{pH}=3.0$ and with the antibiotic alone, a photolytic rate constant of $4.8 \times 10^{-3} \mathrm{~min}^{-1}$ was determined under de-aerated conditions, whereas with an oxygen-saturated solution was $1.9 \times 10^{-3} \mathrm{~min}^{-1}$ (Figure 4.2). In line with these observations, faster quenching of ENR triplet state (ENR*) was obtained when increasing the dissolved oxygen concentration. Therefore, even though ENR could be oxidized by photogenerated ${ }^{1} \mathrm{O}_{2}$, the reactivity between them is estimated to be around $10^{6} \mathrm{M}^{-1} \mathrm{~s}^{-1}$ [44], which is considerably lower than the ${ }^{3} \mathrm{O}_{2}$ quenching by ENR* ${ }^{*}$, determined to be 4.7 and $3.7 \times$ $10^{9} \mathrm{M}^{-1} \mathrm{~s}^{-1}$ at $\mathrm{pH} 3$ and 7 (Figure 4.6A-B, respectively). For Fe ${ }^{\mathrm{III}}-\mathrm{ENR}_{3}$, the same counterproductive effect of ground state dissolved oxygen was observed, with the difference that the obtained removals were proportionally slower than the antibiotic in free form, in agreement with the higher photochemical stability of the FQ-metal complex.

At pH 7.0, dissolved oxygen inhibitory effect for ENR was observed when comparing aerated/de-aerated conditions ( $\mathrm{k}_{\mathrm{ENR}}=3.1 \times 10^{-2} \mathrm{~min}^{-1}$ in both cases) against oxygen-saturated ones $\left(\mathrm{k}_{\mathrm{ENR}}=9 \times 10^{-3} \mathrm{~min}^{-1}\right)$. On the contrary, for $\mathrm{Fe}^{\mathrm{III}}-\mathrm{ENR}_{3}$, the tendency remained as at acidic 
conditions, observing decreasing photolytic rate constants when going from de-aerated towards aerated, and oxygen saturated conditions (Figure 4.2).

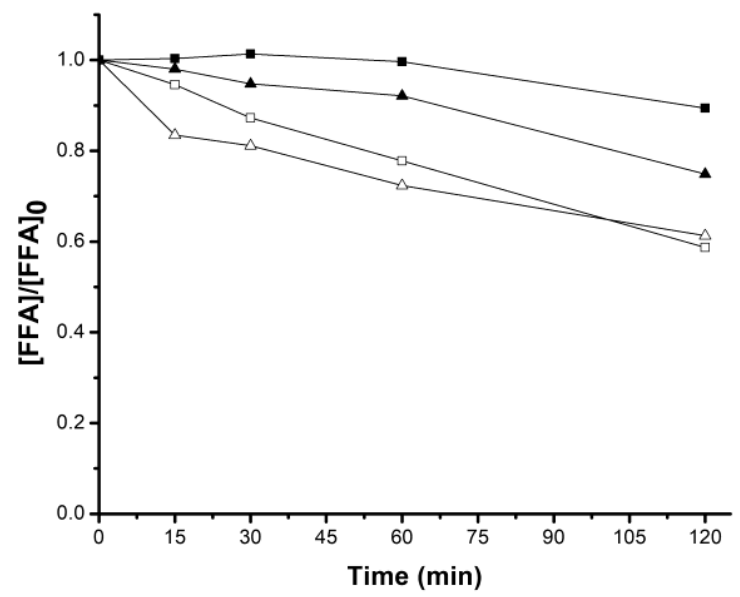

Figure 4.5. FFA $300 \mu \mathrm{M}$ removal by ${ }^{1} \mathrm{O}_{2}$ generation at different tested conditions: ENR $300 \mu \mathrm{M}$ pH 3.0 (口), FeIII-ENR3 $100 \mu \mathrm{M}$ pH $3.0(\square)$, ENR $300 \mu \mathrm{M}$ pH 7.0 ( $\triangle$ ), FeIII-ENR3 $100 \mu \mathrm{M}$ pH 7.0 ( $\triangle$ ). Control: FFA photodegradation alone at both studied $\mathrm{pH}$ was negligible (1-3\% in $120 \mathrm{~min})$ [118].
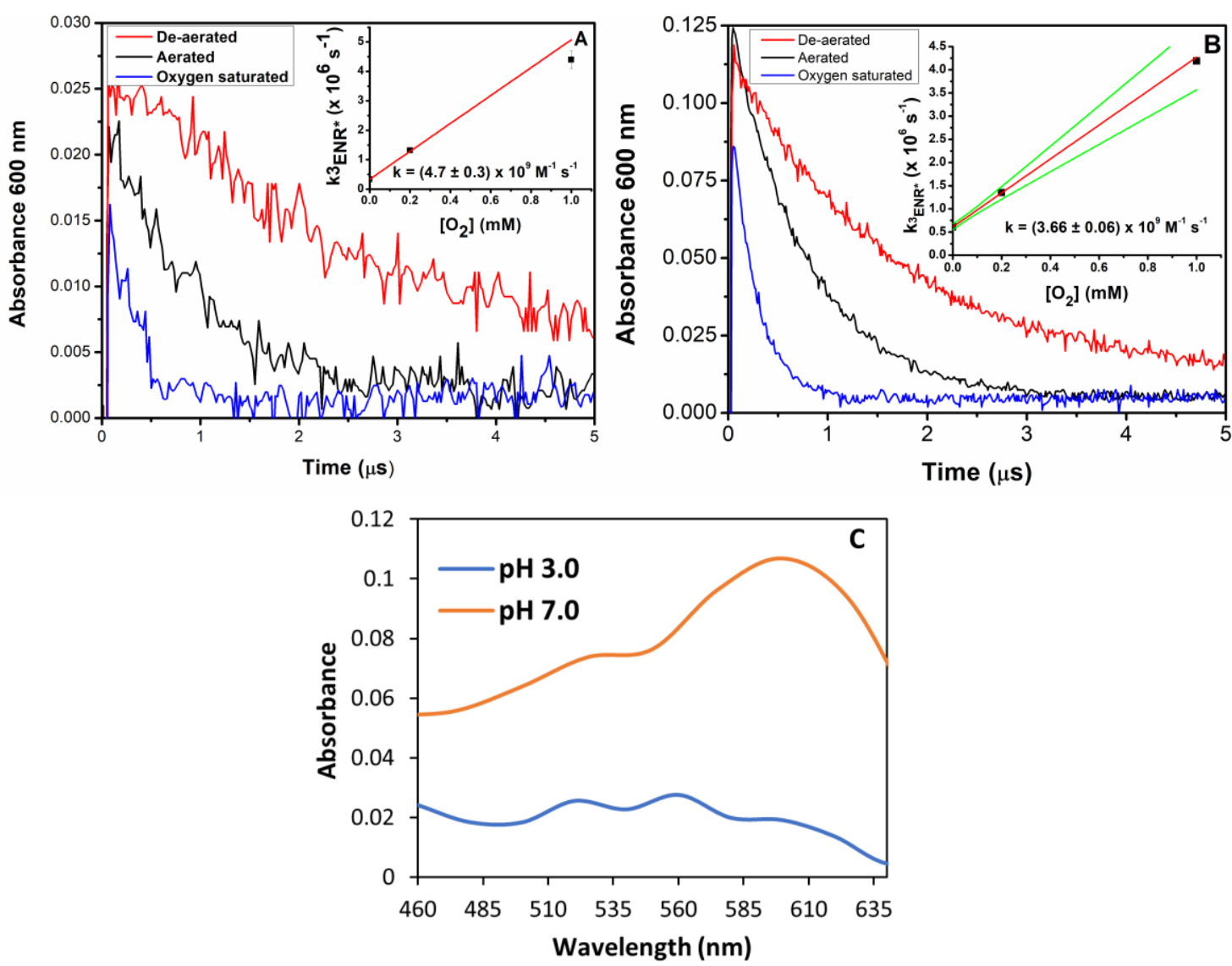

Figure 4.6 ENR $280 \mu \mathrm{M}$ laser flash photolysis measurements: A) and B) ${ }^{3} \mathrm{ENR}^{*}$ relaxation kinetics at pH 3.0 and 7.0, respectively, at de-aerated, aerated and oxygen saturated conditions, with ${ }^{3} \mathrm{O}_{2}$ quenching kinetic rate constant determination (inserted graph); C) ${ }^{3} \mathrm{ENR}^{*}$ absorbance spectra at both studied $\mathbf{p H}$ (measured at $0.09 \mu \mathrm{s})$ [118].

$\mathrm{Fe}$ (II) formation due to ligand to metal charge transfer (LMCT) within the photolysis of $\mathrm{Fe}^{\mathrm{III}}-\mathrm{ENR}_{3}$ at $\mathrm{pH} 3.0$, followed the same tendency, de-aerated $>$ aerated $>$ oxygen saturated 
(Figure 4.7), obtaining after $60 \mathrm{~min}$ irradiation, a reduction of $100 \%$ from $\mathrm{Fe}(\mathrm{III})$ to $\mathrm{Fe}(\mathrm{II})$ with $\mathrm{N}_{2}$ bubbling, $87 \%$ in aerated conditions, and $36 \%$ with $\mathrm{O}_{2}$ bubbling.

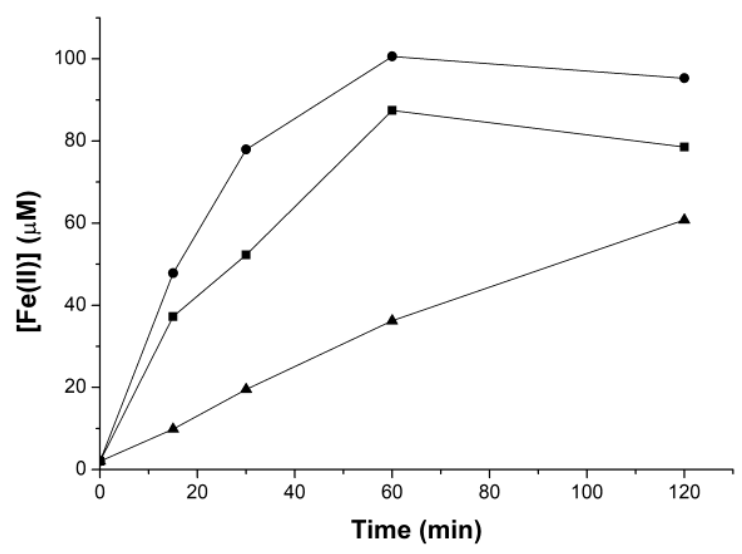

Figure 4.7. $\mathrm{Fe}(\mathrm{II})$ formation from $\mathrm{Fe}^{\mathrm{III}}$-ENR3 $\left([\mathrm{Fe}(\mathrm{III})]_{0}=100 \mu \mathrm{M},[\mathrm{ENR}]_{0}=300 \mu \mathrm{M}\right)$ at $\mathrm{pH} 3.0$ under irradiations in de-aerated $(\bullet)$, aerated $(\bullet)$ and oxygen saturated conditions $(\triangle)$ [118].

Based on these results, a plausible reaction mechanism can be proposed as following: after absorption of light, an electron of ENR can be promoted to the excited state $\left({ }^{1} \mathrm{ENR} *\right)$ followed by intersystem crossing and generation of ENR triplet state $\left({ }^{3} \mathrm{ENR}^{*}\right)(\mathrm{R} 4.1)$. The excited triplet state can lead to the formation of degradation product (R 4.2) or can be quenched by molecular oxygen $\left({ }^{3} \mathrm{O}_{2}\right)$ through energy transfer reaction leading to the formation of singlet oxygen $\left({ }^{1} \mathrm{O}_{2}\right)$ and ENR ground state $(\mathrm{R} 4.3)$. Photogenerated ${ }^{1} \mathrm{O}_{2}$ can also slightly contribute to the oxidation of ENR (R 4.4).

$\mathrm{ENR}+\mathrm{h} v \rightarrow{ }^{1} \mathrm{ENR}^{*} \rightarrow{ }^{3} \mathrm{ENR} *$

${ }^{3} \mathrm{ENR}^{*} \rightarrow$ ENR-ox

${ }^{3} \mathrm{ENR}^{*}+{ }^{3} \mathrm{O}_{2} \rightarrow{ }^{1} \mathrm{O}_{2}+\mathrm{ENR}$

$\mathrm{ENR}+{ }^{1} \mathrm{O}_{2} \rightarrow$ ENR-ox

For $\mathrm{Fe}^{\mathrm{III}}-\mathrm{ENR}_{3}$, the first photoinduced reaction is the LMCT reaction, leading to the formation of ferrous ions (Fe(II)), 2 molecules of ENR, and ENR radical (ENR $\bullet$ ) in solution (R 4.5). ENR $^{\bullet}$ can start different degradation pathways in which water and oxygen can be involved (R 4.6).

$\mathrm{Fe}^{\mathrm{III}}-\mathrm{ENR}_{3}+\mathrm{h} v \rightarrow \mathrm{Fe}(\mathrm{II})+2 \mathrm{ENR}+\mathrm{ENR}^{\bullet}$

$\mathrm{ENR}^{\bullet} \rightarrow \longrightarrow$ products

$\mathrm{R} 4.6$ 


\subsection{Time-course absorbance spectra changes}

Analysing the changes in absorbance spectra with light irradiation for ENR and $\mathrm{Fe}^{\mathrm{III}}$ $\mathrm{ENR}_{3}$ at $\mathrm{pH}$ 3.0, a signal formation at $535 \mathrm{~nm}$ was observed (Figure 4.8A-B), also evidenced by a final light pink colour of the solutions after the $120 \mathrm{~min}$ of irradiation, which could probably be related to the formation of poly-conjugated products [176]. Secondly, analysing the iron complex (Figure 4.8B) two additional issues have been seen: 1) there is a decay in 430 nm complex signal, which is related to the Fe(III) reduction to Fe(II) due to LMCT process, and 2) an isosbestic point at $516 \mathrm{~nm}$ was obtained, which suggests the conversion of $\mathrm{Fe}^{\mathrm{III}}-\mathrm{ENR}_{3}$ into one main absorbing photoproduct.

Analogous results for pH 7.0 are shown in Figure 4.8C-D, where pink colourization of the solution after irradiation was also observed, thus, with signal formation at $535 \mathrm{~nm}$ (however, not as pronounced as at acidic conditions). As expected, no complex absorbance signal decay was observed for $\mathrm{Fe}^{\mathrm{III}}-\mathrm{ENR}_{3}$ due to fast re-oxidation of $\mathrm{Fe}(\mathrm{II})$ at neutral $\mathrm{pH}$. In addition, there was only a negligible total iron loss within $\mathrm{Fe}^{\mathrm{III}}-\mathrm{ENR}_{3}$ irradiations at $\mathrm{pH} 7.0$ (5$10 \%$ after $2 \mathrm{~h}$ ), indicating that the by-product formation should be of the FQ-type structure, hence still being capable of binding iron and keeping it in aqueous solution even at neutral pH [137]. 

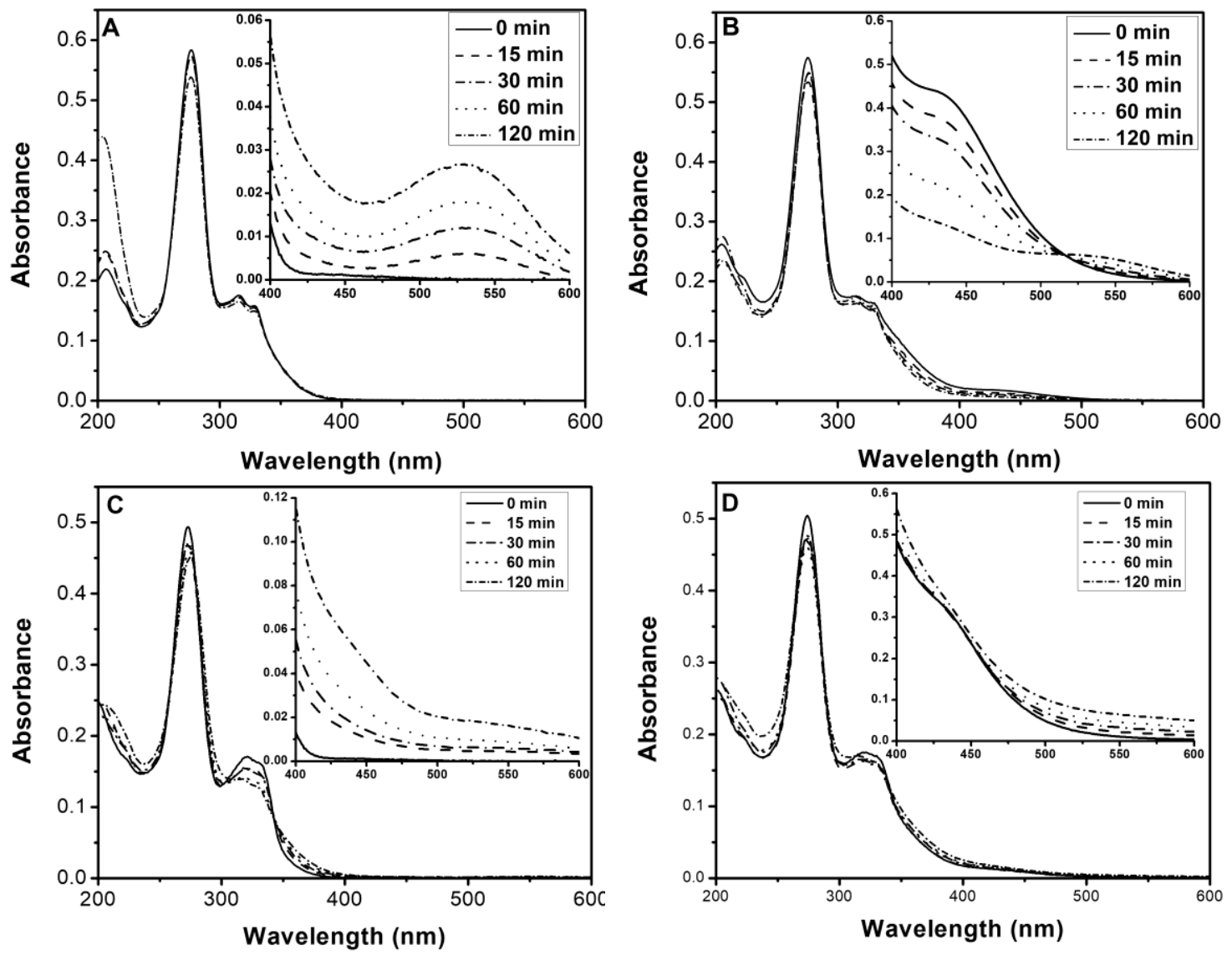

Figure 4.8. Time-course absorbance spectra changes during irradiation experiments at pH 3.0 and pH 7.0. Full spectra were recorded by 20 times dilution of the original sample (in the insert). (A) ENR 300 $\mu \mathrm{MH} 3.0$; (B) Fe $\mathrm{FII}_{-\mathrm{ENR}} 100 \mu \mathrm{M}$ pH 3.0; (C) ENR $300 \mu \mathrm{M}$ pH 7.0; (D) Fe $\mathrm{III}_{-\mathrm{ENR}} 100 \mu \mathrm{M}$ pH 7.0 [118].

\subsubsection{Impact of $\mathrm{H}_{2} \mathrm{O}_{2}$ addition}

In the frame of water treatment, the effect of $\mathrm{H}_{2} \mathrm{O}_{2}$ addition $(200 \mu \mathrm{M})$ was also studied. In this case, higher amounts of ${ }^{\circ} \mathrm{OH}$ are produced in situ due to $\mathrm{H}_{2} \mathrm{O}_{2}$ photolysis observed using the same irradiation setup ( $\mathrm{R}$ 1.8) [177] as well as Fenton-like and Fenton reactions (R 4.7 and $\mathrm{R}$ 4.8), strongly enhanced by the photo-generated $\mathrm{Fe}(\mathrm{II})$ in the presence of the complex $\mathrm{Fe}^{\mathrm{III}}$ $\mathrm{ENR}_{3}(\mathrm{R} 4.5)$ [61]. Due to this reason, under light at $\mathrm{pH}$ 3.0, $\mathrm{Fe}^{\mathrm{III}}-\mathrm{ENR}_{3}$ was even more reactive than ENR, obtaining $60 \%$ removal in $60 \mathrm{~min}$, compared to the $40 \%$ of the free antibiotic (Figure 4.9). By comparison to the photochemical system without $\mathrm{H}_{2} \mathrm{O}_{2}$, ENR removal effectiveness was increased by a factor of 2 , while for $\mathrm{Fe}^{\mathrm{III}}-\mathrm{ENR}_{3}$, this increment reached approximately a factor of 4 .

$$
\begin{aligned}
& \mathrm{Fe}^{\mathrm{III}}-\mathrm{ENR}_{3}+\mathrm{H}_{2} \mathrm{O}_{2} \rightarrow 3 \mathrm{ENR}+\mathrm{Fe}(\mathrm{II})+\mathrm{HO}_{2}^{\bullet}+\mathrm{H}^{+} \\
& \mathrm{Fe}(\mathrm{II})+\mathrm{H}_{2} \mathrm{O}_{2} \rightarrow \mathrm{Fe}(\mathrm{III})+\bullet{ }^{\bullet} \mathrm{OH}+\mathrm{OH}^{-} \\
& \bullet \mathrm{OH}+\mathrm{ENR} \rightarrow \text { ENR-ox }
\end{aligned}
$$


At pH 7.0 under light, even though the antibiotic removal was slightly higher without $\mathrm{Fe}(\mathrm{III})$ ( $74 \%$ for the free form, and 59\% for the iron complexed one in $60 \mathrm{~min}$ ), $\mathrm{H}_{2} \mathrm{O}_{2}$ did not enhance ENR degradation, thus, the contribution of the low concentration of photogenerated - $\mathrm{OH}$ from $\mathrm{H}_{2} \mathrm{O}_{2}$ photolysis was negligible for the already fast ENR photolytic degradation. On the contrary, the addition of $\mathrm{H}_{2} \mathrm{O}_{2}$ to the analogous system containing $\mathrm{Fe}(\mathrm{III})$, represented a removal increment for almost the double than the one without it. Therefore, it can be

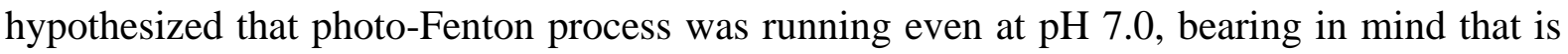
usually no longer effective in these conditions without the addition of any chelating agent due to the precipitation of iron oxides [82,90,93].

No significant differences were obtained for $\mathrm{Fe}^{\mathrm{III}}-\mathrm{ENR}_{3}$ under light and in the presence of $\mathrm{H}_{2} \mathrm{O}_{2}$ for the both studied $\mathrm{pH}$ values (c.a. $60 \%$ in $60 \mathrm{~min}$ in both cases). However, since photolytic degradation was lower at $\mathrm{pH} 3.0$ than at $\mathrm{pH} 7.0$ (14\% and 33\% in $60 \mathrm{~min}$, respectively), photo-Fenton contribution to the overall pollutant removal should have been lower at neutral conditions, as expected.

Within dark controls, the greater reactivity of $\mathrm{Fe}^{\mathrm{III}}-\mathrm{ENR}_{3}$ against $\mathrm{H}_{2} \mathrm{O}_{2}$ was even more evident. While for ENR no degradation was observed in any case, for the iron-complex form, $20 \%$ degradation was achieved at $\mathrm{pH} 3.0$, and $6 \%$ at $\mathrm{pH} 7.0$.

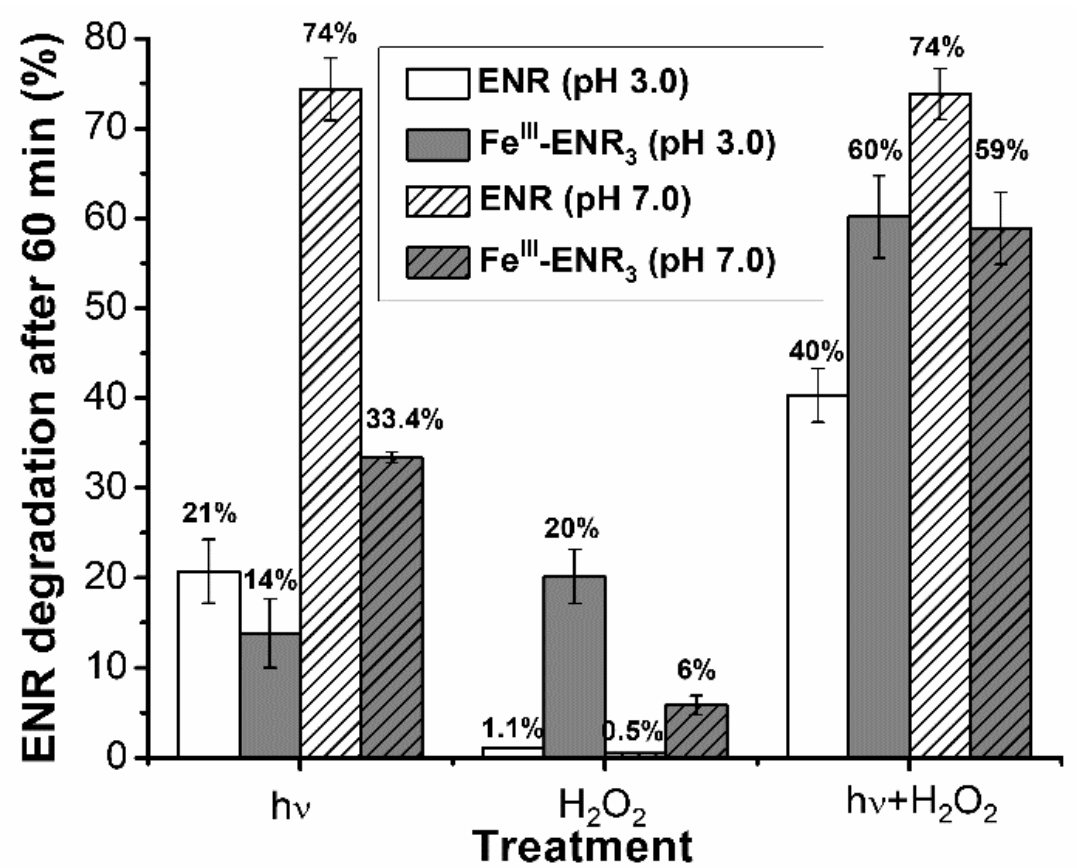

Figure 4.9. Degradation percentages after $60 \mathrm{~min}$ at both studied $\mathrm{pH}$ in aerated conditions, under sunlight irradiation (hv), with $\mathrm{H}_{2} \mathrm{O}_{2} 200 \mu \mathrm{M}$ without irradiation (dark control), and the combination of both, $h v+H_{2} \mathrm{O}_{2} 200 \mu \mathrm{M}$, for $300 \mu \mathrm{M}$ of ENR and $100 \mu \mathrm{M}$ of $\mathrm{Fe}^{\mathrm{III}}$-ENR3. Error bars were calculated as the associated standard deviation between respective duplicates [118]. 


\subsubsection{Photoproduct identification and formation pathways}

A total of 39 photoproducts were detected under the different reaction conditions, exact molecular formulas were determined for all of them, based on accurate mass measurements. The 14 most abundant ones were successfully isolated and fragmented to obtain structural information (Table 4.1), and a schematic degradation pathway was proposed (Figure 4.10). Results for the whole 39 photoproducts are shown in Figure 4.11.

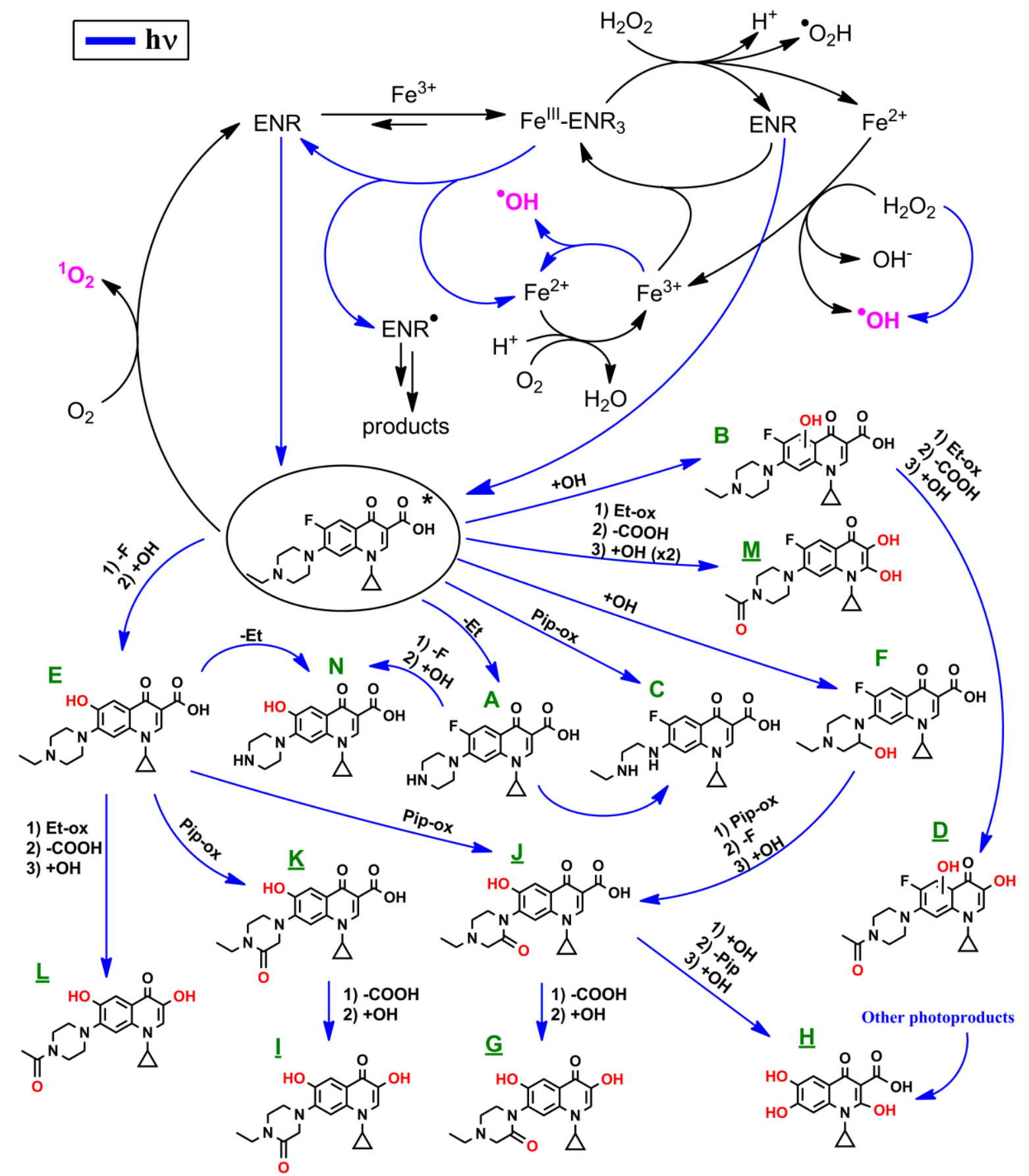

Figure 4.10. Summary of the studied reactions and photoproduct formation mechanism proposal.

Underlined photoproducts were found for the first time in this work. Reactions include defluorination (F), decarboxylation (-COOH), hydroxylation (+OH), piperazine cleavage and oxidation (-Pip and Pip-ox, respectively), and ethyl moiety cleavage and oxidation (-Et and Et-ox, respectively) [118]. 
Table 4.1. Elucidated major photoproducts in both systems ENR and Fe $\mathrm{FII}_{\text {-ENR }}$ and at both studied pHs. * indicated for those who were not found in bibliography [118].

\begin{tabular}{|c|c|c|c|c|c|c|c|}
\hline Name & $\begin{array}{l}\text { Ret. } \\
\text { Time } \\
\text { (min) }\end{array}$ & $\begin{array}{l}\mathrm{m} / \mathrm{z} \text { for } \\
{[\mathrm{M}+\mathrm{H}]^{+}}\end{array}$ & $\begin{array}{l}\text { Empirical } \\
\text { formula of the } \\
\text { neutral form }\end{array}$ & $\begin{array}{c}\text { Fragment } \\
\text { ion mass } \\
{[\mathrm{F}+\mathrm{H}]^{+}}\end{array}$ & $\begin{array}{l}\text { Raw formulas of } \\
\text { fragment ions }\end{array}$ & Elucidated structure & \\
\hline ENR & 7.0 & 360.17207 & $\mathrm{C}_{19} \mathrm{H}_{23} \mathrm{FN}_{3} \mathrm{O}_{3}$ & $\begin{array}{l}342.165 \\
316.184 \\
314.169 \\
245.110\end{array}$ & $\begin{array}{l}\mathrm{C}_{19} \mathrm{H}_{21} \mathrm{FN}_{3} \mathrm{O}_{2} \\
\mathrm{C}_{14} \mathrm{H}_{14} \mathrm{FN}_{2} \mathrm{O} \\
\mathrm{C}_{18} \mathrm{H}_{21} \mathrm{FN}_{3} \mathrm{O} \\
\mathrm{C}_{18} \mathrm{H}_{23} \mathrm{FN}_{3} \mathrm{O}\end{array}$ & & Literature data \\
\hline A & 6.8 & 332.14072 & $\mathrm{C}_{17} \mathrm{H}_{19} \mathrm{FN}_{3} \mathrm{O}_{3}$ & $\begin{array}{l}288.153 \\
268.147 \\
245.110\end{array}$ & $\begin{array}{l}\mathrm{C}_{16} \mathrm{H}_{19} \mathrm{FN}_{3} \mathrm{O} \\
\mathrm{C}_{16} \mathrm{H}_{18} \mathrm{~N}_{3} \mathrm{O} \\
\mathrm{C}_{14} \mathrm{H}_{14} \mathrm{FN}_{2} \mathrm{O}\end{array}$ & & {$[46,48,178,179]$} \\
\hline B & 7.0 & 376.16705 & $\mathrm{C}_{19} \mathrm{H}_{23} \mathrm{FN}_{3} \mathrm{O}_{4}$ & $\begin{array}{l}358.156 \\
332.180 \\
305.097 \\
301.125 \\
287.109 \\
261.106 \\
233.074\end{array}$ & $\begin{array}{l}\mathrm{C}_{19} \mathrm{H}_{21} \mathrm{FN}_{3} \mathrm{O}_{3} \\
\mathrm{C}_{18} \mathrm{H}_{23} \mathrm{FN}_{3} \mathrm{O}_{2} \\
\mathrm{C}_{15} \mathrm{H}_{14} \mathrm{FN}_{2} \mathrm{O}_{4} \\
\mathrm{C}_{16} \mathrm{H}_{16} \mathrm{FN}_{3} \mathrm{O}_{2} \\
\mathrm{C}_{15} \mathrm{H}_{14} \mathrm{FN}_{3} \mathrm{O}_{2} \\
\mathrm{C}_{14} \mathrm{H}_{14} \mathrm{FN}_{2} \mathrm{O}_{2} \\
\mathrm{C}_{12} \mathrm{H}_{10} \mathrm{FN}_{2} \mathrm{O}_{2}\end{array}$ & & Analogous $[45,180]$ \\
\hline
\end{tabular}




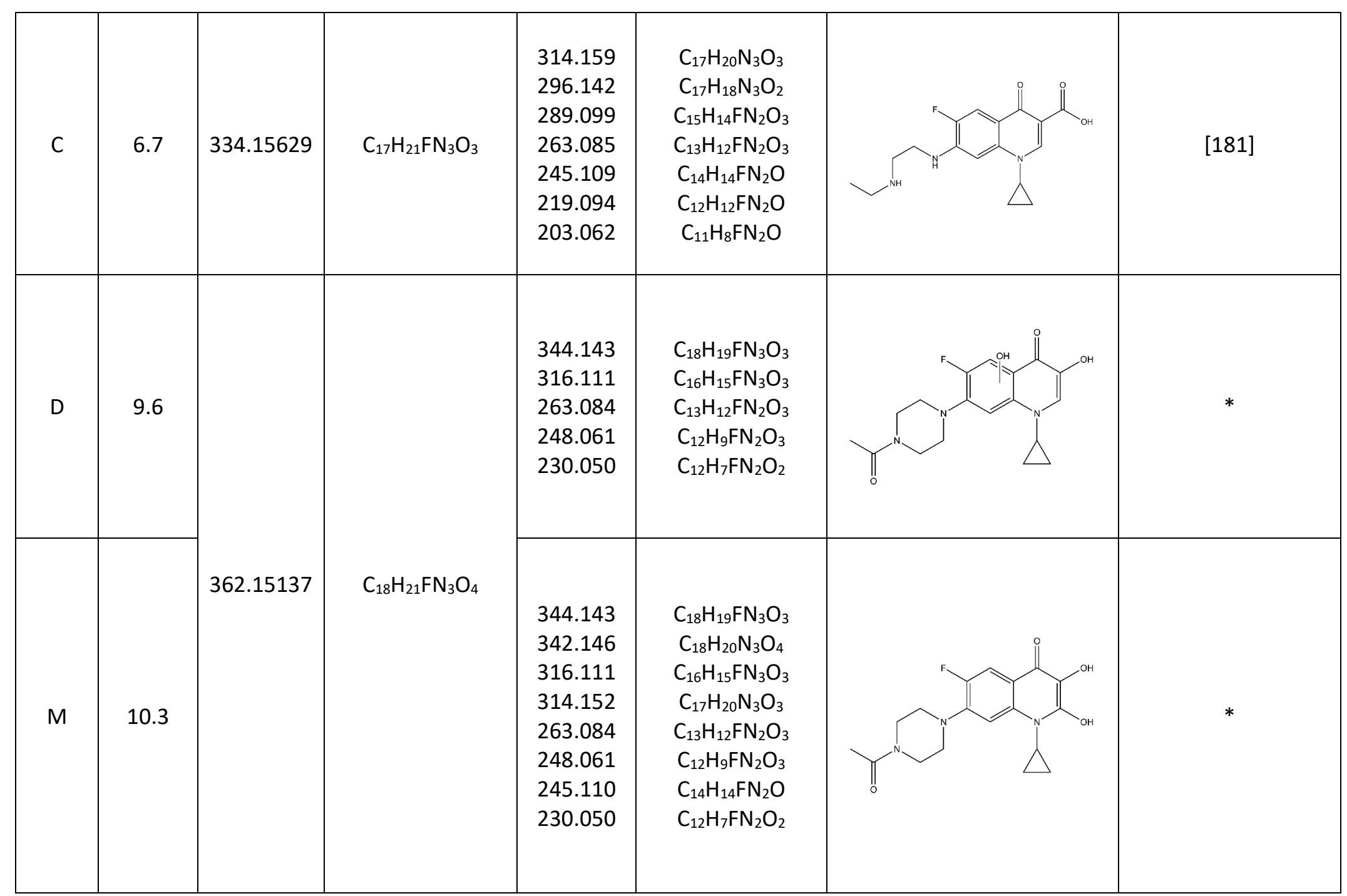




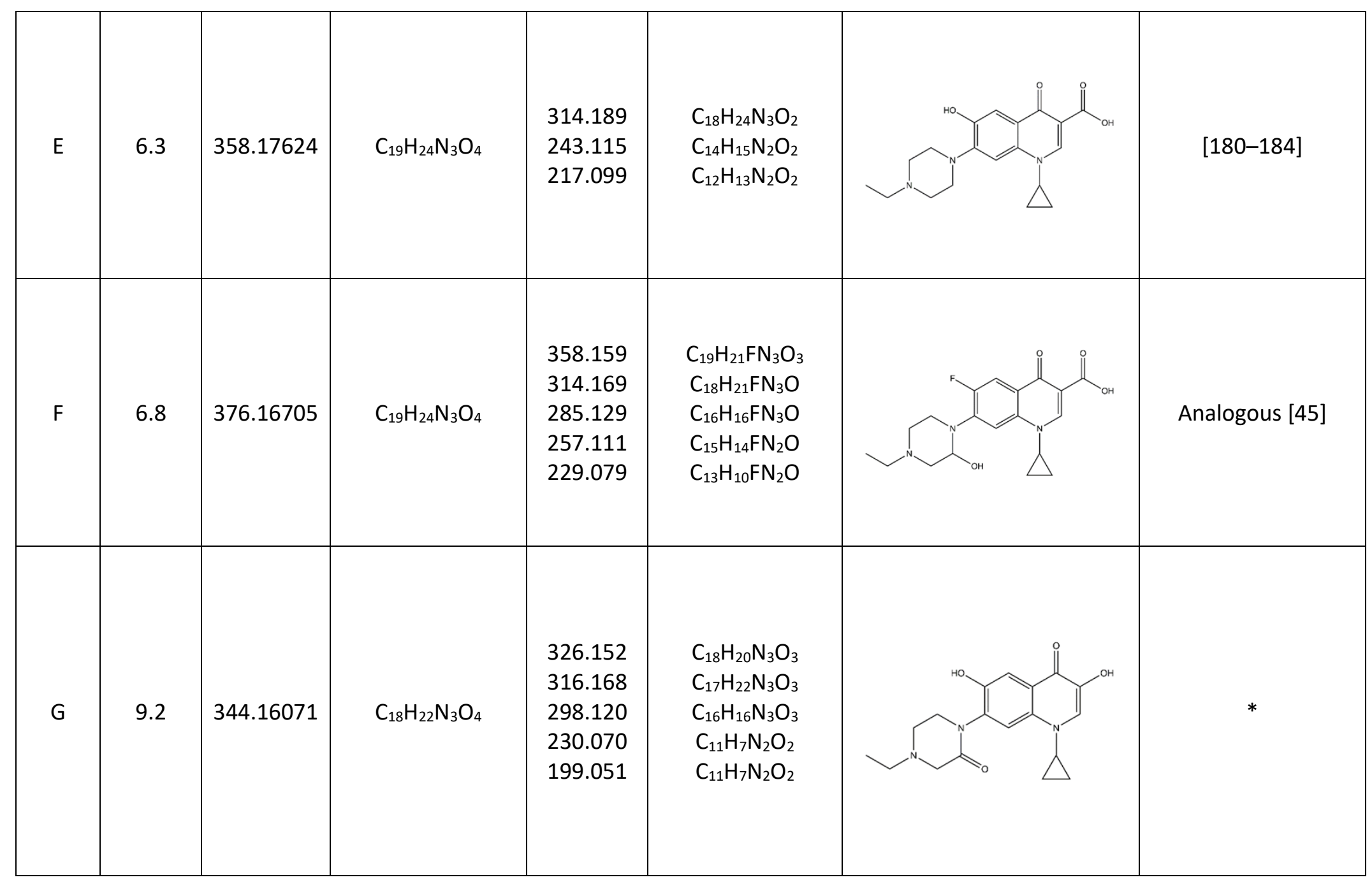




\begin{tabular}{|c|c|c|c|c|c|c|c|}
\hline I & 9.6 & & & $\begin{array}{l}326.152 \\
316.168 \\
298.120 \\
245.093 \\
230.070 \\
212.059 \\
199.051\end{array}$ & $\begin{array}{l}\mathrm{C}_{18} \mathrm{H}_{20} \mathrm{~N}_{3} \mathrm{O}_{3} \\
\mathrm{C}_{17} \mathrm{H}_{22} \mathrm{~N}_{3} \mathrm{O}_{3} \\
\mathrm{C}_{16} \mathrm{H}_{16} \mathrm{~N}_{3} \mathrm{O}_{3} \\
\mathrm{C}_{12} \mathrm{H}_{10} \mathrm{~N}_{2} \mathrm{O}_{3} \\
\mathrm{C}_{11} \mathrm{H}_{7} \mathrm{~N}_{2} \mathrm{O}_{2} \\
\mathrm{C}_{12} \mathrm{H}_{8} \mathrm{~N}_{2} \mathrm{O}_{2} \\
\mathrm{C}_{11} \mathrm{H}_{7} \mathrm{~N}_{2} \mathrm{O}_{2}\end{array}$ & & $*$ \\
\hline $\mathrm{H}$ & 8.7 & 278.06611 & $\mathrm{C}_{13} \mathrm{H}_{12} \mathrm{NO}_{6}$ & $\begin{array}{l}260.057 \\
237.029 \\
232.062 \\
219.018 \\
191.023\end{array}$ & $\begin{array}{c}\mathrm{C}_{13} \mathrm{H}_{10} \mathrm{NO}_{5} \\
\mathrm{C}_{10} \mathrm{H}_{7} \mathrm{NO}_{6} \\
\mathrm{C}_{12} \mathrm{H}_{10} \mathrm{NO}_{4} \\
\mathrm{C}_{10} \mathrm{H}_{5} \mathrm{NO}_{5} \\
\mathrm{C}_{9} \mathrm{H}_{5} \mathrm{NO}_{4}\end{array}$ & & $*$ \\
\hline J & 8.6 & 372.15576 & $\mathrm{C}_{19} \mathrm{H}_{22} \mathrm{~N}_{3} \mathrm{O}_{5}$ & $\begin{array}{l}344.163 \\
281.094 \\
273.089 \\
259.073 \\
241.062 \\
100.076\end{array}$ & $\begin{array}{c}\mathrm{C}_{18} \mathrm{H}_{22} \mathrm{~N}_{3} \mathrm{O}_{4} \\
\mathrm{C}_{16} \mathrm{H}_{13} \mathrm{~N}_{2} \mathrm{O}_{3} \\
\mathrm{C}_{14} \mathrm{H}_{13} \mathrm{~N}_{2} \mathrm{O}_{4} \\
\mathrm{C}_{13} \mathrm{H}_{11} \mathrm{~N}_{2} \mathrm{O}_{4} \\
\mathrm{C}_{13} \mathrm{H}_{9} \mathrm{~N}_{2} \mathrm{O}_{3} \\
\mathrm{C}_{5} \mathrm{H}_{10} \mathrm{NO}\end{array}$ & & $*$ \\
\hline
\end{tabular}




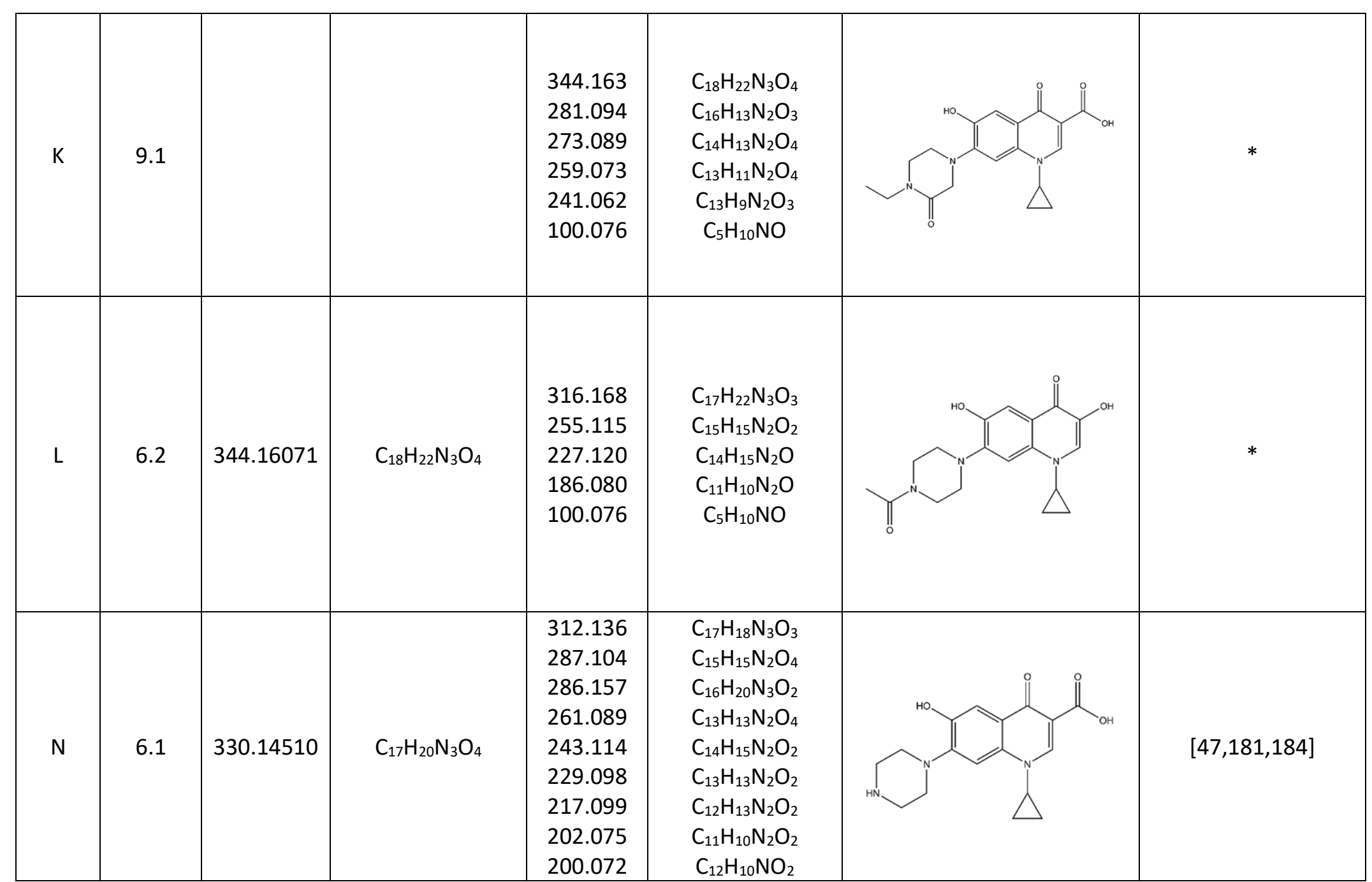



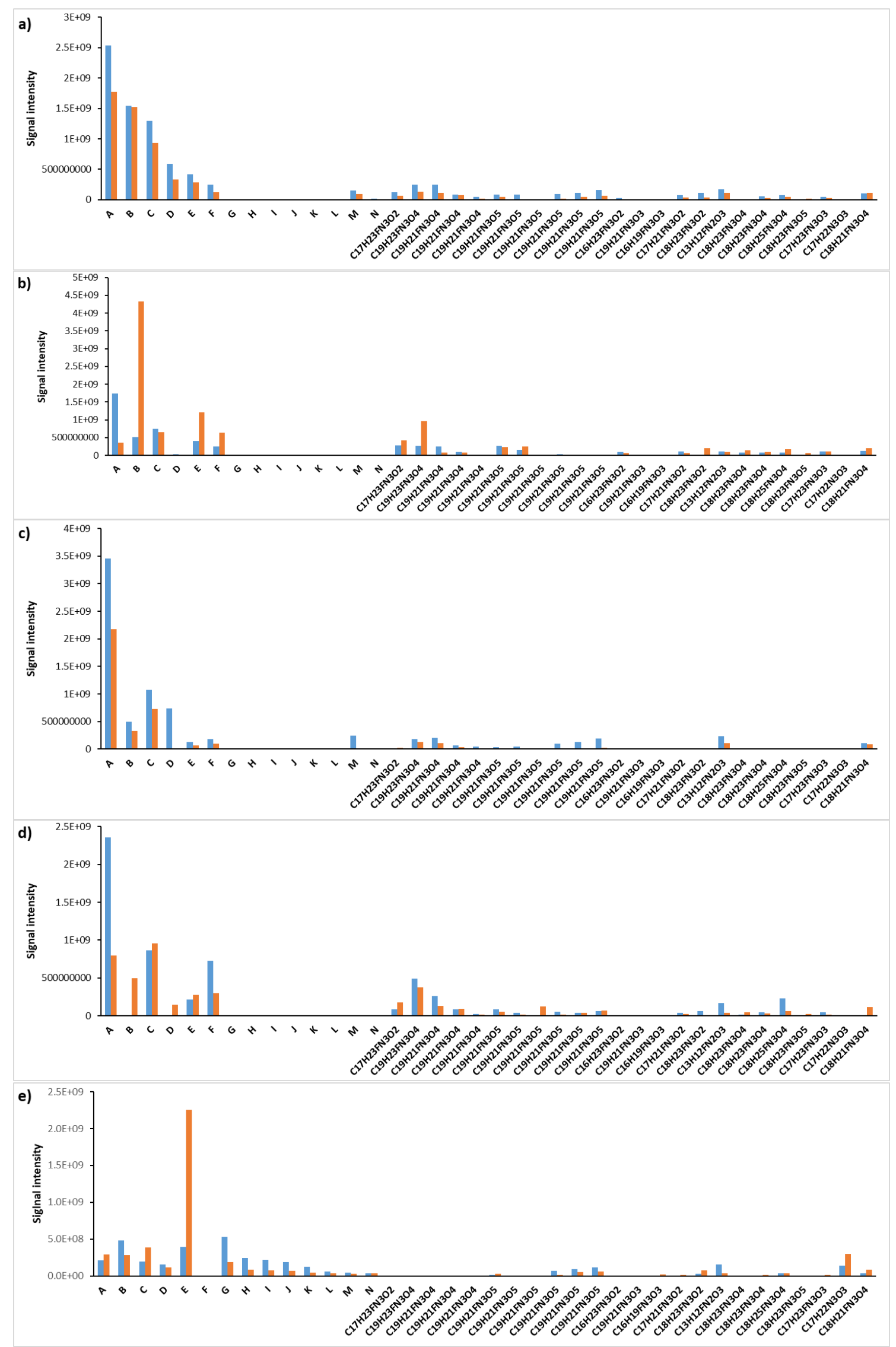


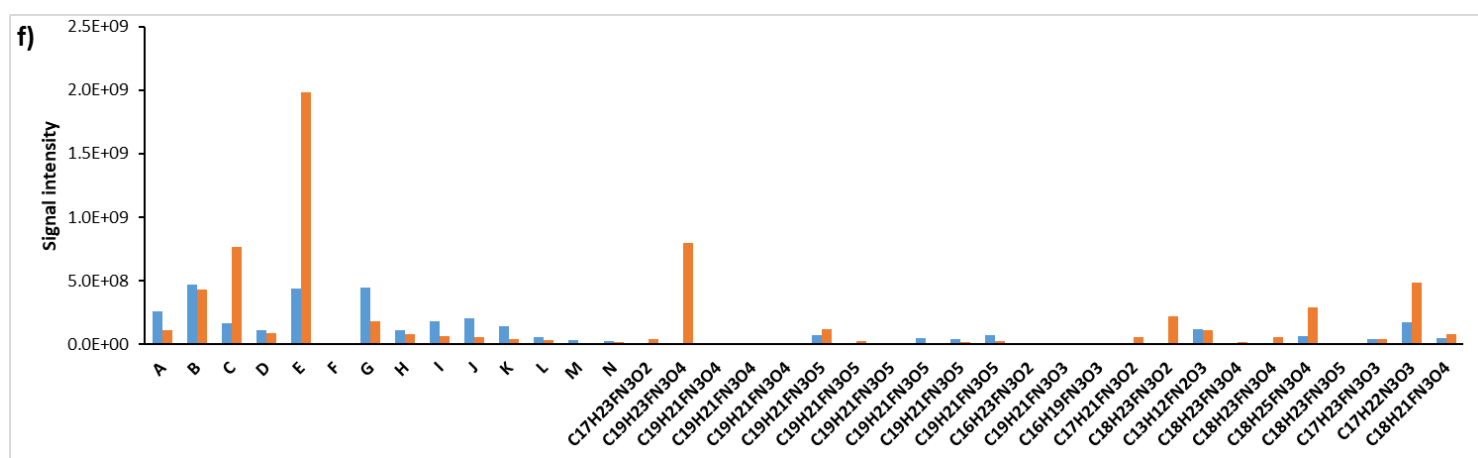

Figure 4.11. All detected photoproducts for ENR $300 \mu \mathrm{M}$ (blue) and Fe $\mathrm{III}_{\text {-ENR }} 100 \mu \mathrm{M}$ (orange) after 120 min of: a) hv pH 3.0; b) $\mathrm{H}_{2} \mathrm{O}_{2}+$ hv pH 3.0; c) hv + IPA pH 3.0; d) hv + $\mathrm{H}_{2} \mathrm{O}_{2}+$ IPA pH 3.0; e) hv pH 7.0; f) $\mathrm{H}_{2} \mathrm{O}_{2}+$ hv pH 7.0 [118].

Observing Figure 4.12, since complexation reduced the direct photolysis of the FQ, lower photoproduct formation was obtained in the case of the iron-complex form at both studied $\mathrm{pH}$ without $\mathrm{H}_{2} \mathrm{O}_{2}$. Analysing $\mathrm{pH}$ 3.0, photodegradation pathways did not differ significantly between ENR and $\mathrm{Fe}^{\mathrm{III}}$-ENR $\mathrm{EN}_{3}$, observing in both cases that the main reaction was ethyl loss from piperazinyl ring, forming photoproduct A, ciprofloxacin (another commercial FQ), which is in agreement with related studies that have indicated it as the common path for ENR photolytic degradation $[48,71,176]$. Similarly, photoproduct C, still with no modification on the FQ core, presents rupture on the piperazinyl ring. Only in the cases of B, D, E and M, oxidation of chromophoric part of ENR became relevant. In addition, the use of IPA showed the expected decrease of hydroxylated photoproducts formation (Figure 4.11C), even though it had not significantly affected the pollutant degradation kinetics (Figure 4.4A-B).

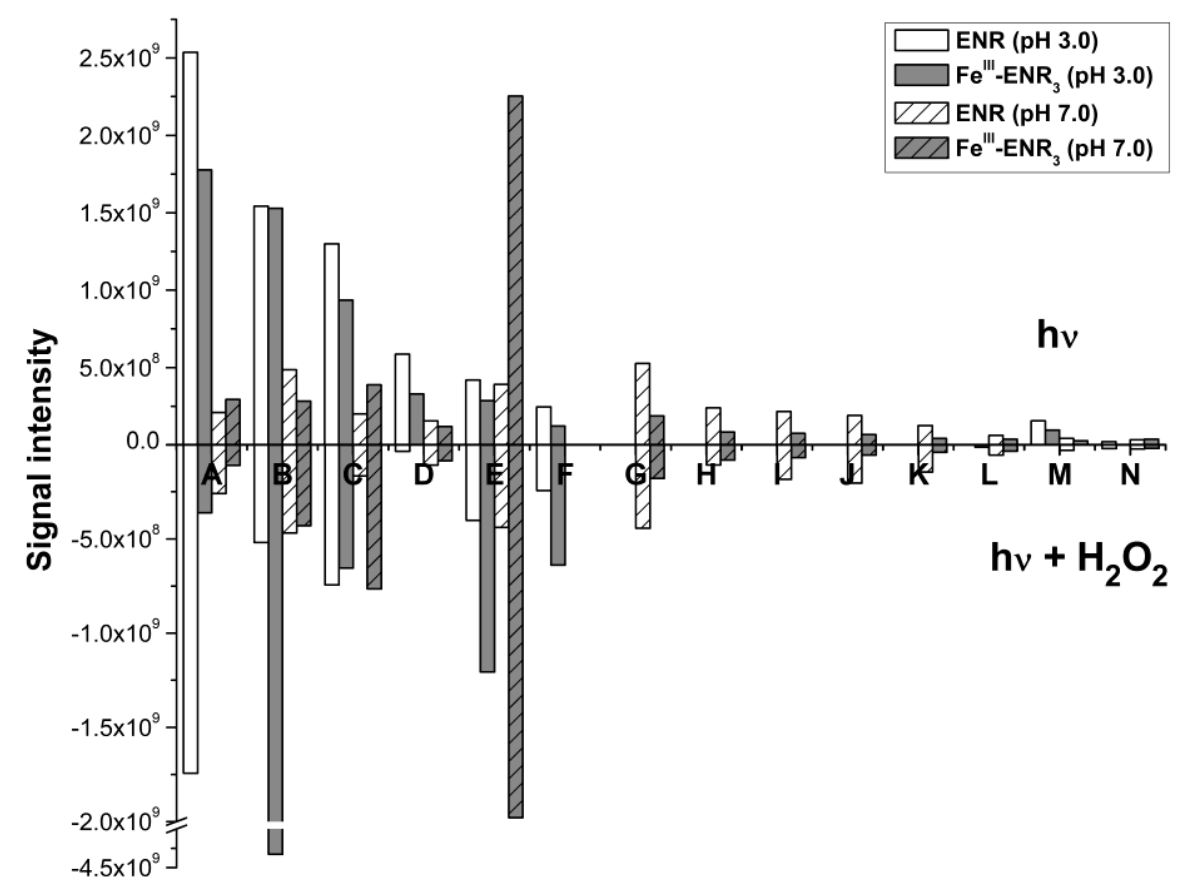

Figure 4.12. Obtained photoproducts formation after $120 \mathrm{~min}$ for $\mathrm{ENR} 300 \mu \mathrm{M}$ and $\mathrm{Fe}^{\mathrm{III}}$-ENR $\mathrm{EN}_{3} 100 \mu \mathrm{M}$, pH 3.0 and 7.0. Above with only light irradiation (hv), and below with $\mathrm{hv}+\mathrm{H}_{2} \mathrm{O}_{2} 200 \mu \mathrm{M}$ [118]. 
In sharp contrast with acidic conditions, at $\mathrm{pH} 7.0$ without $\mathrm{H}_{2} \mathrm{O}_{2}$, photoproduct formation was notably distinctive when ENR was chelating iron compared to when it was not. In both cases, a higher variety of photoproducts were observed than the ones obtained at $\mathrm{pH} 3.0$, presenting more defluorinated compounds, without decarboxylation $(\mathrm{H}, \mathrm{J}, \mathrm{K}$, and $\mathrm{N})$ and also decarboxylated (G, I and L). These reactions have been reported in the literature as common paths for FQ photolysis for zwitterionic chemical speciation form rather than for the cationic one $[45,181]$. Moreover, in the case of $\mathrm{Fe}^{\mathrm{III}}-\mathrm{ENR}_{3}$, fluorine substitution by hydroxyl group (photoproduct E) has been observed as the favored path, in contrast with the prevalent ciprofloxacin (photoproduct A) formation at pH 3.0. Without Fe(III) complexation, there was no formation of a single major photoproduct, but a wider variety of transformation products were detected in lower quantities.

It is well known that photo-induced decarboxylation reactions occur on $\mathrm{Fe}$ (III)carboxylate complexes under sun-simulated irradiation $[61,185,186]$. However, in this case, lower decarboxylation was observed in the case of $\mathrm{Fe}^{\mathrm{III}}-\mathrm{ENR}_{3}$ than ENR, which is in agreement with previous observations reported in section 4.1.3.2.3, describing no significant iron loss during the $120 \mathrm{~min}$ of $\mathrm{Fe}^{\mathrm{III}}-\mathrm{ENR}_{3}$ irradiation at $\mathrm{pH}$ 7.0. This trend could be probably explained by the chelation mode between ENR and Fe(III) between the carbonyl and carboxyl groups of FQs, hence being an overall protection of the carboxylic acidic group. Nevertheless, the difference between the decarboxylation of ENR and $\mathrm{Fe}^{\mathrm{III}}-\mathrm{ENR}_{3}$ is the same as for the other photoproducts, obtaining maybe higher photoproduct formation for the non-complexed pollutant. Therefore, no conclusion can be taken from an enhancement or inhibition of decarboxylation between ENR and $\mathrm{Fe}^{\mathrm{III}}-\mathrm{ENR}_{3}$.

When $\mathrm{H}_{2} \mathrm{O}_{2}$ was added, at $\mathrm{pH}$ 3.0, formation of hydroxylated by-products ( $\mathrm{B}, \mathrm{E}$ and $\mathrm{F}$ ) occurred at a higher extent in the case of $\mathrm{Fe}^{\mathrm{III}}-\mathrm{ENR}_{3}$, which is in agreement with the higher $\bullet$ OH production due to the photo-Fenton process. These differences are clearer when analysing the respective obtained photoproduct formation kinetics (Figure 4.13A-B) noticing that not only the order of formation was different, but the rates as well. Interestingly, decarboxylation was negligible compared to direct photolysis (without $\mathrm{H}_{2} \mathrm{O}_{2}$ ), where $\mathrm{D}$ and $\mathrm{M}$ were obtained in higher amounts.

In the case of $\mathrm{pH}$ 7.0, the addition of $\mathrm{H}_{2} \mathrm{O}_{2}$ did not alter the photodegradation mechanism of ENR compared to the results without the addition of it. On the other hand, despite the fact that with $\mathrm{Fe}^{\mathrm{III}}-\mathrm{ENR}_{3}$ differences were not as clear as the ones at $\mathrm{pH}$ 3.0, when analysing Figure 
4.11E-F, enhanced oxidized products were formed when $\mathrm{H}_{2} \mathrm{O}_{2}$ was added, results that are in agreement with the ones shown in section 4.1.3.3.
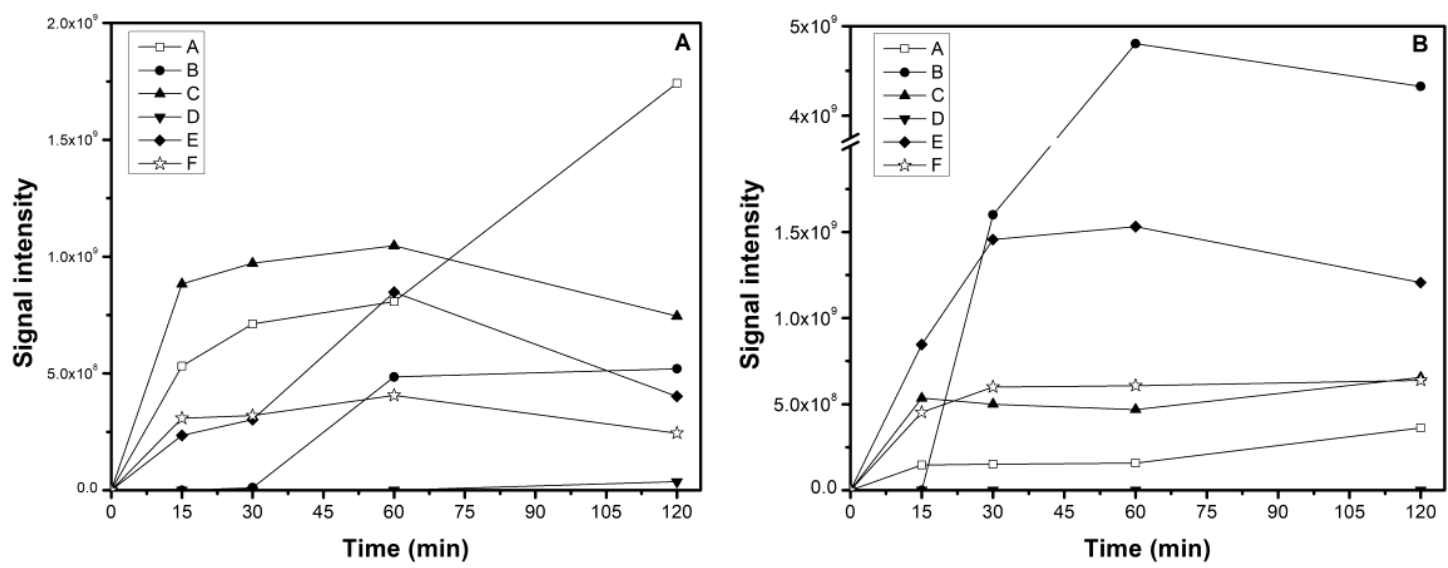

Figure 4.13. Photoproduct formation kinetics when $\mathrm{H}_{2} \mathrm{O}_{2} 200 \mu \mathrm{M}$ was added at pH 3.0 to: A) ENR 300 $\mu M$, B) Fe $\mathrm{F}^{\mathrm{III}}$-ENR $100 \mu \mathrm{M}[118]$.

\subsubsection{Conclusions}

Our results demonstrate that iron, ubiquitous metal in water compartment as well as catalyst reagent in photo-Fenton type processes, can strongly affect the photochemical processes of ENR also frequently found in aqueous media. Indeed, when iron, coexist with ENR, they form a stable complex within a wide $\mathrm{pH}$ range, affecting each other's photochemistry, in particular, decreasing ENR photolytic rate constant, thus probably enhancing their persistence in the environment. Photoproduct formation pathway is also affected by metal chelation. The FQ-Fe(III) complex was efficiently removed from water only with the addition of $\mathrm{H}_{2} \mathrm{O}_{2}$, due to photo-Fenton process. In this sense, even though FQs could be photochemically stabilized in the presence of $\mathrm{Fe}(\mathrm{III})$, this coexistence could represent an advantage when achieving Fenton-type treatment at circumneutral $\mathrm{pH}$ for the degradation of more recalcitrant pollutants.

\subsection{Magnetic Photocatalyst for Wastewater Tertiary Treatment at Pilot Plant Scale: Disinfection and Enrofloxacin Abatement}

This section shows the information from the publication referenced as [187]: Sciscenko, Iván; Mestre, Sergio; Climent, Javier; Valero, Francisco; Escudero-Oñate, Carlos; Oller, Isabel; Arques, Antonio. Magnetic Photocatalyst for Wastewater Tertiary Treatment at Pilot Plant Scale: Disinfection and Enrofloxacin Abatement. Water 2021, 13, 329. https://www.mdpi.com/2073-4441/13/3/329 
This results were obtained during the secondment at FACSA under the supervision of Dr. Javier Climent and Mr. Francisco Valero. Photocatalyst characterization was performed by Dr. Sergio Mestre (Universitat Jaume I, Castellón, Spain).

\subsubsection{Introduction}

Inspired by the challenges faced by the aforementioned Spain southeast region (and water-scarcity in general) and the need to incorporate AOP technology in MWWTPs using the previously existing set-ups as much as possible, experiments at the pilot plant scale by using $\mathrm{UVC}, \mathrm{H}_{2} \mathrm{O}_{2} / \mathrm{UVC}$, photo-Fenton and heterogeneous photocatalysis with the Magnox material (Magnox/UVC) are reported in this work. Two model compounds have been selected as target: rhodamine-B (RB) has been employed to characterize the system under the different operating conditions; this dye was chosen because it is commonly employed and easy to monitor spectrophotometrically [188-190]. Then, the degradation of ENR was studied under selected conditions.

Finally, the best treatments have been tested with real MWWTP secondary treatment effluent from Alhama de Murcia (Spain) (which treats wastewater coming from an equivalent population of 22,857 inhabitants) managed by FACSA company. Disinfection (elimination of Escherichia coli and Clostridium perfringens) and effect on physical-chemical parameterse.g., COD, TOC, and transmittance percentage at $254 \mathrm{~nm}\left(\mathrm{~T}_{254}\right)$ were monitored, the latter being an indicator of UV irradiance flux through the treated water; hence, it is related to the proliferation of aquatic microorganisms [14].

\subsubsection{Experimental}

\subsubsection{Reagents}

Rhodamine-B, $\mathrm{FeSO}_{4} \cdot 7 \mathrm{H}_{2} \mathrm{O}, \mathrm{H}_{2} \mathrm{O}_{2}(33 \% \mathrm{w} / \mathrm{v}), \mathrm{Na}_{2} \mathrm{SO}_{3}$, methanol and acetonitrile were purchased from PanReac-Applichem. High purity (> 99\%) enrofloxacin was obtained from Sigma-Aldrich. Formic acid was purchased from VWR Chemicals and $\mathrm{H}_{2} \mathrm{SO}_{4}$ was supplied by Quimivita. Experiments were performed with tap water $(\mathrm{pH}=7.9$, total inorganic carbon $=38$ $\mathrm{mg} / \mathrm{L},\left[\mathrm{Cl}^{-}\right]=70 \mathrm{mg} / \mathrm{L},\left[\mathrm{SO}_{4}{ }^{2-}\right]=202 \mathrm{mg} / \mathrm{L}$, conductivity $\left.=550 \mu \mathrm{S} / \mathrm{cm}\right)$, and MWWTP secondary effluent $\left(\mathrm{pH}=7.8,\left[\mathrm{Cl}^{-}\right]=494 \mathrm{mg} / \mathrm{L},\left[\mathrm{SO}_{4}{ }^{2-}\right]=483 \mathrm{mg} / \mathrm{L}\right.$, conductivity $=3221$ $\mu \mathrm{S} / \mathrm{cm}, \mathrm{COD}=32 \mathrm{mg} / \mathrm{L}, \mathrm{TOC}=21 \mathrm{mg} / \mathrm{L}, 50 \% \mathrm{~T}_{254}$, E. coli $140 \mathrm{CFU} / \mathrm{mL}$ and $C$. perfringens spores $5.80 \mathrm{CFU} / \mathrm{mL})$. 
Magnox particles were synthetized by employing a suspension of $\mathrm{Fe}_{3} \mathrm{O}_{4}$ particles (Bayferrox B360 Lanxess), colloidal silica (Ludox PT-40 Grace) and titania slurry (Aerodisp W740X - Evonik).

In microbiological measurements, Sartorius nitrocellulose filters, pore size $0.45 \mu \mathrm{m}$, were employed. Lactose TTC Agar/Tergitol 7 culture medium was purchased from VWR Chemicals, and agar TSC was obtained from Scharlau.

\subsubsection{Photocatalyst Synthesis and Characterization}

Magnox particles were synthetized in two steps. First, a suspension of $\mathrm{Fe}_{3} \mathrm{O}_{4}$ particles in colloidal silica in a relation of $1 / 20$ in weight was spray-dried in a pilot-scale spray-drier, obtaining particles with a magnetic core and a silica shell. Afterwards, a suspension of these core-shell particles in a titania slurry was prepared in a relation 1/12 in weight and dried with the same spray-drier. The obtained product consisted of particles with cores of magnetite, transition shells of silica, and surfaces of photocatalytic $\mathrm{TiO}_{2}$. The as-synthesized particles were calcined at $600{ }^{\circ} \mathrm{C}$ for $1 \mathrm{~h}$ in a laboratory electric furnace (RHF1600, Carbolite Furnaces Ltd.) to sinter the materials and improve their mechanical properties. The obtained particles had a theoretical composition of $1.9 \mathrm{Fe}_{3} \mathrm{O}_{4}, 15.3 \mathrm{SiO}_{2}$, and $82.8 \mathrm{TiO}_{2}$ (wt.\%).

Magnox particles presented a true density of $3.4 \times 10^{3} \mathrm{~kg} / \mathrm{m}^{3}$ (measured by a helium stereopycnometer, UPY-10T Ultrapycnometer, Quantachrome Instruments) and a specific surface of $59 \mathrm{~m}^{2} / \mathrm{g}$ (measured by BET method with a TriStar 3000, Micromeritics Instrument Corp.). SEM analysis (ESEM Quanta 200, FEI Corp.) estimated a particle size range between 20 and $200 \mu \mathrm{m}$ (Figure 4.14A) and confirmed the expected structure of the particles: an internal layer of the mixture magnetite+silica and an external layer of titania (Figure 4.14B). The central pore is a characteristic of spray-dried materials which can facilitate the fluidization of the particles in the reactor if it is completely closed. 


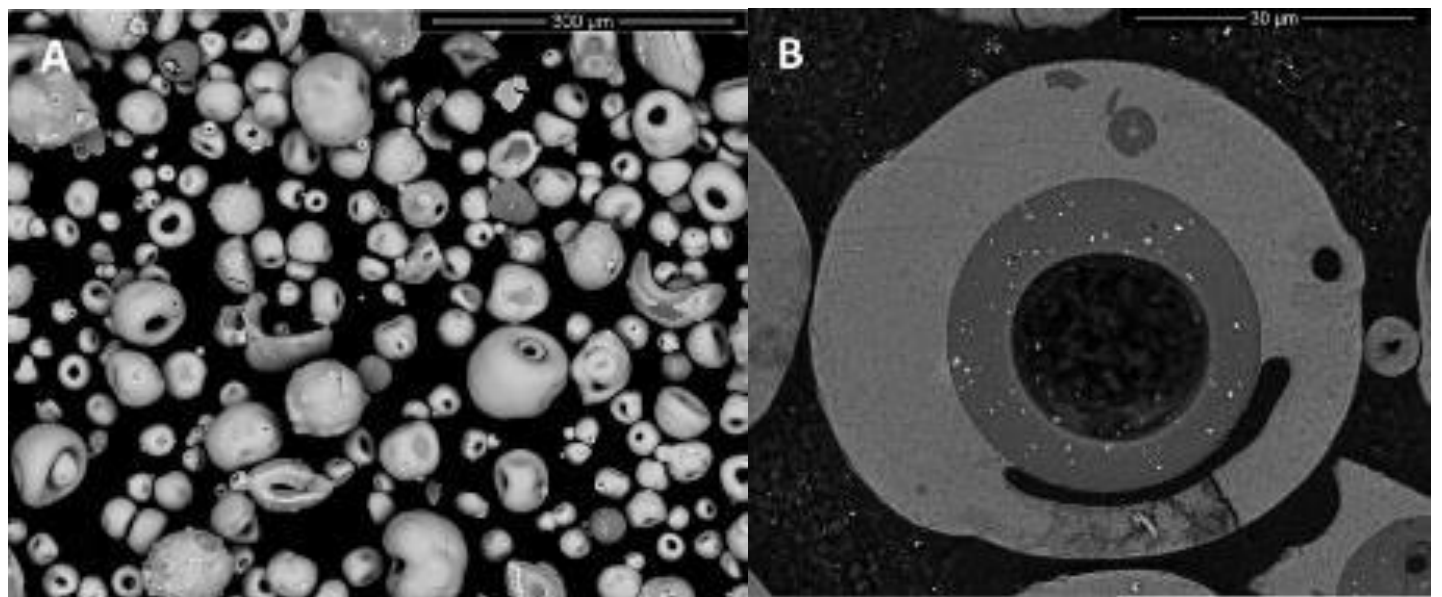

Figure 4.14. SEM images from Magnox photocatalyst: (A) general view of the particles; (B) sectioned and polished particle showing the silica (dark layer surrounding the central pore), magnetite (brightest points inside silica layer), and titanium oxide (the grey layer around silica layer) [187].

\subsubsection{Chemical and Microbiological Analysis}

The decoloration of the solutions containing RB was tracked following the absorbance decay at $552 \mathrm{~nm}$ by means of a spectrophotometer (Hach-Lange). The same apparatus was employed to determine the transmittance of MWWTP effluent at $254 \mathrm{~nm}$.

ENR concentration was determined with a Hitachi Chromaster high pressure liquid chromatography (HPLC) coupled with a UV/Vis detector. The column was a Machery-Nagel C18 Nucleodur $-\pi^{2} 5 \mu \mathrm{m}$. The elution was performed in isocratic mode at $0.25 \mathrm{~mL} / \mathrm{min}$ and the eluent consisted of a mixture formic acid $0.1 \mathrm{M} 80 \%$ and acetonitrile $20 \%$. The oven was set to $40{ }^{\circ} \mathrm{C}$ and the detection was performed at $275 \mathrm{~nm}$.

The degree of mineralization was obtained with the experiments following the decrease in TOC. These analyses were performed on Shimadzu TOC-V equipment with a Shimadzu ASI-V autosampler. COD was also monitored using a photometric method (Merck Cell test) and by measuring the resulting color on a Merck Prove 300 photometer. The decay of $\mathrm{H}_{2} \mathrm{O}_{2}$ concentration in the time-course experiments was measured using MQuant peroxide indicator test strips.

Microbiological analyses were performed employing permanently sterile material. For E. coli measurements, $100 \mathrm{~mL}$ of MWWTP diluted samples (1:100) were passed through Sartorius (Göttingen, Germany) nitrocellulose filters, with pore sizes of $0.45 \mu \mathrm{m}$, which was afterwards placed on a Lactose TTC Agar/Tergitol 7 culture medium. The number of colony formation units (CFUs) was determined after $24 \mathrm{~h}$ incubation at $45^{\circ} \mathrm{C}$. C. perfringens spore content was determined by Iproma laboratories based on ISO 14189:2013. The employed methodology consisted of a heat pre-treatment at $60^{\circ} \mathrm{C}$ for $15 \mathrm{~min}$ for inactivation of bacteria 
in a vegetative state. The samples were filtered afterwards, and the filter was placed on Agar TSC. An incubation in an anaerobiosis generation system at $44{ }^{\circ} \mathrm{C}$ for $21 \mathrm{~h}$ was performed, measuring the respective CFUs by phosphatase alkaline assay (Sifin) according to ISO 14189 .

\subsubsection{Experimental Procedures and Set-Up at Pilot Plant Scale}

Experiments with model compounds were performed in tap water at $\mathrm{pH} 2.8$ (employing $\mathrm{H}_{2} \mathrm{SO}_{4} 96 \%$ ) and natural 7.7. The initial concentration of the tested pollutants was $5 \mathrm{mg} / \mathrm{L}$ for $\mathrm{RB}$ and $25 \mathrm{mg} / \mathrm{L}$ in the case of ENR; the latter was only explored at $\mathrm{pH} 2.8$. Pollutant concentrations were high enough to measure mineralization percentages accurately. The described solutions have shown to be stable under dark conditions and air bubbling $(30 \mathrm{~L} / \mathrm{min})$ for at least $2 \mathrm{~h}$. The $\mathrm{H}_{2} \mathrm{O}_{2} / \mathrm{UVC}$ process was studied by employing the stoichiometric amount of $\mathrm{H}_{2} \mathrm{O}_{2}$ for mineralization of the tested pollutants ( 25 and $125 \mathrm{mg} / \mathrm{L}$ of $\mathrm{H}_{2} \mathrm{O}_{2}$ for $\mathrm{RB}$ and $\mathrm{ENR}$, respectively). This is a useful procedure commonly employed to normalize the amount of hydrogen peroxide added to the reaction medium and to ensure that the process is not stopped because of the exhaustion of this reagent [191]. The same conditions were employed for photoFenton experiments (in both studied pHs, 2.8 and natural 7.7), but with the addition of $5 \mathrm{mg} / \mathrm{L}$ of $\mathrm{Fe}(\mathrm{II})$ added from a stock solution prepared with $\mathrm{FeSO}_{4} \cdot 7 \mathrm{H}_{2} \mathrm{O}$, which is a concentration that has been shown to be effective according to previous works [140,191], and it is also the maximum recommended level for treated wastewater according to the FAO [192]. In the experiments involving Magnox, the desired amount of this solid catalyst was added directly into the pilot plant, leaving $10 \mathrm{~min}$ before turning on the UVC lamp to ensure complete homogenization.

Experiments were conducted in the reactor pilot plant depicted in Figure 4.15. In total, $45 \mathrm{~L}$ of solution was loaded into a conical vessel with vertical agitation, from the bottom of which the mixture was pumped through a commercial vertical photo-reactor (ATG model UVLA-325-4) equipped with a 325 Watt low-pressure UVC lamp ( $\lambda \sim 254 \mathrm{~nm})$, and recirculated to the conical vessel. The photo-reactor dimensions were: $1.73 \mathrm{~m}$ total length, $1.42 \mathrm{~m}$ from inlet to outlet, and $175 \mathrm{~mm}$ distance between lamp and reactor wall. The employed pumping flow was $400 \mathrm{~L} / \mathrm{h}$ (level on which the turbulent flux is ensured) in all cases. Samples were taken from an upper tube located at the exit of the photo-reactor. Although Magnox particles presented high densities, the fluidization of the particles in the photoreactor was achieved through fine-adjustment of the air flow rate from the bottom of the column using an air compressor Metabo Basic 250-50 V. This set flow rate was sufficient when the operator visually detected fluidization of the catalyzer along $75 \%$ of the length of the column whilst 
checking that the photocatalyzer was not being washed out from the top of the reactor, with 1.5 $\mathrm{L} / \mathrm{min}$ air flow being the minimum. In terms of direction, both the air flow and the solution vertically ascended through the photo-reactor.

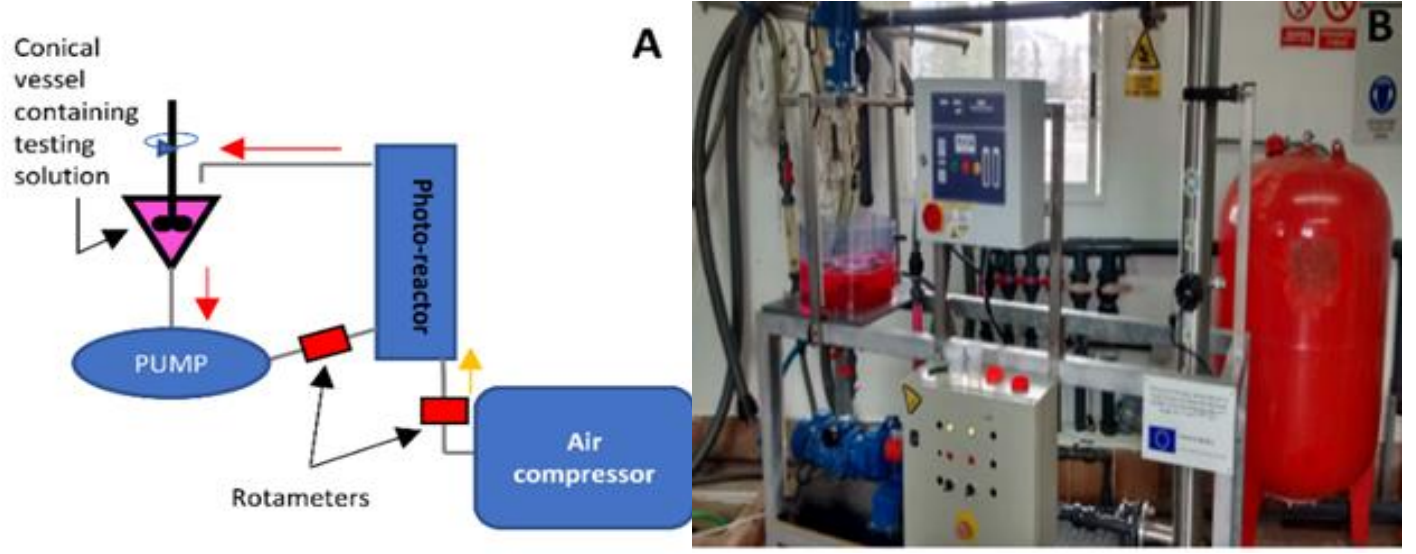

Figure 4.15. Employed pilot plant: (A) scheme and (B) picture [187].

\subsubsection{Results and Discussion}

\subsubsection{Study of the Operational Parameters}

A first series of experiments was devoted to determining the effect of Magnox initial concentration $(0.5$ and $5.0 \mathrm{~g} / \mathrm{L})$ and air flow rate $(1.5$ and $30 \mathrm{~L} / \mathrm{min})$ on the decolorization rate of the RB model dye (Figure 4.16).

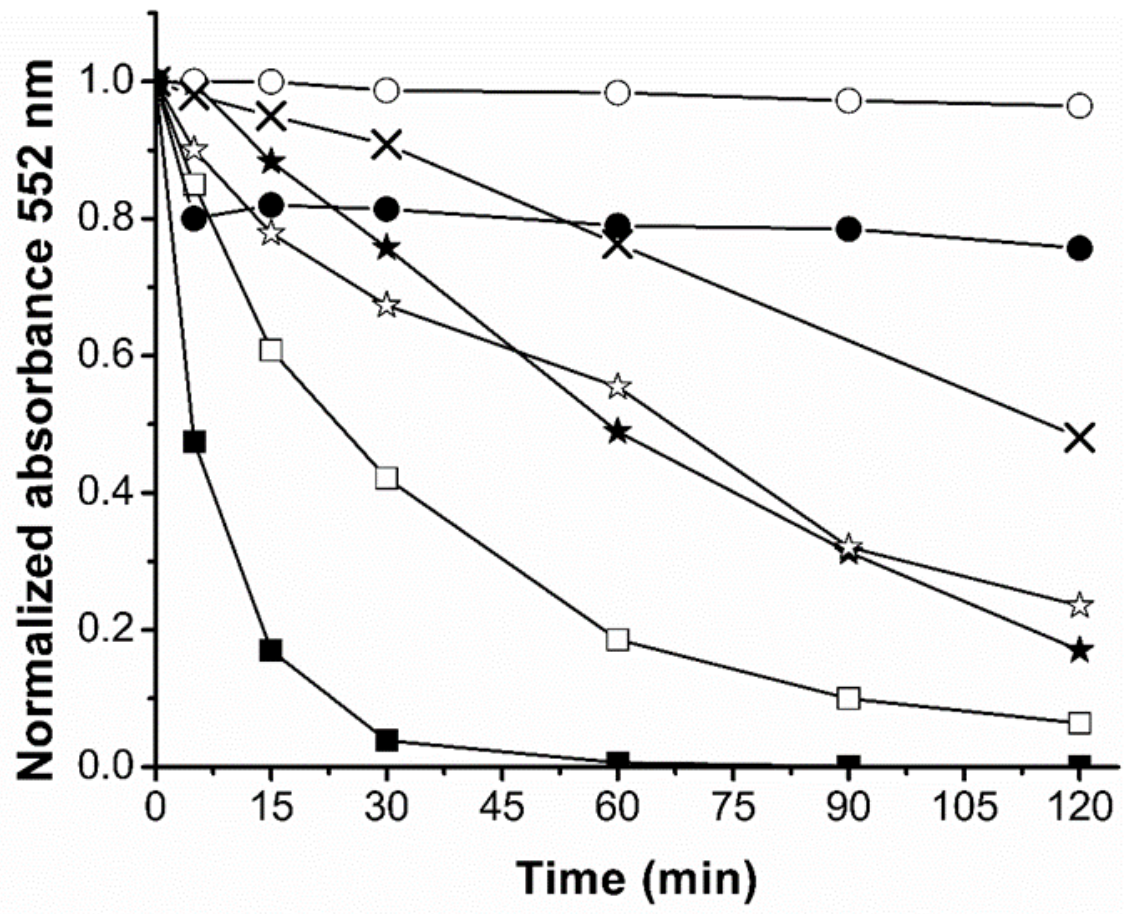

Figure 4.16. Dye decolorization (rhodamine-B (RB), $5 \mathrm{mg} / \mathrm{L}$ ) by Magnox/Ultraviolet light (UVC) within different tested operational conditions: dark controls (adsorption) with fixed air flow of $30 \mathrm{~L} / \mathrm{min}$, for 0.5 (०) and $5 \mathrm{~g} / \mathrm{L}(\bullet)$ of photocatalyst; air flow variation with fixed $0.5 \mathrm{~g} / \mathrm{L}$ of photocatalyst, 1.5 ( $\star$ ) and 30 $\mathrm{L} / \mathrm{min}(\star)$; air flow variation with fixed $5 \mathrm{~g} / \mathrm{L}$ of photocatalyst, 1.5 ( $\square$ ) and $30 \mathrm{~L} / \mathrm{min}(\square)$; UVC alone (X) with $30 \mathrm{~L} / \mathrm{min}$ air flow [187]. 
Among the seven experiments performed, the best results were obtained with $5 \mathrm{~g} / \mathrm{L}$ of Magnox and $30 \mathrm{~L} / \mathrm{min}$ air flow, as a nearly complete decolouration was reached in about 30 min. Indeed, the best performance observed at the highest air volumetric flow rate was due to the improved suspension of the solid catalyst along the photoreactor. In fact, it was also observed during experiments with $5 \mathrm{~g} / \mathrm{L}$ of Magnox and $1.5 \mathrm{~L} / \mathrm{min}$ air flow that the amount of solid during sampling diminished with time, thus indicating that the photocatalyst should be retained within the connections of the pilot plant, or even also inside the photoreactor, losing the material over the course of the experiment due to inadequate mixing. In addition, dark controls have shown that $20 \% \mathrm{RB}$ absorption on the photocatalyst was also observed when employing the $5 \mathrm{~g} / \mathrm{L}$ of photocatalyst with an air flow of $30 \mathrm{~L} / \mathrm{min}$. This was negligible with the lower tested Magnox amount. Finally, the RB decolorization by photolysis contribution is also shown with ca. $50 \%$ in $2 \mathrm{~h}$.

Therefore, we can conclude that when employing higher air flows, in addition to the likelihood of higher reactive oxygen species formation which could have enhanced the overall pollutant abatement $[61,193]$, it also increased the availability of the photocatalyst surface to the light and enhanced the mass transfer process through and from the particles. Hence, for the rest of experiments, air flows were $30 \mathrm{~L} / \mathrm{min}$. It is important to highlight that the main modifications to the photoreactor could be also taken into account, such as magnetic mixing [194], in order to avoid photocatalyst loss as well as avoiding the use of an air compressor which is expensive.

The efficiency of Magnox was compared with other AOPs that are commonly employed namely, UVC-photolysis, $\mathrm{H}_{2} \mathrm{O}_{2} / \mathrm{UVC}$, Fenton $\left(\mathrm{Fe}(\mathrm{II}) / \mathrm{H}_{2} \mathrm{O}_{2}\right)$, and photo-Fenton ( $\mathrm{Fe}(\mathrm{II}) / \mathrm{H}_{2} \mathrm{O}_{2} / \mathrm{UVC}$ ) (Figure 4.17A). It can be observed that the fastest decolorization was reached with $\mathrm{H}_{2} \mathrm{O}_{2} / \mathrm{UVC}$, followed by Magnox/UVC. Photo-Fenton also enabled fast RB decolorization (> 99\% in $30 \mathrm{~min}$ ), which was mainly attributed to the $\mathrm{H}_{2} \mathrm{O}_{2} / \mathrm{UVC}$ contribution since iron is scarcely able to drive photo-Fenton at the used $\mathrm{pH}$ values due to the formation of iron oxides, as has been widely reported [76,195]. In line with these statements, in the absence of light, the dark-Fenton process was not able to produce any effect on RB. 

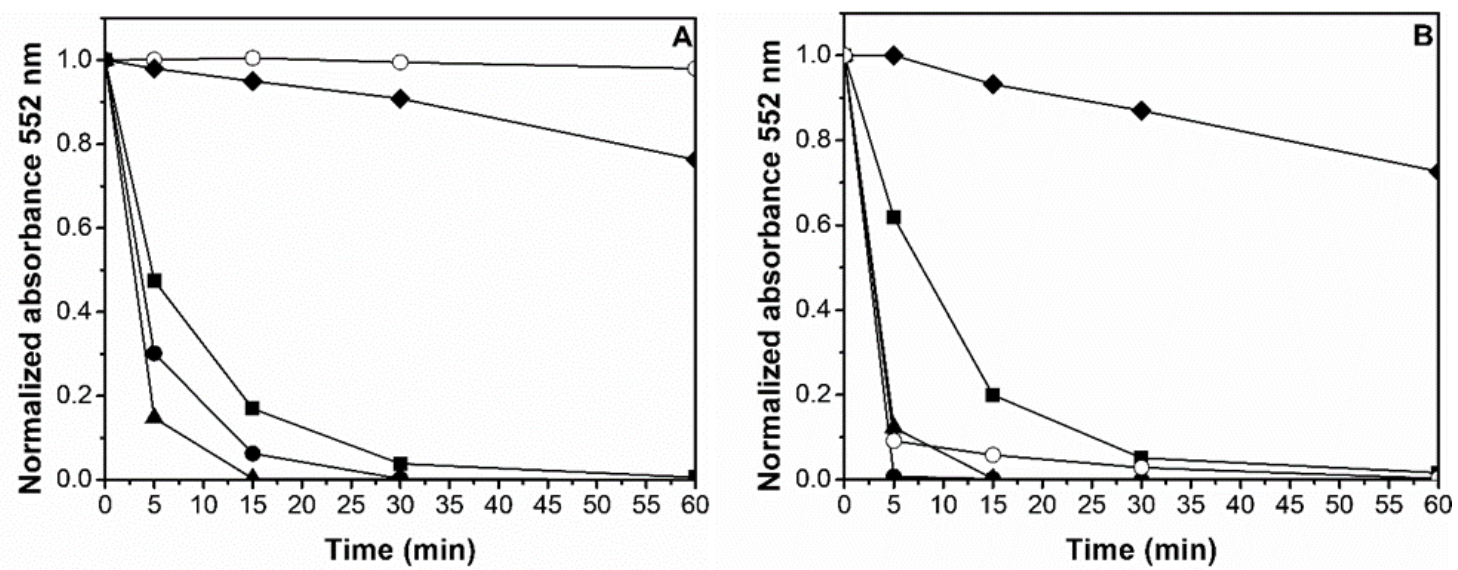

Figure 4.17. Dye decolorization (RB $5 \mathrm{mg} / \mathrm{L}$ ) profiles with the different studied Advanced Oxidation Processes (AOPs) with air flow of $30 \mathrm{~L} / \mathrm{min}$ at (A) natural $\mathrm{pH}$ and $(\mathrm{B}) \mathrm{pH} 2.8$. Studied processes are represented as follows: UVC $(\diamond)$, Magnox/UVC $(\bullet), \mathrm{H}_{2} \mathrm{O}_{2} / \mathrm{UVC}(\Delta)$, Fenton $(\odot)$, and photo-Fenton $(\bullet)$ [187].

Putting all these data together, it can be stated that only $\mathrm{H}_{2} \mathrm{O}_{2} / \mathrm{UVC}$, photo-Fenton and Magnox/UVC were efficient under the studied operational conditions. However, changing some parameters (e.g., $\mathrm{pH}$ ) might result in a dramatic change in these conclusions (Figure 4.17B). For instance, photo-Fenton at $\mathrm{pH}=2.8$, which is the optimal value for this process [90], was able to completely decolorize the solution in $5 \mathrm{~min}$, while $90 \%$ decrease in the absorbance was reached for dark-Fenton under the same conditions. On the other hand, $\mathrm{pH}$ had no significant effect on the UVC, Magnox/UVC or $\mathrm{H}_{2} \mathrm{O}_{2} / \mathrm{UVC}$ processes.

\subsubsection{Enrofloxacin Removal and Mineralization}

In order to gain further insight into the efficiency of each AOP studied on the degradation of a more complex pollutant commonly found in real effluents, ENR was chosen as a target compound. This product is a widely employed antibiotic that belongs to the family of fluoroquinolones $[43,196]$ and, furthermore, its photo-Fenton degradation has been recently studied by the authors [137].

The ENR removal experiments were performed at an initial $\mathrm{pH}$ of 2.8, a condition where all the tested AOPs have shown the best RB decolorization rates (Figure 4.17B), employing an air flow rate of $30 \mathrm{~L} / \mathrm{min}$ (Figure 4.18A). In coincidence with RB degradations at acidic conditions, ENR presented fast total removals with all the tested AOPs. Fenton and photoFenton were very efficient in ENR removal, but the combination of $\mathrm{H}_{2} \mathrm{O}_{2} / \mathrm{UVC}$ was also able to completely abate this antibiotic in $15 \mathrm{~min}$. In the case of Magnox/UVC, even though the reaction was notably slower than the ones employing hydrogen peroxide, ENR removal was still faster than with UVC alone, thus demonstrating again the photocatalytic activity of the material. 

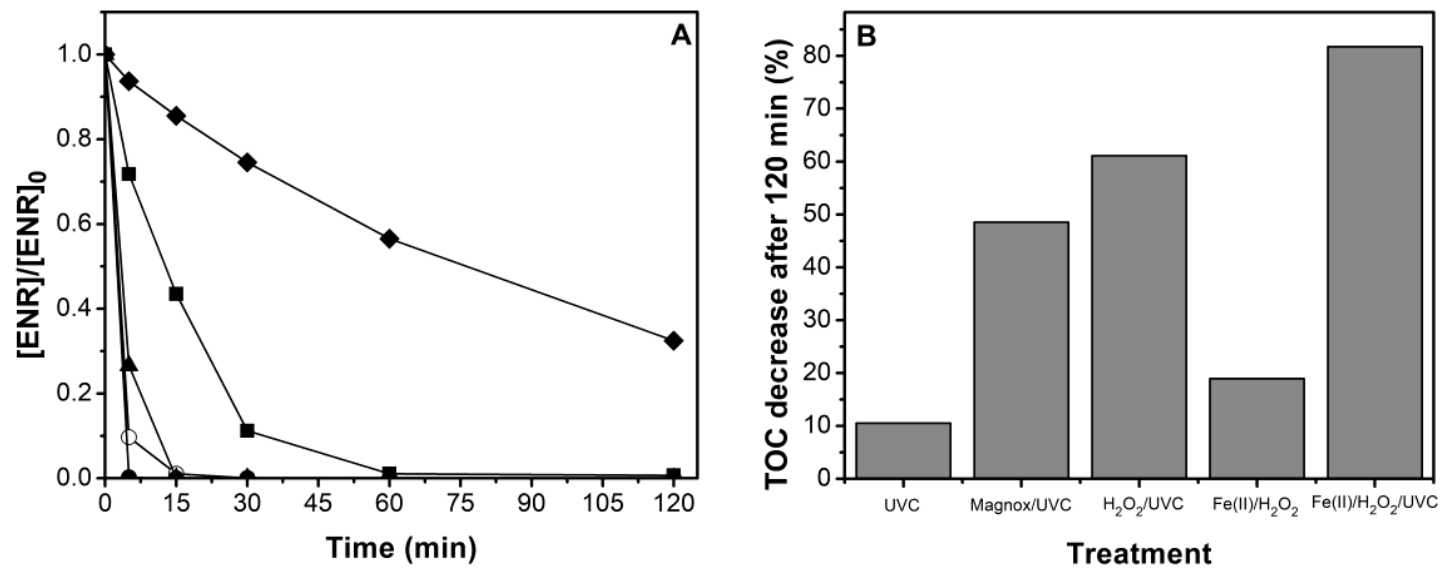

Figure 4.18. Enrofloxacin (ENR) $25 \mathrm{mg} / \mathrm{L}$ removals at pH 2.8 with air flow of $30 \mathrm{~L} / \mathrm{min}$. (A): UVC ( $\diamond)$ Magnox/UVC ( $(\bullet), \mathrm{H}_{2} \mathrm{O}_{2} / \mathrm{UVC}(\Delta)$, Fenton ( $($ ), and photo-Fenton ( $\bullet$ ); (B) mineralization percentages [187].

Mineralization of ENR was also followed and some interesting variations in the trends were observed: high degree of mineralization (above 50\% after $120 \mathrm{~min}$ ) was reached for the three processes following the rates trend: photo-Fenton $>\mathrm{H}_{2} \mathrm{O}_{2} / \mathrm{UVC}>$ Magnox/UVC (Figure 4.18B). On the other hand, the decrease in TOC for Fenton and UVC was much lower (below $20 \%$ after $120 \mathrm{~min})$.

\subsubsection{Magnox/UVC Influence on MWWTP Water}

Having already studied the CEC removal efficiency of Magnox/UVC, in order to gain further insight into the real applicability of the Magnox/UVC process, the best operating conditions previously selected were applied to MWWTP secondary treatment effluent. In this way, we can analyze the behavior of the water matrix with the photocatalyst so the combination of trace amounts of CECs in MWWTP water could be better explained in further studies.

In these experiments, the concentration of Magnox was $5 \mathrm{~g} / \mathrm{L}$ and the pump and air flows were fixed at $400 \mathrm{~L} / \mathrm{h}$ and $30 \mathrm{~L} / \mathrm{min}$, respectively. Five parameters were chosen to track the effect of the treatment: a physical parameter (i) transmittance; two chemical gross parameters related to the presence of organic matter, namely, (ii) COD and (iii) TOC; the CFUs of two relevant microbiological species, (iv) Escherichia coli and (v) Clostridium perfringens. UVC irradiation in the absence of Magnox was also tested. As a summary, the results obtained after 120 min of treatment are shown in Table 1. It can be observed that $120 \mathrm{~min}$ of irradiation was able to reach full bacteria content inactivation with and without Magnox, thus showing that UVC is powerful enough to disinfect the studied water. However, differences among both methods can be observed in the other assessed parameters. In this case, none of the employed technologies were able to yield complete removal of the organic matter, although better results were reached with the Magnox/UVC. 
Table 4.2. UVC and Magnox/UVC tertiary treatment comparison [187].

\begin{tabular}{|c|c|c|c|c|c|}
\hline & & \multicolumn{2}{|c|}{ After 120 min UVC } & \multicolumn{2}{|c|}{$\begin{array}{l}\text { After } 120 \text { min } \\
\text { Magnox/UVC }\end{array}$} \\
\hline Parameter & $\begin{array}{l}\text { Initial } \\
\text { Value }\end{array}$ & $\begin{array}{l}\text { Final } \\
\text { Value }\end{array}$ & $\begin{array}{c}\text { Increase / } \\
\text { Decrease } \\
\text { Percentage }\end{array}$ & $\begin{array}{l}\text { Final } \\
\text { Value }\end{array}$ & $\begin{array}{l}\text { Increase/ } \\
\text { Decrease } \\
\text { Percentage }\end{array}$ \\
\hline $\begin{array}{c}\text { Transmittance } \\
254 \mathrm{~nm}(\mathrm{~T} 254) \\
(\%)\end{array}$ & 50 & 73 & 46 & 86 & 72 \\
\hline COD (mg/L) & 32 & 27 & 14 & 24 & 24 \\
\hline $\mathrm{TOC}(\mathrm{mg} / \mathrm{L})$ & 21 & 17 & 20 & 14 & 33 \\
\hline E. coli (CFU/mL) & 140 & 0 & 100 & 0 & 100 \\
\hline $\begin{array}{c}\text { C. perfringens } \\
\text { spores } \\
\text { (CFU/mL) }\end{array}$ & 5.8 & 0 & 100 & 0 & 100 \\
\hline
\end{tabular}

\subsubsection{Conclusions}

Pollutant abatement and wastewater tertiary treatment were tested with direct irradiation of UVC light and AOPs at the pilot plant scale. At neutral $\mathrm{pH}$, faster decolorization of $\mathrm{RB}$ was observed in $\mathrm{H}_{2} \mathrm{O}_{2} / \mathrm{UVC}>$ photo-Fenton > Magnox/UVC > UVC, and was negligible when using dark-Fenton. However, as expected, when setting acidic conditions, a large enhancement of degradation rate was observed with Fenton and photo-Fenton processes, attaining fast total $\mathrm{RB}$ decolorization in 60 and 5 min, respectively.

When analyzing ENR degradation at $\mathrm{pH} 2.8$, the photo-Fenton process proved to be the most efficient tertiary treatment by means of pollutant removal and mineralization. However, it should be highlighted that realistic treatment conditions included the development of the reactions at circumneutral $\mathrm{pH}$, and therefore $\mathrm{H}_{2} \mathrm{O}_{2} / \mathrm{UVC}$ becomes the best option.

Although obtained results with Magnox/UVC were slower than $\mathrm{H}_{2} \mathrm{O}_{2} / \mathrm{UVC}$ and photoFenton, the advantage of its employment at neutral $\mathrm{pH}$ is shown to be effective. Additionally, since Magnox/UVC has the additional advantage of no acid or $\mathrm{H}_{2} \mathrm{O}_{2}$ addition, as well as its plausible reusability and simple separation due to its magnetic properties, further research on photocatalyst homogenization inside the reactor is required, with the possibility of Magnox/UVC being more efficient than $\mathrm{H}_{2} \mathrm{O}_{2} / \mathrm{UVC}$; hence, it is also more cost-effective than the latter.

Finally, successful complete inactivation of bacteria was attained when applying UVC, with no need for the addition of Magnox, as a tertiary treatment after $120 \mathrm{~min}$. However, COD and TOC decreases were faster when combining UVC with the photocatalyst, also observing a faster $\mathrm{T}_{254}$ increase. 
The optimization of operational conditions, including an economical study for Magnox/UVC, toxicity assays and its employment for CEC degradation in a more realistic situation (concentration and water matrix), is certainly needed. Since the effect of the process against pollutant abatement and MWWTP water alone, respectively, had been now studied, its application to CEC in lower concentrations (i.e., $\mu \mathrm{g} / \mathrm{L}$ ) in the MWWTP wastewater will be the next step. Moreover, iron leaching from the $\mathrm{Fe}_{3} \mathrm{O}_{4}$ core should also be analysed, as well as considering the plausible contribution to enhance iron lixiviation due to $\mathrm{Fe}^{3+}$ chelation by ENR.

\subsection{Monitoring photolysis and (solar photo)-Fenton of enrofloxacin by a methodology involving EEM-PARAFAC and bioassays: Role of $\mathrm{pH}$ and water matrix}

This chapter shows the information from the publication referenced as [137]: Sciscenko, Iván; García-Ballesteros, Sara; Sabater-Marco, Consuelo; Castillo María Ángeles; EscuderoOñate, Carlos; Oller, Isabel; Arques, Antonio. Monitoring photolysis and (solar photo)-Fenton of enrofloxacin by a methodology involving EEM-PARAFAC and bioassays: Role of $\mathrm{pH}$ and

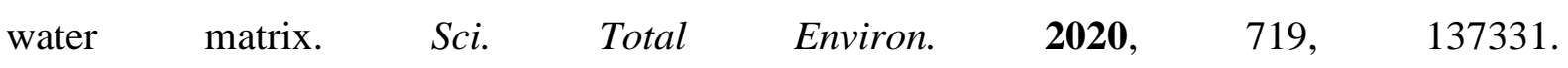
https://doi.org/10.1016/j.scitotenv.2020.137331

\subsubsection{Introduction}

In this work, we report on the degradation of ENR. Photolysis and (solar photo)-Fenton have been tested under simulated sunlight at different $\mathrm{pHs}$ (2.8 and 5.0) and using three aqueous matrices, namely ultra-pure water (MQ), tap water (TW) and highly saline water (SW), following ENR removal by HPLC and mineralization by TOC analysis. However, these tools provide only partial information on the behavior of the organic matter along the process and on the nature of the by-products that are released. Hence, implementation of a simple methodology to obtain major trends on by-products formation is needed. In this context, chemometric tools are gaining momentum, as they can extract valuable information from raw complex data [197-200].

Taking advantage of the photophysical properties of FQ-type molecules, fluorescence excitation-emission matrices (EEMs) with the multi-way method, parallel factor analysis (PARAFAC), has been selected to study the ENR degradation. Although it cannot reach the detail of sophisticated HPLC-HRMS techniques, it is easy, relatively cheap and non-time consuming. 
As far as we know, this is the first time that a FQ degradation is followed in time-course experiments using EEM-PARAFAC. Until now, only a few examples of application of this technique on FQs can be found in chemometrics [201,202] or to describe chemical interactions of these substances [203]. In addition, there are very few examples on the application of this technique to gain further insight into the efficiency of advanced oxidation processes [135,136,140]. Finally, bioassays based on the inhibition halo of E. coli and S. aureus have been used to estimate the antibacterial activity of the effluents derived from the different treatments, relating the results with all the above mentioned methodologies.

\subsubsection{Experimental}

\subsubsection{Reagents}

High purity ENR (99\%), purchased from Sigma-Aldrich, was used in all the experiments. $\mathrm{Na}_{2} \mathrm{SO}_{3}$ anhydride, $\mathrm{FeSO}_{4} \cdot 7 \mathrm{H}_{2} \mathrm{O}, \mathrm{H}_{2} \mathrm{O}_{2}$ (33\% w/v), ascorbic acid, 1,10-phenantroline 1hydrate, $\mathrm{NH}_{4} \mathrm{VO}_{3}, \mathrm{NaCl}, \mathrm{H} 2 \mathrm{SO} 496 \%$, and UHPLC grade methanol and acetonitrile were obtained from AppliChem-Panreac. 80\% formic acid was purchased from VWR Chemicals. Ultra-pure water was prepared with a Millipore system (MQ). Catalase from bovine liver (lyophilized powder 2000-5000 units/mg protein) was purchased from Sigma-Aldrich. Tap water employed in the experiments was obtained from the urban supply network of Alcoy (Spain) and had the following characteristics: $\mathrm{pH}=7.4$, inorganic carbon $=52 \mathrm{mg} / \mathrm{L}$, conductivity $=510 \mu \mathrm{S} / \mathrm{cm},\left[\mathrm{Cl}^{-}\right]=27.8 \mathrm{mg} / \mathrm{L},\left[\mathrm{SO}_{4}{ }^{2-}\right]=33.3 \mathrm{mg} / \mathrm{L}$, water hardness $=142$ $\mathrm{mg} / \mathrm{L}$ of $\mathrm{CaCO}_{3}$. Saline water was prepared by dissolving $30 \mathrm{~g}$ of $\mathrm{NaCl}$ in $1 \mathrm{~L}$ of tap water. Agar diffusion tests were made using Escherichia coli CECT 101 strain for MQ and TW assays; because of the incompatibility of $\mathrm{E}$. coli with highly saline media, the halotolerant Staphylococcus aureus CECT 435 for the SW ones. Tryptone soya broth and Mueller-Hinton broth were both provided by Scharlau.

\subsubsection{Reactions}

Reactions were carried out in cylindrical open glass reactors (total volume of $500 \mathrm{~mL}$ ). For each experiment, the reactor was loaded with $250 \mathrm{~mL}$ of ENR solution (initial concentration of $25 \mathrm{mg} / \mathrm{L}$ ), also containing $5 \mathrm{mg} / \mathrm{L}$ of $\mathrm{Fe}$ (II) (using $\mathrm{FeSO}_{4} \cdot 7 \mathrm{H}_{2} \mathrm{O}$ as the source of iron), prepared with the desired water matrix, MQ, TW or SW. Initial $\mathrm{pH}$ was adjusted to 2.8 or 5.0 by dropwise addition of $\mathrm{H}_{2} \mathrm{SO}_{4} 0.5 \mathrm{M}$ and/or $\mathrm{NaOH} 1 \mathrm{M}$. For the (solar photo)-Fenton experiments, the stoichiometric amount of $\mathrm{H}_{2} \mathrm{O}_{2}$ to mineralize ENR was added $(125 \mathrm{mg} / \mathrm{L})$; this is a useful procedure commonly employed to normalize the amount of hydrogen peroxide 
added to the reaction medium and to ensure that the process is not stopped because of the exhaustion of hydrogen peroxide [94,141]. When necessary, irradiations were performed with a solar simulator (Oriel Instrument) equipped with a high pressure Xe short arc lamp (Ushio UXL-302-0).

Experiments were run for $120 \mathrm{~min}$ and samples were taken periodically and processed differently depending on the type of analysis. In the case of HPLC and EEMs measurements, $5 \mathrm{~mL}$ of each sample were taken from the solution, and $50 \mu \mathrm{L}$ of methanol were added to quench the excess of hydrogen peroxide, thus stopping the reaction [61,204]. Then $50 \mu \mathrm{L}$ of $\mathrm{H}_{2} \mathrm{SO}_{4} 5$ $\mathrm{M}$ were added to each sample in order to ensure the acidic $\mathrm{pH}$, due to the $\mathrm{pH}$ dependence of the absorption and fluorescence spectra of ENR [205]. For TOC analysis, $\mathrm{Na}_{2} \mathrm{SO}_{3}$ was used instead of methanol to deal with the excess of $\mathrm{H} 2 \mathrm{O} 2$ in order to avoid interferences caused by the addition of extra organic substances. Finally, in the case of the bioassays, samples were previously adjusted to $\mathrm{pH} 7.0( \pm 0.5)$ with $\mathrm{NaOH} 1 \mathrm{M}$, and the remaining hydrogen peroxide was consumed by addition of catalase enzyme.

Dark controls were performed with and without iron observing no changes in the concentration of ENR. Controls with $\mathrm{H}_{2} \mathrm{O}_{2}$ without iron, and with and without irradiation, were also performed. $\mathrm{H}_{2} \mathrm{O}_{2}$ in the dark was not able to degrade ENR.

\subsubsection{Chemical analysis}

ENR concentration was determined using HPLC. The equipment consisted of a Hitachi Chromaster, equipped with a pump model 5110, a UV/Vis detector (model 5410), and oven (model 5310) and an autosampler (5210 model). A C18 Machery-Nagel column Nucleodur- $\pi^{2} 5 \mu \mathrm{m}$ was used as stationary phase and an isocratic flow of 0.25 $\mathrm{mL} / \mathrm{min}$ of formic acid 0.1 $\mathrm{M}$ and acetonitrile (80:20) was used as eluent. The oven was set at $40^{\circ} \mathrm{C}$ and the detection was performed at $275 \mathrm{~nm}$. Mineralization analyses were performed in a Shimadzu TOC-V equipment with ASI-V autosampler.

EEMs were measured with a fluorimeter Photon Technology International (PTI) QuantaMaster 400, equipped with a Xe arc lamp. The explored excitation range was $250-500 \mathrm{~nm}$ (at $5 \mathrm{~nm}$ intervals), whereas the emission range was 300-700 $\mathrm{nm}$ (also at 5 nm intervals). A Hitachi-UH5300 spectrophotometer was employed to correct the inner filter effect $(250-700 \mathrm{~nm})$. The same spectrophotometer was used to measure the dissolved total iron concentration according to the ISO 6332:1988 standardized method 
and also to monitor $\mathrm{H}_{2} \mathrm{O}_{2}$ following a modification of the metavanadate method reported by Nogueira and co-workers [144].

For the agar diffusion tests, bacteria (E.coli for MQ and TW, and S. aureus for SW) were previously grown up in a nutrient media for $18 \mathrm{~h}$. Then, colonies were inoculated in a tryptone soya broth, having a suspension of 0.5 units in McFarland scale. A sterile cotton swab was used to pick bacterial suspension and spread it on the surface of the Mueller-Hinton agar in the Petri dish. Afterwards, $0.85 \mathrm{~cm}$ wells were made and filled with $100 \mu \mathrm{L}$ of the sample. Finally, the Petri dishes were incubated at $37^{\circ} \mathrm{C}$ for 24 $\mathrm{h}$, and then the inhibition halos were read.

\subsubsection{Mathematical calculations}

PARAFAC was applied in order to analyze the underlying signals present in the obtained EEM. For this purpose, 110 EEMs, obtained from sampling ENR solutions after different periods of treatment (described in the reactions section) were recorded. PARAFAC was conducted using MATLAB 2018b with the graphical user interface EEMlab [122], which employs the routines of drEEM toolbox for the pre-treatment and analysis of the data [117].

Briefly, the procedure, which is explained in detail in the works of R. Bro $[147,206]$, consists in the following key steps: EEMs were first normalized by water Raman first order scattering signal (350 nm excitation wavelength and 365-450 nm for emission) in order to reduce error of the power lamp decay over time due to usage. Inner-filter effects were handled by uploading the absorbance spectra of each sample. MQ, TW and SW in the presence of $50 \mu \mathrm{L}$ of methanol and $50 \mu \mathrm{L}$ of $5 \mathrm{M} \mathrm{H}_{2} \mathrm{SO}_{4}$ solution were also recorded to perform the corresponding blank-subtractions to each sample. Regions affected by Rayleigh and Raman scattering were removed and data in those domains were estimated by interpolation from either sides of the bands. The correct number of components was assessed according to the chemical consistency of the obtained data, the evaluation of the distribution of the residuals and the core consistency diagnostic (CORCONDIA).

\subsubsection{Results and discussion}

4.3.3.1.ENR removals in different media 
The degradation of ENR was studied under photolysis, Fenton and solar photoFenton in MQ water at $\mathrm{pH} 2.8$ and 5.0. Plots of the normalized concentration of ENR vs. time are presented in Figure 4.19. It can be observed that, at the same pH, ENR removal was faster in photo-Fenton, followed by Fenton and finally photolysis. The $\mathrm{pH}$ effect was not important for photolysis, but (photo)-Fenton was more efficient at $\mathrm{pH}=$ 2.8 than 5.0. This should be attributed to precipitation of $\mathrm{Fe}(\mathrm{III})$ at $\mathrm{pH}$ above 3 by formation of hydroxides that are not able to participate in the Fenton process [61]. However, it is remarkable that ENR removal was still fast at $\mathrm{pH}=5.0$ by means of solar photo-Fenton (complete elimination of $25 \mathrm{mg} / \mathrm{L}$ of ENR in less than $60 \mathrm{~min}$ ). In fact, complexation of iron is one of the strategies followed to keep iron active at mild $\mathrm{pH}$ $[61,90,93]$. This effect has been observed in some compounds such as phenols, where complexation of iron by these substances shifted the optimum $\mathrm{pH}$ to values close to 4 [140]. Indeed, formation of complexes between FQs and iron has been observed and described in literature $[41,151,152]$ and their role in Fenton and related processes has been reported [171,207]. Hence, it can be proposed that ENR forms photoactive complexes with iron to explain the good efficiency of photo-Fenton at $\mathrm{pH}=5.0$. An indirect evidence is that the amount of iron remaining in the solution after photolysis remained nearly constant at $5 \mathrm{mg} / \mathrm{L}$ because of the formation of the ENR-Fe complex, in sharp contrast with the photo-Fenton experiment, where a continuous decrease in iron concentration was observed, in agreement with the destruction of ENR (in the absence of the complexant, precipitation of iron occurs). 


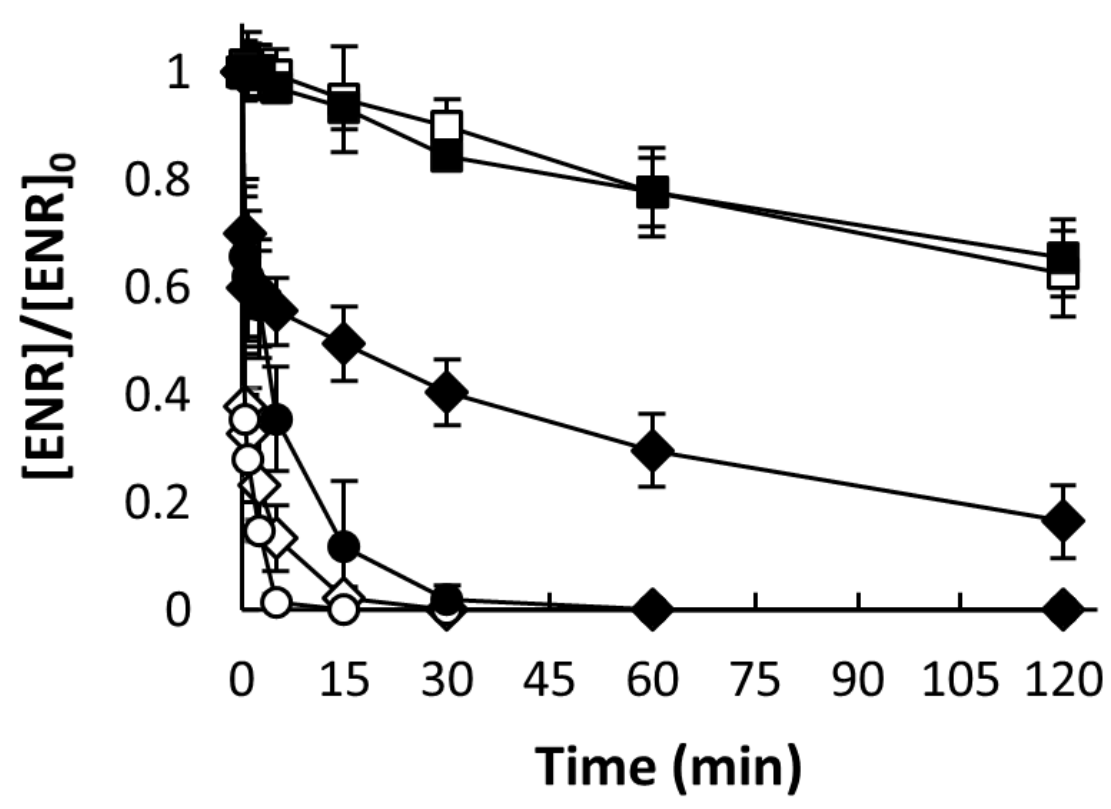

Figure 4.19. ENR degradation profiles in Milli-Q water: photolysis at $\mathrm{pH}=\mathbf{5}(\square)$; photolysis at $\mathbf{p H}=\mathbf{2 . 8}$ $(\square)$; Fenton at $\mathbf{p H}=5(\diamond)$; Fenton at $\mathbf{p H}=2.8(\diamond)$, photo-Fenton at $\mathbf{p H}=5(\bullet)$ and photo-Fenton at $\mathbf{p H}=$ $2.8(\circ)[137]$.

Water matrix effect in the ENR degradation was also studied, performing the experiments also in TW and SW. Obtained removal percentages in these conditions at both studied pHs, 2.8 and 5.0, for direct photolysis presented no significant differences with the ones obtained in MQ, being systematically in the range 20-40\% after 120 min; therefore, water constituents do not have big influence regarding direct irradiation of the compound. On the contrary, a matrix effect can be observed for Fenton and photoFenton, as shown in Figure 4.20A-B. In those cases, the fastest ENR removals were obtained in SW followed by TW and then in MQ. This primary disappearance of the parent product could be attributed to some reactivity of chlorinated radicals. As a matter of fact, in solutions containing high concentrations of chlorides, $\mathrm{Cl}^{*}$ and $\mathrm{Cl}_{2}{ }^{-}$can play an important role, as they can be formed either by direct reaction between ${ }^{\circ} \mathrm{OH}$ and $\mathrm{Cl}^{-}$, or by photolysis of iron-chloride complexes, such as $\mathrm{FeCl}^{+}, \mathrm{FeCl}^{2+}$ and $\mathrm{FeCl}_{2}{ }^{+}$ $[86,87,208]$. This is in agreement with the lower $\mathrm{H}_{2} \mathrm{O}_{2}$ consumption observed in $\mathrm{SW}$ in comparison with the other two water matrices (Figure 4.21). As a matter of fact, higher consumptions have been detected at $\mathrm{pH}=2.8$ than at 5.0, in agreement with the better performance of photo-Fenton at former conditions. 

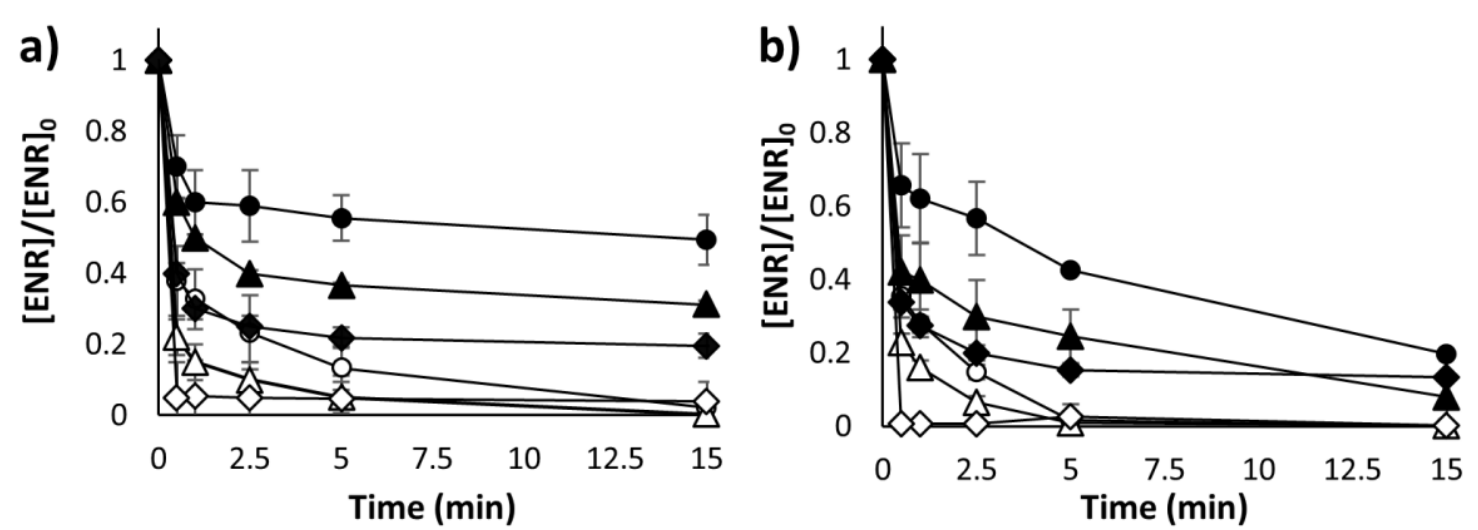

Figure 4.20. ENR removal in different aqueous media for a) Fenton, b) solar photo-Fenton. $\mathrm{SW}$ at $\mathrm{pH}=\mathbf{5}$

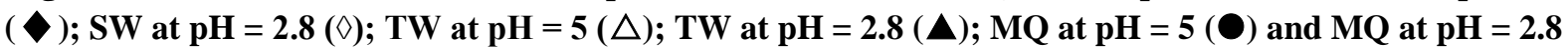
(०) [137].

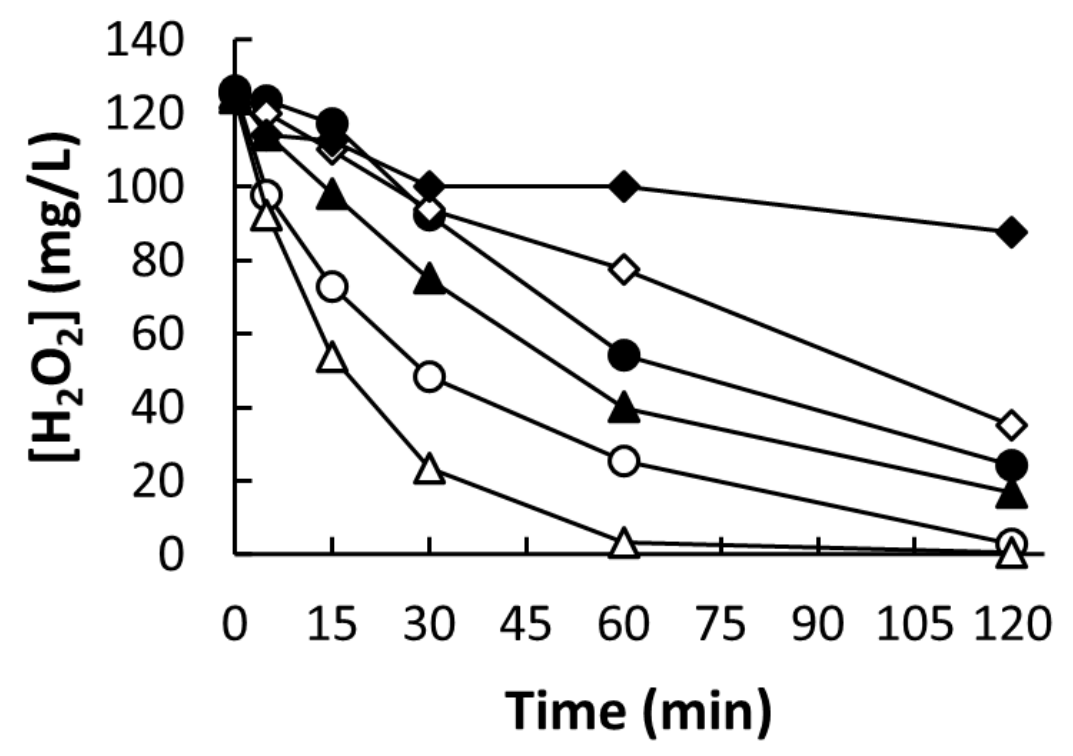

Figure 4.21. $\mathrm{H}_{2} \mathrm{O}_{2}$ consumption for the solar photo-Fenton process in the different studied water matrices.

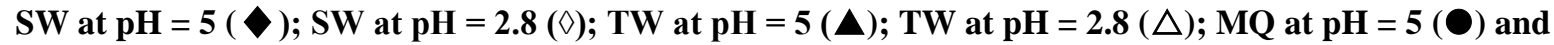
MQ at $\mathbf{p H}=\mathbf{2 . 8}(\circ)[137]$.

\subsubsection{Fluorescence spectroscopy analysis}

The removal of ENR should not be related straightforward with a detoxification of the solution, as other products (even more toxic than parent compounds) might be released into the solution. To evaluate the amount of organics in the solution, total organic carbon (TOC) was determined after $120 \mathrm{~min}$ of solar photo-Fenton in all three matrices at $\mathrm{pH}=2.8$ and 5.0. Interestingly, higher mineralization was reached for solar photo-Fenton at $\mathrm{pH}=2.8$ for both $\mathrm{MQ}$ and TW with values of ca. $80 \%$, followed by the same matrices at $\mathrm{pH}=5.0$ (mineralization slightly above 50\%), whereas for $\mathrm{SW}$, mineralization was below $20 \%$ at both pHs. Finally, in the case of the control of $\mathrm{H}_{2} \mathrm{O}_{2}$ 
with irradiation in MQ water, the observed ENR removal did not result in any mineralization.

The next step is gaining further insight into the nature of the organic matter present in the solution. However, for such complex samples conventional chromatography cannot be applied and gross parameters such as total organic carbon or COD provide scarce information. For this reason, EEMs were measured, as they can give the fingerprints of major chromophores present in the reaction mixture. Figure 4.22 shows the EEMs recorded for the photolysis, Fenton and solar photo-Fenton of ENR in MQ at $\mathrm{pH}=2.8$. It can be observed photolysis was not able to produce significant changes in EEMs, which could be attributed to the persistence of the FQ core. On the contrary, changes in the EEMs can been observed for (solar photo)-Fenton, being faster for solar photo-Fenton than for Fenton. It might involve that those processes are able to destroy the FQ moiety. 

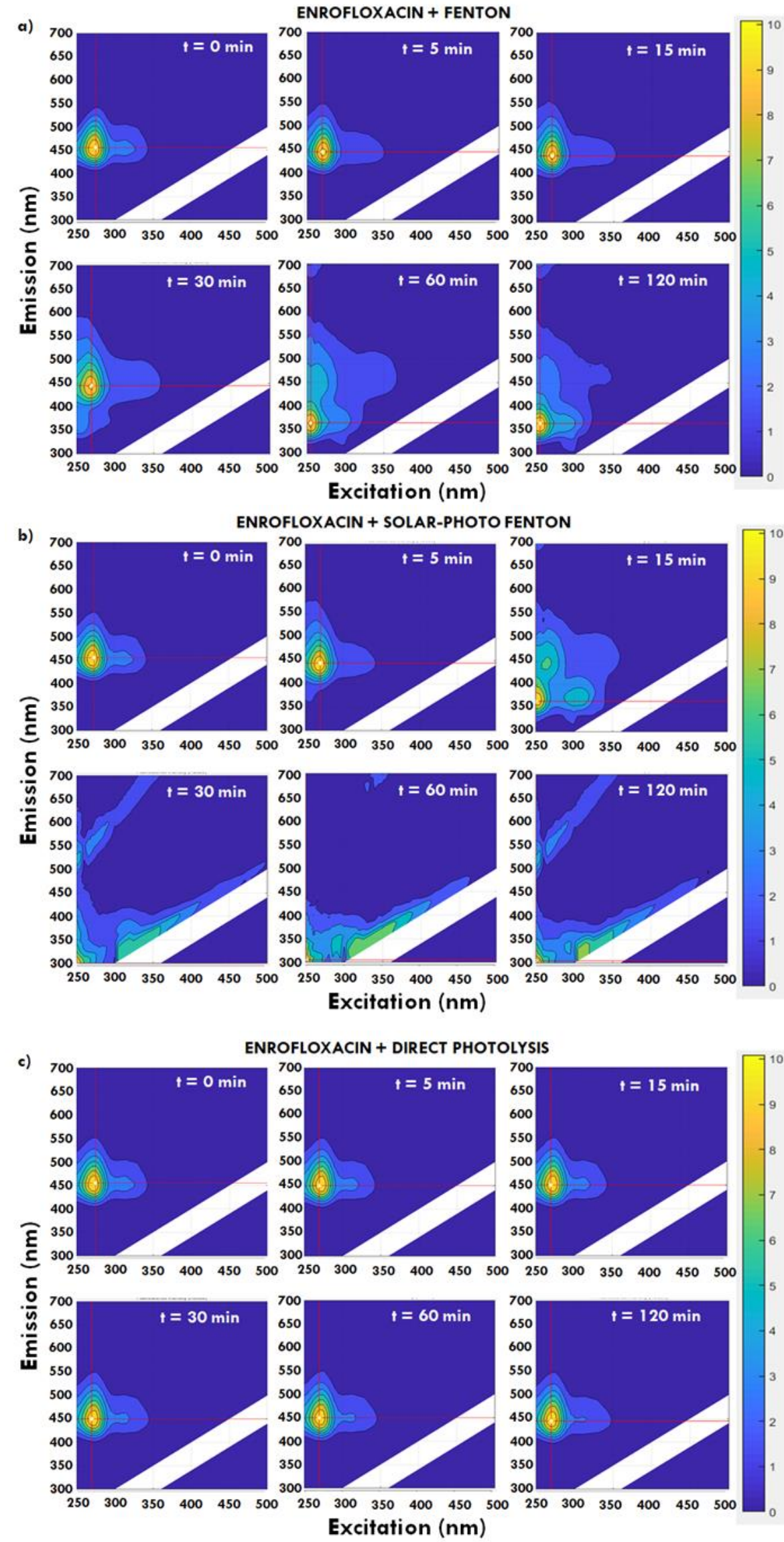
Figure 4.22. Normalized fluorescence excitation-emission matrices obtained at different stages of ENR degradation in $\mathrm{MQ}$ at initial $\mathrm{pH}=2.8(0,5,15,30,60$ and 120min) by: a) Fenton, b) solar photo-Fenton and c) direct photolysis [137].

In order to gain further insight into the behaviour of the FQs along the process, PARAFAC was applied to the data set containing all the measured EEMs obtained in this work, namely photolysis, Fenton and photo-Fenton, in all three water matrices and both $\mathrm{pH}$ values (see mathematical calculation section for details). A model consisting of 5 components was chosen, as in comparison with the models with fewer components, it was the only one able to resolve all the overlapped fluorescence signals appearing in the measured EEMs and, on the other hand, showed a higher chemical consistency when compared to those considering more components (Figure 4.23), that shows the CORCONDIA behaviour vs. the number of modelled components, were an abrupt change in the tendency of the curve was observed beyond the 5-model [147].

In Figure 4.24 the fingerprints for the 5-component model are shown. $\mathrm{C} 1$ can be related with the parent pollutant, ENR, although other by-products containing the FQ core can contribute. $\mathrm{C} 2$ presents very similar fingerprint as $\mathrm{C} 1$, but with a small shift in the maximum position to lower values in the emission axis; thus $\mathrm{C} 2$ is also supposed to belong to FQ type molecules. On the other hand, C3, C4 and C5 appear only in those experiments where the FQ structure is destroyed (Fenton and solar photo-Fenton, at pH $=2.8$ with MQ and TW), and hence, they should be associated to different families of by-products generated by the strong oxidation of FQ.

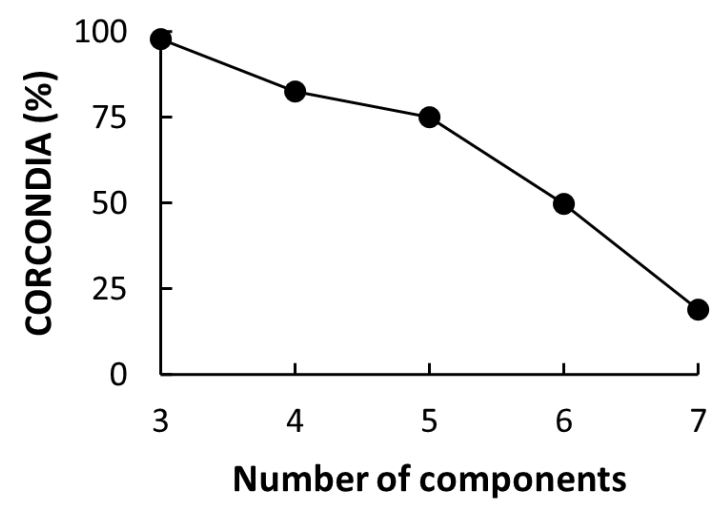

Figure 4.23. Obtained core consistency diagnostic values (expressed as percentage) for the different tested models [137]. 

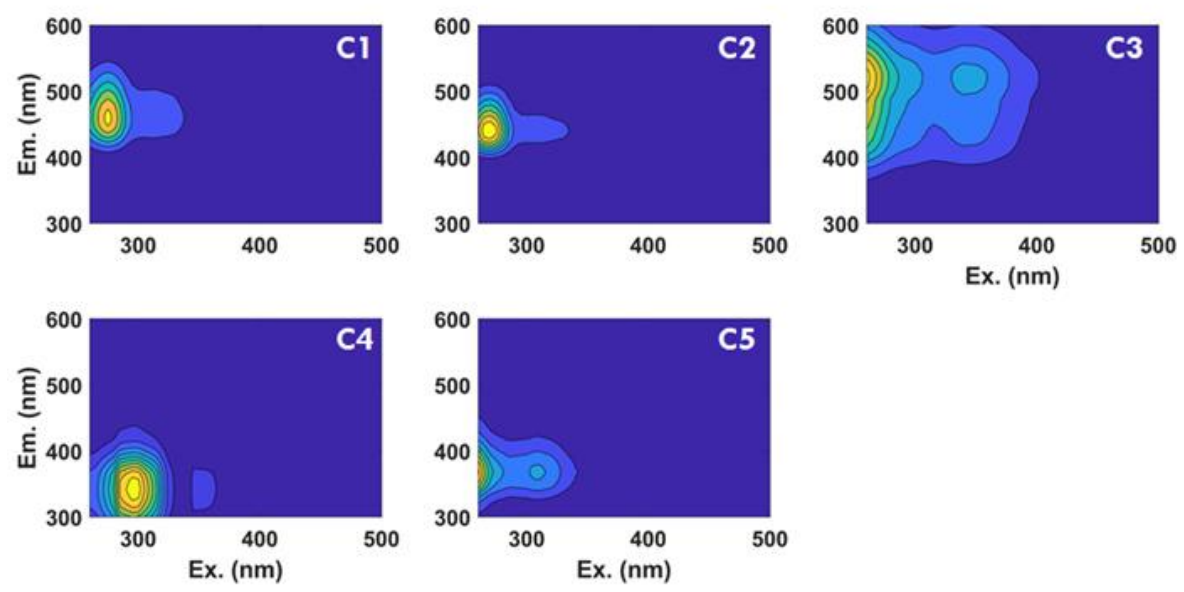

Figure 4.24. Fingerprints of the 5 components obtained after the mathematical treatment by PARAFAC of a set of 110 EEMs obtained along photolysis, Fenton and solar photo-Fenton in all three water matrices and at pH 2.8 and 5.0 [137].

Certainly, one of the most important subjects to be addressed is the removal of the FQ moiety, since the antibiotic properties could be associated to this functional group. Hence, the remaining amount of FQ might be considered as a preferred method to assess the efficiency of the photochemical process than just the disappearance of ENR followed by HPLC. As C1 and C2 are assigned to compounds with the FQ moiety, the sum of their scores could be associated with the remaining amount of FQ in the medium was plotted vs irradiation time (Figure 4.25).

Comparison of Figure 4.19 and Figure 4.25 shows that, in general, similar trends can be found between $\mathrm{C} 1+\mathrm{C} 2$ and ENR relative amount shown by HPLC: a) No destruction of the FQ in photolysis experiments, in line with the low removal of the parent pollutant; b) Some decrease in the $\mathrm{C} 1+\mathrm{C} 2$ components was reached in the other cases following the trend: Fenton at $\mathrm{pH}=5.0<$ photo-Fenton at $\mathrm{pH}=5.0=$ Fenton at $\mathrm{pH}=2.8<$ photo-Fenton at $\mathrm{pH}=2.8$. This behaviour can be understood by considering that although photolysis is able to remove ENR, it cannot produce important changes in the fluoroquinolone structure $[45,46,174]$ and only stronger oxidation agents (e.g. $\bullet \mathrm{OH})$ efficiently attack the fluoroquinolone core [180]. 


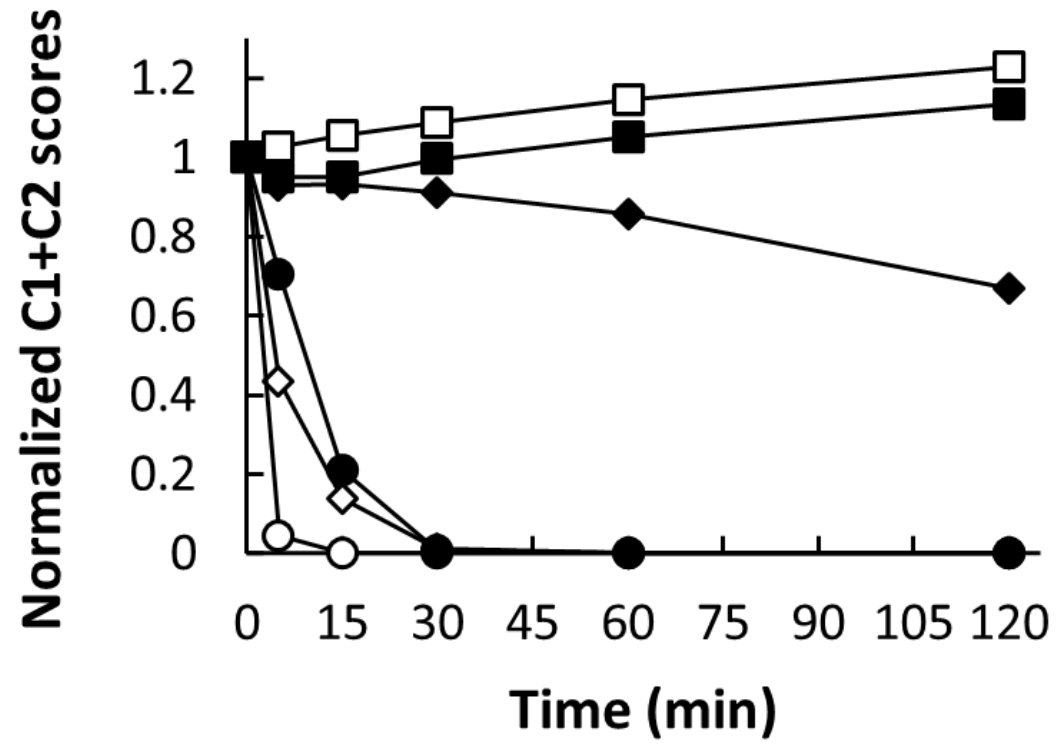

Figure 4.25. Plot of the flouroquinolonic components obtained in the EEM-PARAFAC model (C1 and C2) vs. time in MQ water. Photolysis at pH = $5(\square)$; photolysis at pH = $2.8(\square)$; Fenton at pH = $5(\checkmark)$; Fenton

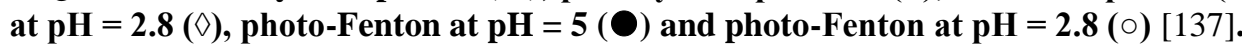

It is also interesting to test according to this parameter the effect of the water matrix. Results obtained for photo-Fenton can be observed in Figure 4.26. A comparison of Figures 2 and 6 shows significant differences, involving that the removal of ENR might not involve the elimination of the FQ moiety. Reactions carried out in SW resulted in a very fast removal of ENR but the presence of $\mathrm{C} 1$ and $\mathrm{C} 2$ after $120 \mathrm{~min}$, indicates that the reaction resulted in the release of by-products still having the FQ structure. On the contrary, in MQ and TW, important changes in the structure of the molecule have occurred and all the fluoroquinolonic intermediates were removed after $15 \mathrm{~min}$ at $\mathrm{pH}=2.8$ and at $30 \mathrm{~min}$ at $\mathrm{pH}=5.0$. This is in line with TOC measurements (where the lowest mineralization percentage was obtained in the case of SW at both studied pHs) and can be explained if (photo)-Fenton in the presence of high concentration of chlorides results in the formation of less reactive species, that can destroy ENR but not the FQ core. 


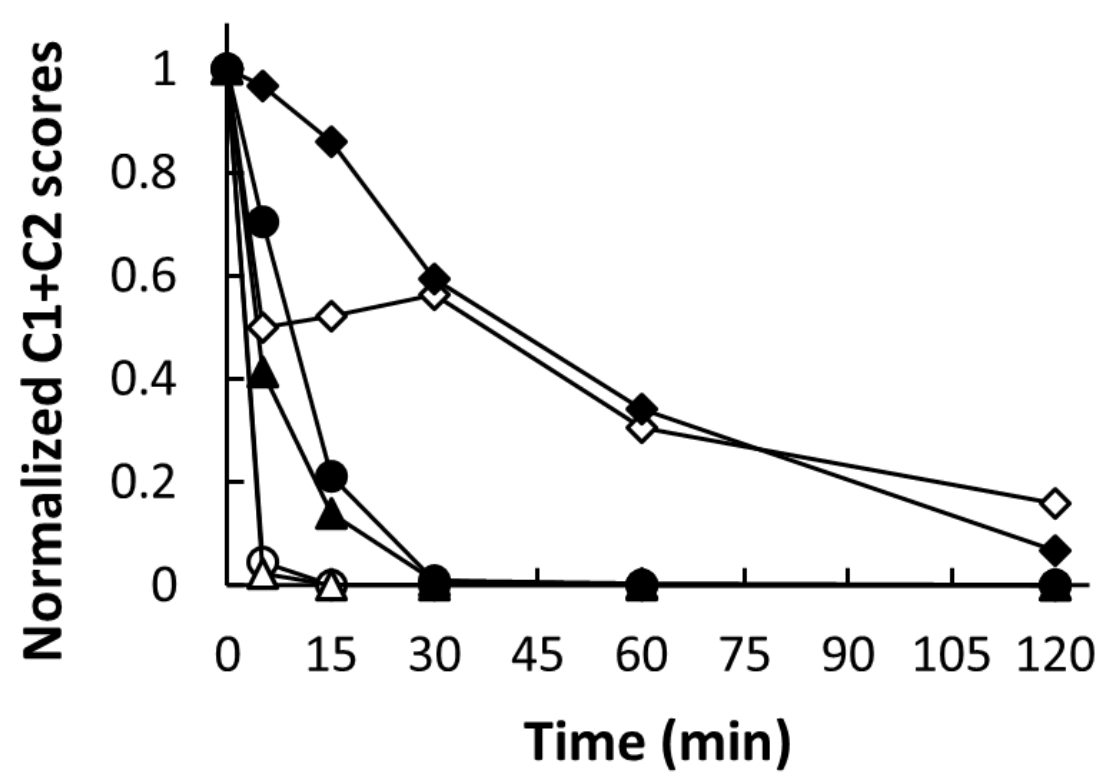

Figure 4.26. Elimination of flouroquinolonic components (C1 and C2) obtained in the EEM-PARAFAC model vs time with solar photo-Fenton at different water matrices. $\mathrm{SW}$ at $\mathbf{p H}=\mathbf{5}(\checkmark) ; \mathrm{SW}$ at $\mathbf{p H}=\mathbf{2 . 8}$

$(\diamond) ; \mathrm{TW}$ at $\mathbf{p H}=5(\Delta) ; \mathrm{TW}$ at $\mathbf{p H}=\mathbf{2 . 8}(\triangle) ; \mathrm{MQ}$ at $\mathbf{p H}=\mathbf{5}(\odot)$ and $\mathrm{MQ}$ at $\mathbf{p H}=\mathbf{2 . 8}(\circ)$ [137].

\subsubsection{Agar diffusion tests}

In order to check the residual antibiotic properties of the FQ treated solution, inhibition halo tests were performed. In line with expectations, these bioassays showed an almost identical behaviour as the fluoroquinolonic compounds, as shown by the $\mathrm{C} 1+\mathrm{C} 2$ components decay in EEM-PARAFAC. Figure 4.27 shows results in MQ water for photolysis and (photo)-Fenton at $\mathrm{pH}=2.8$ and 5.0. The inhibition halo disappeared after 15 and 30 min for solar photo-Fenton and Fenton processes respectively in MQ at $\mathrm{pH} 2.8$, whereas in photolysis the inhibition halo remained constant even after $120 \mathrm{~min}$ of irradiation and not notable decrease of inhibition halos for Fenton performed at $\mathrm{pH}$ 5.0 was seen. This might indicate that the destruction of the FQ structure is needed to eliminate the antibiotic properties [37,174,209].

The same trend can be found in the photo-Fenton treatment under different experimental conditions (Figure 4.28). The decay in the antibacterial activity is in agreement with the data obtained with the EEM-PARAFAC analysis of the FQ components: the degradation was faster at $\mathrm{pH}=2.8$ than at $\mathrm{pH}=5.0$ and the process driven at MQ water was more efficient than when salts were present.

Finally, to verify if the possible chlorinated by-products formed in SW matrices were even more toxic than the original ENR, additional Aliivibrio fischeri experiments were performed, showing also a decay of toxicity with the reaction time (approximately 
$50 \%$ decrease in the toxicity measured according to this assay after $120 \mathrm{~min}$ of photochemical process).

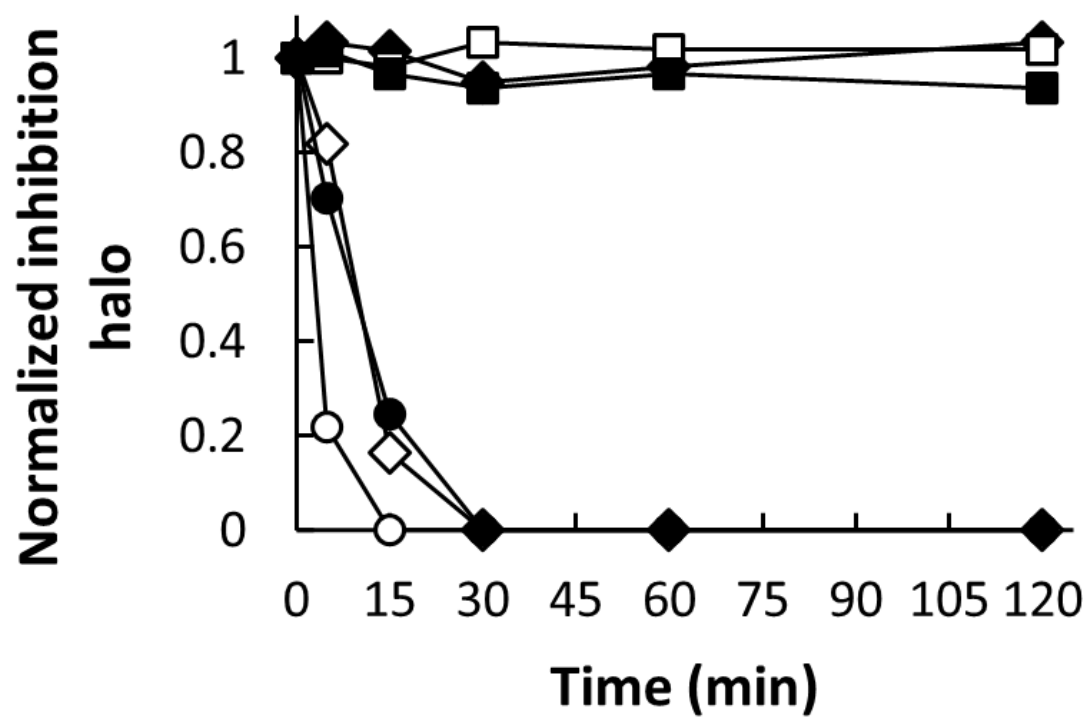

Figure 4.27. Antibacterial activity behaviour obtained with $E$. Coli for the different tested processes in MQ at both studied pHs. Photolysis at pH = $5(\square)$; photolysis at pH = $2.8(\square)$; Fenton at pH $=5(\diamond)$;

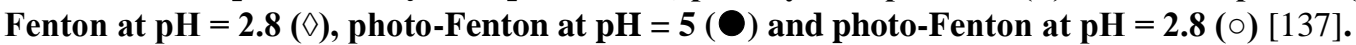

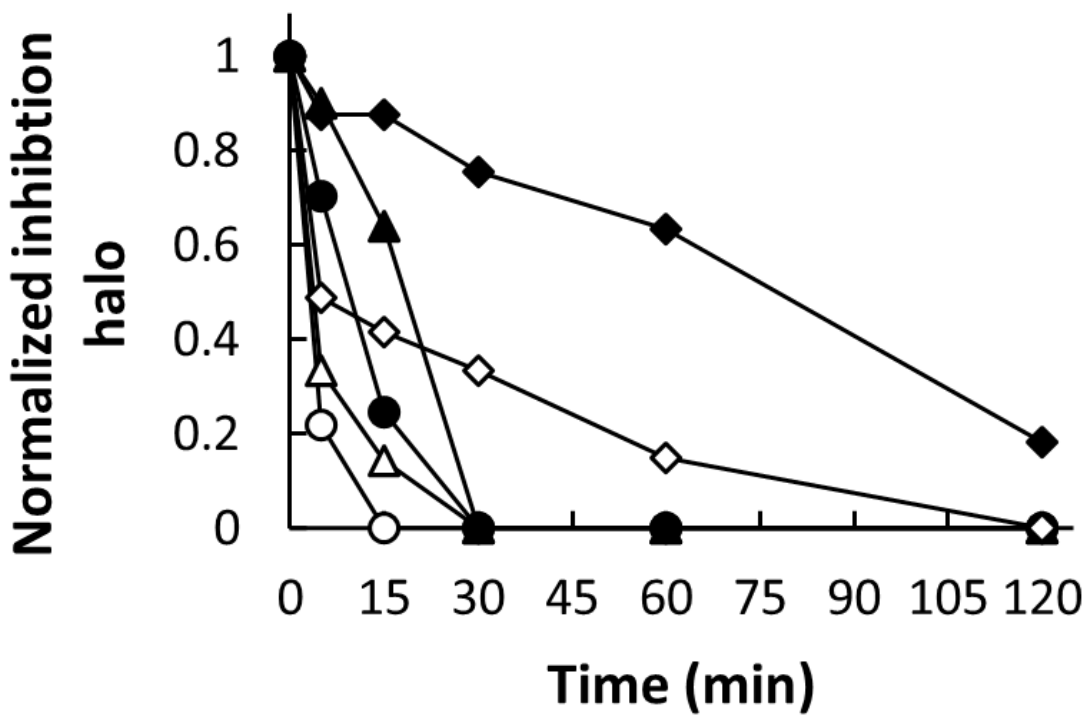

Figure 4.28. Antibacterial activity behaviour obtained with solar photo-Fenton within the different tested

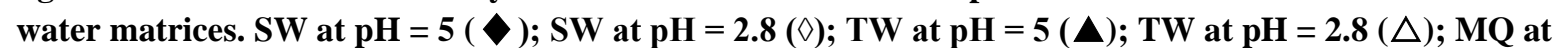
$\mathbf{p H}=\mathbf{5}(\bigcirc)$ and MQ at $\mathbf{p H}=\mathbf{2 . 8}(\circ)[137]$.

\subsubsection{Conclusions}

Solar photo-Fenton process resulted to be more efficient than photolysis and Fenton (according to ENR removal, mineralization percentage and inhibition halo 
decrease) Regarding the effect of the initial $\mathrm{pH}$, higher removals were obtained at $\mathrm{pH}$ 2.8 rather than at $\mathrm{pH}$ 5.0. However, the good performance of solar photo-Fenton at $\mathrm{pH}$ 5 , probably due to iron complexation, requires further research. Similar performances have been observed in MQ and TW, with fast total removal and high mineralization achieved in both cases. On the contrary, in SW, the fast ENR removal did not resulted in concomitant mineralization or destruction of the FQ core.

According to bioassays and EEM-PARAFAC results, photolysis of ENR does not result in destruction of the FQ core, therefore keeping its antibacterial activity. In contrast, (solar photo)-Fenton processes are able to destroy the FQ core, what results in a decrease of the inhibition halo.

Finally, EEM-PARAFAC study has demonstrated to be a simple methodology to provide supplementary information on the behaviour of organic matter and can be more easily correlated than HPLC analysis with changes in toxicity, and could be an alternative to sophisticated analytical technics when identification of reaction byproducts is not required.

\subsection{Fluorescence Spectroscopy and Chemometrics: a Simple and Easy Way for the Monitoring of Fluoroquinolone Mixtures Degradation}

This section shows the information from the publication referenced as [119]: Sciscenko, Iván; Thị Mỹ Hắng, Hoàng; Escudero-Oñate, Carlos; Oller, Isabel; Arques, Antonio. Fluorescence Spectroscopy and Chemometrics: A Simple and Easy Way for the Monitoring of Fluoroquinolone Mixture Degradation. ACS Omega 2021, 6, 4663-4671. https://doi.org/10.1021/acsomega.0c05370

\subsubsection{Introduction}

FQs are fluorescent molecules, thus being an advantage for their determination at low concentrations in complex samples [210]. However, without a separation method such as HPLC, when measuring a single emission fluorescence scan from a solution containing a mixture of these compounds, signals will likely overlap. In order to solve this problem, chemometric tools are required. In this sense, the PARAFAC analysis is one of the most employed within this area, being able to decompose the underlying signals from a fluorescence EEM dataset [117]. Nevertheless, as well as other chemometric applications, such as principal 
component analysis or artificial neural networks, PARAFAC requires a solid programming background, which might be its major drawback. Up to date, however, since EEM-PARAFAC usage is rapidly arising, free graphical user interfaces have been developed [122,123].

So far, EEM-PARAFAC has been mainly employed in the characterization of complex water samples containing natural dissolved organic matter [96,134], as well as monitoring the organic matter along a WWTP [124,126], and, more recently, has been also applied to CEC degradation studies $[135,136]$. In addition to this, it has also been previously employed in combination with routine HPLC analysis and different bioassays to get a better understanding of the transformation of a FQ, enrofloxacin, under different (photo)-oxidative conditions [137]. However, application of this methodology to more complex samples remains, as far as we know, unexplored. Analyzing changes within the fluorescence matrices, not only qualitatively, but measuring the different components (identified as original pollutants and reaction intermediates) in a mixture of three FQs is challenging, as it would confirm EEM- PARAFAC as a powerful tool to gain insight into the behavior of the sample, avoiding the use of expensive and sophisticated tools, not always available.

With this background, in this work, the degradation of three FQs with high occurrence in water bodies is reported. OFL, ENR and SAR will be simultaneously determined by timecourse EEM with the subsequent PARAFAC analysis. Treatment of the mixture by solar simulated photo-Fenton has been studied and compared with the corresponding controls: photolysis, $\mathrm{H}_{2} \mathrm{O}_{2} / \mathrm{h} v$ and Fenton $\left(\mathrm{Fe} / \mathrm{H}_{2} \mathrm{O}_{2}\right)$ [61]. The process will be also followed by the most commonly employed techniques: HPLC for pollutant removal, mineralization by total organic carbon (TOC), and antibacterial activity decay by the zone of inhibition halo test with Escherichia coli. Finally, possible correlations between the different information extracted from all the applied methodologies will also be investigated.

\subsubsection{Experimental}

\subsubsection{Reagents}

OFL, ENR and SAR (Table 1.1) high purity (>99\%) and catalase (lyophilized powder from bovine liver 2000-5000 units/mg protein) were purchased from Sigma-Aldrich. $\mathrm{Na}_{2} \mathrm{SO}_{3}$ anhydride (85-90\%), $\mathrm{FeSO}_{4} \cdot 7 \mathrm{H}_{2} \mathrm{O}, \mathrm{H}_{2} \mathrm{O}_{2}(33 \%$ w/v), ascorbic acid, 1,10-phenanthroline 1hydrate, $\mathrm{H}_{2} \mathrm{SO}_{4}(96 \% \mathrm{w} / \mathrm{w})$, and UHPLC grade methanol and acetonitrile, were obtained from AppliChem-Panreac. Formic acid (80\% w/w) was purchased from VWR Chemicals. Ultrapure water was prepared with a Merck Milli-Q system. Zone of inhibition tests were made 
using E. coli CECT 101 strain, employing tryptone soya and Müller-Hinton broth, both provided by Scharlau.

\subsubsection{Solar simulator photo-reactor}

Experiments were carried out in an open batch reactor (total volume $500 \mathrm{~mL}$ ), loaded with $250 \mathrm{~mL}$ of the FQ mixture, consisting of $8 \mathrm{mg} / \mathrm{L}$ of each compound, OFL, ENR and SAR. This concentration is above the values commonly found in ecosystems, but it allows a better monitoring of the process (e.g accurate kinetic data, reliable values of mineralization). Besides, AOP can be also used for the concentrate stream treatment after membrane processes, where high concentration of CEC are expected [172].

Irradiations were performed with a solar simulator Oriel Instrument, equipped with a high-pressure Xe lamp (Ushio UXL-302-0). The initial $\mathrm{pH}$ of the solutions was adjusted to 2.8, 5.0 and 7.0 by dropwise addition of $\mathrm{H}_{2} \mathrm{SO}_{4} 0.5 \mathrm{M}$ and/or $\mathrm{NaOH} 1 \mathrm{M}$. When required, $125 \mathrm{mg} / \mathrm{L}$ of $\mathrm{H}_{2} \mathrm{O}_{2}$ was added, which accounts for the total stoichiometric amount needed to mineralize the three FQs, to prevent exhaustion of this reagent during the reaction. For the (photo)-Fenton experiments, $5 \mathrm{mg} / \mathrm{L} \mathrm{Fe}(\mathrm{II})$, as $\mathrm{FeSO}_{4} \cdot 7 \mathrm{H}_{2} \mathrm{O}$ salt, were added to the reactor. All the assays were carried out for $120 \mathrm{~min}$, taking samples in time-intervals and processed differently depending on the type of analysis, as described in "Sample Preparation" section.

FQ mixture solution has proved to be stable in the dark under each of the studied $\mathrm{pH}$ values, and the addition of $\mathrm{H}_{2} \mathrm{O}_{2}$ did not produce further degradation. Comprehensively, the $\mathrm{Fe}(\mathrm{II}) / \mathrm{H}_{2} \mathrm{O}_{2}$ system in dark conditions (Fenton reaction) produced considerable FQ degradation, as described in "Results and Discussion" section.

\subsubsection{Sample preparation}

For HPLC and EEM measurements, all samples contained $\mathrm{H}_{2} \mathrm{SO}_{4} 5.0 \mathrm{mM}$ (to provide an acidic media for all the analysis) and methanol $0.25 \mathrm{M}$ to quench the excess of $\mathrm{H}_{2} \mathrm{O}_{2}$ and ensure that the Fenton reaction has stopped [211]. For total organic carbon (TOC) determinations, an excess of $\mathrm{Na}_{2} \mathrm{SO}_{3}$ was used to get rid of the hydrogen peroxide in order to avoid interferences caused by the addition of extra organic substances. In antibacterial activity assays, all samples were firstly adjusted to $\mathrm{pH} 7.0$ with $\mathrm{NaOH} 1$ $\mathrm{M}$, and afterwards, an excess of catalase enzyme was added to eliminate the remaining $\mathrm{H}_{2} \mathrm{O}_{2}$. 


\subsubsection{Chemical and toxicological determinations}

The removal of OFL, ENR and SAR was determined by HPLC analysis using a Hitachi Chromaster apparatus with a UV/Vis detector. A C18 Machery-Nagel column Nucleodur- $\pi^{2} 5$ $\mu \mathrm{m}$ was used as stationary phase, and an isocratic flow of $0.25 \mathrm{~mL} / \mathrm{min}$ of formic acid $0.1 \mathrm{M}$ $80 \%$ and acetonitrile $20 \%$ was used as eluent. The column oven was set at $40^{\circ} \mathrm{C}$ and the detection was performed at $285 \mathrm{~nm}$. Mineralization measurements were performed in a Shimadzu TOC-V equipment with ASI-V autosampler. Fluorescence was measured in a Horiba PTI Quanta Master 400 spectrofluorometer, equipped with a Xe arc lamp. EEMs were recorded within an excitation range of 250-500 nm, and 300-650 $\mathrm{nm}$ of emission range (both recorded within $5 \mathrm{~nm}$ intervals). Inner filter effect corrections $(250-650 \mathrm{~nm})$ were performed with a Hitachi-UH5300 spectrophotometer. The same device was used to measure the dissolved Fe(II) and total iron according to the ISO 6332:1988 standardized method with the 1,10phenanthroline reagent. Antibacterial activity assays were performed employing E. coli bacteria, which was previously grown up in a nutrient media for $18 \mathrm{~h}$. The colonies were inoculated in a tryptone soya broth, having a suspension of 0.5 units in McFarland scale. A sterile cotton swab was used to pick bacterial suspension and spread it on the surface of the Mueller-Hinton agar in the Petri dish. Then, $0.85 \mathrm{~cm}$ wells were made and filled with $100 \mu \mathrm{L}$ of the sample. Finally, Petri dishes were incubated at $37^{\circ} \mathrm{C}$ for $24 \mathrm{~h}$ before measuring the zone of inhibition diameters.

\subsubsection{PARAFAC analysis}

PARAFAC analysis was performed employing MATLAB2018b with the free graphical user interface EEMlab [122]. When needed, samples were previously diluted accordingly, being the initial samples always diluted 1:20, and diminishing this factor proportionally with degradation time. The analyzed dataset consisted of 118 absorbance spectra and EEM, respectively, (including also the ones belonging to the individual FQs, as shown in Figure 4.32A) plus 14 blanks. Intensity standardization was carried out using water Raman scatter peak at $350 \mathrm{~nm}$ excitation wavelength, thus being also added to the dataset 14 water Raman scans [146].

During pre-processing stage, EEM with negligible fluorescence signals were treated as outliers, thus being eliminated. First order Rayleigh scatter band was corrected with missing values, and second order Rayleigh and both Raman scatter bands were handled by interpolation. EEM were always normalized previous to any PARAFAC analysis so that all 
samples contained similar weighting. Once the best model was chosen, normalization was reversed.

The number of components (underlying fluorophores) was assessed according to the chemical consistency of the obtained data, residuals distribution and the core consistency diagnostic (CORCONDIA)[147] (see Table 4.4 and Table 4.3).

Table 4.3. Core Consistency Diagnostic (CORCONDIA) values for the different tested PARAFAC models [119].

\begin{tabular}{|c|c|}
\hline Number of components & CORCONDIA (\%) \\
\hline 3 & 89 \\
\hline 4 & 49 \\
\hline 5 & 41 \\
\hline 6 & 5.4 \\
\hline
\end{tabular}

Table 4.4. Model residuals distribution [119].

\begin{tabular}{|c|c|c|c|}
\hline Sample & Measured EEM & Modelled EEM & Residual \\
\hline \multicolumn{4}{|l|}{ OFL } \\
\hline \multicolumn{4}{|l|}{ ENR } \\
\hline \multicolumn{4}{|l|}{ SAR } \\
\hline \multicolumn{4}{|l|}{ OFL+ENR+SAR } \\
\hline \multicolumn{4}{|l|}{$\begin{array}{c}\text { Photo-Fenton, pH } 2.8 \\
t=30 \mathrm{~min}\end{array}$} \\
\hline \multicolumn{4}{|l|}{$\begin{array}{c}\mathrm{H}_{2} \mathrm{O}_{2} / \mathrm{hv}, \mathrm{pH} 7.0 \\
t=60 \mathrm{~min}\end{array}$} \\
\hline $\begin{array}{c}\text { Photolysis, pH } 7.0 \\
t=120 \mathrm{~min}\end{array}$ & & & \\
\hline
\end{tabular}

\subsubsection{Results and discussion}

\subsubsection{Photolysis with and without $\mathrm{H}_{2} \mathrm{O}_{2}$ addition}

A first series of experiments were devoted to check the stability of FQs versus photolysis with simulated sunlight at different $\mathrm{pH}$ values, 2.8, 5.0 and 7.0 (Figure 4.29A-C, respectively). Noticeable antibiotic removal was observed, following the trend ENR > SAR > OFL, in agreement with other works [178,209]; this might be ruled by the presence of electron-donating groups in meta position respect the fluoride, which, in this case, only OFL has it (see Table 
1.1) [44]. Besides, the highest removals were obtained at $\mathrm{pH} 7.0$, evidencing the fact that FQ photolysis rates are not only structure-dependent, but $\mathrm{pH}$-dependent as well. Since at $\mathrm{pH}=7.0$ the neutral/zwitterionic ionization form of the FQs are predominating according to pKa given in Table 1.1, these species suffer faster photolysis than the cationic form that can be found at $\mathrm{pH} 2.8$ or 5.0, which is in line with other works reporting higher photolytic quantum yields for FQ neutral forms than the cationic ones $[45,179]$.
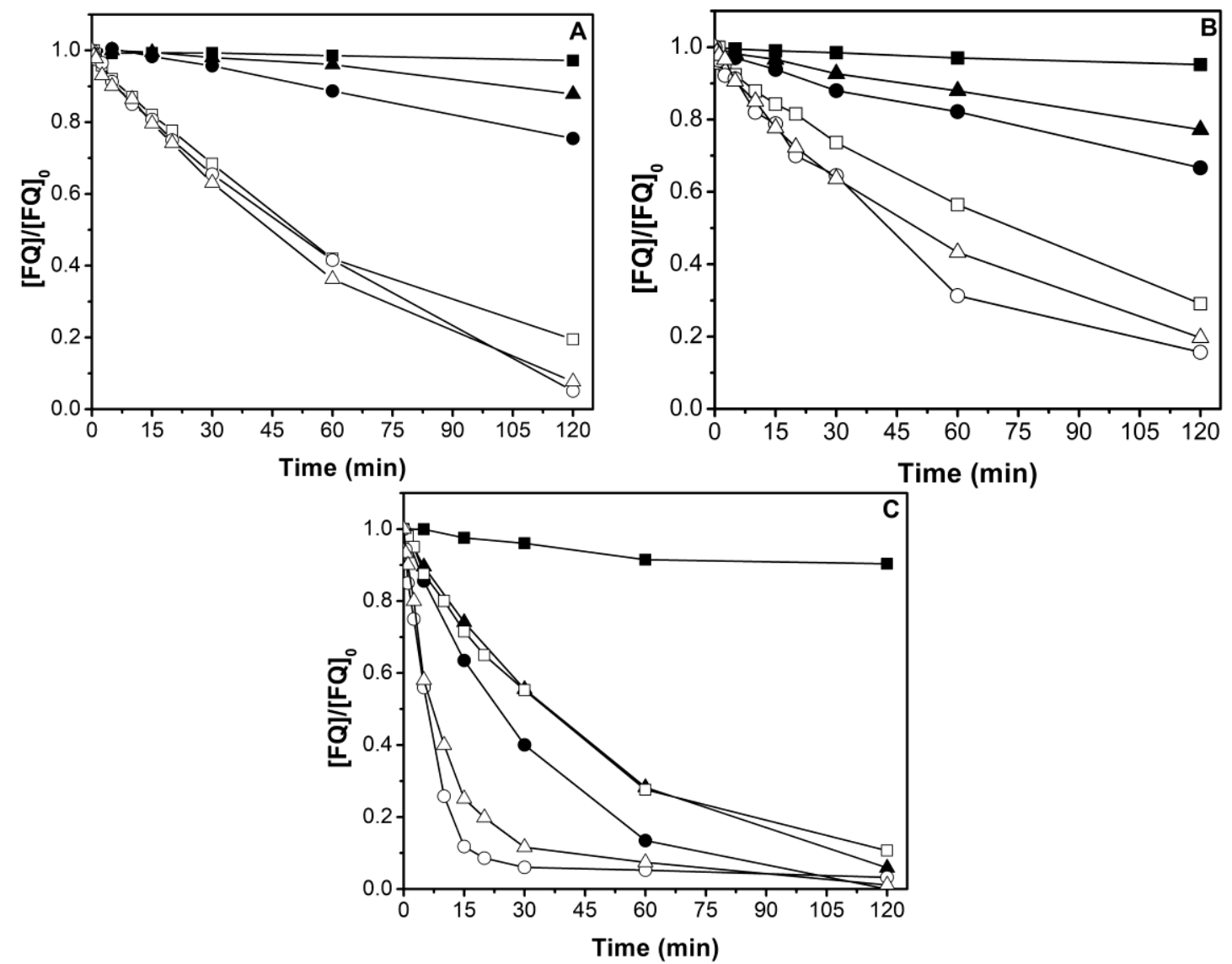

Figure 4.29. Degradation kinetics of the three studied FQs $(8 \mathrm{mg} / \mathrm{L}$ each) under simulated sunlight irradiation (hv) and also with the addition of $\mathrm{H}_{2} \mathrm{O}_{2} 125 \mathrm{mg} / \mathrm{L}\left(\mathrm{H}_{2} \mathrm{O}_{2} / \mathrm{hv}\right)$ at initial pH: A) 2.8, B) 5.0 and C)

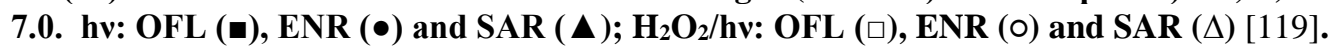

When $\mathrm{H}_{2} \mathrm{O}_{2} 125 \mathrm{mg} / \mathrm{L}$ was added into the system with sunlight irradiation, it enhanced FQs degradation in all cases. At pH 2.8 (Figure 4.29A), OFL, ENR and SAR, reached the 50\% degradation in ca. $45 \mathrm{~min}$, whereas in the analogous case without the $\mathrm{H}_{2} \mathrm{O}_{2}$ addition, the removal percentage obtained at that time was lower than $10 \%$. Therefore, two issues are relevant: 1) faster removals are related to the effect of higher ${ }^{\bullet} \mathrm{OH}$ concentration produced in situ by $\mathrm{H}_{2} \mathrm{O}_{2}$ dissociation from photon absorption within the UV region of the Xe emission spectra [212], and 2) since bimolecular kinetic constants rates between ${ }^{\bullet} \mathrm{OH}$ and $\mathrm{OFL}$ are comparable to the other FQs (at pH 7.0, $9 \pm 2 \times 10^{9} \mathrm{M}^{-1} \mathrm{~s}^{-1}$ for OFL, $10 \pm 3 \times 10^{9} \mathrm{M}^{-1} \mathrm{~s}^{-1}$ for ENR and $12 \pm 3 \times 10^{9} \mathrm{M}^{-1} \mathrm{~s}^{-1}$ for SAR) [209], there are no significant differences between OFL and 
ENR or SAR, contrarily to what was observed with light irradiation alone. A comparable trend was obtained at pH 5.0 (Figure 4.29B).

On the other hand, at pH 7.0, OFL showed again higher stability than ENR and SAR (Figure 4.29C), most probably due to the high contribution of photolysis process at this $\mathrm{pH}$, and where, as stated above, OFL showed a more refractory behaviour than the other two FQs.

\subsubsection{Fenton and photo-Fenton treatments}

Dark Fenton at pH 2.8 was able to remove the FQs in only 20 min (Figure 4.30A). As expected, a decrease in the reaction efficiency was observed with increasing $\mathrm{pH}$ value: at $\mathrm{pH}=$ 5.0 ca. 2 hours were required for the elimination of the FQs, while at $\mathrm{pH}=7.0$ the removal was scarce (Figure 4.30B-C). In general, changes in the reactivity of the different pollutants were negligible, attributable to the similar kinetic rate constants of ${ }^{\bullet} \mathrm{OH}$ with the three $\mathrm{FQs}$ mentioned in the previous section.

The irradiation with simulated sunlight resulted in an enhancement of the process (photoFenton). At $\mathrm{pH}=2.8$, the FQs were eliminated only in $5 \mathrm{~min}$. Interestingly, the reaction was still very fast at $\mathrm{pH}=5.0$, as observed previously for the ENR alone [137]. This is a very important result in views of a real implementation of the process, as strong acidification of the solution can be overcome without the need of adding extra chemicals, such as iron-chelating agents $[90,96]$. This result is attributable to the ability of FQs to form stable complexes (formation constant rate between 45-50 with a stoichiometry 3:1 FQ:Fe(III) [169]) which are able to extend a photo-Fenton-like process to higher $\mathrm{pH}$ domains [137], even until neutral $\mathrm{pH}$ (see Table 4.5). In sharp contrast with $\mathrm{pH} 5.0$, as it can be observed by comparing Figure 4.29C and Figure 4.30C, at $\mathrm{pH}=7.0 \mathrm{Fe}(\mathrm{II}) / \mathrm{H}_{2} \mathrm{O}_{2} / \mathrm{h} v$ was less efficient than $\mathrm{H}_{2} \mathrm{O}_{2} / \mathrm{h}$. This means that, firstly, even though there is significant iron in aqueous solution, photo-Fenton seems to be no longer efficient at this $\mathrm{pH}$, and, on the other hand, that FQ-iron complex might be more stable against photolysis than the antibiotic itself, as it has been reported for other FQ-metal complexes $[155,157]$. Due to these statements, the photodegradation contribution to their overall removal is, therefore, lower, thus explaining the faster removals obtained in the case without iron.

Table 4.5. Total iron and $\mathrm{pH}$ values changes after photo-Fenton processes [119].

\begin{tabular}{|cccc|}
\hline $\mathbf{p H}_{\mathbf{0}}$ & {$[\text { Fe tot }]_{\mathbf{0}}(\mathbf{m g} / \mathbf{L})$} & {$[\text { Fe tot }]_{120}(\mathbf{m g} / \mathbf{L})$} & $\mathbf{p H}_{\mathbf{1 2 0}}$ \\
\hline $\mathbf{2 . 8}$ & 4.9 & 4.8 & 2.8 \\
\hline $\mathbf{5 . 0}$ & 5.0 & 4.0 & 4.0 \\
\hline $\mathbf{7 . 0}$ & 4.7 & 2.6 & 5.5 \\
\hline
\end{tabular}



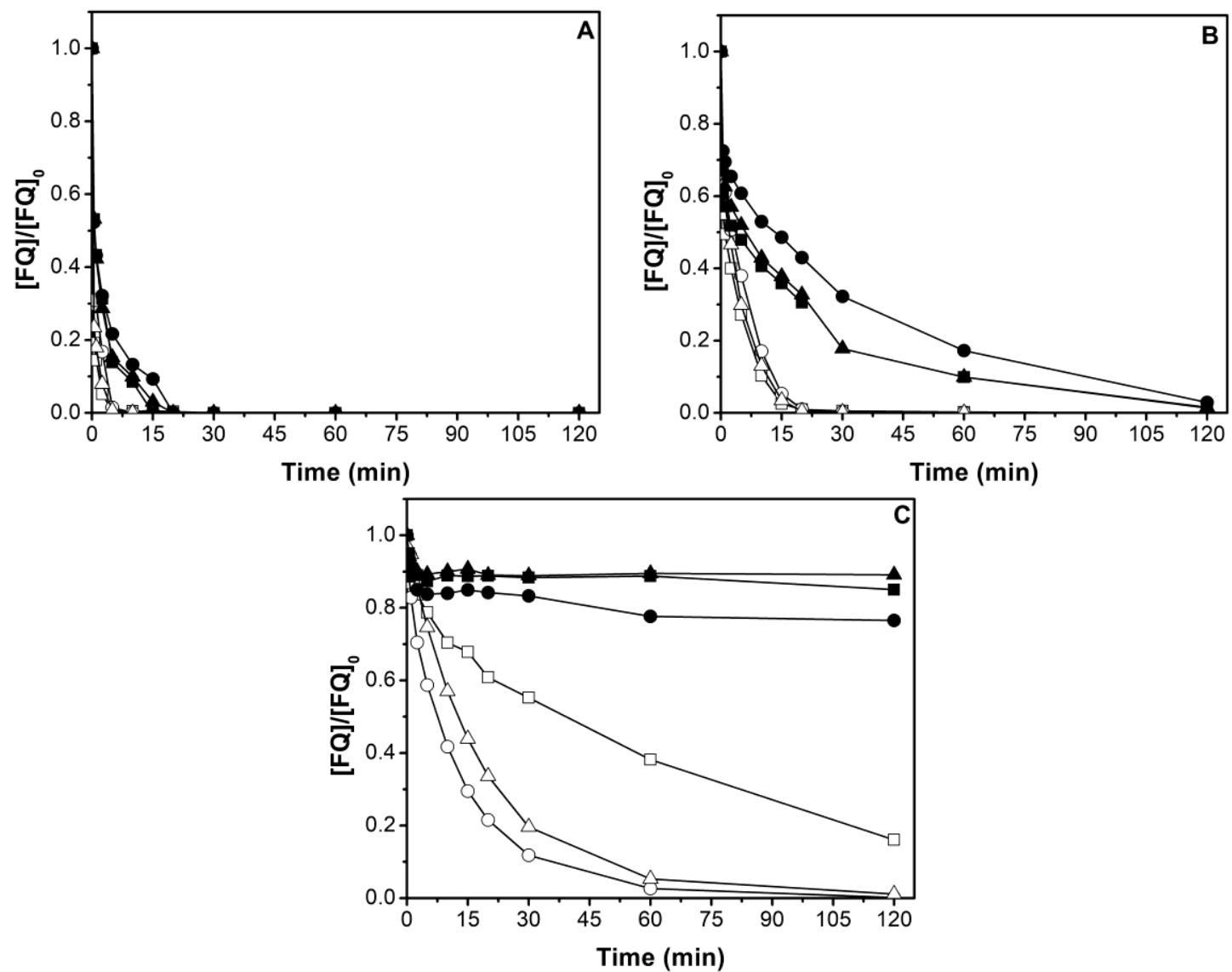

Figure 4.30. (Photo)-Fenton degradation kinetics for the three studied FQs $(8 \mathrm{mg} / \mathrm{L}$ each) at initial pH: A)

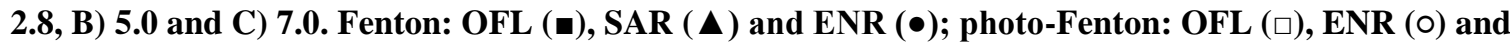
SAR $(\Delta)[119]$.

\subsubsection{EEM-PARAFAC analysis}

\subsection{The PARAFAC model}

Although FQs were degraded by most of the studied processes and experimental conditions, only with photo-Fenton at acidic $\mathrm{pH}$, significant mineralization was evidenced. Under these conditions, after $2 \mathrm{~h}, 77 \%$ and $62 \%$ TOC decrease was achieved at $\mathrm{pH} 2.8$ and 5.0, respectively, being negligible in all the other cases (Figure 4.31). These results are indicative of a large formation of transformation products along with the oxidative reaction. In order to analyse the FQ degradation and their by-product formation in an innovative and cheaper way, EEM were measured and then processed with PARAFAC, decomposing each fluorescence matrix into its individual components. This procedure has been already tested to investigate the degradation of ENR alone, but the system here investigated is more complex, since involves a mixture of three parent compounds with very similar molecular structures. 


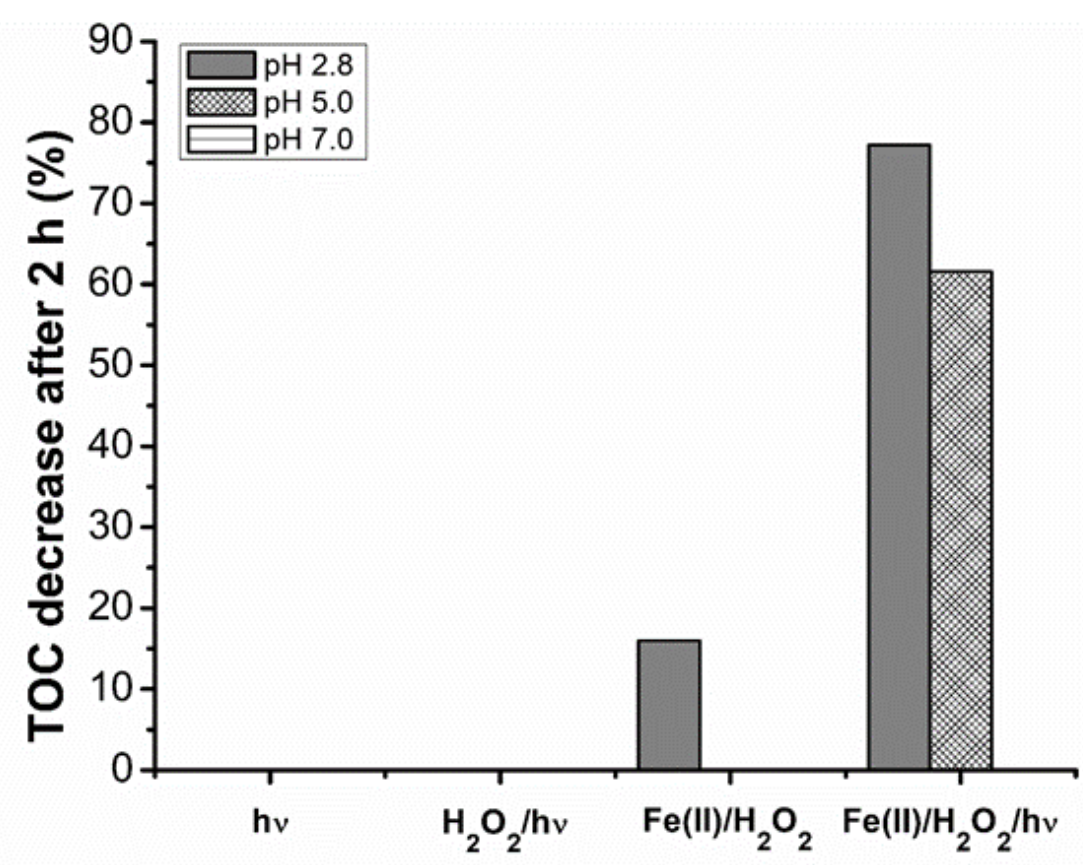

Figure 4.31. Mineralization percentages for the different studied AOPs over the FQ mixture, OFL, ENR and SAR $\left(8 \mathrm{mg} / \mathrm{L}\right.$ each) at initial $\mathrm{pH}$ values $2.8,5.0$ and 7.0. Where indicated, $\left[\mathrm{H}_{2} \mathrm{O}_{2}\right]_{0}=125 \mathrm{mg} / \mathrm{L}$ and $[\mathrm{Fe}(\mathrm{II})]_{0}=5 \mathrm{mg} / \mathrm{L}[119]$.

A set of 118 EEMs were considered in this study, obtained from the sampling at different times during the tested AOPs. As described in the Experimental Section, a model consisting of 5 components was chosen. Figure 4.32A shows the EEM from the individual FQs together with their mixture, and in Figure 4.32B the modelled fingerprints obtained from the PARAFAC model are shown.

The first three components of the model $(\mathrm{C} 1-3)$ can be associated with the parent pollutants, OFL, ENR and SAR, respectively, although the contribution of some by-products with similar structure cannot be disregarded. Component $\mathrm{C} 4$ exhibited shifts towards shorter excitation wavelengths $(<250 \mathrm{~nm})$, but remained close to the FQs emission range, ca. $480 \mathrm{~nm}$. On the other hand, C5 showed a big emission shift close to $390 \mathrm{~nm}$, which can be associated to deeper changes in the molecule than $\mathrm{C} 4$, such as cleavage of their piperazine side chain as it is the group which mainly modulates the FQs fluorescence spectra $[44,213]$. 

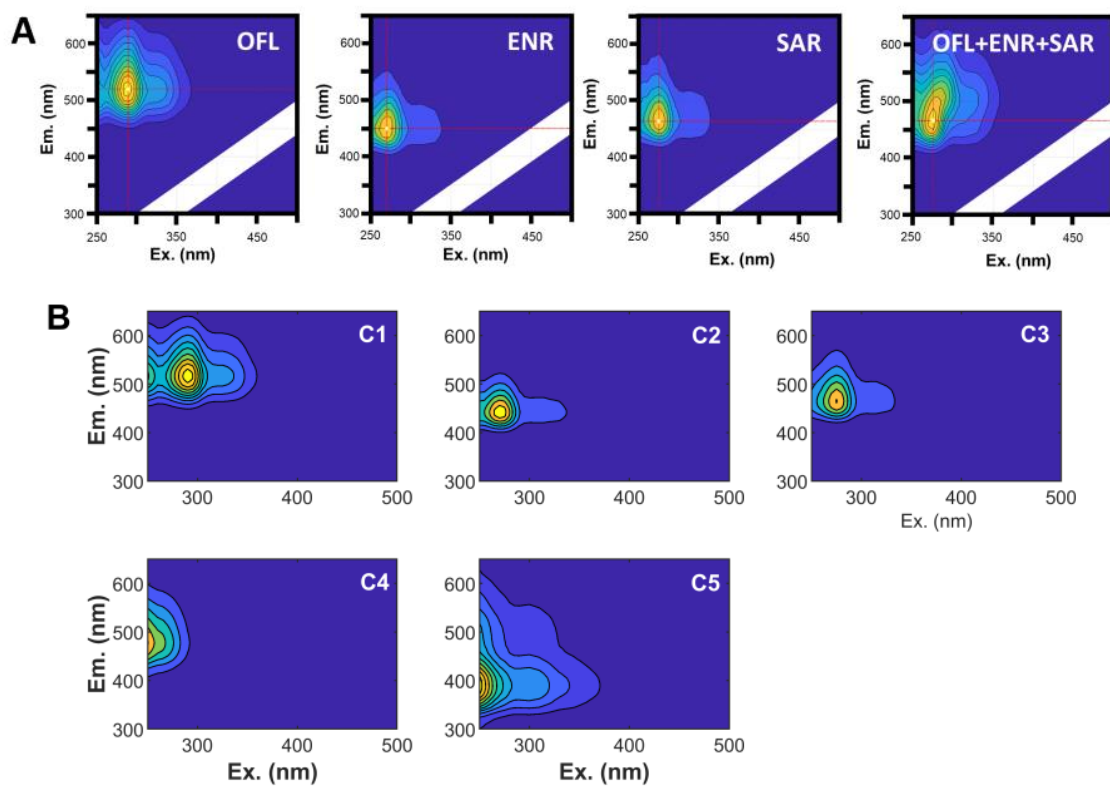

Figure 4.32. A) Normalized EEMs after their preprocessing with EEMlab, and B) 5-component fingerprints from the EEM-PARAFAC analysis [119].

\subsection{PARAFAC components evolution after $h v$ and $\mathrm{H}_{2} \mathrm{O}_{2} / h v$}

Based on EEM-PARAFAC analysis, the variation of each component was followed. At pH 2.8 and 5.0 a negligible decrease in $\mathrm{C} 1$ and $\mathrm{C} 3$ score values was observed. However, some increase in C2 was recorded, most probably associated with components with similar EEM as ENR but with higher fluorescence quantum yield that cannot be resolved by the model (Figure 4.33A-B). On the contrary, at $\mathrm{pH}=7.0$, decrease in $\mathrm{C} 1$ and $\mathrm{C} 2$ was monitored with an increase in C3 (Figure 4.33C). In this case, destruction of C1 and C2 structures and concomitant release of new photoproducts have to be hypothesized; a tentative explanation could be that the photoproducts formed from OFL, ENR and SAR degradations, should emit within the region of C3. C4 and C5 score values were negligible in all cases, indicating that photolysis resulted in scarce modification of the FQ molecule. These observations show that, in agreement with HPLC results, not only FQs photolytic kinetics are $\mathrm{pH}$-dependent, but also their photodegradation pathways.

When $\mathrm{H}_{2} \mathrm{O}_{2}$ was added under irradiation, the sample fluorescence exhibited a faster decay (Figure 4.33D-F). Also, in this case, significant differences were observed between $\mathrm{pH} 7.0$ and acidic conditions. Analyzing the components related to the parent pollutants, at $\mathrm{pH} 2.8$ and 5.0, $\mathrm{C} 1$ and $\mathrm{C} 2$ presented similar score values decay, whereas the faster ones were obtained for $\mathrm{C} 3$, those fitting with SAR's EEM. On the contrary, at pH 7.0, removals followed the same trend than the one obtained with HPLC measurements shown in Figure 4.30C (ENR > SAR > OFL), thus being $\mathrm{C} 2>\mathrm{C} 3>\mathrm{C} 1$. $\mathrm{C} 4$ formation was higher than without $\mathrm{H}_{2} \mathrm{O}_{2}$ addition, which proves 
a stronger attack to the FQ structure due to the higher photogenerated ${ }^{\bullet} \mathrm{OH}$, being its score values growth faster at neutral $\mathrm{pH}$, in line with the faster decrease of $\mathrm{C} 1-\mathrm{C} 3$.
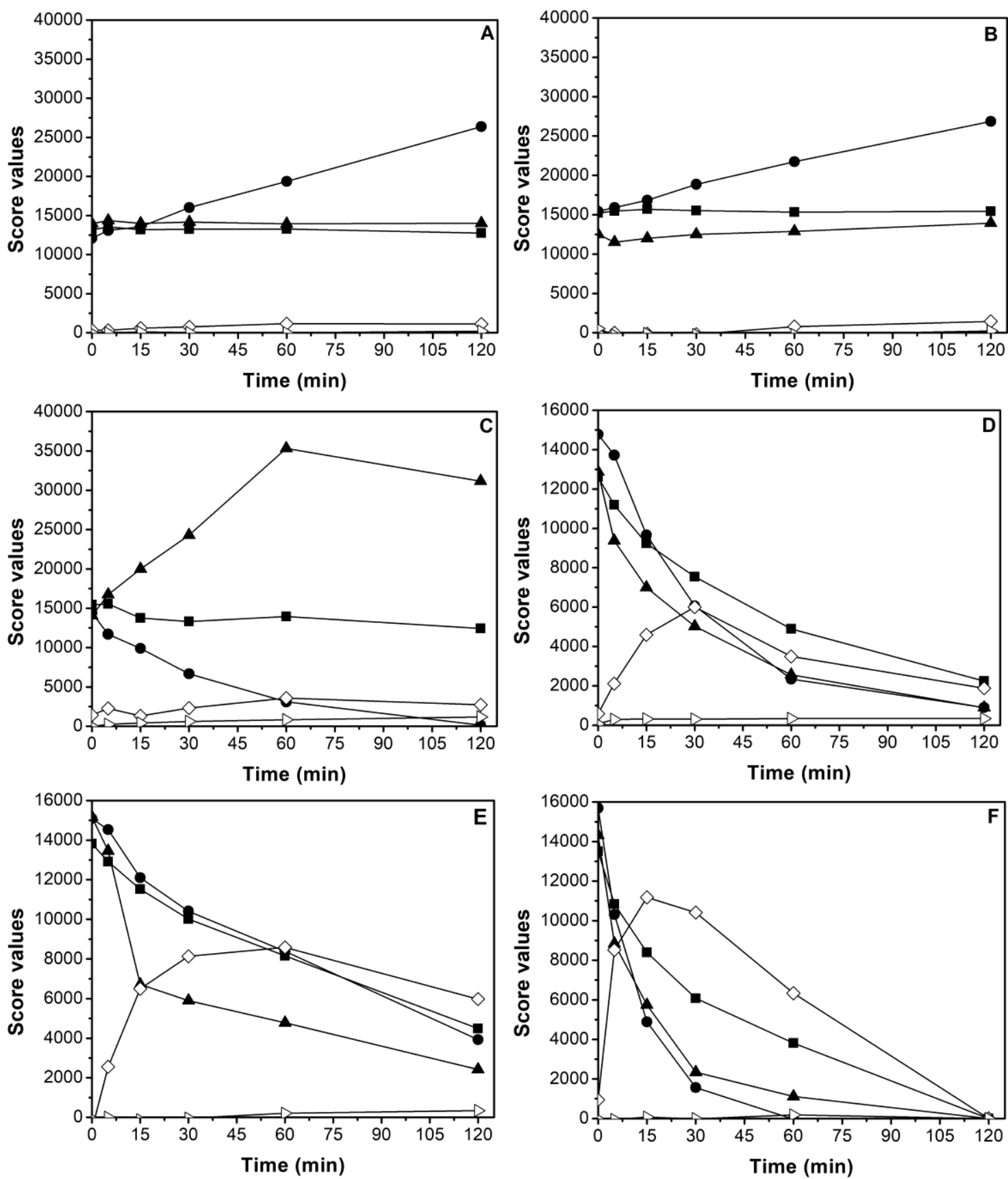

Figure 4.33. OFL, ENR and SAR $(8 \mathrm{mg} / \mathrm{L}$ each) degradation with light irradiation followed with EEMPARAFAC (5-component model) methodology at $\mathrm{pH}$ A) 2.8 , B) 5.0 and C) 7.0 , and with $\mathrm{H}_{2} \mathrm{O}_{2} 125 \mathrm{mg} / \mathrm{L}$ addition at pH D) 2.8, E) 5.0 and F) 7.0. PARAFAC component representation: $\mathrm{C1}(\bullet), \mathrm{C2}(\bullet), \mathrm{C3}(\triangle)$, C4 $(\diamond)$ and C5 $(\triangleright)[119]$.

\subsection{PARAFAC components evolution after Fenton and photo-Fenton} treatments

Analyzing PARAFAC score values behaviour after Fenton and photo-Fenton (Figure 4.34), C1-3 presented slower removal kinetics than the ones observed for OFL, ENR and SAR 
with HPLC-UV/Vis (Figure 4.30). For instance, at pH 2.8, C1-3 disappeared after ca. 15 min, whereas the parent pollutants were degraded in only $5 \mathrm{~min}$. This confirms that products with similar fingerprints as OFL, ENR and SAR are included in C1-C3 components, as they cannot be completely resolved by the model. As expected, PARAFAC components exhibited a faster decay at pH 2.8, followed by 5.0 and 7.0, respectively, for Fenton and photo-Fenton. In line with the mineralization results (Figure 4.31), only for Fenton at $\mathrm{pH} 2.8$, and photo-Fenton at $\mathrm{pH} 2.8$ and 5.0, the fluorescence was negligible at ca. $60 \mathrm{~min}$, in sharp contrast with all other processes where this goal had not been reached.

Regarding the time-course profile of the PARAFAC component, a continuous decrease was observed for both, $\mathrm{C} 1$ and $\mathrm{C} 3$, while a sharp increase was obtained for $\mathrm{C} 2$ in the first stages of the process followed by a fast decrease. Once more, this is ought to the formation of products that cannot be solved by the model and that show similar fingerprints to ENR. C4 appeared at the beginning of the process and then disappeared. Similarly to the system without iron, C5 formation was always negligible, and in fact, was only visible in the model due to the normalization of the EEM during the preprocessing of the dataset (see Experimental Section).

Finally, when comparing Figure 4.33 and Figure 4.34, it can be observed that in the last, the initial score values are slightly lower. This is attributed to the chelation with Fe(III) formed through oxidation of Fe(II) in water, diminishing the fluorescence intensity of these compounds (see the example for ENR in Figure 4.35A-B and Stern-Volmer plots for each FQ in Figure 4.36). Although it is an unexpected behaviour since coordination complexes generally exhibit greater fluorescence quantum yield than the ligand alone, these observations are in line with other works reporting FQ fluorescence quenching in presence of $\mathrm{Fe}(\mathrm{III})$ and some other transition metals or even with 4-quinolone molecules [214-216]. 

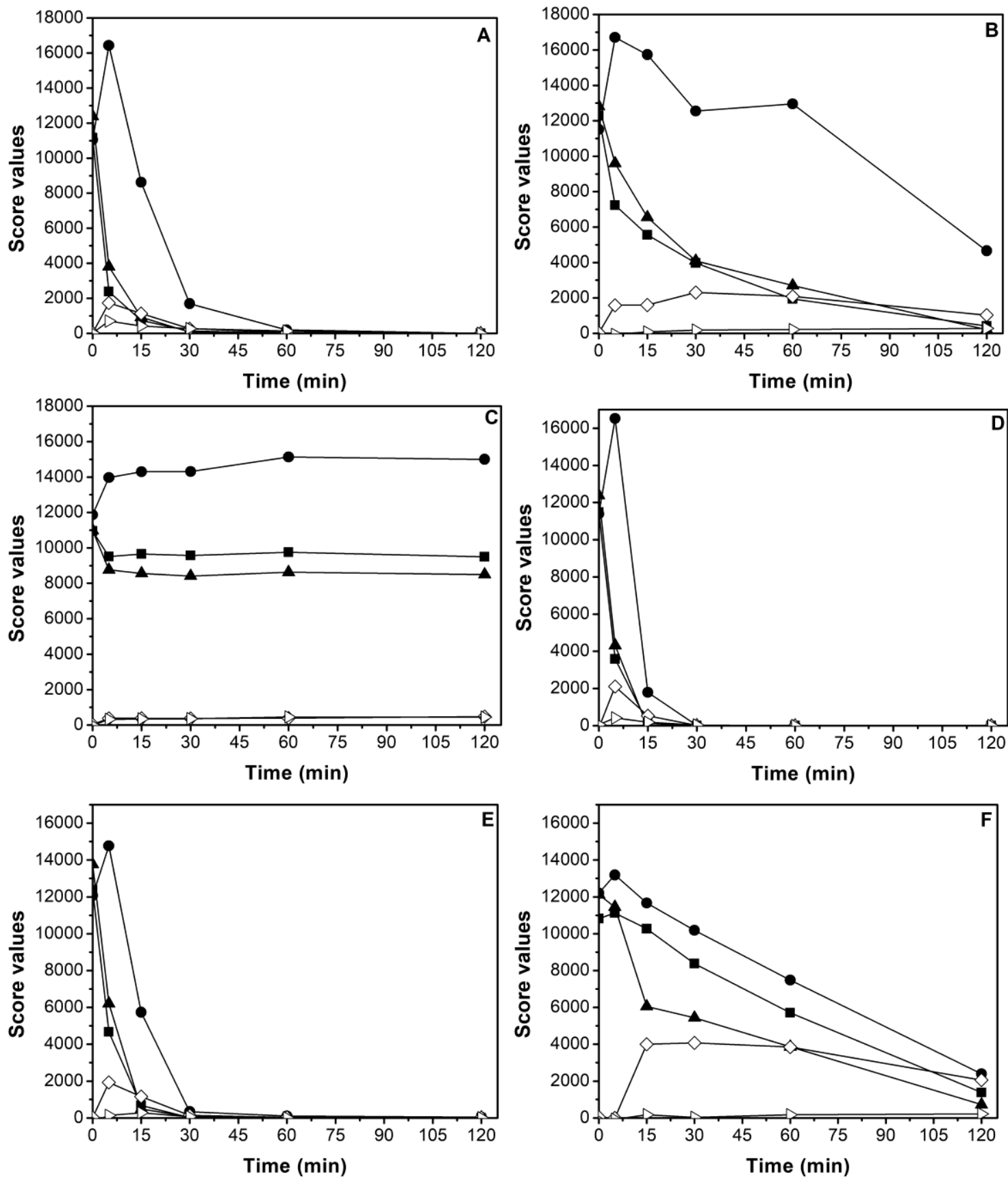

Figure 4.34. OFL, ENR and SAR (8 mg/L each) degradation followed with EEM-PARAFAC (5component model) methodology with Fenton process at pH A) 2.8, B) 5.0 and C) 7.0, photo-Fenton at pH D) 2.8, E) 5.0 and F) 7.0. In all cases $\left[\mathrm{H}_{2} \mathrm{O}_{2}\right]_{0}=125 \mathrm{mg} / \mathrm{L}$, and $[\mathrm{Fe}(\mathrm{II})]_{0}=5 \mathrm{mg} / \mathrm{L}$. PARAFAC components

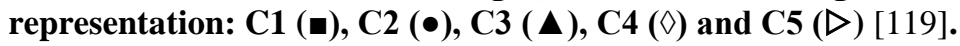

Therefore, in order to prove if Fe presence was an interference for EEM-PARAFAC results, the metal was eliminated previous fluorescence measurements and included in the PARAFAC dataset. This issue was solved by preparing each sample similarly as described in Experimental section, but having $\mathrm{NaOH} 10 \mathrm{mM}$ instead of $\mathrm{H}_{2} \mathrm{SO}_{4}$ to precipitate iron. Afterwards, samples were flown through PTFE filters $0.45 \mu \mathrm{m}$ and acidified again in order to measure them in the same condition as all the predecessors. 
In Figure 4.37A-B, PARAFAC score-values results for dark-Fenton $\mathrm{pH} 7.0$ with iron elimination are shown. Although initial score values did not increase, differences can be observed. For $\mathrm{C} 2$, an increment in score-values was observed, indicating that iron presence produced quenching of by-products emitting in this region and for C3 a slightly faster decay was obtained. For C1, C4 and C5, negligible changes were observed. Nevertheless, the overall trends of the PARAFAC component scores did not change.
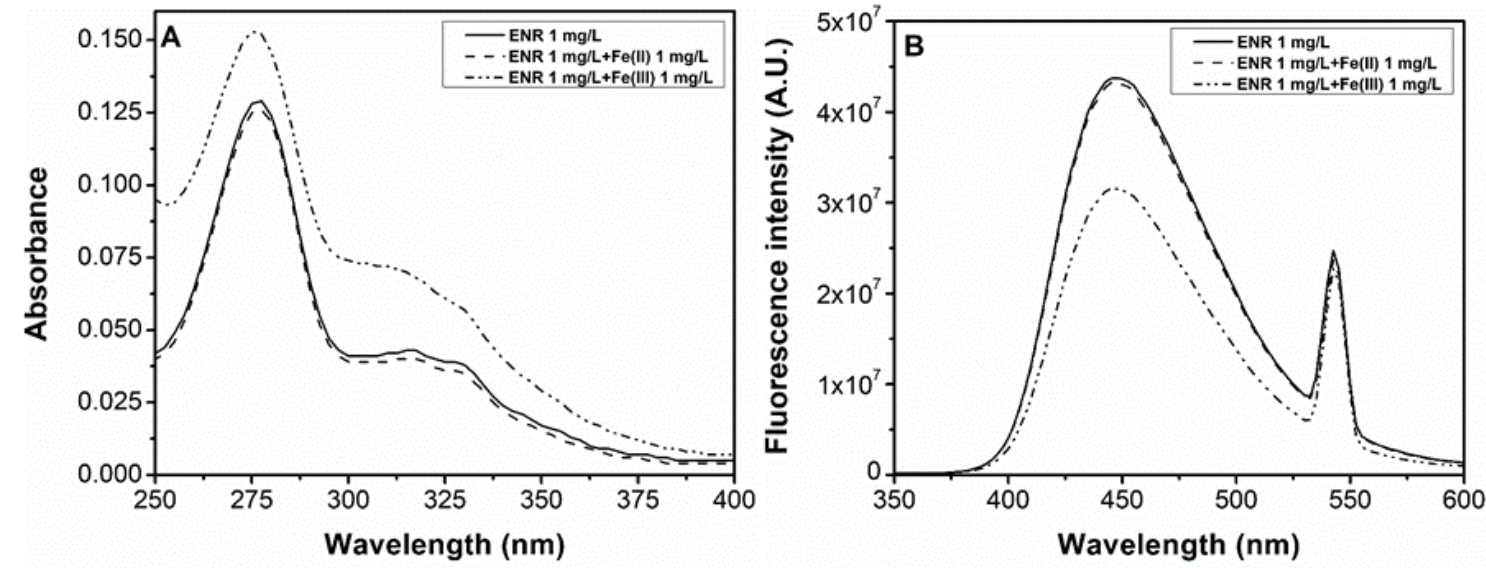

Figure 4.35. Effect of $\mathrm{Fe}(\mathrm{II})$ (added as $\left.\mathrm{FeSO}_{4}\right)$ and $\mathrm{Fe}(\mathrm{III})\left(\right.$ added as $\left.\mathrm{Fe}\left(\mathrm{NO}_{3}\right)_{3}\right)$, both $1 \mathrm{mg} / \mathrm{L}$, in the $\left.\mathrm{A}\right)$ absorbance, and B) fluorescence, spectra of ENR $1 \mathrm{mg} / \mathrm{L}$ containing also $\mathrm{H}_{2} \mathrm{SO}_{4} 5 \mathrm{mM}$ and $\mathrm{CH}_{3} \mathrm{OH} 0.25$ $M$ in all cases [119].

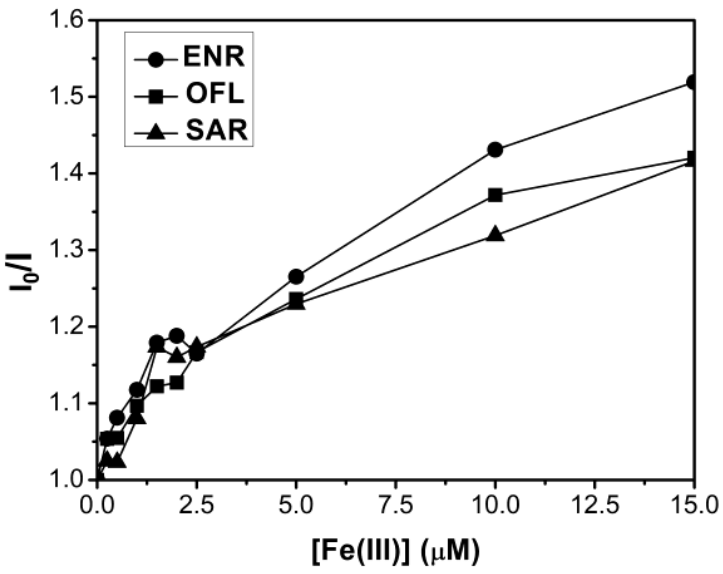

Figure 4.36. Fluorescence quenching produced by Fe(III) (from Fe(NO3) $)_{3}$ ) towards FQs $(1.5 \mu M$ each). The employed excitation and emission wavelengths for each FQ was: ex. $270 \mathrm{~nm}$, em. $450 \mathrm{~nm}$ (ENR); ex. 290, em. $507.5 \mathrm{~nm}$ (OFL); ex. $275 \mathrm{~nm}$, em. $460 \mathrm{~nm}$ (SAR). Quenching produced by $\mathrm{NO}_{3}^{-} 45 \mu \mathrm{M}$ (added as $\mathrm{KNO}_{3}$ ) was negligible in all cases [119]. 

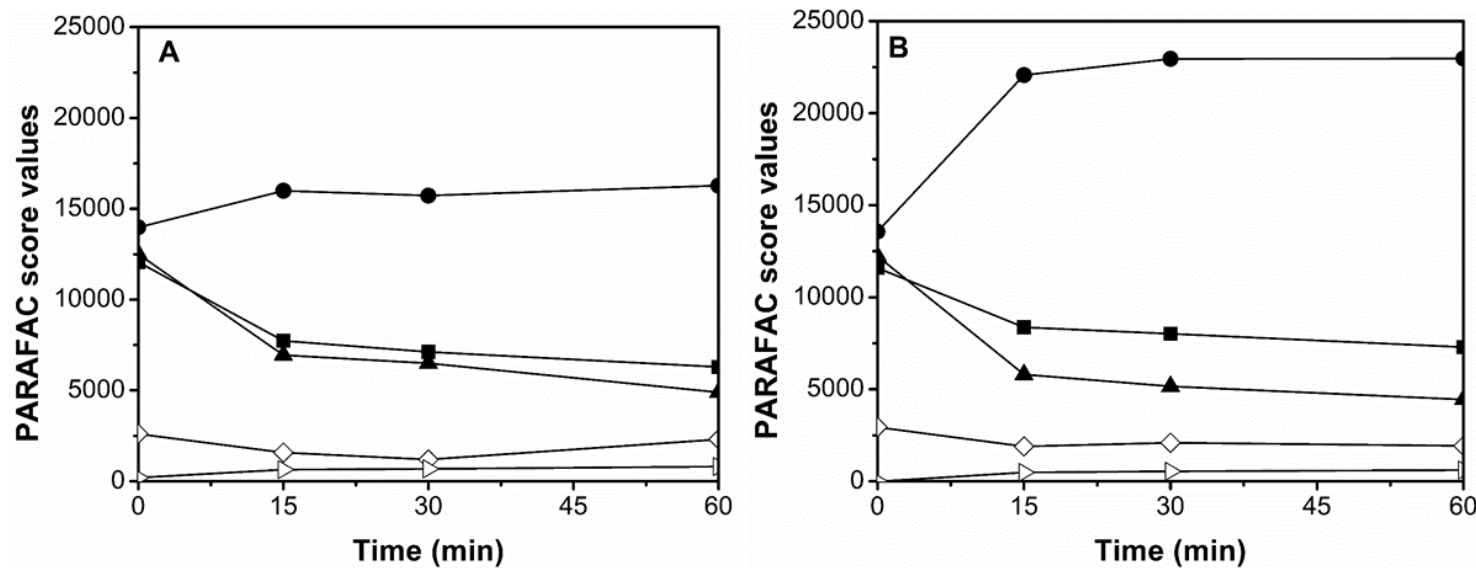

Figure 4.37. Influence of iron towards PARAFAC time-course components score values. Dark-Fenton process at $\mathrm{pH}_{0}=7.0$ : A) normal measurement, B) with iron elimination [119].

\subsubsection{Antibacterial activity}

Antibacterial activity assays were performed for (photo-)Fenton processes and photolysis at $\mathrm{pH} 2.8$, measuring the decay on the diameter of the inhibition halos formed by E. coli strains. Results indicated that only for Fenton and photo-Fenton processes, E. coli started growing again around the wells containing the samples of degradation experiments, thus observing a decrease of the zone of inhibition, whereas it remained constant along the $2 \mathrm{~h}$ of photolysis process.

In Figure 4.38, the zone of inhibition diameter and the summation of the PARAFAC model components decay, both normalized, is shown. Interestingly, antibacterial activity decay presented the same trend than the disappearance of the 5 PARAFAC components. These results are in line with ones reported in the previous work [137], which shows that antibacterial ability might be associated with the FQ core [37,174,217]. 


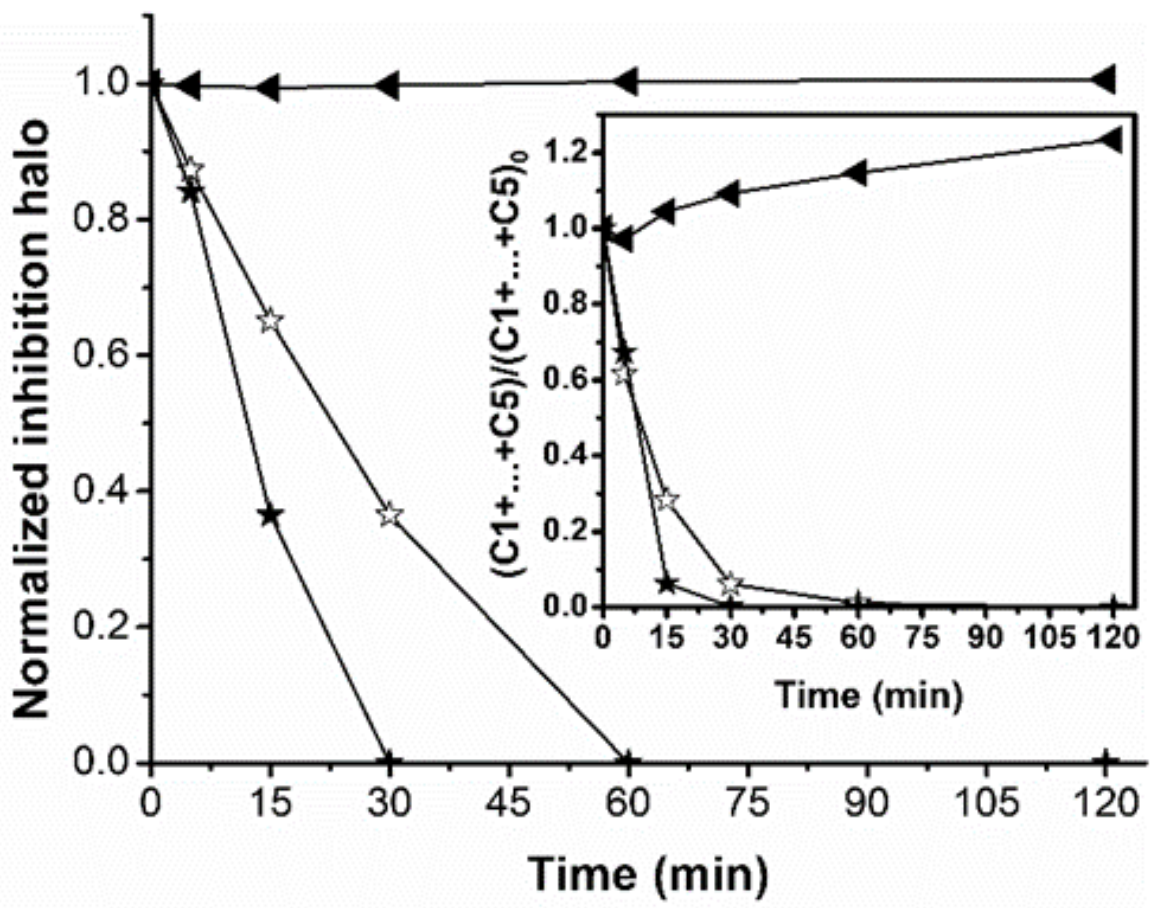

Figure 4.38. Antibacterial activity decay by $E$. coli normalized inhibition halo determinations and, as inserted plot, the summation of component score values $(\mathrm{C} 1+\ldots+\mathrm{C5})$ decay, also normalized, of the FQs mixture $(8 \mathrm{mg} / \mathrm{L}$ each) at pH 2.8 treated with light irradiation ( 4$)$, Fenton ( $\star$ ) and photo-Fenton ( $\star$ ), in this last two, $\left[\mathrm{H}_{2} \mathrm{O}_{2}\right]_{0}=125 \mathrm{mg} / \mathrm{L}$, and $[\mathrm{Fe}(\mathrm{II})]_{0}=5 \mathrm{mg} / \mathrm{L}[119]$.

\subsubsection{Conclusions}

The applicability of EEM- PARAFAC as a complementary tool to monitor the behavior of antibiotics along an AOP has been extended to more complex samples, containing mixtures of several parent compounds. Although it was not able to give detailed data on the chemical substances present, it provides valuable information on the behavior of the FQ core, that can be related with toxicity.

According to the results above reported, three interesting tasks should be addressed in the next future for a better understanding of the process: a) investigate the nature of the interaction between $\mathrm{Fe}$ and the FQs to explain the good performance of photo-Fenton at mild $\mathrm{pH}, \mathrm{b})$ to combine EEM-PARAFAC with smart HPLC-MS analysis to correlate the components obtained in the mathematical model with a compound or group of compounds, c) to explore the real applicability of the methodology here developed with lower pollutant concentrations (e.g $\mu \mathrm{g} / \mathrm{L}$ ), using different aqueous matrices (role of salinity and dissolved organic matter) and scaling it up to higher volumes using real sunlight as irradiation source.

\subsection{Degradation of a mixture of (Fluoro)Quinolones antibiotics with Solar-photo-Fenton with a CPC pilot plant: EEM-PARAFAC use}




\subsubsection{Introduction}

As an extension from previous works $[119,137]$, we have followed with EEMPARAFAC the degradation of a mixture of 5 quinolone-antibiotics: OFL, CIP, ENR, OA and FLU, in different water matrices: MQ, SW and simulated wastewater (SWW). Solar-photoFenton at pilot plant scale was used as water treatment. In all cases, $3 \mu \mathrm{M}$ of each antibiotic was used. Therefore, in this occasion, we applied the already studied EEM-PARAFAC tool but in more realistic conditions.

In addition to this, supplementary experiments have been performed by adding thiabendazole (TBZ) to the aforementioned antibiotics mixture. This allows gaining further insight into the complexing role of quinolones and its implication in mild photo-Fenton, but also to test the ability of EEM-PARAFAC to deconvolute plausible fluorescence interferences.

\subsubsection{Experimental}

\subsubsection{Reagents}

TBZ, FLU, OA, OFL, ENR and CIP high purity (> 99\%), gum Arabic, lignin sulphonic acid sodium, peptone, and humic acid substances were purchased from Sigma-Aldrich. Beef extract from Bovril. $\mathrm{FeSO}_{4} \cdot 7 \mathrm{H}_{2} \mathrm{O}, \mathrm{H}_{2} \mathrm{O}_{2}\left(33 \%\right.$ w/v), $\mathrm{NaHCO}_{3}, \mathrm{NaCl}, \mathrm{NH}_{4} \mathrm{SO}_{4}, \mathrm{NaOH}$, acetic acid (96\%), 1,10-phenanthroline 1-hydrate, $\mathrm{H}_{2} \mathrm{SO}_{4}$ (96\%), and UHPLC grade methanol and acetonitrile, were obtained from AppliChem-Panreac. Ammonium acetate, $\mathrm{K}_{2} \mathrm{HPO}_{4}$, $\mathrm{MgSO}_{4} \cdot 7 \mathrm{H}_{2} \mathrm{O}, \mathrm{CaSO}_{4} \cdot 2 \mathrm{H}_{2} \mathrm{O}$, ascorbic acid and $\mathrm{Fe}_{2}\left(\mathrm{SO}_{4}\right)_{3} \cdot \mathrm{xH}_{2} \mathrm{O}$ from Scharlau. Formic acid $(80 \%)$ was purchased from VWR Chemicals. Ultra-pure water (MQ) was prepared with a Merck Milli-Q system.

FLU, OA, OFL, ENR and CIP $300 \mu \mathrm{M}$ stock solutions were prepared in basic media. TBZ $300 \mu \mathrm{M}$ stock solution was prepared, but acidic media was used in this case. All the solutions were stable at dark conditions and no hydrolysis was observed.

\subsubsection{Degradation experiments}

Degradation of the quinolone, OA, and the 4 fluoroquinolones (from now on, both denoted as (F)Qs) mixture was performed under solar light irradiation in a tubular pilot plant provided with Compound Parabolic Collectors (CPC) (Solardetox Acadus-2001), which was always loaded with $5 \mathrm{~L}\left(V_{T}\right)$ of testing solution containing $3 \mu \mathrm{M}$ of each antibiotic. Therefore, the irradiation time $\left(\mathrm{t}_{30 \mathrm{w}}\right)$ was calculated as Eq. 2.1. The characteristics of the aforementioned reactor are: irradiated surface $\left(\mathrm{S}_{\mathrm{i}}\right)$ of $0.26 \mathrm{~m}^{2}$, irradiated volume $\left(\mathrm{V}_{\mathrm{i}}\right)$ of $1.83 \mathrm{~L}$, and the tilt is 
$30^{\circ}$. On top, a radiometer (Acadus 85) was used to measure the accumulated UVA irradiation $\left(L_{a c}\right)$. Due to the changing solar conditions, $L_{a c}$ was normalized by the solar average intensity, $L$, which is reported to be $30 \mathrm{~W} / \mathrm{m}^{2}$ in Southern Spain [140,141].

Solar-photo-Fenton was studied at initial $\mathrm{pH} 5.0$, adjusted with $\mathrm{H}_{2} \mathrm{SO}_{4}$, in MQ, SW (consisted of $30 \mathrm{~g} / \mathrm{L}$ of $\mathrm{NaCl}$ added to $\mathrm{MQ}$ ), and $\mathrm{SWW}$, which was prepared according to Michael et al., 2013 [218], and its constituents are shown in Table 4.6. For SWW, solar-photoFenton was also conducted without $\mathrm{pH}$ adjustment (ca. 7.5). $100 \mu \mathrm{M}$ of $\mathrm{Fe}^{2+}$ was added (as $\mathrm{FeSO}_{4} .7 \mathrm{H}_{2} \mathrm{O}$ ) at the beginning of the experiment and in the case of hydrogen peroxide consecutive additions of $5 \mathrm{mg} / \mathrm{L}$ of $\mathrm{H}_{2} \mathrm{O}_{2}$ were done every $\mathrm{t}_{30 \mathrm{~W}}=12.5 \mathrm{~min}$. These are typical Fenton reagents' concentrations employed in analogous works [137,191]. Experiments were also repeated in presence of humic substances extracted from olive mill wastes (OMW-HLS); further information about their extraction and use for photo-Fenton enhancement at mild $\mathrm{pH}$ conditions has been previously published [96]. A concentration of $20 \mathrm{mg} / \mathrm{L}$ of OMW-HLS was applied in each case as it has been also proved to be the minimum amount of humic-like substances required when employing ca. $100 \mu \mathrm{M}$ of iron [94].

Table 4.6. SWW constituents.

\begin{tabular}{|cc|}
\hline Reagent & Concentration (mg/L) \\
\hline Gum Arabic & 4.7 \\
\hline Lignin sulphonic acid sodium & 3.3 \\
\hline Peptone & 2.7 \\
\hline Beef extract & 1.8 \\
\hline Humic acid substances & 8.4 \\
\hline $\mathrm{NH}_{4} \mathrm{SO}_{4}$ & 23.6 \\
\hline $\mathrm{NaCl}_{4}$ & 4 \\
\hline $\mathrm{MgSO}_{4}$ & 60 \\
\hline $\mathrm{CaSO}_{4}$ & 60 \\
\hline $\mathrm{NaHCO}_{3}$ & 96 \\
\hline $\mathrm{K}_{2} \mathrm{HPO}_{4}$ & 7 \\
\hline
\end{tabular}

On the other hand, in order to demonstrate with a simple example the ability of (F)Qs to chelate iron, a dark Fenton in MQ at pH 5.0 experiment was performed degrading TBZ $3 \mu \mathrm{M}$ (also later on evaluated as non-calibrated fluorescence interference) in presence and absence of the $5(\mathrm{~F}) \mathrm{Qs}, 3 \mu \mathrm{M}$ each. The concentration of initial $\mathrm{Fe}^{2+}$ was reduced to $15 \mu \mathrm{M}(1: 1$ stoichiometry respect to total (F)Qs), and $5 \mathrm{mg} / \mathrm{L}$ of $\mathrm{H}_{2} \mathrm{O}_{2}$ each $25 \mathrm{~min}$ were added. The experiments were carried out for $2 \mathrm{~h}$ in an open batch reactor containing $250 \mathrm{~mL}$ of testing solution and agitated with magnetic stirring.

\subsubsection{Sample preparation}


Samples were always filtered with $0.45 \mu \mathrm{m}$ PTFE filters (Chromafil Xtra). For HPLC measurements, methanol (in a $2.5 \mathrm{M}$ concentration) was added to the samples to quench the excess of $\mathrm{H}_{2} \mathrm{O}_{2}$. On the other hand, for fluorescence spectroscopy determinations, $1.5 \mathrm{M}$ acetate/acetic buffer $(\mathrm{pH}=4)$ was employed, not only for quenching $\mathrm{H}_{2} \mathrm{O}_{2}$ excess, but also to keep similar measuring conditions between the different water matrices and reaction timeinterval samples. It is widely reported that $(\mathrm{F}) \mathrm{Qs}$ ' fluorescence is strongly $\mathrm{pH}$ dependent, having higher intensities in the $\mathrm{pH}$ range between 3 and 5 [44].

Since (F)Qs fluorescence can be quenched by $\mathrm{Fe}^{3+}$ [119], comparison of EEMPARAFAC with and without iron removal was performed. For those samples without iron, they were previously adjusted to $\mathrm{pH} 11$ with $\mathrm{NaOH} 1 \mathrm{M}$ and filtered with PTFE $0.45 \mu \mathrm{m}$ filters. Then, the acetate/acetic $\mathrm{pH} 4$ buffer was added. However, differences between EEM containing and not the iron were negligible, and this procedure was avoided.

\subsubsection{Chemical analysis}

Pollutants removal ((F)Qs and TBZ when present) were determined by HPLC analysis using a Hitachi Chromaster apparatus with a UV/Vis detector (model 5420) employing a C18 Machery-Nagel column Nucleodur- $\pi 2(250 \mathrm{~mm}$ x $2 \mathrm{~mm}, 5 \mu \mathrm{m})$. The employed mobile phase flow was of $0.25 \mathrm{~mL} / \mathrm{min}$, constituted by formic acid, acetonitrile and methanol, 80:7.5:12.5 (in $\% \mathrm{v} / \mathrm{v}$ ), respectively, for the first $42 \mathrm{~min}$ in isocratic mode, and changing with gradient elution up to 20:50:30 until $70 \mathrm{~min}$. TBZ, CIP, OFL and ENR were measured at $285 \mathrm{~nm}$ whereas FLU and OA, at $250 \mathrm{~nm}$.

EEM were measured in a Horiba PTI Quanta Master 400 spectrofluorometer, equipped with a Xe arc lamp, employing an excitation range of 250 - $400 \mathrm{~nm}$ (recorded with $5 \mathrm{~nm}$ intervals), and emission range of $300-600 \mathrm{~nm}$ (recorded within $2.5 \mathrm{~nm}$ intervals). Absorbance spectrums for inner filter effect corrections were measured with a Hitachi-UH5300 spectrophotometer. The same device was used to measure $\mathrm{H}_{2} \mathrm{O}_{2}$ based on the ammonium metavanadate reagent [144]. Subsequent PARAFAC modelling was performed with Matlab 2020a, with the graphical user interface EEMlab developed in a previous work [122]. The dataset, which also included the calibration in MQ for each individual FQ from 0.5 to $3 \mu \mathrm{M}$, consisted of 127 absorbance spectra and EEM, as well as 14 blanks and water Raman signals at $350 \mathrm{~nm}$, respectively. In all cases, the number of components was assessed according to the chemical consistency of the obtained data and residuals distribution. 
For the dark-Fenton experiment containing the $5(\mathrm{~F}) \mathrm{Qs}$ and the TBZ, the respective timeintervals EEM were included in the aforementioned dataset, and PARAFAC modelling was carried out again. These samples were previously diluted by 1:3 due to the higher fluorescence quantum yield of TBZ. Differently from the (F)Qs, TBZ was not calibrated (its individual EEM was not uploaded into the dataset) in order to be considered as a fluorescence interference.

\subsubsection{Results and discussion}

\subsubsection{Water matrix effect}

Fast degradation was obtained for all 5 pollutants in MQ, reaching $90 \%$ removal in $\mathrm{t}_{30 \mathrm{w}}$ ca. 5 min (Figure 4.39A), with comparable removal rates for the 5 pollutants. Although the solar photo-Fenton process at pH 5.0 is usually slow and incomplete, in the case of (F)Qs, due to their ability to chelate iron, Fenton-type processes are fast even at circumneutral conditions $[137,171,207]$. Moreover, despite their markedly different photolysis stability, quinolones and FQs have comparable kinetic rate constants with $\mathrm{HO}^{\bullet}$ [209]. As $\mathrm{HO}^{\bullet}$ generation during photoFenton reaction is high, similar removal rates are expected, independently from the FQ's chemical structure, as it was also seen in a previous work [119].

When changing the water matrix to SW, degradations were slower than in MQ and differences between the pollutants could be observed: OA and FLU showed a ca. $60 \%$ removal in $\mathrm{t}_{30 \mathrm{~W}} \approx 5 \mathrm{~min}$ whereas for OFL, ENR and CIP was $85 \%$ (Figure $4.39 \mathrm{~B}$ ). This could be attributed to a decrease of the photoactive $\mathrm{Fe}(\mathrm{OH})^{2+}$ species as well as formation of $\mathrm{Fe}^{3+}$ chloride complexes, inhibiting the Fenton-like step (see section 1.6.1.1). In line with these statements, $\mathrm{H}_{2} \mathrm{O}_{2}$ consumption was 4-times higher when performing solar-photo-Fenton in MQ than in SW (80\% of the added amount remained in the medium when the experiment was carried out in MQ, whereas for SW was 20\%). It is important to highlight that these results are opposed to those previously reported for ENR at ca. $70 \mu \mathrm{M}$, Sciscenko et al., 2020 [137], where removal of this pollutant by photo-Fenton at $\mathrm{pH} 5.0$ was faster in SW than in MQ. These differences can be explained based on the different species chelating iron in the previous work and on this one. For the same fixed total iron amount of, approximately, $100 \mu \mathrm{M}$, with higher ENR concentrations $([\mathrm{ENR}] /[\mathrm{Fe}]=0.7)$ most iron is expected to be complexed by ENR, while at lower FQ concentration $([\mathrm{ENR}] /[\mathrm{Fe}]=0.03$, and $[$ total $(\mathrm{F}) \mathrm{Q}] /[\mathrm{Fe}]=0.15)$, chloride-iron complexes are expected to be more predominating.

Towards SWW, the removals at pH 5.0 (Figure 4.39C) showed an intermediate behaviour between MQ and SW, obtaining faster degradations than in SW but slower than in MQ (overall 
$75 \%$ degradation in $5 \mathrm{~min}$ ). In SWW we shall consider, on one hand, the effect of DOM, and on the other, the presence of inorganic salts, in particular phosphates (at $\mathrm{pH} 5.0$ inorganic carbon is low). DOM plays an ambivalent role: on one side, they can act as $\mathrm{HO}^{\bullet}$ quencher and produce inner filter effect [219], hence, decreasing the (F)Qs degradation percentages produced by solar-photo-Fenton and photolysis; on the other side, they can act also as photosensitizer agent (enhancing indirect photolysis by ROS generation), as well as chelating agent of iron, therefore, extending the $\mathrm{pH}$-range where Fenton reaction is efficient. The presence of phosphates might produce a certain grade of Fenton inhibition due to the formation of insoluble iron-phosphates salts [61].

Finally, the experiment with SWW was run at unmodified $\mathrm{pH}(7.5-7.8)$. In this medium, iron inactivation via formation of iron oxides or hydroxides becomes more important, resulting in a clearly worse performance of the process. Moreover, besides phosphates effect, the presence of (bi)carbonates at this $\mathrm{pH}$ shall play a negative role due to $\mathrm{HO}^{\bullet}$ quenching. However, except for OFL with 50\% removal in $60 \mathrm{~min}$, in the same period for FLU, ENR, CIP and OA, ca. 80\% degradation was obtained (Figure 4.39D). This relatively good performance in this harsh water matrix for photo-Fenton should be again attributed to iron complexation (besides the already known (F)Qs and generated quinolone-like by-products) by the humicacid substances. 

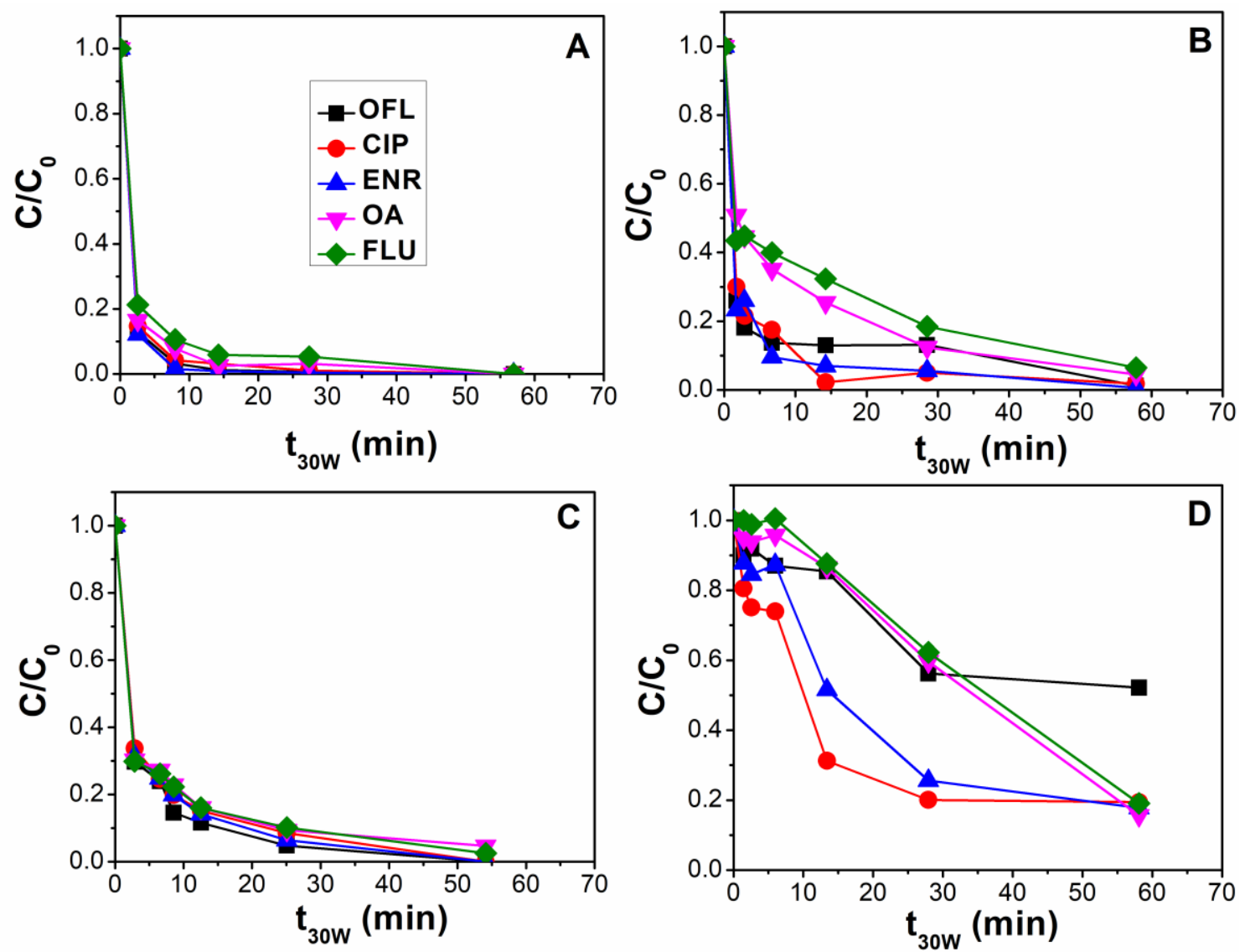

Figure 4.39. (F)Qs, $3 \mu \mathrm{M}$ each, removals with solar photo-Fenton $\left(\left[\mathrm{Fe}^{2+}\right]_{0}=5 \mathrm{mg} / \mathrm{L}\right.$ and additions of $\left[\mathrm{H}_{2} \mathrm{O}_{2}\right]=5 \mathrm{mg} / \mathrm{L}$ every $\mathrm{t}_{30 \mathrm{~W}}=12.5 \mathrm{~min}$ ): A) MQ pH 5.0; B) SW pH 5.0; C) SWW pH 5.0; D) SWW natural pH (ca. 7.5).

\subsubsection{Use of OMW-HLS}

As part of waste revalorization and circular economy policies, the use of OMW-HLS as auxiliary iron chelating agents was studied. In Figure 4.40 the pollutants fate at the different tested water matrices, now in presence of OMW-HLS $20 \mathrm{mg} / \mathrm{L}$, is shown. The overall removal rates were slightly decreased in most cases. The beneficial role of OMW-HLS is attributable to their ability to keep iron active by complexing it; in this case, however, as the (F)Qs already chelate iron (and, eventually, also the DOM in the case of SWW), this role is no longer relevant, and the $\mathrm{HO}^{\bullet}$ quenching and inner filter effects by OMW-HLS become predominating. As a matter of fact, only in the case of SW, where the addition of extra complexing agent may be necessary to remove chloride interferences, some enhancement of the process is observed (compare Figure 4.39B with Figure 4.40B). 

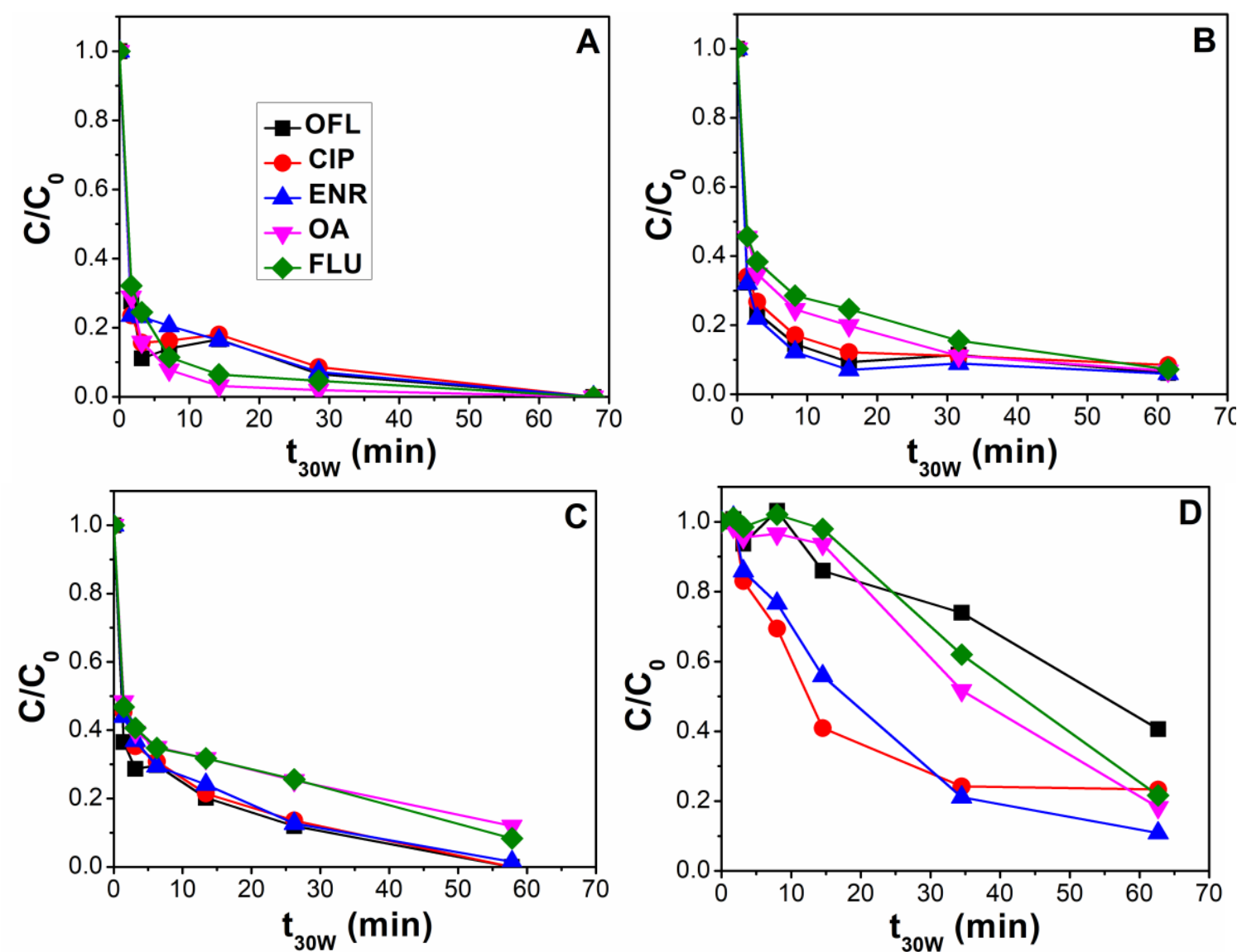

Figure 4.40. (F)Qs, $3 \mu \mathrm{M}$ each, removals with solar photo-Fenton $\left(\left[\mathrm{Fe}^{2+}\right]_{0}=5 \mathrm{mg} / \mathrm{L}\right.$ and additions of $\left[\mathrm{H}_{2} \mathrm{O}_{2}\right]=5 \mathrm{mg} / \mathrm{L}$ every $\mathrm{t}_{30 \mathrm{~W}}=12.5 \mathrm{~min}$ ) with addition of $20 \mathrm{mg} / \mathrm{L}$ of OMW-HLS: A) MQ pH 5.0; B) $\mathrm{SW}$ pH 5.0; C) SWW pH 5.0; D) SWW natural pH (ca. 7.5).

\subsubsection{PARAFAC model}

Figure 4.41 shows the measured EEM for the different pollutants. The fluorescence maxima are as following: ENR and CIP, with analogous EEM, at 273/450 nm excitation and emission axis, respectively, OFL at 295/510, OA 250/375, and FLU 250/360. EEM were also recorded for all the samples taken in the pilot plant experiments (except for those containing OMW-HLS). Examples of those plots are also given in Figure 4.41. 


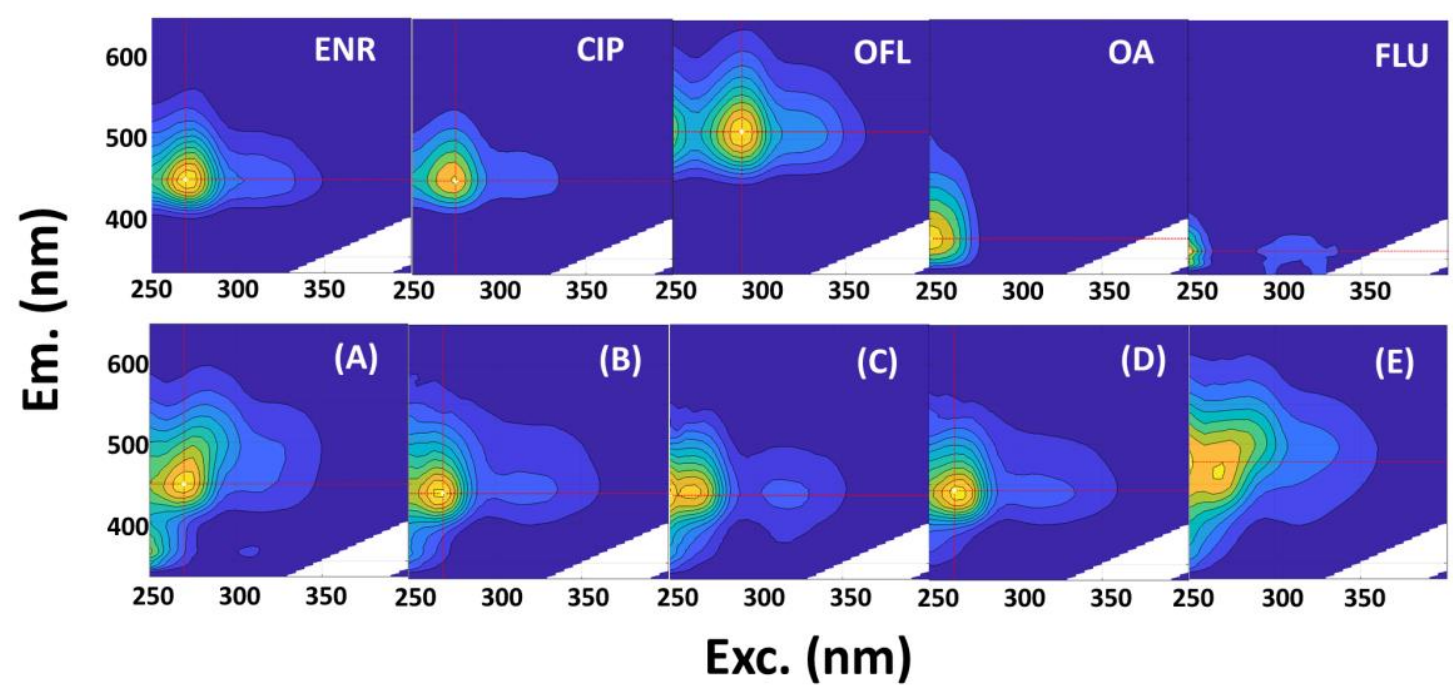

Figure 4.41. Measured EEM for the different (F)Qs (first line) and from their mixture after different reaction time intervals and water matrices: $A) t_{30 \mathrm{~W}}=0 \mathrm{~min}$ in $\left.\left.M Q, B\right) M Q t_{30 \mathrm{~W}}=\mathbf{1 4 . 2} \mathrm{min}, \mathrm{C}\right) \mathrm{SW}$ t30w $=$ $58 \mathrm{~min}, \mathrm{D}) \mathrm{SWW}$ t30W $=54 \mathrm{~min}$, and $\mathrm{E}$ ) $\mathrm{SWW}$ natural pH t30W $=58 \mathrm{~min}$.

When performing the EEM-PARAFAC model, we found that 6 factors could describe the whole dataset, even though it was not validated by conventional algorithms such as splithalf analysis nor core consistency diagnostic [117].

As shown in Figure 4.42, components C2, C3 and C4 fingerprints perfectly fits with the ones of OFL, OA and FLU, respectively. On the other hand, component $\mathrm{C} 1$ fits with the one of ENR and CIP, the model not being able to deconvolute EEM between these two, due to their analogous EEM. In this sense, the aforementioned components will also consider scores coming from generated by-products with similar EEM fingerprints to the parent pollutants. For instance, in addition to ENR and CIP, also some oxidation by-products will also contribute to component C1 scores, which we will call ENR/CIP-like; in fact, as previously mentioned, CIP is one major ENR's photoproduct [118]. The same thought is applied for the other three components: C2 scores are the sum of OFL but also OFL-like compounds, and so on with C3 and $\mathrm{C} 4$ for OA+OA-like and FLU+FLU-like ones, respectively.

On the other hand, components $\mathrm{X} 1$ and $\mathrm{X} 2$ belong to non-calibrated substances. Evidently, X1 with fluorescence maximum ca. 270/435 nm (slight blue-shift of ENR/CIP-like component), should be assigned to transformation products originated from ENR and CIP. In fact, X1 component was also detected in a previous work while degrading ENR with photoFenton employing simulated sunlight [137]. On the other hand, transformation products emitting in the X2 region exhibit its excitation maximum at wavelengths $<250 \mathrm{~nm}$, and emission at ca. $460 \mathrm{~nm}$, what might represent deeper structural changes, as it was also 
hypothesized in previous studies $[119,137]$. Moreover, X2 also includes the DOM from SWW matrix, as HLS emits within X2 region [220].

The obtained model is used to correlate the score values of the individual EEM for each (F)Q with their fluorescence intensity. This calibration curve for each individual antibiotic is shown in Table 4.7, being FLU the one with the lowest sensitivity compared with the other 4 compounds in line with its minor fluorescence intensity for equal concentrations.
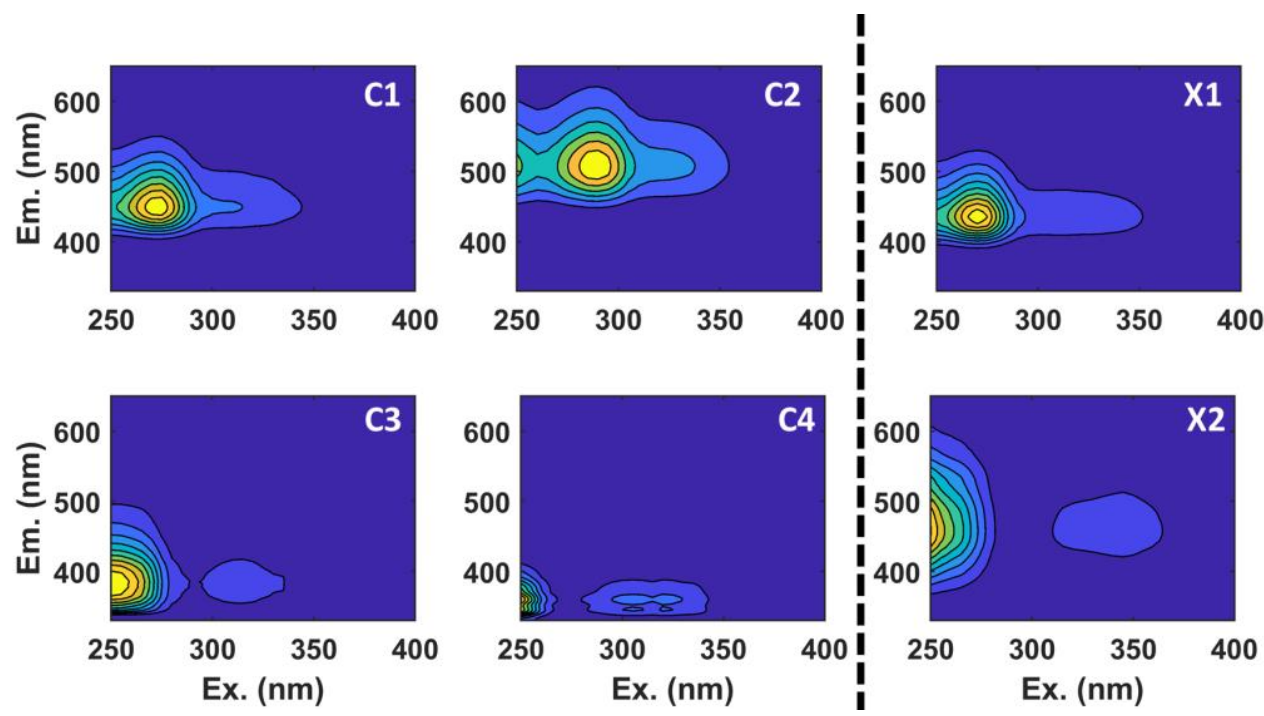

Figure 4.42. EEM-PARAFAC 6-component model fingerprints.

Table 4.7. Calibration curves linear regressions (only three standards each: $0.5,1.5$ and $3 \mu \mathrm{M}$ in MQ) employing the obtained 6-component model fitting the individual EEM of each compound.

\begin{tabular}{|ccc|}
\hline Compound & Slope $\left(\boldsymbol{\mu \mathbf { M } ^ { - 1 } )}\right.$ & Detection limit $(\boldsymbol{\mu M})$ \\
\hline OFL & $33.3 \pm 0.6$ & $0.10 \pm 0.03$ \\
\hline CIP & $21.4 \pm 0.6$ & $0.02 \pm 0.05$ \\
\hline ENR & $37.6 \pm 0.8$ & $0.23 \pm 0.03$ \\
\hline OA & $20.5 \pm 0.4$ & $0.10 \pm 0.05$ \\
\hline FLU & $8.9 \pm 0.2$ & $0.2 \pm 0.4$ \\
\hline
\end{tabular}

4.5.3.4.EEM-PARAFAC simultaneous monitoring - by-product formation

When analysing the analogous samples from the different degradation time intervals by EEM-PARAFAC, parent pollutants, fluorescent by-products and DOM were measured all at once (Figure 4.43).

(F)Qs components' normalized scores in MQ followed an analogous trend than the observed by HPLC. As expected, they exhibited slightly slower decay than the chromatographic areas due to the contribution of by-products to the overall fluorescence, as discussed above. For instance, C4 scores (FLU and FLU-like by-products) had a decay of 78\% 
at $\mathrm{t}_{30 \mathrm{~W}}=8 \mathrm{~min}$ in MQ (Figure 4.43A), whereas FLU removal was $90 \%$ in the same period according to HPLC (Figure 4.39A).

In SW most of the fluorescent generated by-products emit within the OA region, thus $\mathrm{OA}+\mathrm{OA}-\mathrm{like}$ scores exhibiting an utterly slower decay rate compared to the one of the pollutant alone (Figure 4.43B vs. Figure 4.39B, respectively). This strong blue-shifts might be attributed to plausible chlorination of FQs, thus emitting at shorter wavelengths.

For SWW at pH 5.0, PARAFAC components' scores (Figure 4.43C) showed the same trend than the observed for the individual pollutants. However, at its natural $\mathrm{pH}$, the transformation by-products clearly emit within the region of ENR and CIP region, since while observing ENR and CIP removals of 80\%, respectively, at $\mathrm{t}_{30 \mathrm{~W}}=30 \mathrm{~min}$ (see Figure 4.39D), C1 score values only exhibited a 30\% decay in the same period (Figure 4.43D).
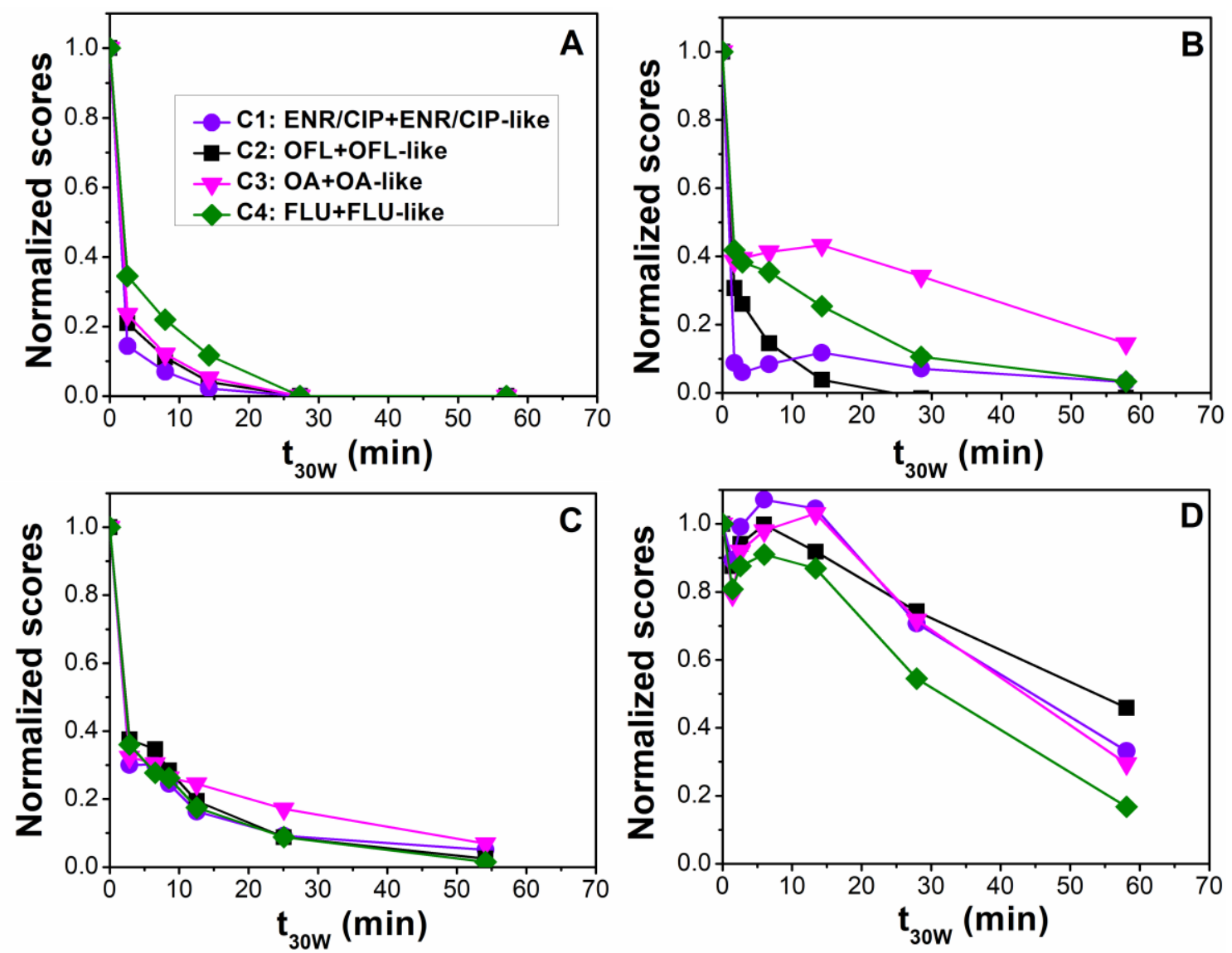

Figure 4.43. (F)Qs, $3 \mu \mathrm{M}$ each, removals with solar photo-Fenton $\left(\left[\mathrm{Fe}^{2+}\right]_{0}=5 \mathrm{mg} / \mathrm{L}\right.$ and additions of $\left[\mathrm{H}_{2} \mathrm{O}_{2}\right]=5 \mathrm{mg} / \mathrm{L}$ every $\mathrm{t}_{30 \mathrm{w}}=\mathbf{1 2 . 5} \mathrm{min}$ ) monitored with EEM-PARAFAC: A) MQ pH 5.0; B) SW pH 5.0; C) SWW pH 5.0; D) SWW natural pH (ca. 7.5).

Finally, components X1 and X2 were also plotted. X1 appeared in every water matrix, with clear kinetics of reaction intermediate: an initial increase, followed by a decrease (Figure 4.44A). In agreement with slower degradation rates, $\mathrm{X} 1$ formation/consumption was slower in 
SWW at natural pH than at 5.0. In SW, the formation of these by-products seems to be relevant, as it exhibited the highest scores from all the tested water matrices (even though we could not strictly compare fluorescent behaviors within different water matrices). As mentioned in section 4.5.3.1, this could be attributable to the lower performance of Fenton-like step due to $\mathrm{Fe}^{3+}$-chloride coordination complexes [86], thus accumulating a higher quantity of X1 byproducts.

On the other hand, when analysing X2 scores (Figure 4.44B), it can be observed that in SWW has non-zero values at $\mathrm{t}_{30 \mathrm{~W}}=0 \mathrm{~min}$ due to DOM contribution. In these cases, $\mathrm{X} 2$ scores exhibit a first fast decay followed by a marked increase. For instance, at $\mathrm{SWW}$ at natural $\mathrm{pH}$, $\mathrm{X} 2$ scores passed from 7 to 0 in less than $5 \mathrm{~min}$, and afterwards increased until 20 in barely 10 min, keeping constant until the end of the assay. Therefore, the first X2 scores decay shall be related to DOM oxidation, whereas the subsequent increment due to oxidated pollutants formation. Moreover, differently from component X1, X2 scores increment and decay is perfectly correlated with the observed (F)Qs degradation rates. Their final scores are the highest in SWW (natural pH ), followed by SW, SWW and MQ (all at pH 5.0, respectively).
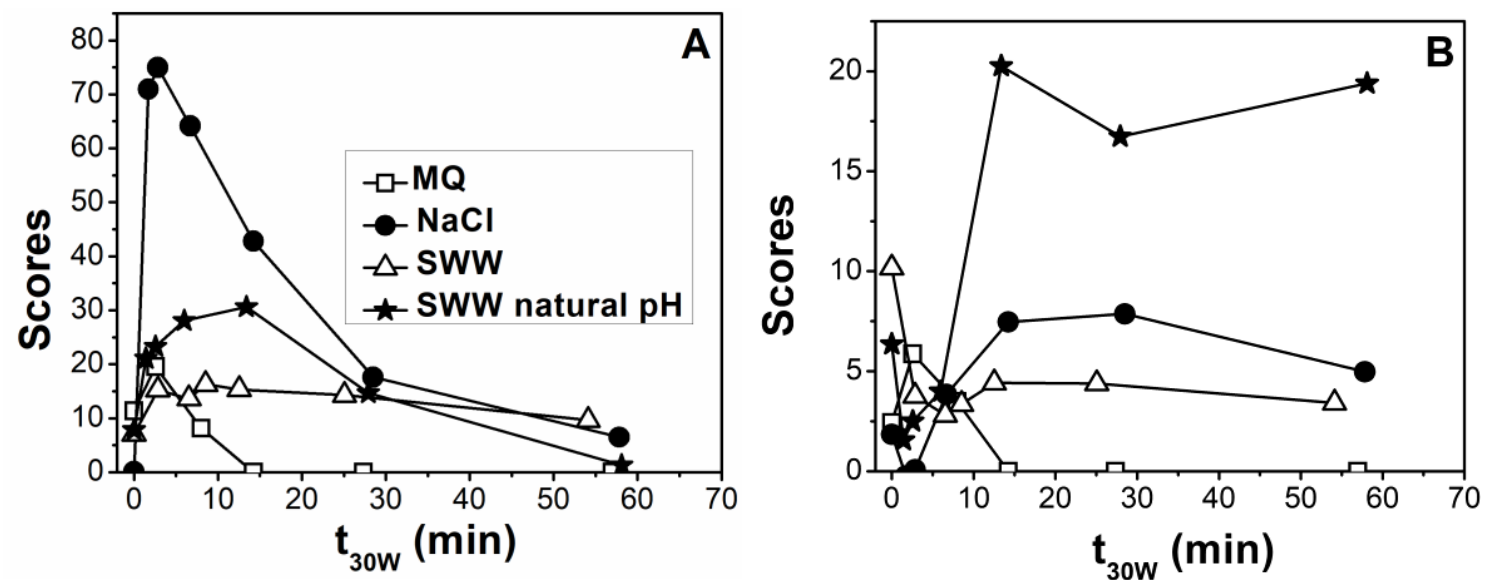

Figure 4.44. EEM-PARAFAC scores from non-calibrated found components in the different studied water matrices, A) X1 and B) X2.

\subsubsection{TBZ addition}

In order to demonstrate with a simple example the ability of (F)Qs to chelate iron, a dark Fenton in MQ at pH 5.0 experiment was performed to treat TBZ $3 \mu \mathrm{M}$ in presence and absence of the 5 (F)Qs, $3 \mu \mathrm{M}$ each. The concentration of initial $\mathrm{Fe}^{2+}$ was $15 \mu \mathrm{M}$ and $5 \mathrm{mg} / \mathrm{L}$ of $\mathrm{H}_{2} \mathrm{O}_{2}$ every 25 min were added.

TBZ removal was $>90 \%$ in 120 min in presence of the $(\mathrm{F}) \mathrm{Qs}$, but $50 \%$ in the absence (Figure 4.45). This issue is not usually considered when performing fundamental studies of 
CECs mixtures also containing FQs antibiotics, plausibly reaching misinterpretations of faster pollutant degradations with Fenton reactions.

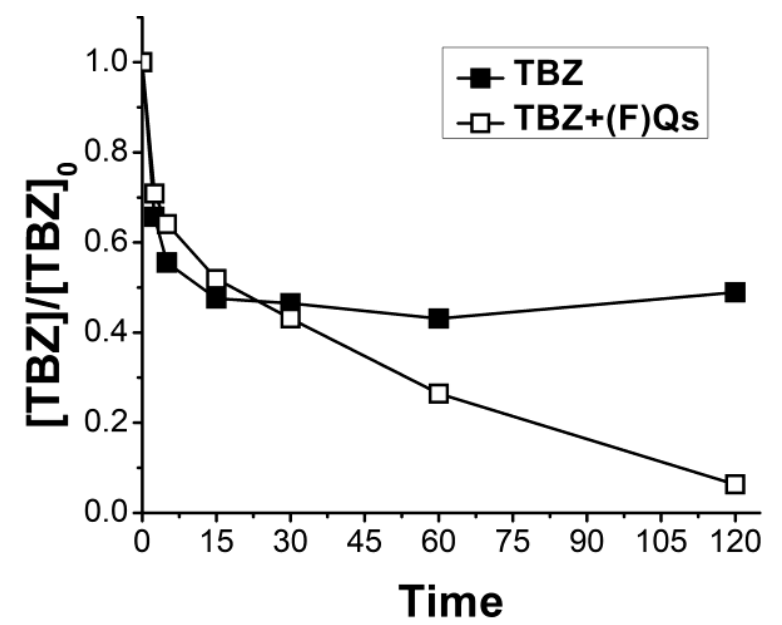

Figure 4.45. TBZ $3 \mu \mathrm{M}$ Fenton degradation in $\mathrm{MQ}$ at $\mathrm{pH}$ 5.0, employing $15 \mu \mathrm{M}$ of $\mathrm{Fe}^{2+}$ and $5 \mathrm{mg} / \mathrm{L}$ each 25 min dosage of $\mathrm{H}_{2} \mathrm{O}_{2}$, in absence and presence of the (F)Qs mixture, OFL, CIP, ENR, OA and FLU, each in concentration $3 \mu \mathrm{M}$.

Taking advantage of the Fenton with TBZ and (F)Qs, the intermediate samples were also analysed by fluorescence spectroscopy, and its EEM introduced in the previously used PARAFAC dataset to perform a new modelling, but now with another fluorescence interference with even higher fluorescence quantum yield than the parent compounds (these samples had to be diluted by a factor of 3). Therefore, differently from (F)Qs, TBZ was not calibrated (TBZ individual EEM, and at different concentrations, was not introduced into the dataset).

In Figure 4.46A, the model of 7 components, which now includes TBZ, is shown; accordingly, in Figure 4.46B the kinetics during the aforementioned dark-Fenton reaction is represented. Therefore, EEM-PARAFAC allows the simultaneous determination of the parent pollutant, generated by-products, and also other non-calibrated compounds (known as second order advantage), even if the interference presents comparable, or higher, fluorescence intensity than the analytes. 
A
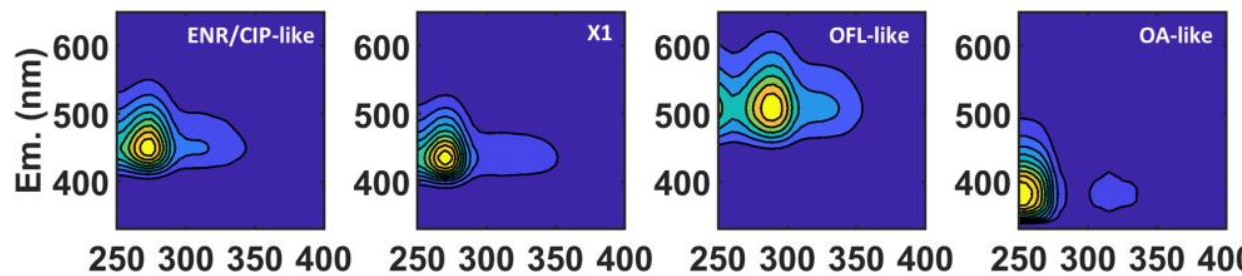

250300350400

250300350400

250300350400

250300350400
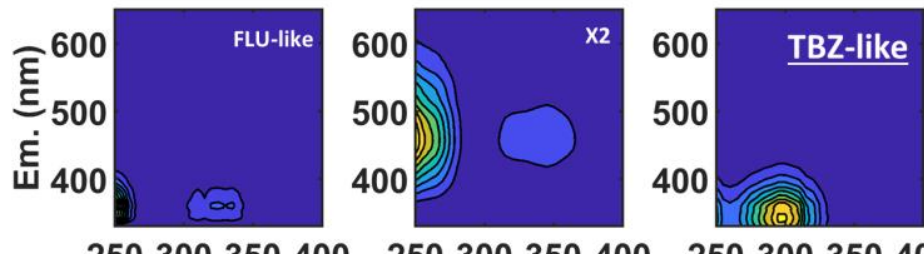

250300350400

250300350400250300350400

Ex. (nm)

Ex. $(\mathrm{nm})$

Ex. (nm)

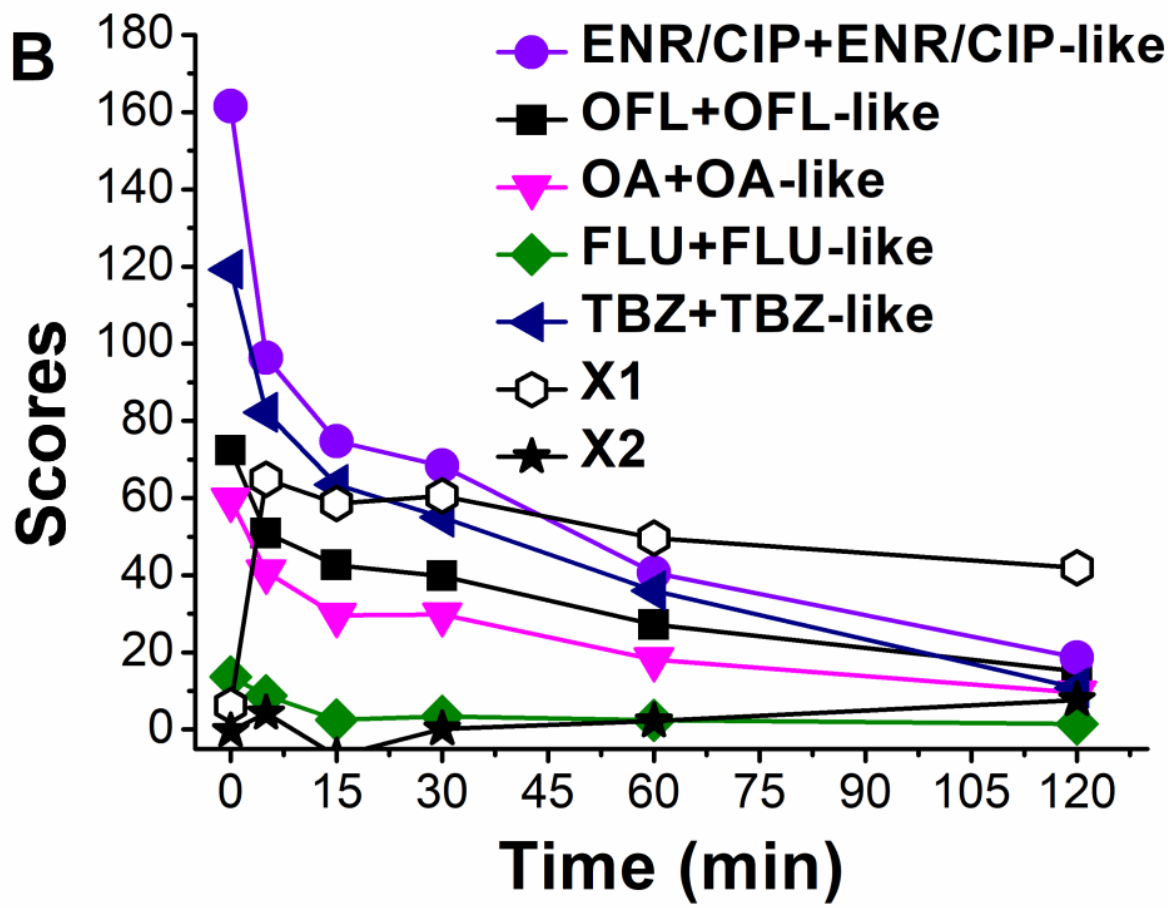

Figure 4.46. EEM-PARAFAC model containing Fenton degradation of TBZ $3 \mu \mathrm{M}$ and the tested (F)Qs:

A) 7-component model; B) scores behaviour for each component.

\subsubsection{Conclusions}

EEM-PARAFAC was able to track the overall changes during (solar-photo-)Fenton treatments of the parent pollutants, oxidation by-products, DOM and added interferences (TBZ). Sample preparation only required the use of $\mathrm{pH} 4$ buffer solution in order to keep constant $\mathrm{pH}$ between the different cases. As shown in previous works, results are complementary to the HPLC ones (pollutant individual degradations), giving a fast vision of the situation happening inside the reactor in an easy and low-cost way.

\subsection{Dissolved organic matter monitoring among the Turin drinking water plants employing EEM-PARAFAC}


This section has been carried out in collaboration with the AQUAlity beneficiary, Società Metropolitana Acque Torino (SMAT, Turin, Italy). The information here shown was sent to Water journal the $9^{\text {th }}$ June 2021, and the authors are: Sciscenko, Iván; Arques, Antonio; Escudero-Oñate, Carlos; Oller, Isabel; Papagiannaki, Dimitra; Binetti, Rita.

\subsubsection{Introduction}

DOM has been characterized and monitored along with the treatment line of the DWTPs responsible for supplying drinking water to about $20 \%$ of the Turin inhabitants (Piedmont, Italy). This tracking has been performed employing EEM-PARAFAC and comparing its outcomes with data from more accepted quality controls such as NPOC and UVa. The effects of the different treatment steps on the behaviour of the obtained scores for each PARAFACmodelled component were evaluated with the aim to improve the efficiency of the plants and adapt its application to tackle the recurring issue of seasonal algal blooms. More specifically, the treatment step facing the largest problem is the lagooning pre-treatment, which has been included in the studied DWTP scheme in order to improve the characteristics of treated water and reduce the amounts of chemical reagents needed along with the different processes.

\subsubsection{Experimental}

\subsubsection{Description of the working environment: the DWTP of Turin}

Società Metropolitana Acque Torino (SMAT) is the company in charge of water cycle management in the Metropolitan Area of Turin. SMAT operates drinking, and wastewater, treatment plants, as well as the distribution networks in the area, supervising 293 municipalities and supplying a population of about 2.3 million inhabitants. On behalf of the studied DWTP reported in this work (schematized in Figure 4.47A), the description of the treatment steps is described below.

The studied DWTP is treating a mix of water from the river Po $(\mathrm{C})$ and a lagoon located about $10 \mathrm{~km}$ upstream (A and B, for inlet and outlet, respectively). Water from sites B and C is mixed and passed through a wire mesh filter, which removes most of the coarse contaminants and sediments (site D) before flowing into the treatment plant. Then, the water passes through a static horizontal flow pre-settling basin equipped with a rotary dredge for the mechanical removal of sludge, where additives (flocculants and coagulants) can also be used to promote the sedimentation process. At the outlet of the pre-settling basin (site E) the treatment plant is divided into two different lines, Po1/Po2 (with an output of $1100 \mathrm{~L} \mathrm{~s}^{-1}$ ) and Po3 (with an output of $\left.1500 \mathrm{~L} \mathrm{~s}^{-1}\right)$. 
For the two identical treatment lines, $\mathrm{Po} 1 / \mathrm{Po} 2$, a pre-chlorination step takes place using chlorine dioxide $\left(\mathrm{ClO}_{2}\right)$ and sodium hypochlorite $(\mathrm{NaClO})$. Subsequently, the water is headed to the clarification step (L), consisting of an "Accelerator" type sludge recirculation tank. Finally, the treated water is filtered on granular activated carbon (GAC in the scheme) and accumulated in a tank where the final disinfection step with $\mathrm{ClO}_{2}$ occurs (site $\mathrm{M}$ ).

Regarding the other parallel line, Po3, after the first sedimentation step, the water undergoes an ozonation process (site F). Right after, the water is transferred to three parallel CYCLOFLOC clarifiers (where precipitation of the sludge formed takes place promoted by the addition of aluminium polychloride and microsand). From two of the CYCLOFLOC basins (site $\mathrm{H}$ ), the water is headed to 16 biological treatment units (denoted as BAC in the scheme). In the other basin, a further oxidation treatment with $\mathrm{NaClO}$ takes place to eliminate $\mathrm{NH}_{3}$ and nitrogenated compounds (site G) and afterwards the water is passed through 12 parallel granular activated carbon filtration lines units. The uppermost and lowermost filters consist of $0.80 \mathrm{~m}$ thick filtering surface of granular activated carbon, that retains any particles left in the water after the settling process. After the filtration, the water is transferred to a tank where a final disinfection treatment with $\mathrm{ClO}_{2}$ takes place in order to avoid the regrowth of bacterial colonies along with the distribution system during the delivery of the water to the final users (site I). 

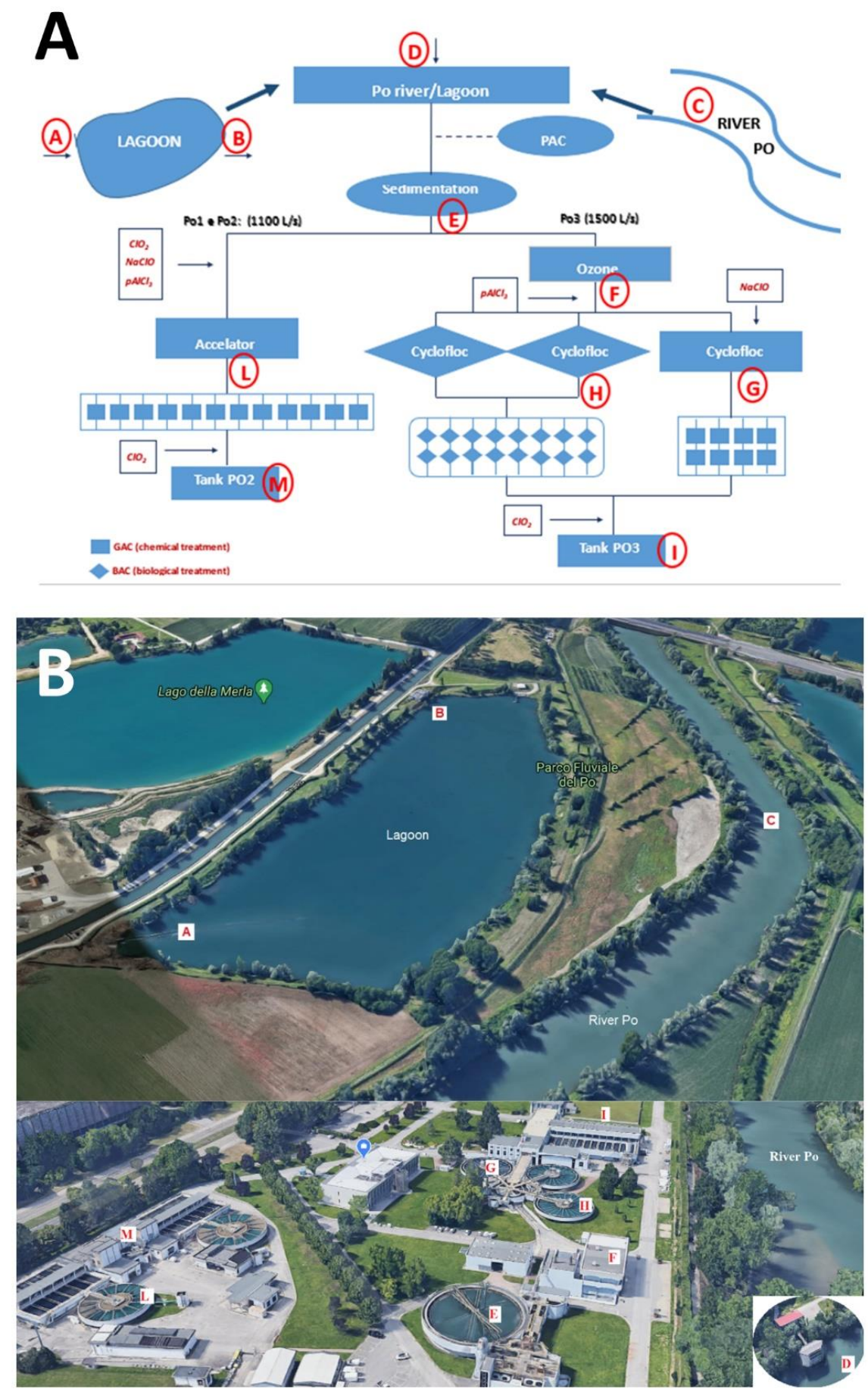

Figure 4.47. Sampling sites from SMAT DWTP, A) scheme, B) air picture.

\subsubsection{Sampling}

Water samples were collected through two different sampling campaigns, carried out in April and August 2019. Each campaign lasted one week and samples were taken from each sampling point at the same time each day. Samples from sites A to M were collected in dark glass vials $(24 \mathrm{~mL})$ with Teflon septum and stored at $2-10^{\circ} \mathrm{C}$ for up to 7 days before their analysis. A constant $\mathrm{pH}=8.0 \pm 0.3$ was observed for all samples. 


\subsubsection{Analysis}

NPOC and dissolved organic carbon were determined using a Shimadzu TOC- $\mathrm{V}_{\mathrm{CPH}}$ Total Organic Carbon Analyzer equipped with a Shimadzu ASI-V autosampler. Prior to the analyses, samples were acidified with $\mathrm{HCl} 2 \mathrm{M}$ and so all the inorganic carbon was removed after purging with air. For dissolved organic carbon determinations, samples were previously filtered with $0.45 \mu \mathrm{m}$ Whatman cellulose filters. However, since these values presented no significant differences with NPOC ones, only the last ones are here reported. UVa was measured using a Hach Lange DR6000 spectrophotometer. EEM from both, samples and blanks, were recorded employing a Horiba PTI Quanta Master 400 spectrofluorometer, excitation range: 250-400 nm, and emission range: 300-600 $\mathrm{nm}$ (both recorded within $5 \mathrm{~nm}$ intervals). Intensity standardization was carried out by using water Raman scatter peak at $350 \mathrm{~nm}$ excitation wavelength [146]. Water samples were previously filtered by Chromafil Xtra PTFE $0.45 \mu \mathrm{m}$ filters.

\subsubsection{EEM-PARAFAC}

The chemometric analysis was performed employing MATLAB2018b, with a free graphical user interface based on the drEEM toolbox, EEMlab [122]. The dataset consisted of 88 EEM, 6 blanks and 6 Raman scans. Model appropriateness was chosen according to the above mentioned statements.

\subsubsection{Results and discussion}

\subsubsection{PARAFAC model}

Three models were explored in this EEM-PARAFAC analysis, decomposing the EEM in 2, 3 and 4 components, respectively. According to CORCONDIA results (Table 4.8), the model which best fitted the data was the one with 3 components, since an abrupt decrease in the core consistency was observed between the 3 and 4-component model. When performing the splithalf analysis, this model was validated with a 0.95 Tucker's correlation coefficient. Residuals were also distributed randomly (Table 4.9).

Table 4.8. CORCONDIA obtained results for each tested PARAFAC model.

\begin{tabular}{|c|c|}
\hline Number of components & CORCONDIA (\%) \\
\hline 2 & 92.5 \\
\hline 3 & 98.0 \\
\hline 4 & 11.7 \\
\hline
\end{tabular}


Table 4.9. Measured, modelled and residuals from some example sampling points obtained for the 3component PARAFAC model.

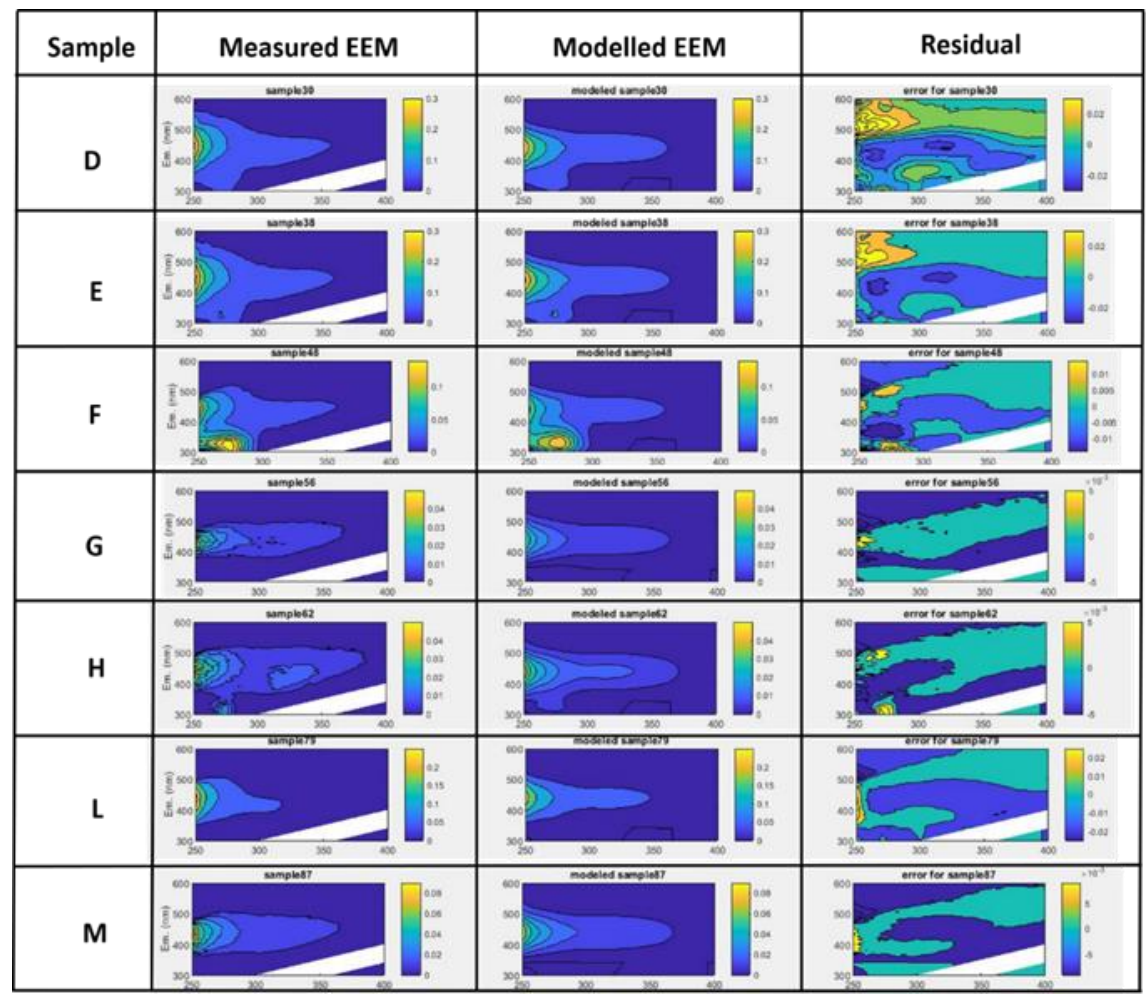

All three modelled fingerprints can be found in Figure 4.48. According to their excitation and emission maximums, the PARAFAC components can be characterized as following: deconvoluted component number 1 (C1), with maximum $<250 \mathrm{~nm}$ excitation axis and ca. 440 $\mathrm{nm}$ emission axis, that could be associated with either terrestrial-humic or humic acid-like substances (HA-L). C2 with 270/330 nm excitation/emission axis could be assigned to tryptophan-like substances (Try-L). Finally C3, with its maximal at <250/300 nm, most likely can be associated with tyrosine-like substances (Tyr-L) [124,220]. In this sense, C2 could be considered the most relevant component regarding quality assurance monitoring, as it is reported that Try-L are potential indicators of Escherichia coli presence, and algal organic matter could be also associated with C1 [221,222]. 

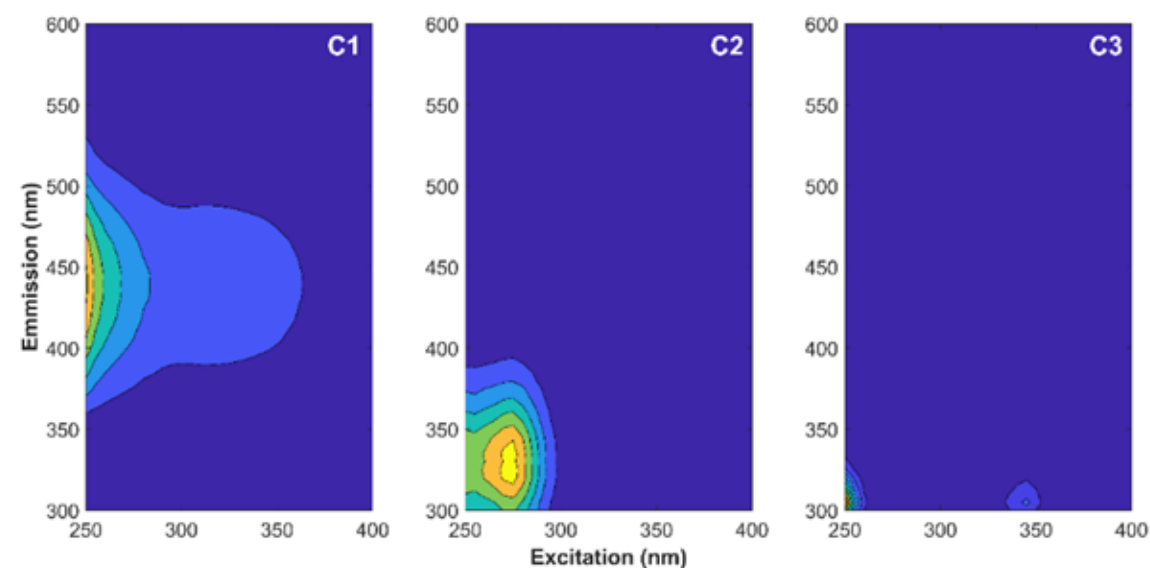

Figure 4.48. Fingerprints from the 3-component PARAFAC model. Each component, $\mathrm{C} 1, \mathrm{C} 2$ and $\mathrm{C} 3$, can be correlated with HA-L, Try-L and Tyr-L substances, respectively.

\subsubsection{DOM monitoring}

As shown in Figure 4.49, when analyzing the score values from each modelled component, the HA-L and Try-L were found in comparable amounts along with the whole dataset, whereas Tyr-L score values were negligible in all cases, only detected at the outlet of both treatment lines (sites I and M). It is noteworthy to highlight that score values cannot be related straight to the abundance of each chromophore, as the fluorescence emission is not only dependent on the concentration but also on the quantum yield, which is characteristic of each chromophore.

For its better comprehension, in this section, the evolution of PARAFAC components score values (fluorescence intensity) within the DWTP (Figure 4.47A-B) were analysed independently in: i) inlet to the DWTP up to sedimentation step (sites A, B, C, D and E), ii) treatment line Po3 (sites F, G, H and I), and iii) treatment lines Po1/Po2 (sites L and M). 


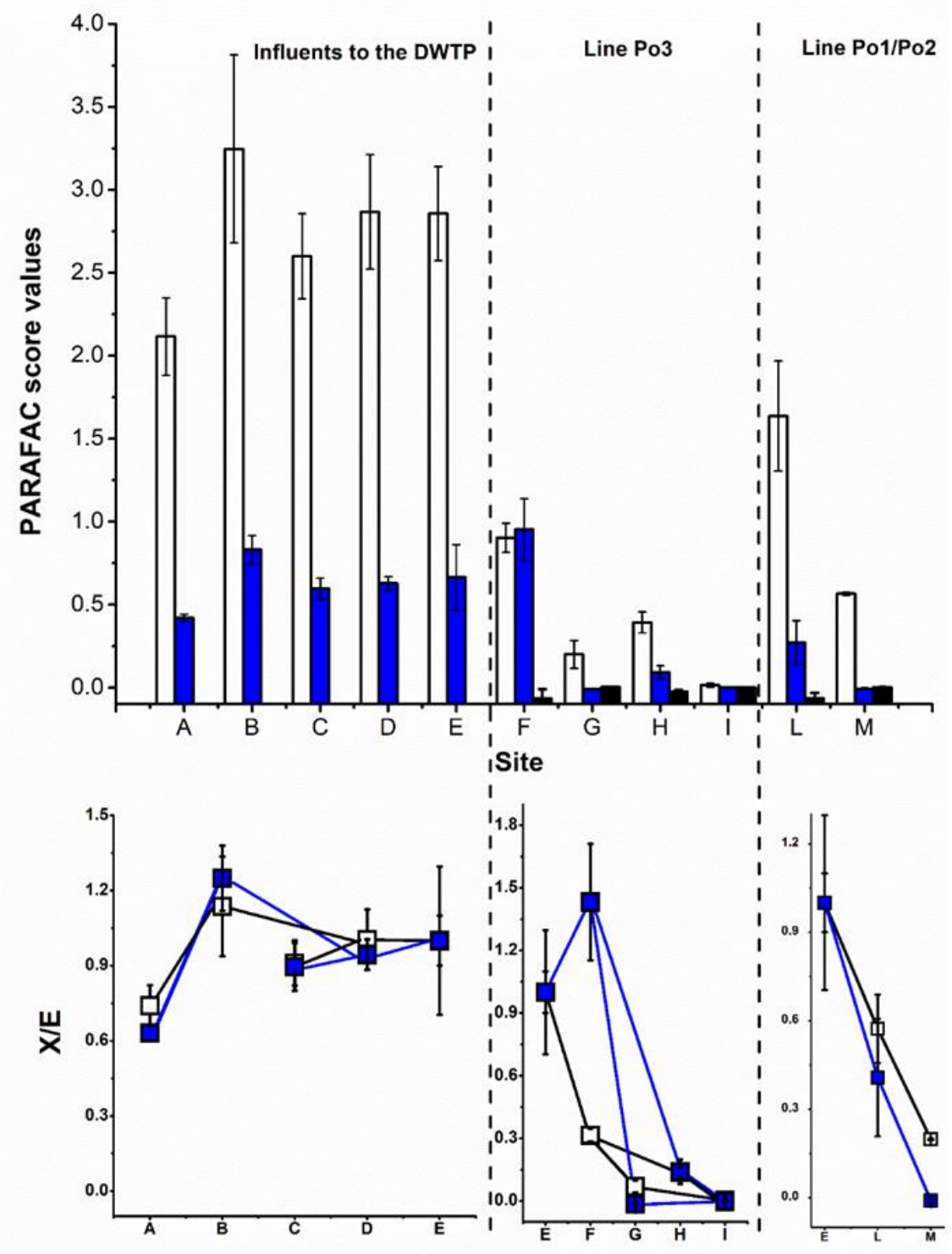

Figure 4.49. PARAFAC components evolution along the DWTP, white columns for HA-L components (C1), blue for Try-L (C2) and black for Tyr-L (C3). As insert below, the change of PARAFAC score values (normalized), taking the values from site $E$ as initial. HA-L represented by white squares ( $\square$ ) and Try-L by blue squares ( $\square)$. Tyr-L were not represented in the latter. Error bars were calculated as the standard deviation between replicates.

\subsection{Characterization of the inlet effluents of the DWTP (sites A to E)}

In the lagoon inlet (site A), HA-L had a lower fluorescence signal than at the outlet (site B), and the same was observed for Try-L ones. The influents had score values of $2.1 \pm 0.2$ of HA-L and $0.42 \pm 0.02$ of Try-L, respectively, and after lagooning process, they increased up to $3.2 \pm 0.6$ of HA-L and $0.83 \pm 0.09$ of Try-L. These observations might be attributed to organic matter derived from algae growth or the biodegradation of protein-like substances, whose by-products emit as HA-L and Try-L, resulting in an overall fluorescence increment for 
these two [223]. Comparable levels of these types of DOM were detected in raw river water (site C), being $2.6 \pm 0.3$ and $0.60 \pm 0.06$ for HA-L and Try-L, respectively. As expected, in the spot where the lagoon outlet and Po river are mixed (site D), the HA-L and Try-L scores were the average between the ones from sites $\mathrm{B}$ and $\mathrm{C}$, being $2.9 \pm 0.3$ for HA-L and $0.63 \pm 0.04$ for Try-L.

As mentioned in 4.6.2.1, from site D water goes through a static horizontal flow presettling basin (equipped with a rotary dredge for the mechanical removal of sludge) where coagulants and flocculants are used in order to promote the sedimentation process. At the outlet of the pre-settling basin (site E), the treatment plant is divided into the two treatment lines, Po1/Po2 and Po3. As reported by other authors [224], DOM is generally unaffected by this process, in agreement with PARAFAC score values remaining constant between sites D and E.

\subsection{Treatment line Po3 (sites F to I)}

In the samples from the ozonation treatment (site F), a $68 \%$ reduction of HA-L score values was observed, showing that this process is efficient to remove this type of substances. Contrarily, Try-L scores exhibited a $25 \%$ increment compared to site E. A plausible explanation could be that certain fraction from HA-L oxidation by-products might be alike to (or emit in the same region than) Try-L substances [126,131].

After the ozonation process, the water goes to the three CYCLOFLOC clarifiers (sites $\mathrm{H}$ and $\mathrm{G}$ ). As described in section 4.6.2.1, only in the basin $\mathrm{G}$ there is an additional chlorination process, resulting in a slightly higher overall fluorescence decay than in H. Po3 outlet (site I), which concerns water ready for distribution to the city and consumption, effectively had negligible levels of DOM.

\subsection{Treatment line Pol/Po2 (sites $L$ and $M$ )}

After chlorination processes (with $\mathrm{NaClO}$ and $\mathrm{ClO}_{2}$, site L), score values from HA-L and Try-L decayed a 43 and 59\%, respectively, compared to site E. Interestingly, when correlating these results with the ones from ozonation in Po3, the set of by-products were clearly different: whereas for ozonation a plausible transformation from HA-L into Try-L was observed, in samples obtained from the site L, an indistinct decrease for both components was evidenced. These results can be explained by taking into account that $\mathrm{ClO}_{2}$ and $\mathrm{ClO}^{-}$are less selective than $\mathrm{O}_{3}$, which normally shows a clear preference towards double bonds, thus favouring the 
conversion of $\mathrm{C} 1$ into $\mathrm{C} 2$. At the final stage of this treatment line (site $\mathrm{M}$ ), the outflow had negligible levels of Try-L substances, but considerable for HA-L ones $(0.566 \pm 0.008)$, contrarily to the treatment line Po3 final outflow (site I).

\subsubsection{UVa and NPOC measurements}

As previously mentioned, HA-L and Try-L scores exhibited a decay along the treatment process, showing the expected highest values at the DWTP inlet points (A to D of Figure 4.47A) and decreasing, at different levels, in each treatment step as described in the previous section. For the overall treatment line Po1/Po2, HA-L scores exhibited a decay from inlet point, site $\mathrm{D}$, to the outlet, site $\mathrm{M}$, of ca. $80 \%$, whereas at the end of treatment line Po3, site I, HA-L were not detected at all (Figure 4.49). Try-L scores were negligible either at $\mathrm{M}$ or I.

Although without knowing the type of DOM that was being degraded, a comparable trend was also observed with the UVa measurements (Figure 4.50A). The site D exhibited an UVa of $4 \pm 1 \mathrm{~m}^{-1}$, being of $1.0 \pm 0.4 \mathrm{~m}^{-1}$ after treatment line Po1/Po2 in site $\mathrm{M}$ (ca. $75 \%$ absorbance decay), and $0.38 \pm 0.02 \mathrm{~m}^{-1}$ after treatment line Po3 in site I (ca. 90\% absorbance decay). However, and differently from EEM-PARAFAC, the UVa had a significant decay after the sedimentation process (site E), whereas HA-L or Try-L score values remained constant from D to E (Figure 4.49), thus indicating that colloidal organic matter and/or the non-fluorescent one, is lost in this step, as deducted in the previous section.

On the other hand, NPOC results have shown only an average value around $1250 \mu \mathrm{g} / \mathrm{L}$, only observing a reduction of 40-50\%, approximately, at the final effluent from each treatment line, being of $(6.6 \pm 0.9) \times 10^{2} \mu \mathrm{g} / \mathrm{L}$ at the site $\mathrm{I}$, and $(7.8 \pm 0.7) \times 10^{2} \mu \mathrm{g} / \mathrm{L}$ at site $\mathrm{M}$.
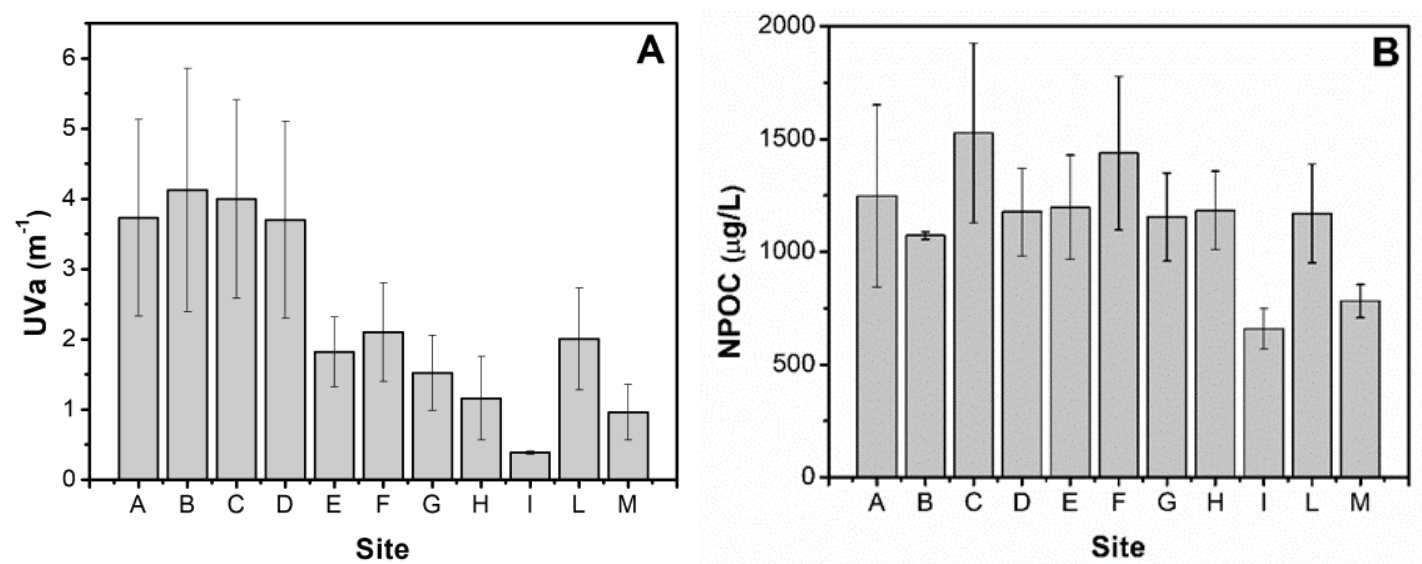

Figure 4.50. Obtained values in each sampling point for: A) UVa; B) NPOC. Values represent the average of consecutive measurements, and error bars the associated uncertainty.

\subsubsection{Conclusions}


EEM-PARAFAC was successfully applied to track and characterize DOM at almost trace level along the DWTP of Turin, Italy, providing information about the types of DOM and plausible chemical reactions happening along the DWTP. The trends of HA-L and Try-L score values were agreement with UVa measurements. NPOC was the less sensitive technique, and changes were only observed when comparing the inlet and the outlet of each treatment line. Therefore, even though NPOC, and especially UVa, are useful methodologies in DWTP to rapidly check the DOM behaviour along with the plant, only EEM-PARAFAC was able to properly track the behaviour of the different types of DOM and provided deeper layers of information regarding chemical changes.

To sum up, EEM-PARAFAC should be deployed in routine for DWTP water quality analysis. Moreover, in future works, EEM and toxicological changes towards HA-L and Try$\mathrm{L}$ after chlorination and ozonation, as well as the correlation with the formation of trihalomethanes and other disinfection by-products, will be studied.

\subsection{A rational analysis on key parameters ruling Zerovalent Iron-based treatment train: towards the separation of reductive from oxidative phases}

Results here shown describe the work performed during the secondment at PSA, carried out under the supervision of Dr. Isabel Oller, Dr. Sara Miralles-Cuevas and Prof. Dr. Sixto Malato. The work was sent to Chemical Engineering Journal on $17^{\text {th }}$ June 2021. The list of authors is: Sciscenko, Iván; Arques, Antonio; Escudero-Oñate, Carlos; Roccamante, Melina; Ruiz-Delgado, Ana; Miralles-Cuevas, Sara; Malato, Sixto; Oller, Isabel.

\subsubsection{Introduction}

In the past three decades, studies applying AOPs as tertiary wastewater treatment have demonstrated great effectiveness in the removal of a wide range of CECs. Yet, some of them, such as nitroaromatic [211], halogenated [225] or neonicotinoids [226], exhibit slow degradation rates even with AOPs.

The feasibility of ZVI reduction/oxidation (by addition of $\mathrm{H}_{2} \mathrm{O}_{2}$ ) system has been studied towards the degradation of the model pollutant, p-nitrobenzoic acid (PNBA), at low concentration levels and applying a two-step process: a ZVI pre-treatment (reduction, R 4.10) followed by the Fenton oxidation reaction by employing commercial ZVI microparticles (mZVI). Information about nitroaromatic compounds uses, water occurrence, toxicity and remediation difficulties (both, biological and by AOPs) can be found elsewhere [227-229]. 


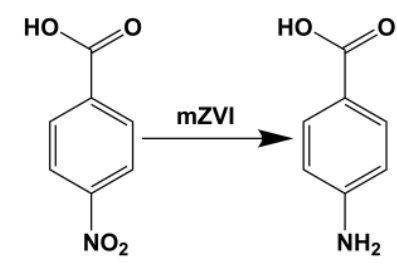

With the main objective of investigating the advantages, and lacks, for increasing the reactivity of the chosen model pollutant in a Fenton-like oxidation process by employing the above-described two-steps treatment train, the effect of dissolved oxygen, $\mathrm{pH}$, water ionic content and the initial amount of mZVI were analysed in this work. Different initial $\mathrm{H}_{2} \mathrm{O}_{2}$ concentrations were used for the subsequent Fenton process, as well as studying the light irradiation effect. A comparison between separating or not the mZVI previously to $\mathrm{H}_{2} \mathrm{O}_{2}$ addition was also assessed. In addition, consecutive reductions, as well as mZVI reusability, was also investigated. Overall, the experimental work gathered in this work might be useful to better comprehend the viability of this interesting approach (ZVI for reduction/oxidation combined system), as well as finding the best possible scenarios where efforts should be focused on for its application.

\subsubsection{Experimental}

\subsubsection{Reagents}

Model contaminants, p-nitrobenzoic acid (PNBA, $\mathrm{C}_{7} \mathrm{H}_{5} \mathrm{O}_{2} \mathrm{NO}_{2}$ ) and p-aminobenzoic acid $\left(\mathrm{PABA}, \mathrm{C}_{7} \mathrm{H}_{5} \mathrm{O}_{2} \mathrm{NH}_{2}\right)(>99 \%)$, and hydrogen peroxide $\left(\mathrm{H}_{2} \mathrm{O}_{2}\right)(35 \%$ w/w) (for Fenton reactions) were purchased from Sigma-Aldrich. $\mathrm{pH}$ was adjusted employing sodium hydroxide $(\mathrm{NaOH})$ or sulfuric acid $\left(\mathrm{H}_{2} \mathrm{SO}_{4}\right)(96 \%)$, both obtained from J. T. Baker. Ferrous ion $\left(\mathrm{Fe}^{2+}\right)$ and total iron $\left(\mathrm{Fe}_{\text {total }}\right)$ were measured employing acetic acid $\left(\mathrm{CH}_{3} \mathrm{COOH}, \mathrm{J}\right.$. T. Baker), ammonium acetate $\left(\mathrm{NH}_{4} \mathrm{CH}_{3} \mathrm{COO}\right.$, Riedel-de-Haën), 1,10-phenantroline $\left(\mathrm{C}_{12} \mathrm{H}_{8} \mathrm{~N}_{2}\right.$, Merck) and ascorbic acid $\left(\mathrm{C}_{6} \mathrm{H}_{8} \mathrm{O}_{6}\right.$, Sigma-Aldrich). Quantification of $\mathrm{H}_{2} \mathrm{O}_{2}$ was performed with titanium oxysulfate ( $\mathrm{TiOSO}_{4}$, Fluka). Water matrix effect was evaluated with the addition of sodium sulphate $\left(\mathrm{Na}_{2} \mathrm{SO}_{4}\right.$, Panreac), sodium chloride $\left(\mathrm{NaCl}\right.$, Merck) and sodium bicarbonate $\left(\mathrm{NaHCO}_{3}\right.$, Panreac). High-pressure liquid chromatography (HPLC) measurements were carried out with formic acid $(\mathrm{HCOOH})$ and HPLC-grade acetonitrile $\left(\mathrm{CH}_{3} \mathrm{CN}\right)$, both purchased from Panreac. mZVI (> 98\%) were provided by BASF.

Demineralised water (DW) and natural water (NW) (characterization for the latter is shown in Table 4.10) were used as water matrices. DW was obtained by reverse osmosis + 
electrode ionization plant located at Plataforma Solar de Almería (conductivity $<10 \mu \mathrm{S} / \mathrm{cm}$ and inorganic and dissolved organic carbon below $0.5 \mathrm{mg} / \mathrm{L}$ ).

Respective PNBA and PABA $600 \mu \mathrm{M}$ stock solutions were prepared in DW in basic media. Both were stable at dark conditions as no hydrolysis was observed.

Table 4.10. Natural water characterization.

\begin{tabular}{|c|c|}
\hline Parameter & Value \\
\hline $\mathbf{p H}$ & $7.6 \pm 0.2$ \\
\hline Conductivity $(\boldsymbol{\mu S} / \mathrm{cm})$ & $748 \pm 4$ \\
\hline Dissolved organic carbon $(\mathbf{m g} / \mathbf{L})$ & $<0.5$ \\
\hline Total inorganic carbon $(\mathbf{m g} / \mathbf{L})$ & $46 \pm 4$ \\
\hline $\mathbf{S O}_{4}{ }^{2-}(\mathbf{m g} / \mathbf{L})$ & $40 \pm 10$ \\
\hline $\mathbf{C l}^{-}(\mathbf{m g} / \mathbf{L})$ & $70 \pm 20$ \\
\hline $\mathbf{P O}_{4}{ }^{3-}(\mathbf{m g} / \mathbf{L})$ & $<0.5$ \\
\hline $\mathbf{C l O}^{-}(\mathbf{m g} / \mathbf{L})$ & $<0.02$ \\
\hline $\mathbf{C a}^{2+}(\mathbf{m g} / \mathbf{L})$ & $12 \pm 3$ \\
\hline $\mathbf{M g}^{2+}(\mathbf{m g} / \mathbf{L})$ & $14 \pm 2$ \\
\hline $\mathbf{K}^{+}(\mathbf{m g} / \mathbf{L})$ & $2.07 \pm 0.08$ \\
\hline $\mathbf{N a}^{+}(\mathbf{m g} / \mathbf{L})$ & $110 \pm 20$ \\
\hline
\end{tabular}

\subsubsection{Chemical analysis}

Total Inorganic Carbon (TIC) and total organic carbon were measured with a Shimadzu TOC-VCN. Solutions conductivity was determined with a conductivity meter Crison GLP 31 . Dissolved oxygen was measured with a Horiba LAQUA WQ-310. $\mathrm{H}_{2} \mathrm{O}_{2}$ was measured spectrophotometrically according to DIN 38402H15 method employing an Evolution 220 Thermo Scientific spectrophotometer. The latter equipment was also employed for $\mathrm{Fe}^{2+}$ and $\mathrm{Fe}_{\text {total }}$ determinations according to ISO 6332:1988. Before total carbon and spectrophotometric analyses, samples were filtered through $0.45 \mu \mathrm{m}$ Nylon Millipore filter.

Ion chromatography was applied for anions and cations determination (Metrohm 850 Professional IC with Metrohm 872 Extension Module 1 and 2). For cations analyses, a Metrosep C4-250/4.0 column $(5 \mu \mathrm{m}, 4.0 \times 250 \mathrm{~mm})$ was used, with an isocratic flow of the mobile phase, a solution of acetone (9\%), nitric acid $2 \mathrm{M}(0.085 \%)$ and pyridine $(0.75 \%)$. As for anions' analysis, a Metrosep A Trap1-100/4.0 column (570 $\mu \mathrm{m}, 4.0 \times 100 \mathrm{~mm})$ was used, and the mobile phase consisted of a $\mathrm{NaCO}_{3} 5 \mathrm{mM}$ solution injected with a gradient flow.

PNBA and PABA were monitored with an HPLC Agilent 1100 series equipped with UVDAD detector and C18 analytical column (Phenomenex - Luna $5 \mu \mathrm{m} 100 \AA$ A). $9 \mathrm{~mL}$ of sample were filtered through $0.2 \mu \mathrm{m}$ PTFE Millipore filter and mixed with $1 \mathrm{~mL} \mathrm{CH}_{3} \mathrm{CN}$. Analytes were eluted with an isocratic flow of $0.5 \mathrm{~mL} / \mathrm{min}$ of $80 \% \mathrm{HCOOH}(25 \mathrm{mM})$ and $20 \% \mathrm{CH}_{3} \mathrm{CN}$ 
and measured with fixed wavelengths of 265 and $275 \mathrm{~nm}$ for PNBA and PABA, respectively (detection limit $0.25 \mu \mathrm{M}$ in both cases).

\subsubsection{Experimental procedure}

Pre-reductive reactions were carried out in an open batch reactor containing $1 \mathrm{~L}$ of PNBA as the target pollutant. Two initial concentrations of PNBA were used $(6$ and $60 \mu \mathrm{M})$ thus simulating two possible scenarios; the lowest simulating the concentrations found in urban wastewater effluents, and the highest simulating highly polluted waters. $\mathrm{pH}$ was adjusted to 3.0, 5.0 or 7.0 with $\mathrm{H}_{2} \mathrm{SO}_{4}$ or $\mathrm{NaOH} 1 \mathrm{M}$ when needed, and mZVI $(0.056,0.56,1.4,2.8$ and $4.2 \mathrm{~g} / \mathrm{L}$ ) was added directly afterwards under continuous stirring. To study the effect of $\mathrm{O}_{2}$, the same procedure as above was followed but with previous $\mathrm{N}_{2}$ purging ( 5 minutes of $\mathrm{N}_{2}$ bubbling before adding $\mathrm{mZVI}$ ). Regarding the anions effect, $\mathrm{SO}_{4}{ }^{2-}, \mathrm{Cl}^{-}$and $\mathrm{HCO}_{3}{ }^{-}$salts were added to DW until obtaining similar conductivity as NW, requiring $400 \mathrm{mg} / \mathrm{L}$ of $\mathrm{Na}_{2} \mathrm{SO}_{4}, 350 \mathrm{mg} / \mathrm{L}$ of $\mathrm{NaCl}$ and $700 \mathrm{mg} / \mathrm{L}$ of $\mathrm{NaHCO}_{3}$. Afterwards, $\mathrm{H}_{2} \mathrm{SO}_{4} 1 \mathrm{M}$ was added to reach $\mathrm{pH} 3.0$ and then $1.4 \mathrm{~g} / \mathrm{L}$ of mZVI were added to the solution.

Fenton reactions were performed in two different ways: in one case by adding $50 \mathrm{mg} / \mathrm{L}$ of $\mathrm{H}_{2} \mathrm{O}_{2}$ directly inside the reactor containing the mZVI, and in the other one, by first waiting for the $\mathrm{mZVI}$ decantation and transferring the supernatant $(800 \mathrm{~mL})$ to an analogous reactor previous $\mathrm{H}_{2} \mathrm{O}_{2}(10,25$ and $50 \mathrm{mg} / \mathrm{L})$ addition. In the second case, mZVI reusability $\left(\mathrm{pH}_{0} 3.0\right.$ and 7.0) was carried out with the $200 \mathrm{~mL}$ remaining in the bottom of the reactor with the $\mathrm{mZVI}$ that could not be separated, and topping up with $800 \mathrm{~mL}$ of PNBA. As an individual case, for the mZVI reuse at pH 7.0, photo-Fenton (carried out in a solar simulator Atlas Suntest XLS+, USA) was also tested. The system was always agitated with a magnetic stirrer. The experimental procedure followed is represented in the scheme of Figure 4.51.

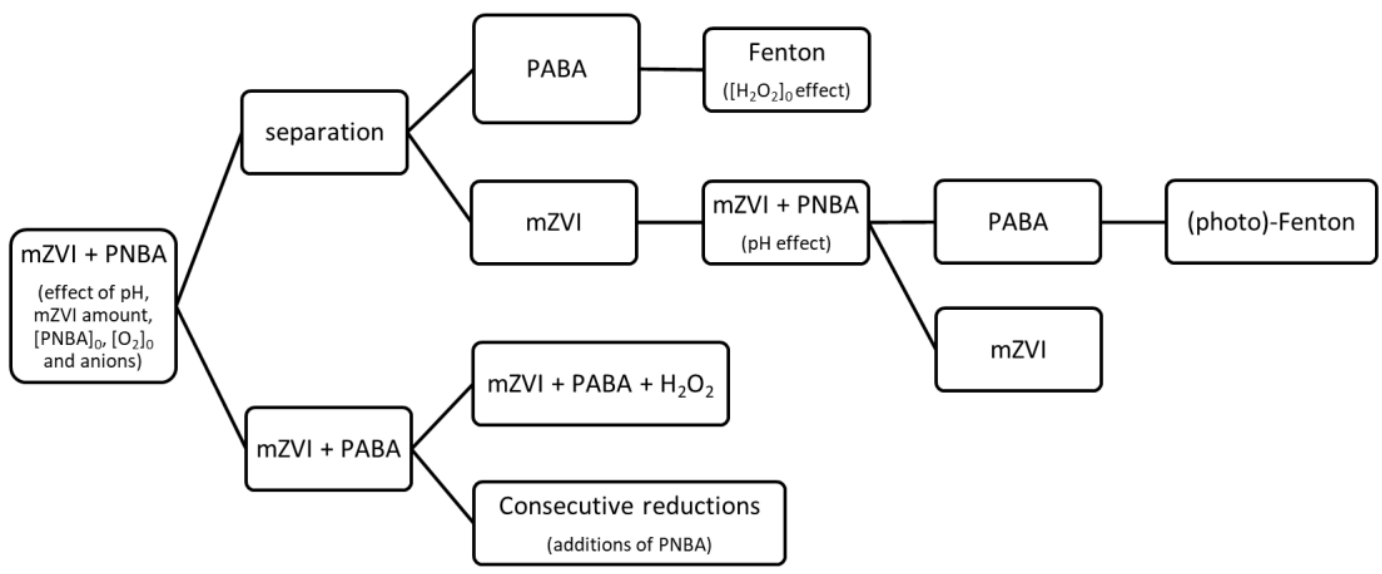

Figure 4.51. Summary of the studied processes in this work. 


\subsubsection{Results and discussion}

\subsubsection{Pre-reductive step}

\subsection{Concentration of micro ZVI and $p H$ effect}

Firstly, the effect of the initial amount of mZVI was explored in the range $0.056-4.2 \mathrm{~g} / \mathrm{L}$ at pH 3.0 in NW (Figure 4.52). Results indicated that only when mZVI was $\geq 1.4 \mathrm{~g} / \mathrm{L}, 6 \mu \mathrm{M}$ of PNBA was efficiently reduced. However, the further addition of mZVI did not result in a significant enhancement of the reductive process. This issue could be attributed to the parallel reactions of mZVI with water (see R 1.35 and $\mathrm{R} 1.36$, section 1.6), which compete with the redox process involving the pollutant ( $\mathrm{R} 4.10)$; only when there is enough mZVI availability, pollutant reduction occurs. As predicted by reactions $\mathrm{R} 1.35$ and $\mathrm{R} 1.36$, a fast $\mathrm{pH}$ increment was observed, reaching its final value in the first $5 \mathrm{~min}$ and remaining constant after up to 180 min. When using 0.056 and $0.56 \mathrm{~g} / \mathrm{L}$ of $\mathrm{mZVI}, \mathrm{pH}$ reached 5.5 in both cases, whereas from 1.4 to $4.2 \mathrm{~g} / \mathrm{L}$, it attained 7.5 to 8.0 .

Dissolved $\mathrm{Fe}_{\text {total }}$ concentration levels at the end of the assay were considerably high, 27 $\mathrm{mg} / \mathrm{L}$ at $180 \mathrm{~min}$ when starting with the minimum mZVI quantity of $0.056 \mathrm{~g} / \mathrm{L}, 30 \mathrm{mg} / \mathrm{L}$ for $0.56 \mathrm{~g} / \mathrm{L}$ of mZVI, $40 \mathrm{mg} / \mathrm{L}$ for $1.4 \mathrm{~g} / \mathrm{L}$ of mZVI, $43 \mathrm{mg} / \mathrm{L}$ for $2.8 \mathrm{~g} / \mathrm{L}$ of mZVI and $45 \mathrm{mg} / \mathrm{L}$ with $4.2 \mathrm{~g} / \mathrm{L}$ of $\mathrm{mZVI}$. Moreover, in all cases, no significant differences were observed between $\mathrm{Fe}^{2+}$ and aforementioned $\mathrm{Fe}_{\text {total }}$ concentrations, indicating negligible $\mathrm{Fe}^{3+}$ presence.

Since mZVI consumes $\mathrm{O}_{2}$ (e.g. reactions $\mathrm{R} 1.14$, R 1.36 and $\mathrm{R} 1.37$, section 1.6), due to the high amount of mZVI, anaerobic conditions can be rapidly reached (> $99 \%$ of $\mathrm{O}_{2}$ consumption in 2 minutes, remaining constant until the end of the assay, see Figure 4.53), thus explaining the high $\mathrm{Fe}^{2+}$ concentration values - and negligible $\mathrm{Fe}^{3+}$ ones-leached at neutral $\mathrm{pH}[230]$.

$$
\begin{aligned}
& 4 \mathrm{Fe}^{2+}+4 \mathrm{H}^{+}+\mathrm{O}_{2} \rightarrow 4 \mathrm{Fe}^{3+}+2 \mathrm{H}_{2} \mathrm{O} \\
& \mathrm{Fe}^{0}+2 \mathrm{H}^{+} \rightarrow \mathrm{Fe}^{2+}+\mathrm{H}_{2} \uparrow \\
& 2 \mathrm{Fe}^{0}+2 \mathrm{H}_{2} \mathrm{O}+\mathrm{O}_{2} \rightarrow 2 \mathrm{Fe}^{2+}+4 \mathrm{OH}^{-} \\
& \mathrm{Fe}^{0}+2 \mathrm{H}^{+}+\mathrm{O}_{2} \rightarrow \mathrm{Fe}^{2+}+\mathrm{H}_{2} \mathrm{O}_{2}
\end{aligned}
$$



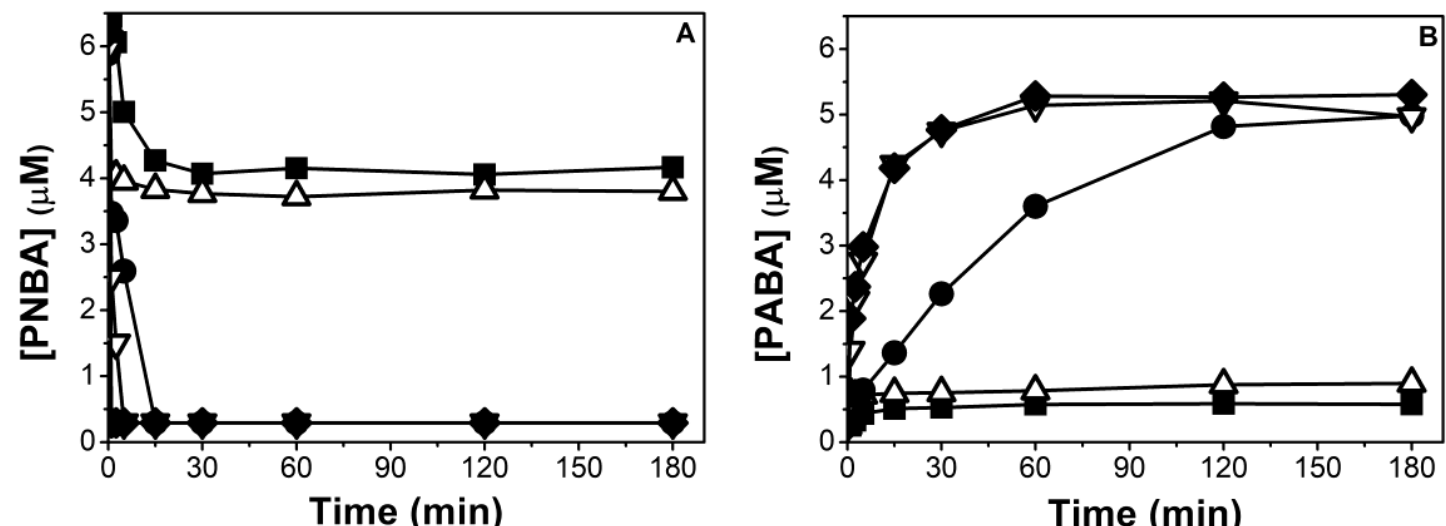

Figure 4.52. PNBA reduction $(\mathrm{A})$ and generated PABA $(B)$ in $\mathrm{NW}$ at $\mathrm{pH} 3.0$ with different amounts of mZVI $(\mathrm{g} / \mathrm{L}): 0.056(\bullet), 0.56(\Delta), 1.4(\bullet), 2.8(\nabla)$ and $4.2(\diamond)$.

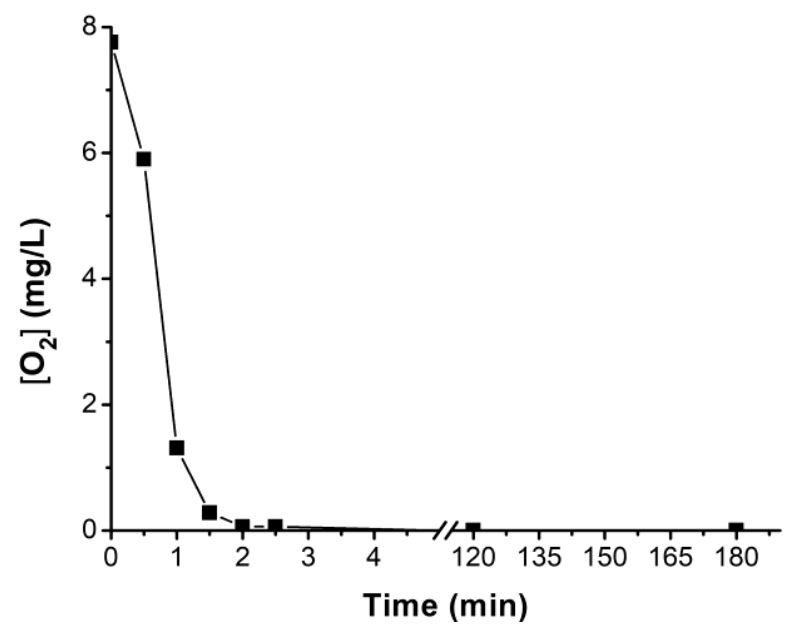

Figure 4.53. Dissolved oxygen concentration during PNBA $6 \mu \mathrm{M}$ reduction in NW with $1.4 \mathrm{~g} / \mathrm{L} \mathrm{of} \mathrm{mZVI}$ at initial pH 3.0.

PNBA $(6 \mu \mathrm{M})$ reduction was also studied at $\mathrm{pH} 5.0$ and 7.0 with $1.4 \mathrm{~g} / \mathrm{L}$ of $\mathrm{mZVI}$ in NW. In sharp contrast, incomplete reductions were obtained, attaining 23\% PNBA removal in 180 min at $\mathrm{pH} 5.0$ and negligible at $\mathrm{pH} 7.0$ (data not shown). This can be explained by the enhanced iron corrosion that occurs at acidic vs. neutral media, which in turns favours pollutant reduction [78].

The experiment was repeated $(\mathrm{pH}=3.0,1.4 \mathrm{mg} / \mathrm{L}$ of $\mathrm{mZVI}, \mathrm{NW})$ but adding three consecutive doses of PNBA $6 \mu \mathrm{M}$. Interestingly, complete PNBA reduction was observed in each cycle, despite the initial $\mathrm{pH}$ was not corrected, and hence, it was systematically above 7 (Figure 4.54). Different reasons must be considered simultaneously to explain this behaviour: i) activation of $\mathrm{mZVI}$ with the first treatment at $\mathrm{pH} 3.0$ removing the iron oxides passive layer, thus having more exposed $\mathrm{Fe}^{0}[231]$, ii) the $\mathrm{O}_{2}$ was rapidly consumed (Figure 4.53), enhancing the reductive process (see later Figure 4.56), and iii) the likelihood generation of magnetite $\left(\mathrm{Fe}_{3} \mathrm{O}_{4}\right)$ and/or $\mathrm{Fe}^{3+}$ (oxy)hydroxides with adsorbed $\mathrm{Fe}^{2+}$, which are also well known to easily reduce nitroaromatic compounds at neutral $\mathrm{pH}$ [232-234]. 


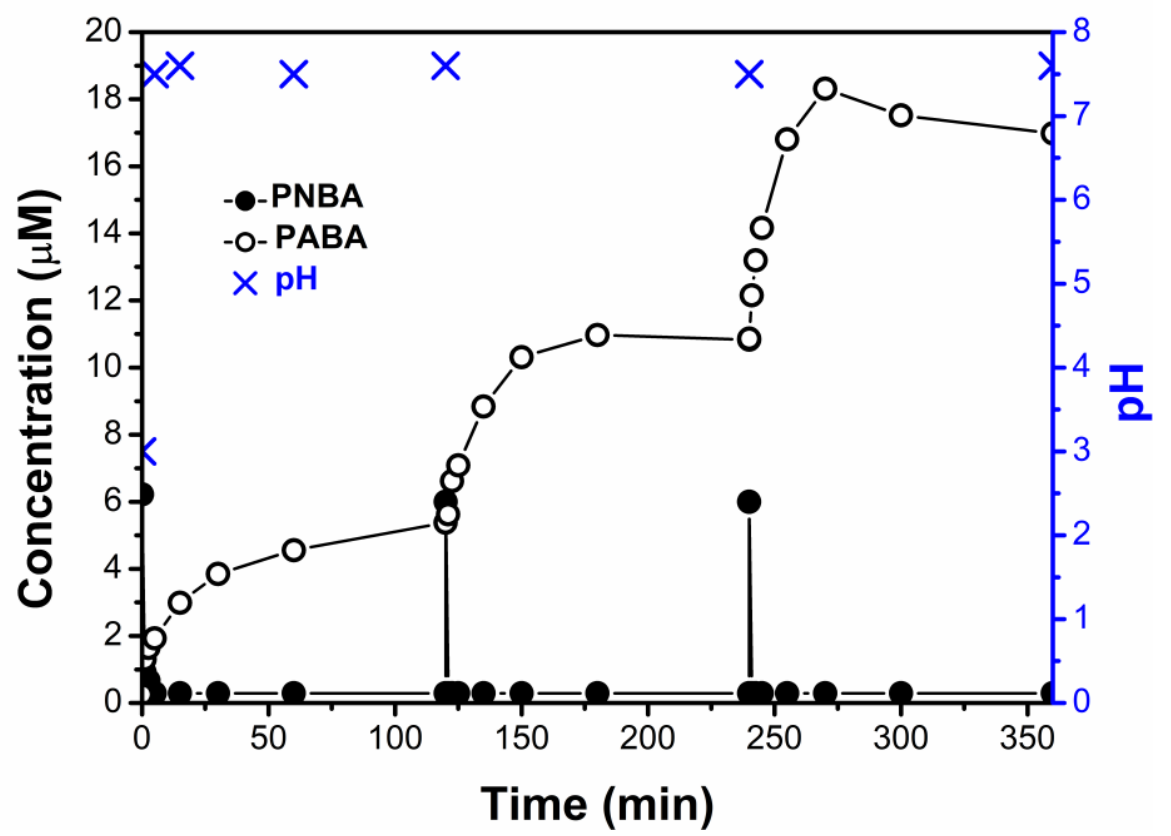

Figure 4.54. Three consecutive reductions of PNBA $6 \mu \mathrm{M}$ (additions each $120 \mathrm{~min}$ ) in NW with $1.4 \mathrm{~g} / \mathrm{L} \mathrm{of}$ mZVI and initial pH 3.0.

Finally, it is important to indicate that the initial concentration of PNBA did not play an important role in the studied range, as comparable results were obtained when selected reactions were performed with $60 \mu \mathrm{M}$ of PNBA ( $\mathrm{pH}=3.0, \mathrm{ZVI}=1.4 \mathrm{~g} / \mathrm{L}$ and NW as matrix).

\subsection{Water matrix and $\mathrm{O}_{2}$ effect}

When DW was employed (PNBA $6 \mu \mathrm{M}$, pH 3.0, $1.4 \mathrm{~g} / \mathrm{L} \mathrm{mZVI}$ ) an incomplete removal was obtained, reaching a fast $50 \%$ of PNBA elimination in ca. $2.5 \mathrm{~min}$, but followed by a very slow decay up to $2.3 \mu \mathrm{M}$ in $180 \mathrm{~min}$ (Figure 4.56A). Therefore, NW matrix favoured the reductive process.

Water ionic constitution effect has long been studied for different target pollutants as it involves many complex reactions, explaining the discrepancy reported for pollutant removal with ZVI. Therefore, to investigate which anion might be the main responsible for improving PNBA reduction in NW, the individual effect of $\mathrm{SO}_{4}{ }^{2-}, \mathrm{Cl}^{-}$and $\mathrm{HCO}_{3}{ }^{-}$was studied, all of them added into DW as sodium salts until reaching conductivity of $750 \mu \mathrm{S} / \mathrm{cm}$, which was that of NW (Table 4.10).

As shown in Figure 4.56, no significant differences in reduction of PNBA, or generation of PABA, were observed between DW with and without $270 \mathrm{mg} / \mathrm{L}$ of $\mathrm{SO}_{4}{ }^{2-}$. With $212 \mathrm{mg} / \mathrm{L}$ of $\mathrm{Cl}^{-}$, a slight inhibition was observed (PNBA 3.5 $\mu \mathrm{M}$ and PABA $0.6 \mu \mathrm{M}$ final concentrations). Only when employing $508 \mathrm{mg} / \mathrm{L}$ of $\mathrm{HCO}_{3}{ }^{-}$(remaining a TIC content of $34 \mathrm{mg} / \mathrm{L}$ after $\mathrm{pH}$ adjustment to 3.0, shortly before mZVI addition), rapid PNBA reduction occurred, achieving 
the detection limit ( $>96 \%$ of PNBA reduction) in ca. 2.5 min and obtaining ca. $2.5 \mu \mathrm{M}$ PABA formation in the same period, which was 12 times faster than the one obtained in NW $(2.5 \mu \mathrm{M}$ of PABA in 30 min, Figure 4.52B).

These results are in agreement with the iron corrosion obtained, being at the end of each experiment $\left(180 \mathrm{~min}\right.$ ) the lowest dissolved $\mathrm{Fe}_{\text {total }}$ value of $22 \mathrm{mg} / \mathrm{L}$ with $\mathrm{NaCl}$, and the highest one, $80 \mathrm{mg} / \mathrm{L}$, when adding $\mathrm{NaHCO}_{3}$ (Figure 4.55A), also in agreement with other previously reported works [235,236]. Besides, since the initial $\mathrm{pH}$ was 3.0, it is also known that dissolved $\mathrm{CO}_{2}$ can also accelerate ZVI corrosion [236,237]. In line with these statements, TIC of NW at $\mathrm{pH} 3.0$ was $10 \mathrm{mg} / \mathrm{L}$, hence, having intermediate iron corrosion $\left(\mathrm{Fe}_{\text {total }}=40 \mathrm{mg} / \mathrm{L}\right)$, and thus also an intermediate PNBA reduction rate, between $\mathrm{DW}$ and $\mathrm{DW}+\mathrm{HCO}_{3}{ }^{-}$.
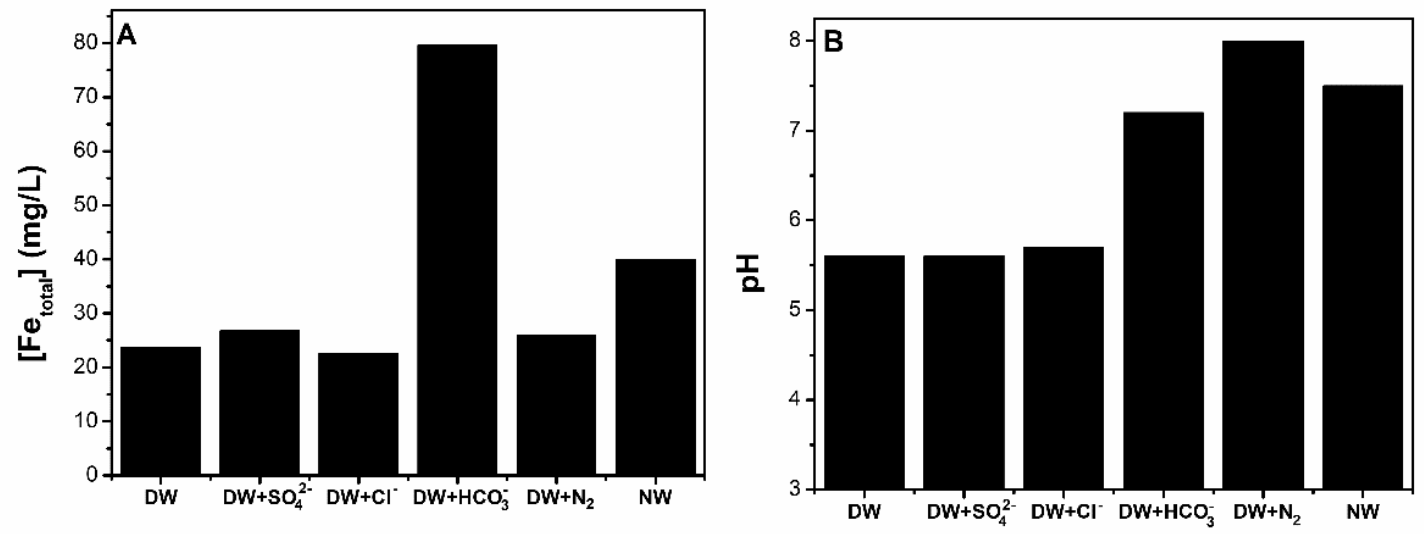

Figure 4.55. PNBA $6 \mu \mathrm{M}$ reduction at initial $\mathrm{pH} 3.0$ with $1.4 \mathrm{~g} / \mathrm{L} \mathrm{mZVI}$ in different water matrices at 180 min: A) released $\mathrm{Fe}$ (measured as total and filtered) $\mathrm{B}$ ) $\mathrm{pH}$.

Regarding the effect of $\mathrm{O}_{2}$, an almost instant and complete reduction of PNBA in DW was obtained when removing it by purging the reaction mixture with $\mathrm{N}_{2}$. This reaction rate could not even be achieved, as stated above, with aerobic NW, where the final PABA concentration was $5 \mu \mathrm{M}$ instead of $6 \mu \mathrm{M}$ (Figure 4.52B). This mass balance defect was explained when performing a blank experiment with PABA $6 \mu \mathrm{M}$ in presence of $1.4 \mathrm{~g} / \mathrm{L} \mathrm{mZVI}$ in NW under aerobic and anaerobic conditions. PABA concentration in anoxic NW remained constant for $180 \mathrm{~min}$, whereas it decayed $1 \mu \mathrm{M}$ under aerobic conditions.

It is important to highlight that under anaerobic conditions and at initial acidic $\mathrm{pH}$, reaction $\mathrm{R} 1.35$ is mainly governing the $\mathrm{mZVI} / \mathrm{H}_{2} \mathrm{O}$ system, whereas when $\mathrm{O}_{2}$ is present, reactions R 1.14 and R 1.36 gain relevance. In this last case, the generated $\mathrm{Fe}^{3+}$ eventually leads to rapid iron (oxy)hydroxide formation and species such as hematite $\left(\mathrm{Fe}_{2} \mathrm{O}_{3}\right)$, goethite $(\mathrm{FeOOH})$ and ferric hydroxide $\left(\mathrm{Fe}(\mathrm{OH})_{3}\right)$ are produced [61]. Consequently, PABA could be adsorbed as well as the mZVI surface passivated, thus stopping the PNBA reduction. These 
findings are also in agreement with the observed $\mathrm{pH}$ values achieved by the system. In a DWaerobic system, the $\mathrm{pH}$ at the end of the process was 5.5, whereas for DW-anaerobic was 8.0 (Figure 4.55B), which could be attributed to the aforementioned negligible $\mathrm{Fe}^{3+}$ hydrolysis contribution for the last case.
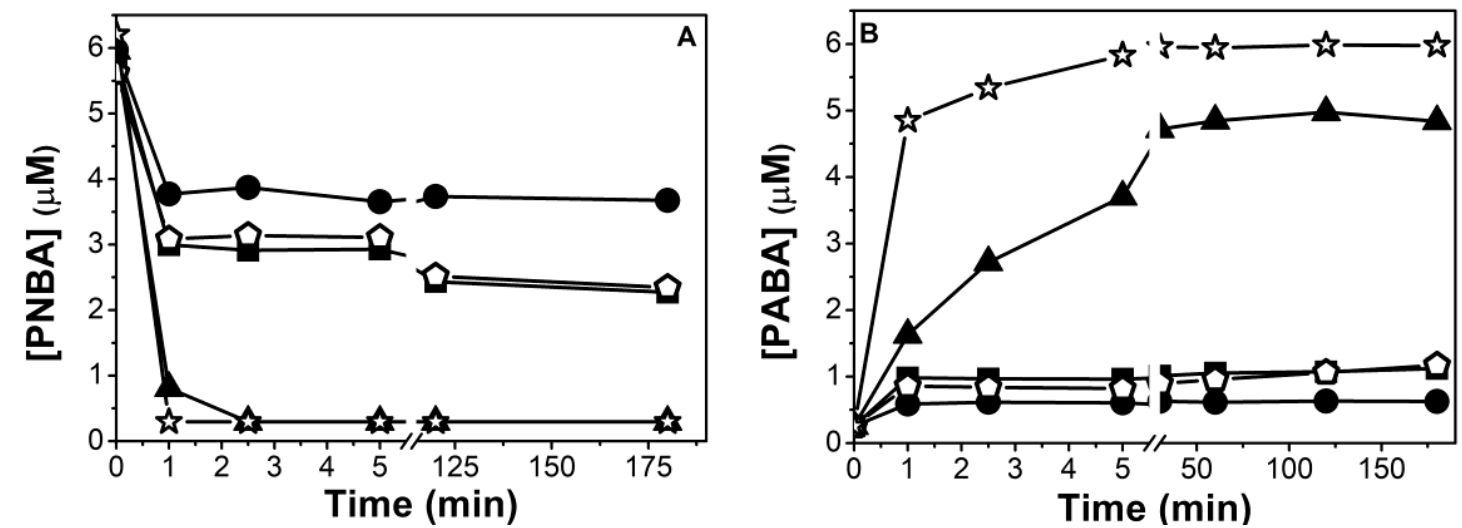

Figure 4.56. Water matrix effect. PNBA $6 \mu \mathrm{M}$ reduction with $\mathrm{mZVI} 1.4 \mathrm{~g} / \mathrm{L}$ at initial $\mathrm{pH} 3.0 \mathrm{in} \mathrm{DW}, \mathrm{A})$ PNBA and B) PABA kinetics, respectively. Symbols are represented by: DW alone $(\triangle), D W+\mathrm{Cl}^{-212} \mathrm{mg} / \mathrm{L}$ $(\bullet), \mathrm{DW}+\mathrm{SO}_{4}{ }^{2-} 270 \mathrm{mg} / \mathrm{L}(\bullet), \mathrm{DW}+\mathrm{TIC} 34 \mathrm{mg} / \mathrm{L}(\Delta)$, and DW+N 2 purging (艺).

On the other hand, it is reported that in-situ Fenton oxidation might also happen under aerobic conditions in a mZVI/ $\mathrm{H}_{2} \mathrm{O}$ system (reactions $\mathrm{R} 1.37, \mathrm{R} 1.17, \mathrm{R} 1.18$ and $\mathrm{R} 1.39$ ) [100,238], which could be degrading in some extent the formed PABA. In fact, non-identified peaks were observed within the chromatograms only during the aerobic reduction. The areas of the aforementioned by-products were plotted in Figure 4.57.

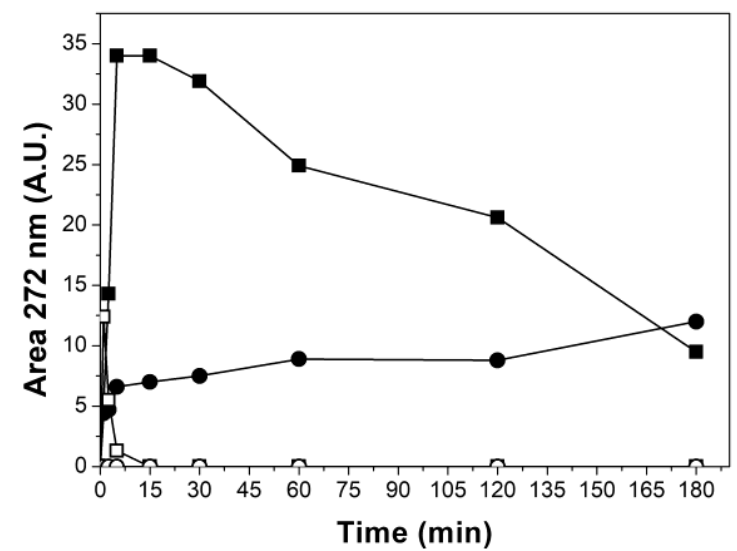

Figure 4.57. Kinetic formation of two unknown compounds, called X1 and X2, observed in the chromatograms during PNBA $6 \mu \mathrm{M}$ reduction with $1.4 \mathrm{~g} / \mathrm{L} \mathrm{mZVI}$ at initial pH 3.0 in DW under aerobic ( $\bullet$ and $\bullet$ for $X 1$ and X2, respectively) and anaerobic ( $\square$ and $\circ$ for X1 and X2, respectively) conditions.

In order to evaluate if Fenton reaction was taking place among the own reductive stage, a test with PNBA $6 \mu \mathrm{M}$ in aerobic DW containing $\mathrm{CH}_{3} \mathrm{CN} 10 \mathrm{mM}$ (as $\mathrm{HO} \bullet$ quencher) was done, not exhibiting any significant differences with the one without it. Therefore, it was concluded that PABA oxidation by in-situ Fenton was insignificant compared to its removal 
by adsorption. Noteworthy, the unknown generated by-products should be, most likely, reduction intermediates containing the nitroso or hydroxylamine groups [239,240], just formed and consumed faster under anoxic conditions.

$$
\begin{aligned}
& \mathrm{Fe}^{2+}+\mathrm{H}_{2} \mathrm{O}_{2} \rightarrow \mathrm{Fe}^{3+}+\mathrm{HO}^{\bullet}+\mathrm{OH}^{-} \\
& \mathrm{Fe}^{3+}+\mathrm{H}_{2} \mathrm{O}_{2} \rightarrow \mathrm{Fe}^{2+}+\mathrm{HO}_{2}^{\bullet}+\mathrm{H}^{+} \\
& \mathrm{Fe}^{0}+\mathrm{H}_{2} \mathrm{O}_{2} \rightarrow \mathrm{Fe}^{2+}+2 \mathrm{OH}^{-}
\end{aligned}
$$

\subsubsection{Fenton oxidation step}

As indicated in the introduction, ZVI can also be used for pollutants oxidation in the presence of hydrogen peroxide, via Fenton or related processes. Two possible procedures were investigated: $\mathrm{i}$ ) adding the $\mathrm{H}_{2} \mathrm{O}_{2}$ in the reactor after separating the mZVI (only leached iron remained, therefore only homogeneous Fenton taking place) once finished the reductive stage, and ii) maintaining mZVI together with $\mathrm{H}_{2} \mathrm{O}_{2}$, so homogeneous (with remaining iron leached in solution) and potential heterogeneous Fenton oxidation may occur. These approaches were tested with PNBA $60 \mu \mathrm{M}, \mathrm{pH}=3.0$ and $\mathrm{mZVI}=1.4 \mathrm{~g} / \mathrm{L}$.

Regarding the first strategy, after mZVI decantation and supernatant separation (10 min), the solution exhibited a pH 7.3, dissolved $\mathrm{Fe}_{\text {total }}$ of $55 \mathrm{mg} / \mathrm{L}$, and ca. $100 \mathrm{mg} / \mathrm{L}$ of non-dissolved (without filtration) $\mathrm{Fe}_{\text {total. }}$ Three different $\mathrm{H}_{2} \mathrm{O}_{2}$ initial concentrations were studied: 10, 25 and $50 \mathrm{mg} / \mathrm{L}$, obtaining $15 \%, 71 \%$ and more than 96\% PABA removal in the first $15 \mathrm{~min}$, respectively (Figure 4.59).

With the second strategy, when performing Fenton with $50 \mathrm{mg} / \mathrm{L}$ of $\mathrm{H}_{2} \mathrm{O}_{2}$ without $\mathrm{mZVI}$ previous separation, incomplete removal of PABA was obtained $(60 \%$ in the first minute, remaining constant afterwards). Moreover, a much faster $\mathrm{H}_{2} \mathrm{O}_{2}$ consumption was also observed. Whereas for the separation strategy a $52 \%$ of initial $\mathrm{H}_{2} \mathrm{O}_{2} 50 \mathrm{mg} / \mathrm{L}$ was consumed in 1 min, in presence of the mZVI was $>99 \%$ (Figure 4.58), justified mainly by reaction R 1.39. 


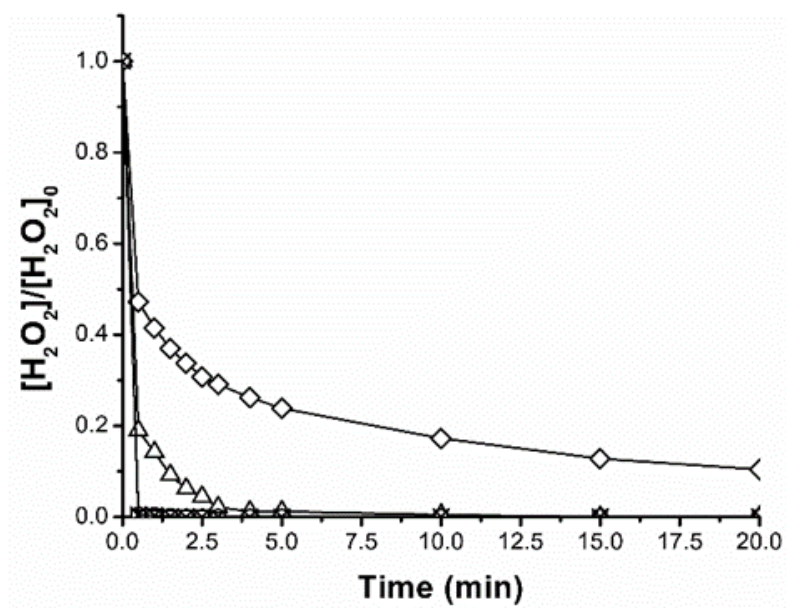

Figure 4.58. $\mathrm{H}_{2} \mathrm{O}_{2}$ consumption during Fenton oxidation experiments, separating the mZVI previous different $\mathrm{H}_{2} \mathrm{O}_{2}$ concentrations, $10 \mathrm{mg} / \mathrm{L}(\odot), 25 \mathrm{mg} / \mathrm{L}(\Delta)$ and $50 \mathrm{mg} / \mathrm{L}(\diamond)$, as well as the one containing the $\mathrm{mZVI} 1.4 \mathrm{~g} / \mathrm{L}$ with $\mathrm{H}_{2} \mathrm{O}_{2} 50 \mathrm{mg} / \mathrm{L}(\oplus)$.

Therefore, by means of $\mathrm{H}_{2} \mathrm{O}_{2}$ consumption and PABA degradation percentage, the most efficient overall PNBA removal was obtained with a first pre-reductive step, the subsequent mZVI separation, and the Fenton homogeneous oxidation at the end. In any case, the reformation of PNBA when performing the Fenton reaction was detected.

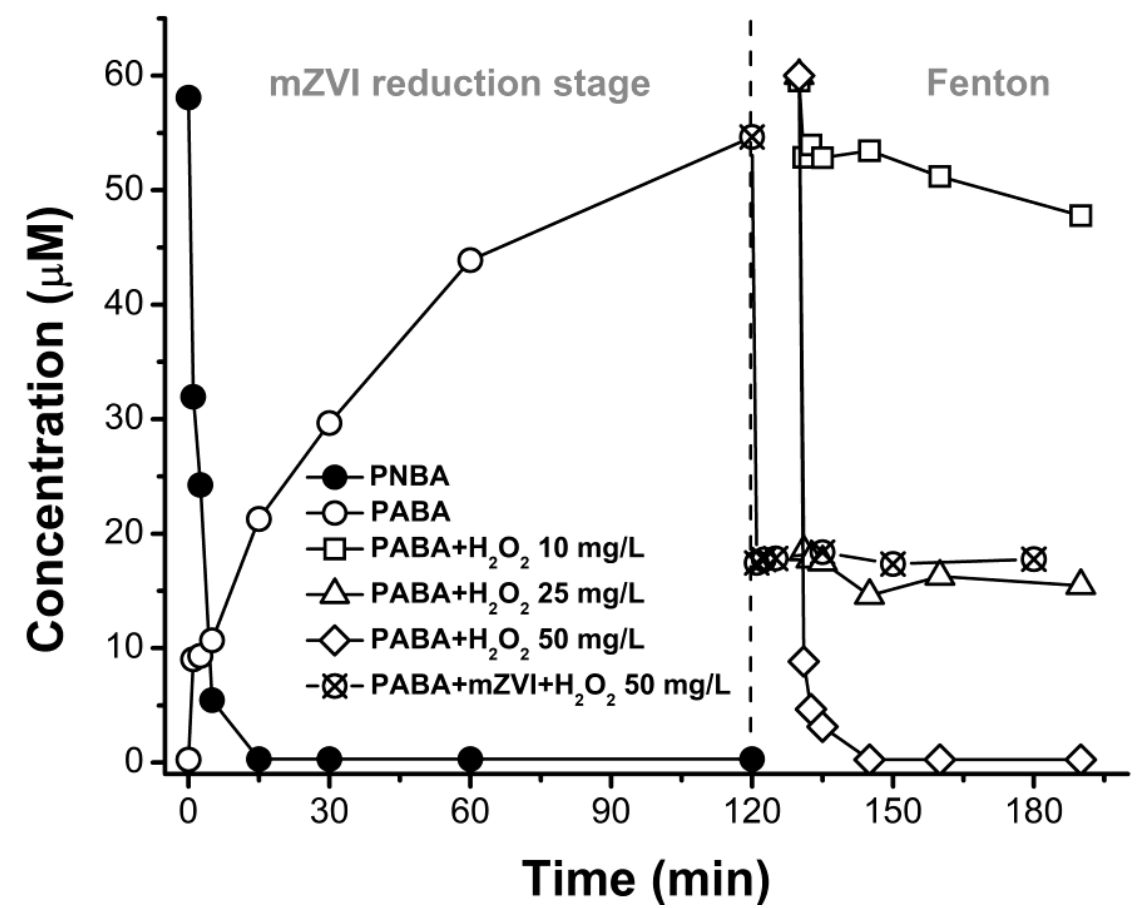

Figure 4.59. Reduction of PNBA $60 \mu \mathrm{M}$ in NW at initial pH 3.0 with $1.4 \mathrm{~g} / \mathrm{L} \mathrm{of} \mathrm{mZVI}$, followed by the different tested Fenton oxidations. When needed, $10 \mathrm{~min}$ for $\mathrm{mZVI}$ separation took place.

Finally, to prove that the pre-reduction step actually enhanced PNBA reactivity, the oxidative Fenton process (with previous mZVI separation system) was also carried out with an additional $60 \mu \mathrm{M}$ of PNBA (i.e. the supernatant with the formed PABA ca. $60 \mu \mathrm{M}$ from the previous reduction, and the intentionally added PNBA $60 \mu \mathrm{M}$ ). The data presented in Figure 
4.60 confirms the aforementioned hypothesis, being the PNBA degradation rate almost three times slower than the one of PABA. These results are in agreement with the published $\mathrm{HO}^{\bullet}$ kinetic rate constants (KPNBA-HO $2.6 \times 10^{9} \mathrm{M}^{-1} \mathrm{~s}^{-1}$ and $\mathrm{kPABA}-\mathrm{HO} \bullet 8.2 \times 10^{9} \mathrm{M}^{-1} \mathrm{~s}^{-1}$ ) [62].

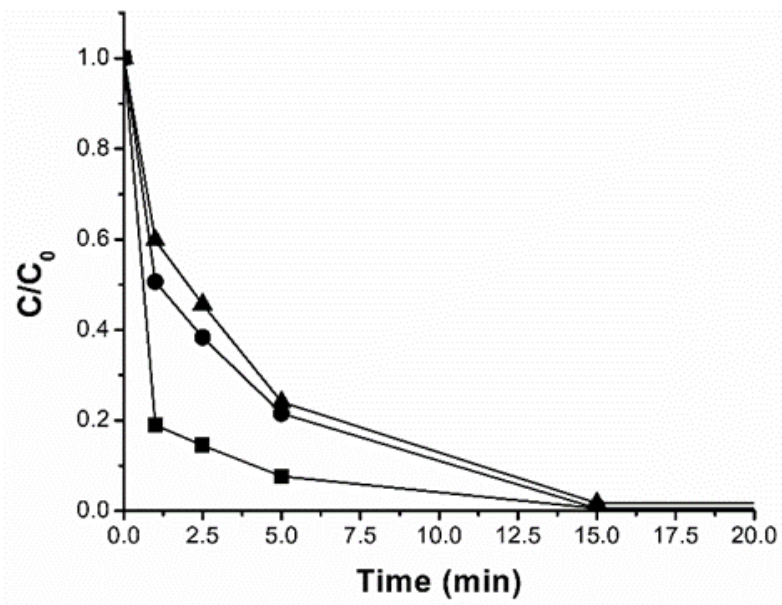

Figure 4.60. Fenton oxidation of the supernatant $\left([\mathrm{PABA}]=50 \mu \mathrm{M},\left[\mathrm{Fe}_{\text {total }}\right]=\mathbf{5 5} \mathrm{mg} / \mathrm{L}, \mathrm{pH}=7.3\right)$ with 50 $\mathrm{mg} / \mathrm{L}$ of $\mathrm{H}_{2} \mathrm{O}_{2}$, and $50 \mu \mathrm{M}$ of PNBA (added). Theorical PNBA degradation rate[62] has been also inserted in the graph. Symbol representation has been given by: $\square$ (PABA), • (PNBA) and $\triangle$ (theorical PNBA degradation rate).

\subsubsection{3.mZVI reusability}

As an additional advantage of mZVI separation after the pre-reduction step, it could be mentioned its plausible reusability. Therefore, after one complete PNBA $60 \mu \mathrm{M}$ reduction and mZVI separation from the solution, its reusability was investigated with a new PNBA $60 \mu \mathrm{M}$ solution in NW. This assay was performed not only at initial $\mathrm{pH} 3.0$ but also at initial $\mathrm{pH}$ 7.0. Interestingly, a second complete reduction was successfully achieved in $60 \mathrm{~min}$ for both cases, regardless of the initial $\mathrm{pH}$ (Figure 4.61A). These results are in line with previously discussed successive reductions (Figure 4.54), indicating that mZVI requires only a first acidic treatment to be efficient at neutral $\mathrm{pH}$.

When continuing with the subsequent Fenton oxidation, only with the reuse after the first pre-reduction at $\mathrm{pH} 3.0$, fast and complete PABA removal was obtained (almost total in 30 min), whereas with the reuse after pre-reduction at $\mathrm{pH}$ 7.0, negligible PABA degradation was observed. This issue was due to the iron lixiviation occurring within the first step. Only when the reductive phase was carried out under acidic conditions, dissolved leached iron was high enough $\left(\mathrm{Fe}_{\text {total }}=55 \mathrm{mg} / \mathrm{L}\right.$, Figure 4.61B $)$ to make the subsequent Fenton oxidation efficient enough. On the contrary, when starting the pre-reduction step at $\mathrm{pH} 7.0$, dissolved leached iron was only $5 \mathrm{mg} / \mathrm{L}$, hence, not observing any PABA degradation. 

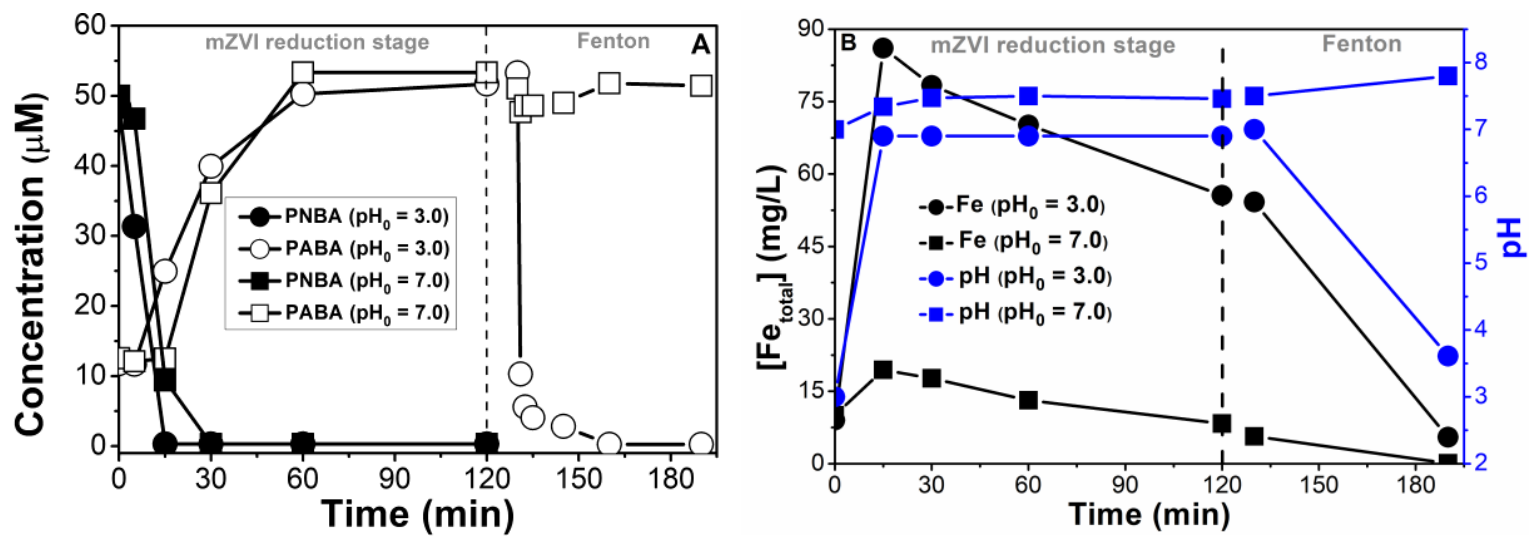

Figure 4.61. mZVI reuse for new PNBA $60 \mu \mathrm{M}$ solutions prepared in $\mathrm{NW}$ with initial pH 3.0 and 7.0.10 min for mZVI separation previous $\mathrm{H} 20250 \mathrm{mg} / \mathrm{L}$ addition in the subsequent Fenton step: A) PNBA decay and PABA formation; B) total dissolved iron and $\mathrm{pH}$ are also shown.

Interestingly, mZVI reusability at $\mathrm{pH} 7.0$ could maintain PNBA reduction, without provoking the PABA formation rate to decrease. Figure 4.62 shows three mZVI successful reusing cycles after the first activation at $\mathrm{pH} 3$ and without requiring further $\mathrm{pH}$ modifications. As previously discussed in section 3.1.1, this should also be attributed not only to the passive layer removal but also to the formation of $\mathrm{Fe}^{2+}-\mathrm{Fe}^{3+}$ oxides which can also reduce nitroaromatic compounds at neutral $\mathrm{pH}[234]$.

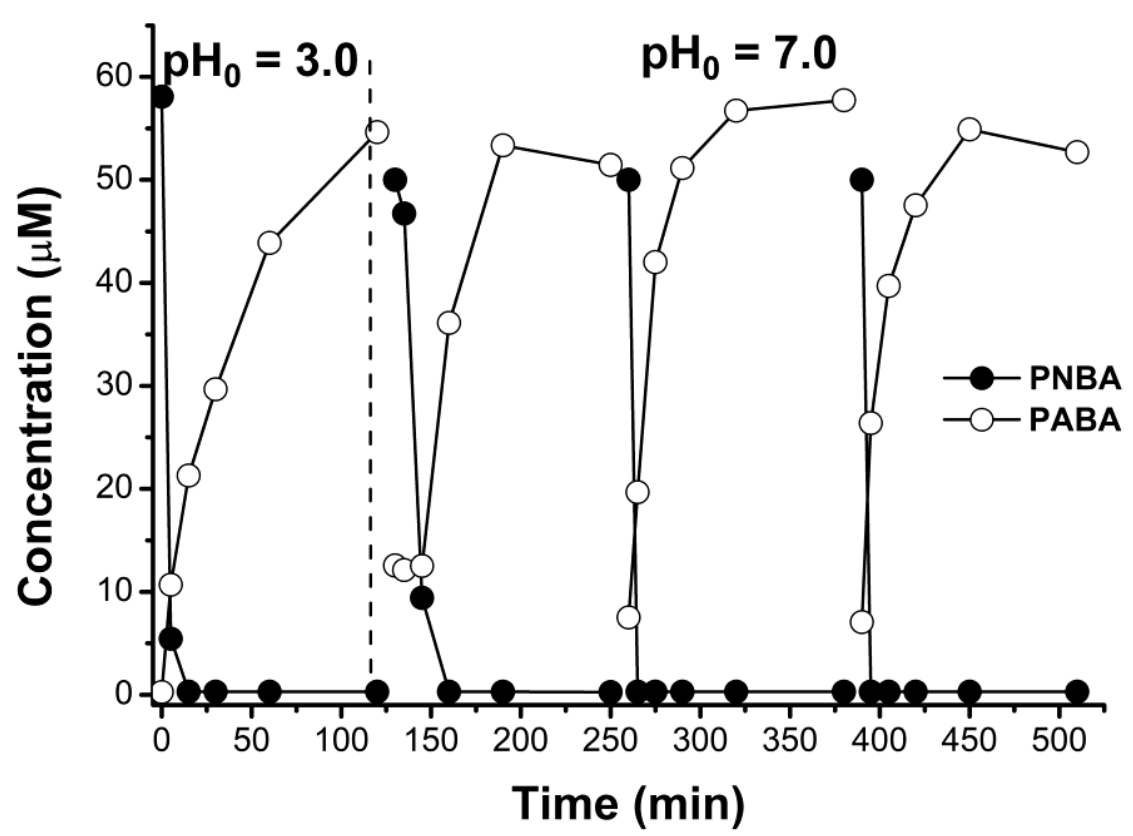

Figure 4.62. First PNBA 60 $\mu \mathrm{M}$ reduction at $\mathrm{pH} 3.0$ with $1.4 \mathrm{~g} / \mathrm{L}$ of $\mathrm{mZVI}$ in $\mathrm{NW}$, and its subsequent reuses at pH 7.0. $10 \mathrm{~min}$ between each cycle was required for $\mathrm{mZVI}$ decantation and supernatant separation.

Finally, due to the negligible PABA Fenton oxidation with reused $\mathrm{mZVI}$ at $\mathrm{pH} 7.0$ with PNBA $60 \mu \mathrm{M}$, the same experiment was fully replicated with an initial PNBA concentration of $6 \mu \mathrm{M}$. PABA degradation was now slightly higher than with the system of $60 \mu \mathrm{M}(15 \%$ in 120min). Moreover, although the dissolved $\mathrm{Fe}_{\text {total }}$ was low, the colloidal iron was still 
significant (43 mg/L of $\mathrm{Fe}_{\text {total }}$ ), so the photo-Fenton process employing simulated sunlight in a solar simulator was also investigated. Nevertheless, no significant differences compared to dark conditions were observed (results not shown).

\subsubsection{Conclusions}

A combined reductive/oxidative sequential treatment with commercial mZVI was tested towards the removal of PNBA from water at different operating conditions. $\mathrm{pH}$ 3.0, high bicarbonate concentrations and the absence of $\mathrm{O}_{2}$ notably improved PNBA pre-reduction step and PABA formation. Besides, the subsequent Fenton oxidation step showed a better performance when mZVI was previously separated for attaining complete PABA oxidation, with also markedly lowered $\mathrm{H}_{2} \mathrm{O}_{2}$ consumption.

Noteworthy, several drawbacks were also observed. Due to parallel reactions with $\mathrm{H}_{2} \mathrm{O}$ and $\mathrm{O}_{2}$, a minimum amount of $1.4 \mathrm{~g} / \mathrm{L} \mathrm{mZVI}$ was required to obtain complete PNBA reductions, which is very high considering CEC concentrations $(\mathrm{ng}-\mu \mathrm{g} / \mathrm{L})$ normally present in effluents of municipal wastewater treatment plants. Secondly, $\mathrm{pH} 3.0$ was needed to initially reduce PNBA and so to obtain a high residual amount of dissolved iron to ensure an efficient Fenton oxidation within the second step -which, at the same time, generated iron sludge-. In this regard, even though PNBA reduction at neutral $\mathrm{pH}$ was possible, low iron corrosion was achieved, and therefore, the subsequent Fenton oxidation was not possible anymore.

Possible solutions to the aforementioned drawbacks could be purging $\mathrm{N}_{2}$ along the prereduction step to reduce the required amount of mZVI, and then re-acidification, or adding an iron-chelating agent, for improving the oxidative (photo)-Fenton step. Proposed modifications to the combined reduction/oxidation mZVI system must be analyzed from a Life Cycle Assessment perspective to decide their potential and possibly interesting applications.

In conclusion, this approach might be limited to few scenarios, such as highly polluted wastewater containing outstanding levels $(\mathrm{mg}-\mathrm{g} / \mathrm{L})$ of reducible contaminants (nitroaromatic, dyes or halogenated), as well as acidic $\mathrm{pH}$, which could be the case of some industries, such as, textile or explosive manufacturers. It can be a plausible alternative for this niche application, replacing the ZVI by $\mathrm{Fe}(\mathrm{II})-\mathrm{Fe}(\mathrm{III})$ oxides couple system, without separating the catalyst previous to $\mathrm{H}_{2} \mathrm{O}_{2}$ addition, hence, being easier to produce reduction at neutral $\mathrm{pH}$ as well as avoiding iron sludge issues in the Fenton step. In such a case, ZVI immobilization in supports should be likely considered. 



\section{CHAPTER 5}

CONCLUSIONS 



\section{Conclusions}

Regarding the principal objectives of this PhD Thesis, we can conclude that:

- FQs are photolabile pollutants, being the zwitterionic speciation form (majoritarian within $\mathrm{pH}=6.5-8.0$ ) the one with the highest photolytic rate constants. It is worth mentioning that compared to ENR, CIP or SAR, those containing electron donor groups binding the aromatic ring (OFL and FLU), and/or without piperazine moiety (OA) were significantly more stable against photodegradation.

- Iron-FQ mutual co-existence significantly affect the antibiotic photolytic fate. Particularly for ENR, it was observed that the formed complex with $\mathrm{Fe}^{3+}$ (stable within the $\mathrm{pH}$ range of $3.0-7.5$ ) notably decreases the antibiotic photolytic rate constants at acid and neutral conditions. When $\mathrm{H}_{2} \mathrm{O}_{2}$ is present, the photo-Fenton process occurs, being observed even at $\mathrm{pH}$ 7.0. $\mathrm{Fe}^{\mathrm{III}}-\mathrm{ENR}_{3}$ also exhibited a slightly lower production of ROS than the non-binding FQ. Moreover, it was observed that iron might inhibit FQs photo-induced decarboxylation, contrarily to other iron-carboxylate complexes where decarboxylation is enhanced. In this regard, iron remains in solution after $2 \mathrm{~h}$ of irradiation at $\mathrm{pH} 7.0$ since the formed photoproducts are able to still chelate iron. Photoproduct formation is also $\mathrm{pH}-$ dependent, observing higher defluorination and decarboxylation at $\mathrm{pH} 7.0$ than at pH 3.0.

- It might be interesting to study the effect of different concentrations of $\mathrm{Fe}^{3+}$ on the photolysis of a mixture of FQs, also in more realistic concentrations $(0.1-1$ $\mu \mathrm{M})$. It can be anticipated that some FQs might show direct photolysis inhibition (as the one observed for ENR), but the other can show an enhancement since the complexes might be different from one another (by means of stoichiometry and stability constants).

- Magnox/UVC (heterogeneous photocatalysis) was employed for ENR abatement with a $45 \mathrm{~L}$ pilot plant scale, whose operational parameters were firstly adjusted analysing the decolourization of rhodamine-B dye, and its effectiveness compared to other AOPs. The fastest ENR removals with highest mineralization levels when performing degradations at $\mathrm{pH} 2.8$ were obtained only with photo- 
Fenton treatment. At natural $\mathrm{pH}$ (ca. 7.6), $\mathrm{H}_{2} \mathrm{O}_{2} / \mathrm{UVC}$ was the most efficient process. Nevertheless, this work should include in the future removals of trace amounts of FQs (and other CECs) with WWTP effluent as water matrix, as well as analysing the recovery and subsequent re-use of the tested magnetic photocatalyst.

- FQs degradation by (solar-)photo-Fenton was efficient at every tested water matrix (MQ, TW, SW or SWW) and $\mathrm{pH}$ (3.0 to 7.5), reaching fast degradations (> 60\% at $2 \mathrm{~h}$ maximum in the slowest case). On the other hand, only for ultrapure water at $\mathrm{pH} 3.0$ and 5.0 the mineralization was considerable $(50-80 \%$ in 2 $\mathrm{h})$, being negligible in all the other cases ( $<20 \%$ in $2 \mathrm{~h}$ ). Therefore, even though FQs interact with iron, thus obtaining significant removals at neutral $\mathrm{pH}$ conditions in absence of any external chelating agent, there is still a relevant release of oxidation by-products.

- We have concluded that the trend of mZVI treatment trains might not be suitable for CECs abatement due to required working conditions: high amount of mZVI and acidic $\mathrm{pH}$, with the subsequent considerable formed iron sludge. However, improvements such as catalyst immobilization, or mZVI replacement by iron oxides containing $\mathrm{Fe}^{2+}$ (e.g. $\mathrm{Fe}_{3} \mathrm{O}_{4}$ or $\mathrm{Fe}_{2} \mathrm{O}_{3}$ with adsorbed $\mathrm{Fe}^{2+}$ ) might be worth to try it.

Regarding the use of EEM-PARAFAC, we have demonstrated-barely for the first time - that the use of this tool is suitable for FQs (individual and mixtures) degradation analysis, at least for the research and development field. This application could be extrapolated to other areas studying FQs (photo)chemical processes, such as medicine or their synthesis, as well as for the degradation of other fluorescent CECs. For the latter, pollutants with a higher fluorescence quantum yield than FQs, detection limits within the $\mathrm{ng}-\mu \mathrm{g} / \mathrm{L}$ range should be easily achieved. Overall, EEM-PARAFAC is a sensitive, simple and easily accessible analytical tool that can show a fast picture of the situation happening during a given chemical reaction involving fluorescent compounds. Particularly we can mention that:

- EEM-PARAFAC allowed us to simultaneously track, and with detection limits of ca. $10 \mu \mathrm{g} / \mathrm{L}$ (ca. $0.03 \mu \mathrm{M}$ ), all the fluorescent compounds present in the reactor: parent pollutants, by-products and interferences (DOM from SWW and the intentionally added TBZ). 
- It was common in all cases the formation of a reaction intermediate with a EEM fingerprint comparable to the one of ENR and CIP, but with maximum shifts of ca. $20-40 \mathrm{~nm}$ above and below (red and blue shifts, respectively). In this regard, PARAFAC also allows the accurate deconvolution, and subsequent measurement, of extremely similar compounds' fingerprints (as it was the case of ENR and SAR).

- EEM-PARAFAC was correlated with HPLC-UV/Vis and mineralization results. In addition, PARAFAC components trends agreed with the antibiotic activity ones. In this regard, it might be interesting to also extrapolate this approach to FQ-resistance bacteria development studies.

- A correlation between FQs EEM changes with mass spectrometry analysis will be performed in the future. This issue is important to demonstrate all the previous hypotheses made related to FQs structural plausible modifications. Moreover, FQs degradation tracked by EEM-PARAFAC shall be also performed within the $0.01-0.1 \mu \mathrm{M}$ range, which is closer to real conditions.

- Towards its use for DOM monitoring, humic acid-like and tryptophan-like substances were easily measured at trace levels among a DWTP different treatment steps. Whereas the sedimentation step did not produce a significant DOM decrease, advanced treatments, such as ozonation and chlorination, had. Noteworthy, a correlation with DBP formation might be of interest to include it in the work. 



\section{CHAPTER 6}

REFERENCES 



\section{6. $\quad$ References}

[1] World Population Prospects - Population Division - United Nations, (n.d.). https://population.un.org/wpp/Graphs/Probabilistic/POP/TOT/900 (accessed November $17,2020)$.

[2] "World Bank. 2001. The World Bank Annual Report 2001 :Volume 1. Year in Review. Washington, DC. (c) World Bank. https://openknowledge.worldbank.org/handle/10986/13933 License: CC BY 3.0 IGO.," (n.d.). http://hdl.handle.net/10986/13933.

[3] UNESCO, The United Nations World Water Development Report 2019 -Leaving no one behind, UNESCO, Paris, 2019.

[4] Water Use and Stress - Our World in Data, (n.d.). https://ourworldindata.org/water-usestress (accessed November 17, 2020).

[5] Wall Street is about to start trading water for the first time | Living, (n.d.). https://www.euronews.com/living/2020/12/08/is-trading-water-the-next-big-thing-onwall-street (accessed January 18, 2021).

[6] European Commission, Would you drink your wastewater?, 2012. https://doi.org/10.2779/86573.

[7] A.D. Levine, T. Asano, Peer Reviewed: Recovering Sustainable Water from Wastewater, Environ. Sci. Technol. 38 (2004) 201A-208A. https://doi.org/10.1021/es040504n.

[8] M.A. Shannon, P.W. Bohn, M. Elimelech, J.G. Georgiadis, B.J. Mariñas, A.M. Mayes, Science and technology for water purification in the coming decades, Nature. 452 (2008) 301-310. https://doi.org/10.1038/nature06599.

[9] J.C. Intriago, F. López-Gálvez, A. Allende, G.A. Vivaldi, S. Camposeo, E. Nicolás Nicolás, J.J. Alarcón, F. Pedrero Salcedo, Agricultural reuse of municipal wastewater through an integral water reclamation management, J. Environ. Manage. 213 (2018) 135-141. https://doi.org/10.1016/j.jenvman.2018.02.011.

[10] V. Novoa, R. Ahumada-Rudolph, O. Rojas, K. Sáez, F. de la Barrera, J.L. Arumí, Understanding agricultural water footprint variability to improve water management in 
$\begin{array}{llllll}\text { Chile, } & \text { Sci. } & \text { Total } & \text { Environ. } & 670 & \text { (2019) }\end{array}$ https://doi.org/10.1016/j.scitotenv.2019.03.127.

[11] M.M. Mekonnen, A.Y. Hoekstra, The green, blue and grey water footprint of crops and derived crop products, Value Water Res. Rep. Ser. 2 (2010). http://www.crcnetbase.com/doi/10.1201/b13434-63.

[12] EPA, Guidlines for water reuse, Guidel. Water Reuse. (2012).

[13] JRC, Minimum quality requirements for water reuse in agricultural irrigation and aquifer recharge, 2017. https://doi.org/10.2760/887727.

[14] K.M.G. Mostofa, C. Liu, M.A. Mottaleb, G. Wan, H. Ogawa, D. Vione, T. Yoshioka, F. Wu, Dissolved Organic Matter in Natural Waters, in: K.M.G. Mostofa, T. Yoshioka, A. Mottaleb, D. Vione (Eds.), Biogeochemistry, Springer Berlin Heidelberg, Berlin, Heidelberg, 2013: pp. 1-137. https://doi.org/10.1007/978-3-642-32223-5_1.

[15] J.A. Leenheer, J.P. Croué, Characterizing aquatic dissolved organic matter, Environ. Sci. Technol. 37 (2003) 18A-26A. https://doi.org/10.1017/S0033822200003672.

[16] S.D. Richardson, M.J. Plewa, E.D. Wagner, R. Schoeny, D.M. DeMarini, Occurrence, genotoxicity, and carcinogenicity of regulated and emerging disinfection by-products in drinking water: A review and roadmap for research, Mutat. Res. - Rev. Mutat. Res. 636 (2007) 178-242. https://doi.org/10.1016/j.mrrev.2007.09.001.

[17] L.A. Weinrich, P.K. Jjemba, E. Giraldo, M.W. LeChevallier, Implications of organic carbon in the deterioration of water quality in reclaimed water distribution systems, Water Res. 44 (2010) 5367-5375. https://doi.org/10.1016/j.watres.2010.06.035.

[18] S.K.L. Ishii, T.H. Boyer, Behavior of reoccurring parafac components in fluorescent dissolved organic matter in natural and engineered systems: A critical review, Environ. Sci. Technol. 46 (2012) 2006-2017. https://doi.org/10.1021/es2043504.

[19] S. Derenne, T.T. Nguyen Tu, Characterizing the molecular structure of organic matter from natural environments: An analytical challenge, Comptes Rendus - Geosci. 346 (2014) 53-63. https://doi.org/10.1016/j.crte.2014.02.005.

[20] B. Petrie, R. Barden, B. Kasprzyk-Hordern, A review on emerging contaminants in wastewaters and the environment: Current knowledge, understudied areas and recommendations for future monitoring, Water Res. 72 (2015) 3-27. 
https://doi.org/10.1016/j.watres.2014.08.053.

[21] P.I. Hora, S.G. Pati, P.J. McNamara, W.A. Arnold, Increased Use of Quaternary Ammonium Compounds during the SARS-CoV-2 Pandemic and Beyond: Consideration of Environmental Implications, Environ. Sci. Technol. Lett. 7 (2020) 622-631. https://doi.org/10.1021/acs.estlett.0c00437.

[22] R.N. Carvalho, L. Ceriani, A. Ippolito, Development of the first Watch List under the Environmental Quality Standards Directive water policy, 2015. https://doi.org/10.2788/101376.

[23] Priority substances - Water - Environment - European Commission, (n.d.). https://ec.europa.eu/environment/water/waterdangersub/pri_substances.htm\#prop_2011 (accessed January 19, 2021).

[24] The European Parliament and the Council of the European Union, Directive 2013/39/EU of the European Parliament and of the Council, in: Fundam. Texts Eur. Priv. Law, Hart Publishing, 2013: pp. 1-17. https://doi.org/10.5040/9781782258674.0032.

[25] A. Pistocchi, C. Dorati, B. Grizzetti, A. Udias, O. Vigiak, M. Zanni, Water quality in Europe: effects of the Urban Wastewater Treatment Directive, (2019) 115. https://doi.org/10.2760/303163.

[26] The European Parliament and the Council of the European Union, Directive (EU) 2020/2184, EU (revised) Drinking Water Directive, Off. J. Eur. Communities. 2019 (2020) 1-62.

[27] A. Christou, G. Papadavid, P. Dalias, V. Fotopoulos, C. Michael, J.M. Bayona, B. Piña, D. Fatta-Kassinos, Ranking of crop plants according to their potential to uptake and accumulate contaminants of emerging concern, Environ. Res. 170 (2019) 422-432. https://doi.org/10.1016/j.envres.2018.12.048.

[28] T. Brodin, J. Fick, M. Jonsson, J. Klaminder, Dilute Concentrations of a Psychiatric Drug Alter Behavior of Fish from Natural Populations, Science (80-. ). 339 (2013) 814815. https://doi.org/10.1126/science.1226850.

[29] M.L. Hedgespeth, P.A. Nilsson, O. Berglund, Ecological implications of altered fish foraging after exposure to an antidepressant pharmaceutical, Aquat. Toxicol. 151 (2014) 84-87. https://doi.org/10.1016/j.aquatox.2013.12.011. 
[30] S.H. Ruiz, S. Wickramasekara, L. Abrell, X. Gao, B. Chefetz, J. Chorover, Complexation of trace organic contaminants with fractionated dissolved organic matter: Implications for mass spectrometric quantification, Chemosphere. 91 (2013) 344-350. https://doi.org/10.1016/j.chemosphere.2012.11.059.

[31] P. Verlicchi, M. Al Aukidy, E. Zambello, Occurrence of pharmaceutical compounds in urban wastewater: Removal, mass load and environmental risk after a secondary treatment-A review, Sci. Total Environ. 429 (2012) 123-155. https://doi.org/10.1016/j.scitotenv.2012.04.028.

[32] L. Rizzo, C. Manaia, C. Merlin, T. Schwartz, C. Dagot, M.C. Ploy, I. Michael, D. FattaKassinos, Urban wastewater treatment plants as hotspots for antibiotic resistant bacteria and genes spread into the environment: A review, Sci. Total Environ. 447 (2013) 345360. https://doi.org/10.1016/j.scitotenv.2013.01.032.

[33] S.R. Hughes, P. Kay, L.E. Brown, Global Synthesis and Critical Evaluation of Pharmaceutical Data Sets Collected from River Systems, Environ. Sci. Technol. 47 (2013) 661-677. https://doi.org/10.1021/es3030148.

[34] P.C. Appelbaum, P.A. Hunter, The fluoroquinolone antibacterials: Past, present and future perspectives, Int. J. Antimicrob. Agents. 16 (2000) 5-15. https://doi.org/10.1016/S0924-8579(00)00192-8.

[35] B. Hamad, The antibiotics market, Nat. Rev. Drug Discov. 9 (2010) 675-676. https://doi.org/10.1038/nrd3267.

[36] I. Ebert, J. Bachmann, U. Kühnen, A. Küster, C. Kussatz, D. Maletzki, C. Schlüter, Toxicity of the fluoroquinolone antibiotics enrofloxacin and ciprofloxacin to photoautotrophic aquatic organisms, Environ. Toxicol. Chem. 30 (2011) 2786-2792. https://doi.org/10.1002/etc.678.

[37] T. Rosen, L.L. Shen, T.J. O’Donnell, D.W.T. Chu, C.S. Cooper, A.G. Pernet, L.A. Mitscher, P.N. Sharma, Mechanism of inhibition of DNA gyrase by quinolone antibacterials: A cooperative drug-DNA binding model, Biochemistry. 28 (1989) 38863894. https://doi.org/10.1021/bi00435a039.

[38] World Health Organization, WHO list of critically important antimicrobials for human medicine (WHO CIA list) 6th Rev, World Heal. Organ. (2017). 
http://who.int/foodsafety/publications/antimicrobials-fifth/en/.

[39] L. Riaz, T. Mahmood, A. Khalid, A. Rashid, M.B. Ahmed Siddique, A. Kamal, M.S. Coyne, Fluoroquinolones (FQs) in the environment: A review on their abundance, sorption and toxicity in soil, Chemosphere. 191 (2018) 704-720. https://doi.org/10.1016/j.chemosphere.2017.10.092.

[40] L. Aristilde, G. Sposito, Binding of ciprofloxacin by humic substances: A molecular dynamics study, Environ. Toxicol. Chem. $29 \quad$ (2010) 90-98. https://doi.org/10.1002/etc.19.

[41] A. Cuprys, R. Pulicharla, S.K. Brar, P. Drogui, M. Verma, R.Y. Surampalli, Fluoroquinolones metal complexation and its environmental impacts, Coord. Chem. Rev. 376 (2018) 46-61. https://doi.org/10.1016/j.ccr.2018.05.019.

[42] V. Uivarosi, Metal complexes of quinolone antibiotics and their applications: An update, Molecules. 18 (2013) 11153-11197. https://doi.org/10.3390/molecules180911153.

[43] X. Van Doorslaer, J. Dewulf, H. Van Langenhove, K. Demeestere, Fluoroquinolone antibiotics: An emerging class of environmental micropollutants, Sci. Total Environ. 500-501 (2014) 250-269. https://doi.org/10.1016/j.scitotenv.2014.08.075.

[44] A. Albini, S. Monti, Photophysics and photochemistry of fluoroquinolones, Chem. Soc. Rev. 32 (2003) 238-250. https://doi.org/10.1039/b209220b.

[45] Z. Zhang, X. Xie, Z. Yu, H. Cheng, Influence of chemical speciation on photochemical transformation of three fluoroquinolones (FQs) in water: Kinetics, mechanism, and toxicity of photolysis products, Water Res. 148 (2019) 19-29. https://doi.org/10.1016/j.watres.2018.10.027.

[46] S. Babić, M. Periša, I. Škorić, Photolytic degradation of norfloxacin, enrofloxacin and ciprofloxacin in various aqueous media, Chemosphere. 91 (2013) 1635-1642. https://doi.org/10.1016/j.chemosphere.2012.12.072.

[47] T.G. Vasconcelos, D.M. Henriques, A. König, A.F. Martins, K. Kümmerer, Photodegradation of the antimicrobial ciprofloxacin at high $\mathrm{pH}$ : Identification and biodegradability assessment of the primary by-products, Chemosphere. 76 (2009) 487493. https://doi.org/10.1016/j.chemosphere.2009.03.022.

[48] S. Snowberger, H. Adejumo, K. He, K.P. Mangalgiri, M. Hopanna, A.D. Soares, L. 
Blaney, Direct Photolysis of Fluoroquinolone Antibiotics at $253.7 \mathrm{~nm}$ : Specific Reaction Kinetics and Formation of Equally Potent Fluoroquinolone Antibiotics, Environ. Sci. Technol. 50 (2016) 9533-9542. https://doi.org/10.1021/acs.est.6b01794.

[49] F. Bosca, A Photochemical Approach to Fluoroquinolones Toxicity, in: Adv. Mol. Toxicol., 1st ed., Elsevier B.V., 2015: pp. 259-280. https://doi.org/10.1016/B978-0-12802229-0.00007-4.

[50] B. Petrie, E.J. McAdam, J.N. Lester, E. Cartmell, Obtaining process mass balances of pharmaceuticals and triclosan to determine their fate during wastewater treatment, Sci. Total Environ. $\quad 497-498 \quad$ (2014) 553-560. https://doi.org/10.1016/j.scitotenv.2014.08.003.

[51] B.F. da Silva, A. Jelic, R. López-Serna, A.A. Mozeto, M. Petrovic, D. Barceló, Occurrence and distribution of pharmaceuticals in surface water, suspended solids and sediments of the Ebro river basin, Spain, Chemosphere. 85 (2011) 1331-1339. https://doi.org/10.1016/j.chemosphere.2011.07.051.

[52] L. Gao, Y. Shi, W. Li, H. Niu, J. Liu, Y. Cai, Occurrence of antibiotics in eight sewage treatment plants in Beijing, China, Chemosphere. 86 (2012) 665-671. https://doi.org/10.1016/j.chemosphere.2011.11.019.

[53] D.G.J. Larsson, C. de Pedro, N. Paxeus, Effluent from drug manufactures contains extremely high levels of pharmaceuticals, J. Hazard. Mater. 148 (2007) 751-755. https://doi.org/10.1016/j.jhazmat.2007.07.008.

[54] R. Gothwal, Shashidhar, Occurrence of high levels of fluoroquinolones in aquatic environment due to effluent discharges from bulk drug manufacturers, J. Hazardous, Toxic, Radioact. Waste. 21 (2017). https://doi.org/10.1061/(ASCE)HZ.21535515.0000346.

[55] H.T. Lai, J.J. Lin, Degradation of oxolinic acid and flumequine in aquaculture pond waters and sediments, Chemosphere. $75 \quad$ (2009) 462-468. https://doi.org/10.1016/j.chemosphere.2008.12.060.

[56] X. Wu, J. Zheng, H. Ding, D. Ran, W. Xu, Y. Song, J. Yang, Study on the interaction between oxolinic acid aggregates and protein and its analytical application, Anal. Chim. Acta. 596 (2007) 16-22. https://doi.org/10.1016/j.aca.2007.05.051. 
[57] S. Malato, P. Fernández-Ibáñez, M.I. Maldonado, J. Blanco, W. Gernjak, Decontamination and disinfection of water by solar photocatalysis: Recent overview and trends, Catal. Today. 147 (2009) 1-59. https://doi.org/10.1016/j.cattod.2009.06.018.

[58] I. Oller, S. Malato, J.A. Sánchez-Pérez, Combination of Advanced Oxidation Processes and biological treatments for wastewater decontamination-A review, Sci. Total Environ. 409 (2011) 4141-4166. https://doi.org/10.1016/j.scitotenv.2010.08.061.

[59] W.H. Glaze, J. Kang, H. Douglas, Ozone : Science \& Engineering The Chemistry of Water Treatment Processes Involving Ozone, Hydrogen Peroxide and Ultraviolet Radiation, Ozone Sci. Eng. (1987) 335-352. https://doi.org/https://doi.org/10.1080/01919518708552148.

[60] Convocatoria del Programa Iberoamericano de Ciencia y Tecnología para el Desarrollo (CYTED), Eliminación de Contaminantes por Fotocatálisis Heterogénea, Gráfica 12 y 50, La Plata, Argentina, 2001.

[61] J.J. Pignatello, E. Oliveros, A. MacKay, Advanced Oxidation Processes for Organic Contaminant Destruction Based on the Fenton Reaction and Related Chemistry, Crit. Rev. Environ. Sci. Technol. $36 \quad$ (2006) 1-84. https://doi.org/10.1080/10643380500326564.

[62] G. V Buxton, C.L. Greenstock, W.P. Helman, A.B. Ross, Critical Review of rate constants for reactions of hydrated electrons, hydrogen atoms and hydroxyl radicals $\left(\cdot \mathrm{OH} / \cdot \mathrm{O}^{-}\right)$in Aqueous Solution, J. Phys. Chem. Ref. Data. 17 (1988) 513-886. https://doi.org/10.1063/1.555805.

[63] U. Von Gunten, Ozonation of drinking water: Part II. Disinfection and by-product formation in presence of bromide, iodide or chlorine, Water Res. 37 (2003) 1469-1487. https://doi.org/10.1016/S0043-1354(02)00458-X.

[64] Y. Yang, J.J. Pignatello, J. Ma, W.A. Mitch, Comparison of halide impacts on the efficiency of contaminant degradation by sulfate and hydroxyl radical-based advanced oxidation processes (AOPs), Environ. Sci. Technol. 48 (2014) 2344-2351. https://doi.org/10.1021/es404118q.

[65] D.B. Miklos, C. Remy, M. Jekel, K.G. Linden, J.E. Drewes, U. Hübner, Evaluation of advanced oxidation processes for water and wastewater treatment - A critical review, 
Water Res. 139 (2018) 118-131. https://doi.org/10.1016/j.watres.2018.03.042.

[66] M.A. Oturan, J.-J. Aaron, Advanced Oxidation Processes in Water/Wastewater Treatment: Principles and Applications. A Review, Crit. Rev. Environ. Sci. Technol. 44 (2014) 2577-2641. https://doi.org/10.1080/10643389.2013.829765.

[67] M. Salimi, A. Esrafili, M. Gholami, A. Jonidi Jafari, R. Rezaei Kalantary, M. Farzadkia, M. Kermani, H.R. Sobhi, Contaminants of emerging concern: a review of new approach in AOP technologies, Environ. Monit. Assess. 189 (2017). https://doi.org/10.1007/s10661-017-6097-x.

[68] M.J. Pilling, P.W. Seakings, Reaction Kinetics, Oxford university press, 1995.

[69] D. Sasikumar, A.T. John, J. Sunny, M. Hariharan, Access to the triplet excited states of organic chromophores, Chem. Soc. Rev. 49 (2020) 6122-6140. https://doi.org/10.1039/d0cs00484g.

[70] F.A. Cotton, Chemical Applications of Group Theory, 3rd ed., John Wiley \& Sons Inc, 1990.

[71] Y. Li, J. Niu, W. Wang, Photolysis of Enrofloxacin in aqueous systems under simulated sunlight irradiation: Kinetics, mechanism and toxicity of photolysis products, Chemosphere. 85 (2011) 892-897. https://doi.org/10.1016/j.chemosphere.2011.07.008.

[72] M.L. Marin, L. Santos-Juanes, A. Arques, A.M. Amat, M.A. Miranda, Organic Photocatalysts for the Oxidation of Pollutants and Model Compounds, Chem. Rev. 112 (2012) 1710-1750. https://doi.org/10.1021/cr2000543.

[73] O. Legrini, E. Oliveros, A.M. Braun, Photochemical Processes for Water Treatment, Chem. Rev. 93 (1993) 671-698. https://doi.org/10.1021/cr00018a003.

[74] J. Mack, J.R. Bolton, Photochemistry of nitrite and nitrate in aqueous solution: A review, J. Photochem. Photobiol. A Chem. 128 (1999) 1-13. https://doi.org/10.1016/S10106030(99)00155-0.

[75] J. Martin, C. KH, J. KS, F. SE, G. RM, T. SJ, H. CN, E. VA, N. JL, C. TL, Testing the iron hypothesis in ecosystems of the equatorial Pacific Ocean, Nature. 371 (1994) 123129. http://myweb.facstaff.wwu.edu/shulld/ESCI 432/Martin1994.pdf.

[76] A. Stefánsson, Iron(III) hydrolysis and solubility at $25^{\circ} \mathrm{C}$, Environ. Sci. Technol. 41 
(2007) 6117-6123. https://doi.org/10.1021/es070174h.

[77] Coagulation and Flocculation in Water and Wastewater Treatment | IWA Publishing, (n.d.). https://www.iwapublishing.com/news/coagulation-and-flocculation-water-andwastewater-treatment (accessed May 22, 2021).

[78] J.M. Triszcz, A. Porta, F.S.G. Einschlag, Effect of operating conditions on iron corrosion rates in zero-valent iron systems for arsenic removal, Chem. Eng. J. 150 (2009) 431439. https://doi.org/10.1016/j.cej.2009.01.029.

[79] I. Sciscenko, V. Luca, C.P. Ramos, T.B. Scott, V.N. Montesinos, N. Quici, Immobilization of nanoscale zerovalent iron in hierarchically channelled polyacrylonitrile for Cr(VI) remediation in wastewater, J. Water Process Eng. 39 (2021) 101704. https://doi.org/10.1016/j.jwpe.2020.101704.

[80] H.J.H. Fenton, LXXIII.-Oxidation of tartaric acid in presence of iron, J. Chem. Soc., Trans. 65 (1894) 899-910. https://doi.org/10.1039/CT8946500899.

[81] M.I. Litter, M. Slodowicz, An overview on heterogeneous Fenton and photoFenton reactions using zerovalent iron materials, J. Adv. Oxid. Technol. 20 (2017). https://doi.org/10.1515/jaots-2016-0164.

[82] W. Huang, M. Brigante, F. Wu, C. Mousty, K. Hanna, G. Mailhot, Assessment of the Fe(III)-EDDS complex in Fenton-like processes: From the radical formation to the degradation of bisphenol A, Environ. Sci. Technol. 47 (2013) 1952-1959. https://doi.org/10.1021/es304502y.

[83] J. De Laat, H. Gallard, Catalytic Decomposition of Hydrogen Peroxide by Fe(III) in Homogeneous Aqueous Solution: Mechanism and Kinetic Modeling, Environ. Sci. Technol. 33 (1999) 2726-2732. https://doi.org/10.1021/es981171v.

[84] L.S. Nahim Granados, Assessment of Solar-Driven Processes and Ozonation For Disinfection, Decontamination And Reuse of Fresh-Cut Wastewater, Universidad de Almería, 2020.

[85] H.M. Gutiérrez-Zapata, K.L. Rojas, J. Sanabria, J.A. Rengifo-Herrera, 2,4-D abatement from groundwater samples by photo-Fenton processes at circumneutral $\mathrm{pH}$ using naturally iron present. Effect of inorganic ions, Environ. Sci. Pollut. Res. 24 (2017) 6213-6221. https://doi.org/10.1007/s11356-016-7067-5. 
[86] A. Machulek, J.E.F. Moraes, C. Vautier-Giongo, C.A. Silverio, L.C. Friedrich, C.A.O. Nascimento, M.C. Gonzalez, F.H. Quina, Abatement of the Inhibitory Effect of Chloride Anions on the Photo-Fenton Process, Environ. Sci. Technol. 41 (2007) 8459-8463. https://doi.org/10.1021/es071884q.

[87] J. De Laat, T.G. Le, Effects of chloride ions on the iron(III)-catalyzed decomposition of hydrogen peroxide and on the efficiency of the Fenton-like oxidation process, Appl. Catal. B Environ. 66 (2006) 137-146. https://doi.org/10.1016/j.apcatb.2006.03.008.

[88] J. Kiwi, A. Lopez, V. Nadtochenko, Mechanism and kinetics of the OH-radical intervention during Fenton oxidation in the presence of a significant amount of radical scavenger (Cl-), Environ. Sci. Technol. $34 \quad$ (2000) 2162-2168. https://doi.org/10.1021/es991406i.

[89] H. Liu, H. Zhao, X. Quan, Y. Zhang, S. Chen, Formation of Chlorinated Intermediate from Bisphenol A in Surface Saline Water under Simulated Solar Light Irradiation, Environ. Sci. Technol. 43 (2009) 7712-7717. https://doi.org/10.1021/es900811c.

[90] L. Santos-Juanes, A.A. Amat, A. Arques, Strategies to Drive Photo-Fenton Process at Mild Conditions for the Removal of Xenobiotics from Aqueous Systems, Curr. Org. Chem. 21 (2017) 1074-1083. https://doi.org/10.2174/1385272821666170102150337.

[91] BOE, Ley 5/2002, sobre vertidos de aguas residuales industriales a los sistemas públicos de saneamiento, 2002.

[92] I. Carra, S. Malato, M. Jiménez, M.I. Maldonado, J.A. Sánchez Pérez, Microcontaminant removal by solar photo-Fenton at natural $\mathrm{pH}$ run with sequential and continuous iron additions, Chem. Eng. J. $235 \quad$ (2014) 132-140. https://doi.org/10.1016/j.cej.2013.09.029.

[93] A. De Luca, R.F. Dantas, S. Esplugas, Assessment of iron chelates efficiency forphotoFenton at neutral pH, Water Res. $61 \quad$ (2014) 232-242. https://doi.org/10.1016/j.watres.2014.05.033.

[94] J. Gomis, L. Carlos, A.B. Prevot, A.C.S.C. Teixeira, M. Mora, A.M. Amat, R. Vicente, A. Arques, Bio-based substances from urban waste as auxiliaries for solar photo-Fenton treatment under mild conditions: Optimization of operational variables, Catal. Today. 240 (2015) 39-45. https://doi.org/10.1016/j.cattod.2014.03.034. 
[95] S. García-Ballesteros, M. Costante, R. Vicente, M. Mora, A.M. Amat, A. Arques, L. Carlos, F.S.G. Einschlag, Humic-like substances from urban waste as auxiliaries for photo-Fenton treatment: a fluorescence EEM-PARAFAC study, Photochem. Photobiol. Sci. 16 (2017) 38-45. https://doi.org/10.1039/C6PP00236F.

[96] S. García-Ballesteros, J. Grimalt, S. Berto, M. Minella, E. Laurenti, R. Vicente, M.F. López-Pérez, A.M. Amat, A. Bianco Prevot, A. Arques, New Route for Valorization of Oil Mill Wastes: Isolation of Humic-Like Substances to be Employed in Solar-Driven Processes for Pollutants Removal, ACS Omega. 3 (2018) 13073-13080. https://doi.org/10.1021/acsomega.8b01816.

[97] B.I. Kharisov, H. V. Rasika Dias, O. V. Kharissova, V. Manuel Jiménez-Pérez, B. Olvera Pérez, B. Muñoz Flores, Iron-containing nanomaterials: Synthesis, properties, and environmental applications, RSC Adv. 2 (2012) 9325-9358. https://doi.org/10.1039/c2ra20812a.

[98] D. O’Carroll, B. Sleep, M. Krol, H. Boparai, C. Kocur, Nanoscale zero valent iron and bimetallic particles for contaminated site remediation, Adv. Water Resour. 51 (2013) 104-122. https://doi.org/10.1016/j.advwatres.2012.02.005.

[99] Y. Zou, X. Wang, A. Khan, P. Wang, Y. Liu, A. Alsaedi, T. Hayat, X. Wang, Environmental Remediation and Application of Nanoscale Zero-Valent Iron and Its Composites for the Removal of Heavy Metal Ions: A Review, Environ. Sci. Technol. 50 (2016) 7290-7304. https://doi.org/10.1021/acs.est.6b01897.

[100] X. Guan, Y. Sun, H. Qin, J. Li, I.M.C. Lo, D. He, H. Dong, The limitations of applying zero-valent iron technology in contaminants sequestration and the corresponding countermeasures: The development in zero-valent iron technology in the last two decades (1994-2014), Water Res. $75 \quad$ (2015) 224-248. https://doi.org/10.1016/j.watres.2015.02.034.

[101] V.N. Montesinos, N. Quici, E. Beatriz Halac, A.G. Leyva, G. Custo, S. Bengio, G. Zampieri, M.I. Litter, Highly efficient removal of $\mathrm{Cr}(\mathrm{VI})$ from water with nanoparticulated zerovalent iron: Understanding the $\mathrm{Fe}(\mathrm{III})-\mathrm{Cr}(\mathrm{III})$ passive outer layer structure, Chem. Eng. J. 244 (2014) 569-575. https://doi.org/10.1016/j.cej.2014.01.093.

[102] C. Su, R.W. Puls, Arsenate and arsenite removal by zerovalent iron: Effects of phosphate, silicate, carbonate, borate, sulfate, chromate, molybdate, and nitrate, relative 
to chloride, Environ. Sci. Technol. $35 \quad$ (2001) 4562-4568. https://doi.org/10.1021/es010768z.

[103] Y. Liu, T. Phenrat, G. V. Lowry, Effect of TCE concentration and dissolved groundwater solutes on NZVI-promoted TCE dechlorination and $\mathrm{H} 2$ evolution, Environ. Sci. Technol. 41 (2007) 7881-7887. https://doi.org/10.1021/es0711967.

[104] L. Santos-Juanes, S. García-Ballesteros, R.F. Vercher, A.M. Amat, A. Arques, Commercial steel wool used for Zero Valent Iron and as a source of dissolved iron in a combined red-ox process for pentachlorophenol degradation in tap water, Catal. Today. 328 (2019) 252-258. https://doi.org/10.1016/j.cattod.2019.01.007.

[105] F. Liang, J. Fan, Y. Guo, M. Fan, J. Wang, H. Yang, Reduction of nitrite by ultrasounddispersed nanoscale zero-valent iron particles, Ind. Eng. Chem. Res. 47 (2008) 85508554. https://doi.org/10.1021/ie8003946.

[106] T. Raychoudhury, T. Scheytt, Potential of Zerovalent iron nanoparticles for remediation of environmental organic contaminants in water: A review, Water Sci. Technol. 68 (2013) 1425-1439. https://doi.org/10.2166/wst.2013.358.

[107] J.A. Donadelli, L. Carlos, A. Arques, F.S. García Einschlag, Kinetic and mechanistic analysis of azo dyes decolorization by ZVI-assisted Fenton systems: pH-dependent shift in the contributions of reductive and oxidative transformation pathways, Appl. Catal. B Environ. 231 (2018) 51-61. https://doi.org/10.1016/j.apcatb.2018.02.057.

[108] J.A. Donadelli, E. Berardozzi, L. Carlos, F.S. García Einschlag, Continuous treatment of an azo dye based on a combined ZVI/photo-Fenton setup. Process modelling by response surface methodology, J. Water Process Eng. 37 (2020) 101480. https://doi.org/10.1016/j.jwpe.2020.101480.

[109] S.Y. Oh, P.C. Chiu, B.J. Kim, D.K. Cha, Enhancing Fenton oxidation of TNT and RDX through pretreatment with zero-valent iron, Water Res. 37 (2003) 4275-4283. https://doi.org/10.1016/S0043-1354(03)00343-9.

[110] B.C. Jiang, Z.Y. Lu, F.Q. Liu, A.M. Li, J.J. Dai, L. Xu, L.M. Chu, Inhibiting 1,3dinitrobenzene formation in Fenton oxidation of nitrobenzene through a controllable reductive pretreatment with zero-valent iron, Chem. Eng. J. 174 (2011) 258-265. https://doi.org/10.1016/j.cej.2011.09.014. 
[111] B.H. Moon, Y.B. Park, K.H. Park, Fenton oxidation of Orange II by pre-reduction using nanoscale zero-valent iron, Desalination. $268 \quad$ (2011) 249-252. https://doi.org/10.1016/j.desal.2010.10.036.

[112] Stokes Shift, Fluorescence Spectroscopy | Edinburgh Instruments, (n.d.). https://www.edinst.com/blog/what-is-the-stokes-shift/ (accessed June 9, 2021).

[113] D.A. Skoog, J.F. Holler, S.R. Crouch, Principios de análisis instrumental, 6th ed., Cengage Learning, 2009.

[114] A.C. Olivieri, Practical guidelines for reporting results in single- and multi-component analytical calibration: A tutorial, Anal. Chim. Acta. 868 (2015) 10-22. https://doi.org/10.1016/j.aca.2015.01.017.

[115] M. Porcel, Aplicación de técnicas quimiométricas para el desarrollo de nuevos métodos cinético-espectrofotométricos de análisis, Universitat Autònoma de Barcelona, 2001. https://doi.org/10.1007/s13398-014-0173-7.2.

[116] J.N. Miller, J.C. Miller, Estadística y Quimiometría para Química Analítica, Pearson Educación S.A., 2002.

[117] K.R. Murphy, C.A. Stedmon, D. Graeber, R. Bro, Fluorescence spectroscopy and multiway techniques. PARAFAC, Anal. Methods. 5 (2013) 6557. https://doi.org/10.1039/c3ay41160e.

[118] I. Sciscenko, A. Arques, Z. Varga, S. Bouchonnet, O. Monfort, M. Brigante, G. Mailhot, Significant role of iron on the fate and photodegradation of enrofloxacin, Chemosphere. 270 (2021) 129791. https://doi.org/10.1016/j.chemosphere.2021.129791.

[119] I. Sciscenko, H. Thị Mỹ Hắng, C. Escudero-Oñate, I. Oller, A. Arques, Fluorescence Spectroscopy and Chemometrics: A Simple and Easy Way for the Monitoring of Fluoroquinolone Mixture Degradation, ACS Omega. 6 (2021) 4663-4671. https://doi.org/10.1021/acsomega.0c05370.

[120] P.G. Coble, Characterization of marine and terrestrial DOM in seawater using excitation-emission matrix spectroscopy, Mar. Chem. 51 (1996) 325-346. https://doi.org/10.1016/0304-4203(95)00062-3.

[121] L. Li, Y. Wang, W. Zhang, S. Yu, X. Wang, N. Gao, New advances in fluorescence excitation-emission matrix spectroscopy for the characterization of dissolved organic 
matter in drinking water treatment: A review, Chem. Eng. J. 381 (2020) 122676. https://doi.org/10.1016/j.cej.2019.122676.

[122] P. Micó, S. García-Ballesteros, M. Mora, R. Vicente, A.M. Amat, A. Arques, EEMlab: A graphical user-friendly interface for fluorimetry experiments based on the drEEM toolbox, Chemom. Intell. Lab. Syst. $188 \quad$ (2019) 6-13. https://doi.org/10.1016/j.chemolab.2019.03.001.

[123] S.J. Mazivila, S.A. Bortolato, A.C. Olivieri, MVC3_GUI: A MATLAB graphical user interface for third-order multivariate calibration. An upgrade including new multi-way models, Chemom. Intell. Lab. Syst. $173 \quad$ (2018) 21-29. https://doi.org/10.1016/j.chemolab.2017.12.012.

[124] L. Yang, J. Hur, W. Zhuang, Occurrence and behaviors of fluorescence EEMPARAFAC components in drinking water and wastewater treatment systems and their applications: A review, Environ. Sci. Pollut. Res. 22 (2015) 6500-6510. https://doi.org/10.1007/s11356-015-4214-3.

[125] W. Chen, P. Westerhoff, J.A. Leenheer, K. Booksh, Fluorescence Excitation-Emission Matrix Regional Integration to Quantify Spectra for Dissolved Organic Matter, Environ. Sci. Technol. 37 (2003) 5701-5710. https://doi.org/10.1021/es034354c.

[126] R.K. Henderson, A. Baker, K.R. Murphy, A. Hambly, R.M. Stuetz, S.J. Khan, Fluorescence as a potential monitoring tool for recycled water systems: A review, Water Res. 43 (2009) 863-881. https://doi.org/10.1016/j.watres.2008.11.027.

[127] J.P.R. Sorensen, A. Baker, S.A. Cumberland, D.J. Lapworth, A.M. MacDonald, S. Pedley, R.G. Taylor, J.S.T. Ward, Real-time detection of faecally contaminated drinking water with tryptophan-like fluorescence: defining threshold values, Sci. Total Environ. 622-623 (2018) 1250-1257. https://doi.org/10.1016/j.scitotenv.2017.11.162.

[128] M. Sgroi, P. Roccaro, G. V. Korshin, V. Greco, S. Sciuto, T. Anumol, S.A. Snyder, F.G.A. Vagliasindi, Use of fluorescence EEM to monitor the removal of emerging contaminants in full scale wastewater treatment plants, J. Hazard. Mater. 323 (2017) 367-376. https://doi.org/10.1016/j.jhazmat.2016.05.035.

[129] A.D. Pifer, S.L. Cousins, J.L. Fairey, Assessing UV- and fluorescence-based metrics as disinfection byproduct precursor surrogate parameters in a water body influenced by a 
heavy rainfall event, J. Water Supply Res. Technol. - AQUA. 63 (2014) 200-211. https://doi.org/10.2166/aqua.2013.122.

[130] R.G.M. Spencer, L. Bolton, A. Baker, Freeze/thaw and pH effects on freshwater dissolved organic matter fluorescence and absorbance properties from a number of UK locations, Water $\quad$ Res. $41 \quad$ (2007) 2941-2950. https://doi.org/10.1016/j.watres.2007.04.012.

[131] J. Świetlik, E. Sikorska, Application of fluorescence spectroscopy in the studies of natural organic matter fractions reactivity with chlorine dioxide and ozone, Water Res. 38 (2004) 3791-3799. https://doi.org/10.1016/j.watres.2004.06.010.

[132] Q.V. Ly, H.C. Kim, J. Hur, Tracking fluorescent dissolved organic matter in hybrid ultrafiltration systems with TiO2/UV oxidation via EEM-PARAFAC, J. Memb. Sci. 549 (2018) 275-282. https://doi.org/10.1016/j.memsci.2017.12.020.

[133] Y.Z. Yang, N.M. Peleato, R.L. Legge, R.C. Andrews, Towards real-time detection of wastewater in surface waters using fluorescence spectroscopy, J. Environ. Sci. (China). 86 (2019) 195-202. https://doi.org/10.1016/j.jes.2019.06.002.

[134] C.W. Cuss, S.M. McConnell, C. Guéguen, Combining parallel factor analysis and machine learning for the classification of dissolved organic matter according to source using fluorescence signatures, Chemosphere. $155 \quad$ (2016) 283-291. https://doi.org/10.1016/j.chemosphere.2016.04.061.

[135] M.D. Carabajal, J.A. Arancibia, G.M. Escandar, Excitation-emission fluorescencekinetic data obtained by Fenton degradation. Determination of heavy-polycyclic aromatic hydrocarbons by four-way parallel factor analysis, Talanta. 165 (2017) 52-63. https://doi.org/10.1016/j.talanta.2016.12.030.

[136] S. García-Ballesteros, M. Mora, R. Vicente, R.F. Vercher, C. Sabater, M.A. Castillo, A.M. Amat, A. Arques, A new methodology to assess the performance of AOPs in complex samples: Application to the degradation of phenolic compounds by $\mathrm{O} 3$ and O3/UV-A-Vis, Chemosphere. $222 \quad$ (2019) 114-123. https://doi.org/10.1016/j.chemosphere.2019.01.015.

[137] I. Sciscenko, S. Garcia-Ballesteros, C. Sabater, M.A. Castillo, C. Escudero-Oñate, I. Oller, A. Arques, Monitoring photolysis and (solar photo)-Fenton of enrofloxacin by a 
methodology involving EEM-PARAFAC and bioassays: Role of $\mathrm{pH}$ and water matrix,

$\begin{array}{lllll}\text { Sci. Total } & \text { Environ. } & 719 & \text { (2020) }\end{array}$

https://doi.org/10.1016/j.scitotenv.2020.137331.

[138] D. Palma, E. Parlanti, M. Sourzac, O. Voldoire, A. Beauger, M. Sleiman, C. Richard, Fluorescence analysis allows to predict the oxidative capacity of humic quinones in dissolved organic matter: implication for pollutant degradation, Environ. Chem. Lett. (2020). https://doi.org/10.1007/s10311-020-01137-z.

[139] S. Garcia-Ballesteros, Desarrollo de nuevas estrategias basadas en la integración de procesos fotoquímicos solares con otras técnicas avanzadas para el tratamiento de aguas residuales complejas, Universitat Politècnica de València, 2017. https://doi.org/10.4995/Thesis/10251/95602.

[140] S. García-Ballesteros, M. Mora, R. Vicente, C. Sabater, M.A. Castillo, A. Arques, A.M. Amat, Gaining further insight into photo-Fenton treatment of phenolic compounds commonly found in food processing industry, Chem. Eng. J. 288 (2016) 126-136. https://doi.org/10.1016/j.cej.2015.11.031.

[141] A. Bernabeu, R.F. Vercher, L. Santos-Juanes, P.J. Simón, C. Lardín, M.A. Martínez, J.A. Vicente, R. González, C. Llosá, A. Arques, A.M. Amat, Solar photocatalysis as a tertiary treatment to remove emerging pollutants from wastewater treatment plant effluents, $\quad$ Catal. $\quad$ Today. $\quad 161 \quad$ (2011) 235-240. https://doi.org/10.1016/j.cattod.2010.09.025.

[142] I. Oller, Depuración de aguas contaminadas con tóxicos persistentes mediante combinación de fotocatálisis solar y oxidación biológica, Universidad de Almería, 2008.

[143] E. Viollier, P.W. Inglett, K. Hunter, A.N. Roychoudhury, P. Van Cappellen, The Ferrozine method revisted, Appl. Geochemistry. $15 \quad$ (2000) 785-790. https://doi.org/10.1016/S0883-2927(99)00097-9.

[144] R.F.P. Nogueira, M.C. Oliveira, W.C. Paterlini, Simple and fast spectrophotometric determination of $\mathrm{H} 2 \mathrm{O} 2$ in photo-Fenton reactions using metavanadate, Talanta. 66 (2005) 86-91. https://doi.org/10.1016/j.talanta.2004.10.001.

[145] D.W. O'Sullivan, M. Tyree, The kinetics of complex formation between Ti(IV) and hydrogen peroxide, Int. J. Chem. Kinet. 39 (2007) 457-461. 
https://doi.org/10.1002/kin.20259.

[146] A.J. Lawaetz, C.A. Stedmon, Fluorescence intensity calibration using the Raman scatter peak of water, Appl. Spectrosc. $63 \quad$ (2009) 936-940. https://doi.org/10.1366/000370209788964548.

[147] R. Bro, H.A.L. Kiers, A new efficient method for determining the number of components in PARAFAC models, J. Chemom. 17 (2003) 274-286. https://doi.org/10.1002/cem.801.

[148] K.R. Murphy, C.A. Stedmon, D. Graeber, R. Bro, Decomposition routines for Excitation Emission Matrices Originally published as an Appendix to :, Anal. Methods. (2013) 129. https://doi.org/10.1039/c3ay41160e.drEEM.

[149] D.A. Skoog, D.M. West, Principles of Instrumental Analysis, 2nd ed., 1980. http://repositorio.unan.edu.ni/2986/1/5624.pdf.

[150] S. Banerjee, S. Mazumdar, Electrospray Ionization Mass Spectrometry: A Technique to Access the Information beyond the Molecular Weight of the Analyte, Int. J. Anal. Chem. 2012 (2012) 1-40. https://doi.org/10.1155/2012/282574.

[151] I. Turel, The interactions of metal ions with quinolone antibacterial agents, Coord. Chem. Rev. 232 (2002) 27-47. https://doi.org/10.1016/S0010-8545(02)00027-9.

[152] E.K. Efthimiadou, A. Karaliota, G. Psomas, Mononuclear metal complexes of the second-generation quinolone antibacterial agent enrofloxacin: Synthesis, structure, antibacterial activity and interaction with DNA, Polyhedron. 27 (2008) 1729-1738. https://doi.org/10.1016/j.poly.2008.02.006.

[153] S. Ramotowska, M. Wysocka, J. Brzeski, A. Chylewska, M. Makowski, A comprehensive approach to the analysis of antibiotic-metal complexes, TrAC - Trends Anal. Chem. 123 (2020). https://doi.org/10.1016/j.trac.2019.115771.

[154] M.C. Cuquerella, A. Belvedere, A. Catalfo, M.A. Miranda, J.C. Scaiano, G. de Guidi, Effects of bio-compatible metal ions on rufloxacin photochemistry, photophysics and photosensitization: Copper(II), J. Photochem. Photobiol. B Biol. 101 (2010) 295-303. https://doi.org/10.1016/j.jphotobiol.2010.07.015.

[155] S. Wang, Z. Wang, C. Hao, W.J.G.M. Peijnenburg, DFT/TDDFT insights into effects of dissociation and metal complexation on photochemical behavior of enrofloxacin in 
water, Environ. Sci. Pollut. Res. $25 \quad$ (2018) 30609-30616. https://doi.org/10.1007/s11356-018-3032-9.

[156] C. Le, J. Liang, J. Wu, P. Li, X. Wang, N. Zhu, P. Wu, B. Yang, Effective degradation of para-chloronitrobenzene through a sequential treatment using zero-valent iron reduction and Fenton oxidation, Water Sci. Technol. 64 (2011) 2126-2131. https://doi.org/10.2166/wst.2011.803.

[157] X. Wei, J. Chen, Q. Xie, S. Zhang, Y. Li, Y. Zhang, H. Xie, Photochemical behavior of antibiotics impacted by complexation effects of concomitant metals: A case for ciprofloxacin and $\mathrm{Cu}(\mathrm{II})$, Environ. Sci. Process. Impacts. 17 (2015) 1220-1227. https://doi.org/10.1039/c5em00204d.

[158] U. Hubicka, J. Krzek, B. Zuromska, M. Walczak, M. Zylewski, D. Pawłowski, Determination of photostability and photodegradation products of moxifloxacin in the presence of metal ions in solutions and solid phase. Kinetics and identification of photoproducts, Photochem. Photobiol. Sci. $11 \quad$ (2012) 351-357. https://doi.org/10.1039/c1pp05259d.

[159] Y. Gou, P. Chen, L. Yang, S. Li, L. Peng, S. Song, Y. Xu, Degradation of fluoroquinolones in homogeneous and heterogeneous photo-Fenton processes: A review, Chemosphere. (2020) 129481. https://doi.org/10.1016/j.chemosphere.2020.129481.

[160] W. Qiu, M. Zheng, J. Sun, Y. Tian, M. Fang, Y. Zheng, T. Zhang, C. Zheng, Photolysis of enrofloxacin, pefloxacin and sulfaquinoxaline in aqueous solution by UV/H2O2, $\mathrm{UV} / \mathrm{Fe}(\mathrm{II})$, and $\mathrm{UV} / \mathrm{H} 2 \mathrm{O} 2 / \mathrm{Fe}(\mathrm{II})$ and the toxicity of the final reaction solutions on zebrafish embryos, Sci. Total Environ. 651 (2019) 1457-1468. https://doi.org/10.1016/j.scitotenv.2018.09.315.

[161] W. Huang, A. Bianco, M. Brigante, G. Mailhot, UVA-UVB activation of hydrogen peroxide and persulfate for advanced oxidation processes: Efficiency, mechanism and effect of various water constituents, J. Hazard. Mater. 347 (2018) 279-287. https://doi.org/10.1016/j.jhazmat.2018.01.006.

[162] Y. Tao, M. Brigante, H. Zhang, G. Mailhot, Phenanthrene degradation using Fe(III)EDDS photoactivation under simulated solar light: A model for soil washing effluent treatment,

Chemosphere.

236

(2019)

124366. 
https://doi.org/10.1016/j.chemosphere.2019.124366.

[163] J.S. Renny, L.L. Tomasevich, E.H. Tallmadge, D.B. Collum, Method of Continuous Variations: Applications of Job Plots to the Study of Molecular Associations in Organometallic Chemistry, Angew. Chemie Int. Ed. 52 (2013) 11998-12013. https://doi.org/10.1002/anie.201304157.

[164] W.R. Haag, J. Hoigné, E. Gassman, A.M. Braun, Singlet oxygen in surface waters - Part I: Furfuryl alcohol as a trapping agent, Chemosphere. 13 (1984) 631-640. https://doi.org/10.1016/0045-6535(84)90199-1.

[165] A.D. Bokare, W. Choi, Singlet-Oxygen Generation in Alkaline Periodate Solution, $\begin{array}{lllll}\text { Environ. } & \text { Sci. } & \text { Technol. } & 49 & \text { (2015) }\end{array}$ https://doi.org/10.1021/acs.est.5b04119.

[166] D.E. Latch, B.L. Stender, J.L. Packer, W.A. Arnold, K. McNeill, Photochemical fate of pharmaceuticals in the environment: Cimetidine and ranitidine, Environ. Sci. Technol. 37 (2003) 3342-3350. https://doi.org/10.1021/es0340782.

[167] W.R. Haag, T. Mill, RATE CONSTANTS FOR INTERACTION OF 1O21 $\Delta$ g) WITH AZIDE ION IN WATER, Photochem. Photobiol. 45 (1987) 317-321. https://doi.org/10.1111/j.1751-1097.1987.tb05381.x.

[168] E. Appiani, R. Ossola, D.E. Latch, P.R. Erickson, K. McNeill, Aqueous singlet oxygen reaction kinetics of furfuryl alcohol: Effect of temperature, $\mathrm{pH}$, and salt content, Environ. Sci. Process. $\quad$ Impacts. $19 \quad$ (2017) 507-516. https://doi.org/10.1039/c6em00646a.

[169] B. Urbaniak, Z.J. Kokot, Analysis of the factors that significantly influence the stability of fluoroquinolone-metal complexes, Anal. Chim. Acta. 647 (2009) 54-59. https://doi.org/10.1016/j.aca.2009.05.039.

[170] M. Bucheli-Witschel, T. Egli, Environmental fate and microbial degradation of aminopolycarboxylic acids, FEMS Microbiol. Rev. 25 (2001) 69-106. https://doi.org/10.1016/S0168-6445(00)00055-3.

[171] Y. Chen, A. Wang, Y. Zhang, R. Bao, X. Tian, J. Li, Electro-Fenton degradation of antibiotic ciprofloxacin (CIP): Formation of Fe3+-CIP chelate and its effect on catalytic behavior of $\mathrm{Fe} 2+/ \mathrm{Fe} 3+$ and CIP mineralization, Electrochim. Acta. 256 (2017) 185-195. 
https://doi.org/10.1016/j.electacta.2017.09.173.

[172] S. Miralles-Cuevas, I. Oller, J.A.S. Pérez, S. Malato, Removal of pharmaceuticals from MWTP effluent by nanofiltration and solar photo-Fenton using two different iron complexes at neutral pH, Water Res. 64 (2014) 23-31. https://doi.org/10.1016/j.watres.2014.06.032.

[173] F. Martínez, M.J. López-Muñoz, J. Aguado, J.A. Melero, J. Arsuaga, A. Sotto, R. Molina, Y. Segura, M.I. Pariente, A. Revilla, L. Cerro, G. Carenas, Coupling membrane separation and photocatalytic oxidation processes for the degradation of pharmaceutical pollutants, Water $\quad$ Res. $47 \quad$ (2013) 5647-5658. https://doi.org/10.1016/j.watres.2013.06.045.

[174] L. Ge, C. Halsall, C.E. Chen, P. Zhang, Q. Dong, Z. Yao, Exploring the aquatic photodegradation of two ionisable fluoroquinolone antibiotics - Gatifloxacin and balofloxacin: Degradation kinetics, photobyproducts and risk to the aquatic environment, Sci. Total Environ. $633 \quad$ (2018) 1192-1197. https://doi.org/10.1016/j.scitotenv.2018.03.279.

[175] X.Z. Niu, E.G. Moore, J.P. Croué, Excited Triplet State Interactions of Fluoroquinolone Norfloxacin with Natural Organic Matter: A Laser Spectroscopy Study, Environ. Sci. Technol. 52 (2018) 10426-10432. https://doi.org/10.1021/acs.est.8b02835.

[176] M. Sturini, A. Speltini, F. Maraschi, A. Profumo, L. Pretali, E. Fasani, A. Albini, Photochemical degradation of marbofloxacin and enrofloxacin in natural waters, Environ. Sci. Technol. 44 (2010) 4564-4569. https://doi.org/10.1021/es100278n.

[177] A. Bianco, M. Passananti, H. Perroux, G. Voyard, C. Mouchel-Vallon, N. Chaumerliac, G. Mailhot, L. Deguillaume, M. Brigante, A better understanding of hydroxyl radical photochemical sources in cloud waters collected at the puy de Dôme station Experimental versus modelled formation rates, Atmos. Chem. Phys. 15 (2015) 91919202. https://doi.org/10.5194/acp-15-9191-2015.

[178] L. Ge, J. Chen, W. Xiaoxuan, S. Zhang, X. Qiao, C. Xiyun And, X. Qing, Aquatic photochemistry of fluoroquinolone antibiotics: kinetics, pathways, and multivariate effects of main water constituents, Environ. Sci. Technol. 44 (2010) 2400-2405. https://doi.org/10.1021/es902852v. 
[179] K.H. Wammer, A.R. Korte, R.A. Lundeen, J.E. Sundberg, K. McNeill, W.A. Arnold, Direct photochemistry of three fluoroquinolone antibacterials: Norfloxacin, ofloxacin, and enrofloxacin, Water Res. $47 \quad$ (2013) 439-448. https://doi.org/10.1016/j.watres.2012.10.025.

[180] T. An, H. Yang, G. Li, W. Song, W.J. Cooper, X. Nie, Kinetics and mechanism of advanced oxidation processes (AOPs) in degradation of ciprofloxacin in water, Appl. Catal. B Environ. 94 (2010) 288-294. https://doi.org/10.1016/j.apcatb.2009.12.002.

[181] M. Sturini, A. Speltini, F. Maraschi, A. Profumo, L. Pretali, E.A. Irastorza, E. Fasani, A. Albini, Photolytic and photocatalytic degradation of fluoroquinolones in untreated river water under natural sunlight, Appl. Catal. B Environ. 119-120 (2012) 32-39. https://doi.org/10.1016/j.apcatb.2012.02.008.

[182] J. Porras, C. Bedoya, J. Silva-Agredo, A. Santamaría, J.J. Fernández, R.A. TorresPalma, Role of humic substances in the degradation pathways and residual antibacterial activity during the photodecomposition of the antibiotic ciprofloxacin in water, Water Res. 94 (2016) 1-9. https://doi.org/10.1016/j.watres.2016.02.024.

[183] P. Villegas-Guzman, S. Oppenheimer-Barrot, J. Silva-Agredo, R.A. Torres-Palma, Comparative Evaluation of Photo-Chemical AOPs for Ciprofoxacin Degradation: Elimination in Natural Waters and Analysis of pH Effect, Primary Degradation ByProducts, and the Relationship with the Antibiotic Activity, Water. Air. Soil Pollut. 228 (2017) 209-224. https://doi.org/10.1007/s11270-017-3388-3.

[184] T. Haddad, K. Kümmerer, Characterization of photo-transformation products of the antibiotic drug Ciprofloxacin with liquid chromatography-tandem mass spectrometry in combination with accurate mass determination using an LTQ-Orbitrap, Chemosphere. 115 (2014) 40-46. https://doi.org/10.1016/j.chemosphere.2014.02.013.

[185] M. Passananti, V. Vinatier, A.M. Delort, G. Mailhot, M. Brigante, Siderophores in cloud waters and potential impact on atmospheric chemistry: Photoreactivity of iron complexes under sun-simulated conditions, Environ. Sci. Technol. 50 (2016) 93249332. https://doi.org/10.1021/acs.est.6b02338.

[186] O. Abida, G. Mailhot, M. Litter, M. Bolte, Impact of iron-complex (Fe(III)-NTA) on photoinduced degradation of 4-chlorophenol in aqueous solution, Photochem. Photobiol. Sci. 5 (2006) 395-402. https://doi.org/10.1039/b518211e. 
[187] I. Sciscenko, S. Mestre, J. Climent, F. Valero, C. Escudero-Oñate, I. Oller, A. Arques, Magnetic Photocatalyst for Wastewater Tertiary Treatment at Pilot Plant Scale: Disinfection and Enrofloxacin Abatement, Water. $13 \quad$ (2021) 329. https://doi.org/10.3390/w13030329.

[188] N. Daneshvar, M.A. Behnajady, M.K.A. Mohammadi, M.S.S. Dorraji, UV/H2O2 treatment of Rhodamine B in aqueous solution: Influence of operational parameters and kinetic modeling, Desalination. $230 \quad$ (2008) 16-26. https://doi.org/10.1016/j.desal.2007.11.012.

[189] S.K. Kansal, M. Singh, D. Sud, Studies on photodegradation of two commercial dyes in aqueous phase using different photocatalysts, J. Hazard. Mater. 141 (2007) 581-590. https://doi.org/10.1016/j.jhazmat.2006.07.035.

[190] J. Zhao, T. Wu, K. Wu, K. Oikawa, H. Hidaka, N. Serpone, Photoassisted degradation of dye pollutants. 3. Degradation of the cationic dye rhodamine B in aqueous anionic surfactant/TiO2 dispersions under visible light irradiation: Evidence for the need of substrate adsorption on TiO2 particles, Environ. Sci. Technol. 32 (1998) 2394-2400. https://doi.org/10.1021/es9707926.

[191] J. Gomis, M.G. Gonçalves, R.F. Vercher, C. Sabater, M.A. Castillo, A.B. Prevot, A.M. Amat, A. Arques, Determination of photostability, biocompatibility and efficiency as photo-Fenton auxiliaries of three different types of soluble bio-based substances (SBO), Catal. Today. 252 (2015) 177-183. https://doi.org/10.1016/j.cattod.2014.10.015.

[192] R.S. Ayers, D.W. Westcot, Water quality for agriculture, ISBN 92-5-102263-1. (n.d.). http://www.fao.org/3/t0234e/t0234e00.htm (accessed May 22, 2020).

[193] L. Wang, J. Ali, Z. Wang, N.A. Oladoja, R. Cheng, C. Zhang, G. Mailhot, G. Pan, Oxygen nanobubbles enhanced photodegradation of oxytetracycline under visible light: Synergistic effect and mechanism, Chem. Eng. J. 388 (2020) 124227. https://doi.org/10.1016/j.cej.2020.124227.

[194] W.L. Kostedt IV, J. Drwiega, D.W. Mazyck, S.W. Lee, W. Sigmund, C.Y. Wu, P. Chadik, Magnetically agitated photocatalytic reactor for photocatalytic oxidation of aqueous phase organic pollutants, Environ. Sci. Technol. 39 (2005) 8052-8056. https://doi.org/10.1021/es0508121. 
[195] J.J. Pignatello, D. Liu, P. Huston, Evidence for an additional oxidant in the photoassisted Fenton reaction, Environ. Sci. Technol. 33 (1999) 1832-1839. https://doi.org/10.1021/es980969b.

[196] S. Liu, G. Dong, H. Zhao, M. Chen, W. Quan, B. Qu, Occurrence and risk assessment of fluoroquinolones and tetracyclines in cultured fish from a coastal region of northern China, Environ. Sci. Pollut. Res. 25 (2018) 8035-8043. https://doi.org/10.1007/s11356017-1177-6.

[197] R. Karoui, J. De Baerdemaeker, A review of the analytical methods coupled with chemometric tools for the determination of the quality and identity of dairy products, Food Chem. 102 (2007) 621-640. https://doi.org/10.1016/j.foodchem.2006.05.042.

[198] J.C.L. Alves, R.J. Poppi, Simultaneous determination of hydrocarbon renewable diesel, biodiesel and petroleum diesel contents in diesel fuel blends using near infrared (NIR) spectroscopy and chemometrics, Analyst. $138 \quad$ (2013) 6477-6487. https://doi.org/10.1039/c3an00883e.

[199] F. Boughattas, B. Le Fur, R. Karoui, Non-Targeted Identification of Brine Covered Canned Tuna Species Using Front-Face Fluorescence Spectroscopy Combined with Chemometric Tools, Food Anal. Methods. $12 \quad$ (2019) 2823-2834. https://doi.org/10.1007/s12161-019-01638-w.

[200] J. Trawiński, R. Skibiński, Photolytic and photocatalytic transformation of an antipsychotic drug asenapine: Comparison of kinetics, identification of transformation products, and in silico estimation of their properties, Ecotoxicol. Environ. Saf. 162 (2018) 272-286. https://doi.org/10.1016/j.ecoenv.2018.07.010.

[201] A.M. De la Peña, A. Mansilla Espinosa, D. Gómez González, A.C. Olivieri, H.C. Goicoechea, Interference-Free Analysis Using Three-Way Fluorescence Data and the Parallel Factor Model . Determination of Fluoroquinolone Antibiotics in, Anal. Chem. 75 (2003) 2640-2646. https://doi.org/10.1021/ac026360h.

[202] M. Vosough, S.N. Eshlaghi, R. Zadmard, On the performance of multiway methods for simultaneous quantification of two fluoroquinolones in urine samples by fluorescence spectroscopy and second-order calibration strategies, Spectrochim. Acta - Part A Mol. Biomol. Spectrosc. 136 (2015) 618-624. https://doi.org/10.1016/j.saa.2014.09.075. 
[203] Y. Ni, S. Du, S. Kokot, Molecular spectroscopy and chemometrics: An analytical study of synergistic effects of drugs - Interaction between fluoroquinolones and DNA, Analyst. 134 (2009) 1840-1847. https://doi.org/10.1039/b904018h.

[204] J. Gomis, A. Bianco Prevot, E. Montoneri, M.C. González, A.M. Amat, D.O. Mártire, A. Arques, L. Carlos, Waste sourced bio-based substances for solar-driven wastewater remediation: Photodegradation of emerging pollutants, Chem. Eng. J. 235 (2014) 236243. https://doi.org/10.1016/j.cej.2013.09.009.

[205] M. Lizondo, M. Pons, M. Gallardo, J. Estelrich, Physicochemical properties of enrofloxacin, J. Pharm. Biomed. Anal. $15 \quad$ (1997) 1845-1849. https://doi.org/10.1016/S0731-7085(96)02033-X.

[206] R. Bro, PARAFAC. Tutorial and applications, Chemom. Intell. Lab. Syst. 38 (1997) 149-171. https://doi.org/10.1016/S0169-7439(97)00032-4.

[207] A.S. Giri, A.K. Golder, Ciprofloxacin degradation in photo-Fenton and photo-catalytic processes: Degradation mechanisms and iron chelation, J. Environ. Sci. (China). 80 (2019) 82-92. https://doi.org/10.1016/j.jes.2018.09.016.

[208] J. Soler, A. García-Ripoll, N. Hayek, P. Miró, R. Vicente, A. Arques, A.M. Amat, Effect of inorganic ions on the solar detoxification of water polluted with pesticides, Water Res. 43 (2009) 4441-4450. https://doi.org/doi:10.1016/j.watres.2009.07.011.

[209] L. Ge, G. Na, S. Zhang, K. Li, P. Zhang, H. Ren, Z. Yao, New insights into the aquatic photochemistry of fluoroquinolone antibiotics: Direct photodegradation, hydroxylradical oxidation, and antibacterial activity changes, Sci. Total Environ. 527-528 (2015) 12-17. https://doi.org/10.1016/j.scitotenv.2015.04.099.

[210] J. Aufartová, I. Brabcová, M.E. Torres-Padrón, P. Solich, Z. Sosa-Ferrera, J.J. SantanaRodríguez, Determination of fluoroquinolones in fishes using microwave-assisted extraction combined with ultra-high performance liquid chromatography and fluorescence detection, J. Food Compos. Anal. 56 (2017) 140-146. https://doi.org/10.1016/j.jfca.2016.12.012.

[211] L. Santos-Juanes, F.S. García Einschlag, A.M. Amat, A. Arques, Combining ZVI reduction with photo-Fenton process for the removal of persistent pollutants, Chem. Eng. J. 310 (2017) 484-490. https://doi.org/10.1016/j.cej.2016.04.114. 
[212] Y.J. Jung, W.G. Kim, Y. Yoon, J.W. Kang, Y.M. Hong, H.W. Kim, Removal of amoxicillin by UV and UV/H2O2 processes, Sci. Total Environ. 420 (2012) 160-167. https://doi.org/10.1016/j.scitotenv.2011.12.011.

[213] H.R. Park, T.H. Kim, K.M. Bark, Physicochemical properties of quinolone antibiotics in various environments, Eur. J. Med. Chem. 37 (2002) 443-460. https://doi.org/10.1016/S0223-5234(02)01361-2.

[214] H.R. Park, C.H. Oh, H.C. Lee, J.G. Choi, B.I. Jung, K.M. Bark, Quenching of ofloxacin and flumequine fluorescence by divalent transition metal cations, Bull. Korean Chem. Soc. 27 (2006) 2002-2010. https://doi.org/10.5012/bkcs.2006.27.12.2002.

[215] D.L. Ross, C.M. Riley, Physicochemical properties of the fluoroquinolone antimicrobials. III. Complexation of lomefloxacin with various metal ions and the effect of metal ion complexation on aqueous solubility, Int. J. Pharm. 87 (1992) 203-213. https://doi.org/10.1016/0378-5173(92)90244-V.

[216] A. Gümrükçüoğlu, Y. Topaloğlu, A. Mermer, N. Demirbaş, A. Demirbaş, M. Ocak, Ü. Ocak, 4-Quinolone-Carboxamide and Carbothioamide Compounds as Fluorescent Sensors. New Fluorimetric Methods for $\mathrm{Cu} 2+$ and Fe3+ Determination in Tap Water and Soil, J. Fluoresc. 29 (2019) 921-931. https://doi.org/10.1007/s10895-019-02404-1.

[217] L. Aristilde, A. Melis, G. Sposito, Inhibition of photosynthesis by a fluoroquinolone antibiotic, Environ. Sci. Technol. $44 \quad$ (2010) 1444-1450. https://doi.org/10.1021/es902665n.

[218] I. Michael, E. Hapeshi, J. Aceña, S. Perez, M. Petrović, A. Zapata, D. Barceló, S. Malato, D. Fatta-Kassinos, Light-induced catalytic transformation of ofloxacin by solar Fenton in various water matrices at a pilot plant: Mineralization and characterization of major intermediate products, Sci. Total Environ. 461-462 (2013) 39-48. https://doi.org/10.1016/j.scitotenv.2013.04.054.

[219] X.Z. Niu, F. Busetti, M. Langsa, J.P. Croué, Roles of singlet oxygen and dissolved organic matter in self-sensitized photo-oxidation of antibiotic norfloxacin under sunlight irradiation, Water $\quad$ Res. $106 \quad$ (2016) 214-222. https://doi.org/10.1016/j.watres.2016.10.002.

[220] K.R. Murphy, A. Hambly, S. Singh, R.K. Henderson, A. Baker, R. Stuetz, S.J. Khan, 
Organic matter fluorescence in municipal water recycling schemes: Toward a unified PARAFAC model, Environ. Sci. Technol. $45 \quad$ (2011) 2909-2916. https://doi.org/10.1021/es103015e.

[221] B.G. Fox, R.M.S. Thorn, A.M. Anesio, D.M. Reynolds, The in situ bacterial production of fluorescent organic matter; an investigation at a species level, Water Res. 125 (2017) 350-359. https://doi.org/10.1016/j.watres.2017.08.040.

[222] S. Nowicki, D.J. Lapworth, J.S.T. Ward, P. Thomson, K. Charles, Tryptophan-like fluorescence as a measure of microbial contamination risk in groundwater, Sci. Total Environ. 646 (2019) 782-791. https://doi.org/10.1016/j.scitotenv.2018.07.274.

[223] L. Yang, H.S. Shin, J. Hur, Estimating the concentration and biodegradability of organic matter in 22 wastewater treatment plants using fluorescence excitation emission matrices and parallel factor analysis, Sensors (Switzerland). 14 (2014) 1771-1786. https://doi.org/10.3390/s140101771.

[224] Y. Shutova, A. Baker, J. Bridgeman, R.K. Henderson, Spectroscopic characterisation of dissolved organic matter changes in drinking water treatment: From PARAFAC analysis to online monitoring wavelengths, Water Res. 54 (2014) 159-169. https://doi.org/10.1016/j.watres.2014.01.053.

[225] Z. Chen, Y. Liu, W. Wei, B.J. Ni, Recent advances in electrocatalysts for halogenated organic pollutant degradation, Environ. Sci. Nano. 6 (2019) 2332-2366. https://doi.org/10.1039/c9en00411d.

[226] C. Zhang, F. Li, R. Wen, H. Zhang, P. Elumalai, Q. Zheng, H. Chen, Y. Yang, M. Huang, G. Ying, Heterogeneous electro-Fenton using three-dimension NZVI-BC electrodes for degradation of neonicotinoid wastewater, Water Res. 182 (2020) 115975. https://doi.org/10.1016/j.watres.2020.115975.

[227] K.-S. Ju, R.E. Parales, Nitroaromatic Compounds, from Synthesis to Biodegradation, Microbiol. Mol. Biol. Rev. 74 (2010) 250-272. https://doi.org/10.1128/mmbr.00006-10.

[228] P. Fan, X. Zhang, H. Deng, X. Guan, Enhanced reduction of p-nitrophenol by zerovalent iron modified with carbon quantum dots, Appl. Catal. B Environ. 285 (2021) 119829. https://doi.org/10.1016/j.apcatb.2020.119829.

[229] J. Tiwari, P. Tarale, S. Sivanesan, A. Bafana, Environmental persistence, hazard, and 
mitigation challenges of nitroaromatic compounds, Environ. Sci. Pollut. Res. 26 (2019) 28650-28667. https://doi.org/10.1007/s11356-019-06043-8.

[230] N. Fujioka, M. Suzuki, S. Kurosu, Y. Kawase, Linkage of iron elution and dissolved oxygen consumption with removal of organic pollutants by nanoscale zero-valent iron: Effects of $\mathrm{pH}$ on iron dissolution and formation of iron oxide/hydroxide layer, $\begin{array}{lll}\text { Chemosphere. } & 144 & \text { (2016) }\end{array}$ https://doi.org/10.1016/j.chemosphere.2015.10.064.

[231] D. Ribas, M. Černík, J.A. Benito, J. Filip, V. Marti, Activation process of air stable nanoscale zero-valent iron particles, Chem. Eng. J. 320 (2017) 290-299. https://doi.org/10.1016/j.cej.2017.03.056.

[232] C.A. Gorski, M.M. Scherer, Influence of magnetite stoichiometry on FeII uptake and nitrobenzene reduction, Environ. Sci. Technol. 43 (2009) 3675-3680. https://doi.org/10.1021/es803613a.

[233] J. Klausen, S.P. Tröber, S.B. Haderlein, R.P. Schwarzenbach, Reduction of Substituted Nitrobenzenes by Fe (II) in Aqueous Mineral Suspensions, Environ. Sci. Technol. 29 (1995) 2396-2404. https://doi.org/10.1021/es00009a036.

[234] P.A. Cárdenas-Hernández, K.A. Anderson, J. Murillo-Gelvez, D.M. Di Toro, H.E. Allen, R.F. Carbonaro, P.C. Chiu, Reduction of 3-Nitro-1,2,4-Triazol-5-One (NTO) by the Hematite-Aqueous Fe(II) Redox Couple, Environ. Sci. Technol. 54 (2020) 1219112201. https://doi.org/10.1021/acs.est.0c03872.

[235] E.J. Reardon, Anaerobic Corrosion of Granular Iron: Measurement and Interpretation of Hydrogen Evolution Rates, Environ. Sci. Technol. 29 (1995) 2936-2945. https://doi.org/10.1021/es00012a008.

[236] Y. Sun, J. Li, T. Huang, X. Guan, The influences of iron characteristics, operating conditions and solution chemistry on contaminants removal by zero-valent iron: A review, Water Res. 100 (2016) 277-295. https://doi.org/10.1016/j.watres.2016.05.031.

[237] A. Wieckowski, E. Chali, M. Szlarczyk, J. Sobkowski, the Behaviour of Iron Electrode in Co2- Electrochemical Study, Electrochim. Acta. 28 (1983) 1619-1626. http://www.sciencedirect.com/science/article/pii/0013468683852268.

[238] S.H. Joo, A.J. Feitz, T.D. Waite, Oxidative Degradation of the Carbothioate Herbicide, 
Molinate, Using Nanoscale Zero-Valent Iron, Environ. Sci. Technol. 38 (2004) 22422247. https://doi.org/10.1021/es035157g.

[239] A. Agrawal, P.G. Tratnyek, Reduction of Nitro Aromatic Compounds by Zero-Valent Iron Metal, Environ. Sci. Technol. 30 (1996) 153-160. https://doi.org/10.1021/es950211h.

[240] Y. Lü, J. Li, Y. Li, L. Liang, H. Dong, K. Chen, C. Yao, Z. Li, J. Li, X. Guan, The roles of pyrite for enhancing reductive removal of nitrobenzene by zero-valent iron, Appl. Catal. B Environ. 242 (2019) 9-18. https://doi.org/10.1016/j.apcatb.2018.09.086. 